\title{
总
}

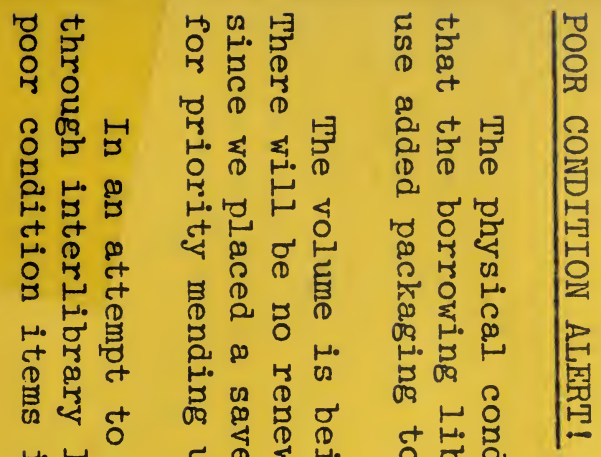

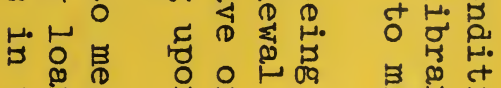

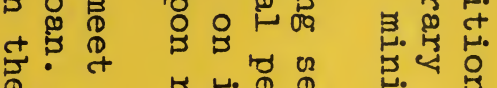
政

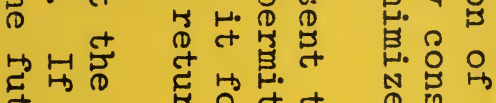

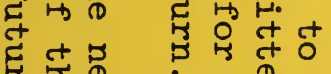

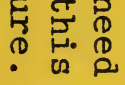
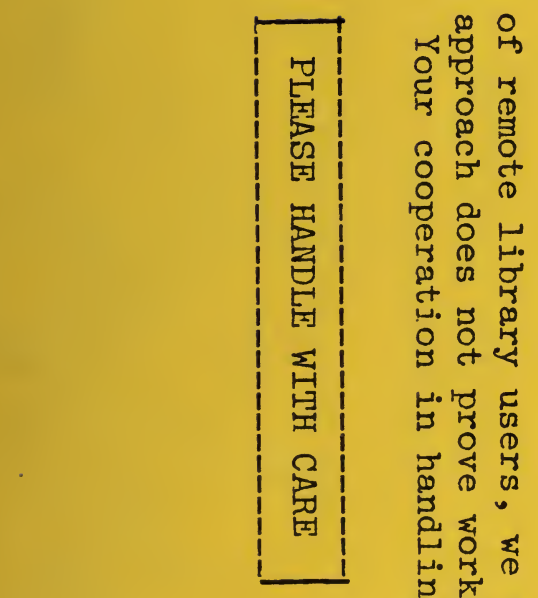

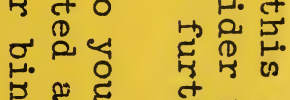
염 承尊

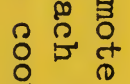
(o)

ก क थ t. 5 क 品骂高 H. म

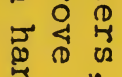
है $\sum^{\circ}$ ए ₹ू ₹ 5 म 呵 त5 出。最

동도옵

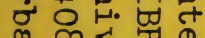
的

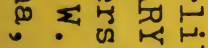

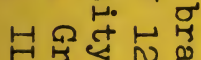

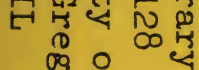

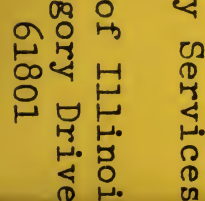

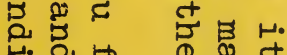

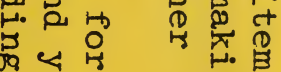
08 द म ह

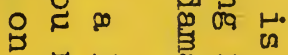

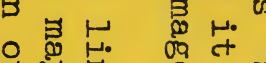
选 罗

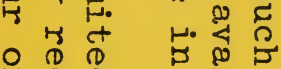
$B \Omega$ H. H N ש

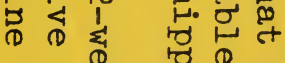

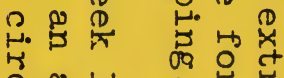
है है ct $B$ H. 0 0 त 10 D. H. H (2)

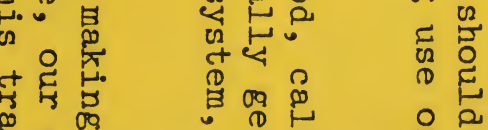
- 1 年 0

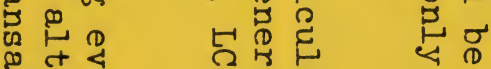

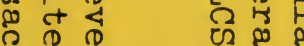
ค D D H C

i. 34

变。

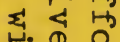
(1) $\mapsto \sum$ त ल का है

r. 맘ㅇ

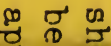
D 㭗 $H$ क D ct 展 ह. ๑ $\frac{D}{8}$ H. $\mapsto \infty$ w. D 1 


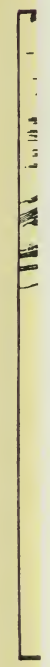

:

两

ปี

0

貝 \&

c a

(c)

म

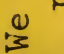

$+$

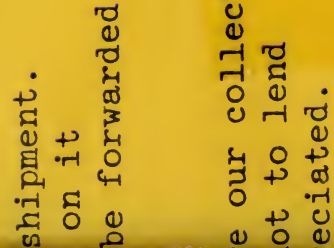

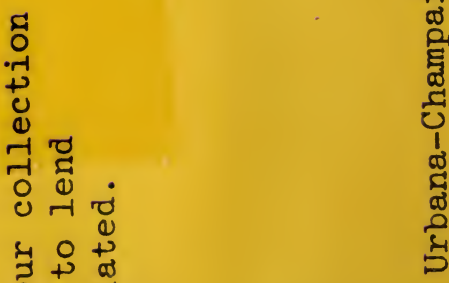

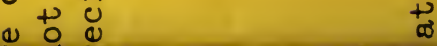


The person charging this material is responsible for its return to the or before the which it was withdred below.

Latest Date stamp books are reasons Theft, mutilation, and underlining may result in dismissal from the University.

To renew call Telephone Center,

UNIVERSITY OF ILLINOIS

MAR $05198 \%$

TES 24 BEL 1 Not 

Digitized by the Internet Archive in 2017 with funding from

University of Illinois Urbana-Champaign Alternates 


\footnotetext{
$\cos (x)$

of 714

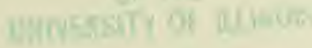




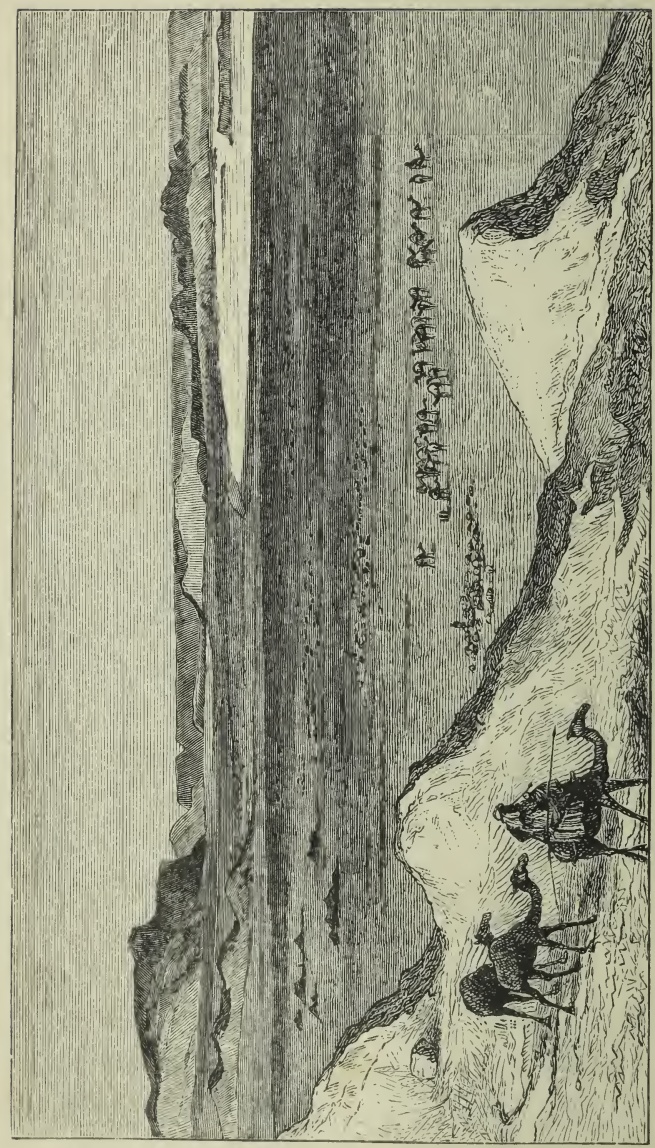

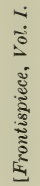

畗 


\title{
BEDOUIN TRIBES OF THE EUPHRATES.
}

\author{
BY \\ LADY ANNE BLUNT.
}

EDITED, WITH A PREFACE AND SONE ACCOUNT OF THE. ARABS AND THEIR HORSES,

By IV. S. B.

IN TTVO VOLUMES.

VOL. I.

WITII MAP A.VD SKETCHES BY THE AUTHOR.

LONDON :

JOHN MURRAY, ALBEMARLE STREET. 1879.

[All rights reserved.] 



$$
\begin{aligned}
& 915.3 \\
& \text { P6 ab } \\
& \text { Vil UNVERSTY OF ILIINOIS }
\end{aligned}
$$

Devicuted

To

HIS HIGHNESS

\title{
NEWAB BAHADOOR EKBAL OOD DOWLEII,
}

\author{
THE ILLUSTRIOUS DESCENDANT OF
}

THE PRINCES OF OUDE.

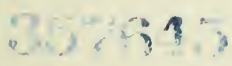





\section{PREFACE BY THE EDITOR.}

At the present moment, when all eyes are tumed towards the East, and when Asia, long forgotten by the rest of the world, seems about to reassert itself and take its old place in history, the following skctch of what is actually going on, in one of its most famous districts, should not be without interest to the English public.

The Euphrates Valley is familiar to every one by name, as a future high-road to India ; and we have it on the highest authority that its possession by a friendly power is vital to British interests. Schemes, too, are known to be on foot for rumning a railroad down it to the Persian Gulf, and advertisements have appeared, with maps on which such a line is already traced. Yet how few, even of those who write these things, have any accuaintance with the regions talked of or knowledge of the tribes which inhabit them!

The fact is, the Euphrates is more of a mystery 
to the general public than any river of equal importance in the old world. It has never been popularly described, and since the days of Xenophon, has hardly been described at all. With the exccption of Colonel Chesney, who was commissioned by William the Fourth, in 1835, to survey the river, and who has given us two bulky volumes of statistics. and an excellent chart as the results of his expedition, no traveller, as far as I am aware, has made a study of the district or narrated his adventures there in print. Till twenty years ago the Euphrates was a dangerous neighbourhood for Asiatics as well as Europeans. The Ánazeh were lords and masters of the river; and travellers were right in giving it a wide berth. But now the caravan road is a tolerably safe one, at least in the winter months; and there is no reason why some. enterprising Cook should not lead his "personally conducted parties" from Aleppo to Bagdad as easily as from Dan to Beersheba. Still, I think I am not mistaken when I say that the author of these volumes is the first bona ficle tourist who has taken the Euphrates road, and I make no apology for pullishing her experience of it.

With regard to the Author's further adventures, and the account given by her of the Bedouin tribes of Mesopotamia and the western deserts, I shall also, I 
think, be excused. 'The desert indeed has often been described, and most of the tribes here introduced have been visited before, but the circumstances of the present journey are new; and these volumes will be the first attempt at giving a comprehensive view of Desert life and Desert politics. No previous traveller has, as far as I am aware, visited the Independent Shammar in Mesopotamia or the Anazeh in the Hamícl.* The desert has been usually to Europeans a sort of Tom Tiddler's ground, where, instead of secking the tribes, it has been an object to slip by unseen. Circumstances have, in the present instance, changed the position; and the desert has been for a time the home of the traveller, as it is of the tribes themselves.

For my own share in this work (the chapters at the end of the second volume), I fear I have hardly so good a ples to urge. "For twenty years resident at Bagdad," or "for nine years engagea in missionary work in Syria," inscribed upon the title page, would, I know, enhance the value of what I have written; but this camnot be. Neither the

* Sir Henry Layard may perhaps have something to say to this, but his diaries are not yet published, while Dr. Porter, Canon Tristram, and Mr. Graham know only the tribes of the Syrian frontier. Mr. Palgrave passed through the desert as a townsman, and gives a townsman's account of it. The only living picture published, of Bedouin life and politics, is the "Récit de Fatalla," uoted by Lamartine, and by some accounted fabulous. 
author of the journal, nor I can lay claim to a more serious position towards the public than that of tourists, who have had the good fortune to see a little more than is generally seen, and to learn a few things more than are generally known. We left England with as little intention of instructing our fellow countrymen as travellers need have; and it was not until we saw that fortune had put us in the way of acquiring really valuable knowledge that we set ourselves seriously to work. At the same time I would remark that the value of labour done is not always in proportion to the time bestowed on it, nor even to the skill or courage of the performer. Chance often plays a considerable part in the most serious undertakings; and chance has favoured us here.

To begin with, our journey was made at an interesting moment, when the Bulgarian war was at its height, and when the strain on the resources of the Porte had so far relaxed the bonds of discipline in these outlying provinces, that the inhabitants were at their ease with us in speech and action. Then we had the singular good fortune to reap a whole harvest of information, which others had been preparing for years, in the very field we had chosen.'

Again, in our visit to the Bedouin tribes, circum- 
stances obliged us to go without escort, interpreters, or for the most part, guides, a position which, as it turned out, more than anything else predisposed those we came to see in our favour. There was no real danger in this, or real difficulty, but it was unusual; and the Bedouins fully appreciated the confidence shown in them. They became our friends. The Desert, last winter, like the rest of the world, was in confusion; and we were fortunate enough to be witnesses of a crisis in politics there, and of some episodes of a war. In these we could not help being interested; and the sympathy we felt in their troubles re-acted on our new friends and invited confidences which would hardly else have been made to strangers. We thus acquired, in a few weeks, more real knowledge of the Desert and its inhabitants than has often been amassed in as many years spent in the frontier towns of Syria.

This must be my excuse if, in the concluding chapters of this work, I liave ventured to speak somewhat ex cathedrâ, and if I have allowed what was originally only to have been a journal, to assume a more pretentious garb. These chapters I am alone responsible for. They are an attempt to epitomise the information collected in the Desert; and, though I am far from vouching for the entire accuracy of my sketch of life and manners, and still 
less of the stories I have repeated, I can at least affirm that I have taken little from books, and much from direct sources.

I have added what I think will interest many,a sketch of Arab horse breeding, with a genealogical table of the descent of the thoroughbred Arabian horse.

The choice of a proper system of spelling has been a great difficulty in the editing of this work. Neither the author nor I have any knowledge of written Arabic, nor, colloquially, of any Arabic but that of the Desert. It has, however, been repugnant to our taste to adopt a system entirely phonetic. "Ali" cannot be spent "Arlee," nor "Huseyn" "Hoosain," without one's eyes aching. On the other hand, few English readers would care to see the French "Ouady," or the German "Dschebel" for "Wady" and "Jebel." We have taken refuge, then, from greater evils in a modification of the old "lingua franca" spelling used by Galland, in his translation of the Arabian Nights. The vowels are written as in Italian, except in the case of the long $\hat{\imath}$, or before a double consonant, where they follow the English rule, the consonants also being as in English. We do not, however, pretend to accuracy, and wherever a conventional spelling exists, have allowed it to override our rules. The 
whole work, I must cxplain, has been written in haste-more haste than would be excusable, if new travels did not lure us back prematurely to the East.

In conclusion, and while protesting complete submission to the learned on all matters connected with Oriental lore, I take my stand against the merely untravelled critic in the words of the excellent Arabic proverb, which says: "The off forefoot of my donkey stands upon the centre of the earth. If you don't believe me, go and measure for yourself."

W. S. B.

CrabBet, October, 1878. 



\section{CONTENTS TO VOL. I.}

\section{CHAPTER I.}

Projects of travel-A visit to the Royal Geographical Society's rooms-We start for Aleppo-The voyage to Scanderoon-A bagman's tale of the Euphrates-Aleppo buttons-We land in Asia

\section{CHAPTER II.}

The Port of Scandernon-Relics of the Levant Company-We agree with a muleteer for conveyance to Aleppo-Beylan ponies--We cross the "Syrian Gates"-Murder of a muleteer-Turkish solliers-Sport on the Orontes-A night in a roadside khanSnowstorms-A dead horse-The village of Tokát and its inhabitants-A last day of misery-We arrive at Aleppo . .

\section{CHAPTER III.}

We are entertained by a wise man-Tales of my landlord-How Jedáin laughed at the Pasha's bearl, and made his friend Ahmet happy-The Ánazeh and their migrations-We are inspired with the idea of visiting the Bedouins-Seyd Ahmet and the JewsA sturly beggar . . . . . . . .

\section{CHAPTER IV.}

The Castle of Aleppo-Inscription relating to King DavidLegend of St. Zacharias and the Muédin-The prisons of Aleppo - Strange justice-Curro the Kurd-We give half-a-crown to a murderer, and offend public feeling . . . . . . 


\section{CHAPTER V.}

We buy horses, being resolvel to join the Ánazeh-Hagar-News from the Desert-Wars and rumours of wars-Jedáan at bayThe world is much "mixed up" -A chapter on politics .

\section{CHAPTER VI.}

We leave Aleppo-Wandering in the dark-An Arab village-The Desert-First view of the Euphrates-A Weldi camp-Zaptielis -A melancholy exile and a dish of francolins-Bivouacking by the river .

\section{CHAPTER VII.}

Lion district of the Euphrates-The Afuddli hunters--A Bedouin Barnum-The Kaimakam of Rakka-A wild ass-Sport in the tamarisk jungle-A wonderful horse-We arrive at Deyr . .

\section{CHAPTER VIII.}

Húsey'n Pasha's yaternal government-The Ottoman policy in the Desert_- "Divide et impera"-We are placed under surveillance, and hospitably thwarted in our design of visiting the Ánazeh-Deyr, the best market for pure Arabian horses-First talk of the Shammar-Their hero, Abd-ul-Kerim, his adventures and death-They threaten Deyr-A dishonest zaptieh-I fall into a well, and am rescued-We depart for Bagdad

\section{CHAPTER IX.}

A fresh start-We join a caravan bound for Bagdad-The son of a horse-'Turkish ladies on a journey-How to tether a fidgetty horse-Salahiyeh-An encampment of Agheyl-The Mudir of Abukamál-Wolves at night-Wild boars and others-The Boatswain's log-Palm groves-We arrive at Ana

\section{CHAPTER $\mathrm{X}$.}

A Bedouin foray-We converse with a ghost-Eingagement of Zénil Iga-We resolve to depart-The Kaimakam accompauies usEntertained by Sotámm-A Bedouin meal-News from home 


\section{CHAPTER XI.}

Modern Bagdad a poor place-Causes of its decay-The PlaguePAGE Midhat Pasha takes down its walls and lets in a delugeDr. Colville's view of the Bedouins-An Indian Prince-Akif Pasha's fortune-His stud-We buy asses and camels, and plan an evasion . . . . . . . . . .

\section{CHAPTER XII.}

The King of Oude and his "Desert-house "-We are sent away with gifts-The Mesopotamian desert-Pleasures of freedom-How to navigate the desert-Alarms and false alarms-Stalking a wolf

-We reach the Shammar $. \quad . \quad . \quad . \quad . \quad$.

\section{CHAPTER XIII.}

Ferhán's camp at Sherghát-His wives and sons-We diplomatiseWe start to cross Mesopotamia-Ismail on horseflesh-We are received by Smeyr-His account of Nejd, its rulers, and its horses

\section{CHAPTER XIV.}

The city and palace of $\mathrm{El} \mathrm{Haddr-We} \mathrm{are} \mathrm{mobbed} \mathrm{in} \mathrm{the} \mathrm{ruins-}$ Smeyr sends us on our way-We put our house in order and march westwards-Quarrel with Ismaïl-He leaves us-We discover salt lakes-A wade through the mud-A silly old manFaris at last . . . . . . . . . .

\section{CHAPTER XV.}

A gentleman of the desert and his mother, the Hatoun AmshehWell-behaved boys-Tellál-Faris goes out shooting-He swims the river-Swearing brotherhood-Rashid ibn Ali and the Sheykh of Samuga-The Yezidis-A raft on the KháburCamels swimming-Farewell to Faris-A gallop in to Deyr . 



\section{LIST OF ILLUSTRATIONS TO VOL. I.}

Plain of Melakir, axd River Euphrates . . Frontispice Citadel of Aleppo . . . . . . . . . $\quad \begin{array}{r}44 \\ 44\end{array}$

Saracenic Mill on the Euphimates . • . . . . . $\$ 9$

Miedin and Leaning MIosque . . . . . . . 131

A Wolf Course near Rumady , . . . . . . 174

Gä̈t Shamarar moving their Camp . . . . . . 255

Tellal starts on a Ghazú $\quad$ • . . . . . . 312

Map of the Eupirates Valley . . . At the end. 



\section{BEDOUIN TRIBES}

OF

\section{THE EUPHRATES.}

\section{CHAPTER I.}

" Wherein of antres vast and decarts idle, Rough quarries, rocks, and hills whose heads touch heaven, It was my hint to speak."

SHAKESPEARE.

Projects of travel-A visit to the Royal Gengraphical Society's rooms-We start for Aleppo-The voyage to Scanderoon-A bagman's tale of the Euphrates-Aleppo buttons-We land in Asia.

We left England on the 20th of November, 1877, with the intention of visiting Bagdad, and of spending the winter in some part of Asia, where we should find the climate good and the roads not too much frequented by Europeans. We had already visited more than one Arabic-speaking country, and had acquired a taste for Bedouin life and manners, with a little of the Arabic language, and we were anxious to improve our knowledge of these things by a more serious journey than any we had yet undertaken. There had, indeed, been a sort of progression in our travels, and we had been carried by them always further and further castwards, 
passing from Spain to Barbary, and from Barbary to Egypt, and thence to Syria, so that it was natural that the Euphrates valley and Mesopotamia should be chosen as the scene of cur next campaign.

When it had come to actually planning our journey, however, a number of difficulties at once began to show themselves. It was surprising how little information was to be got, even from the sources of geographical knowledge most respected in England. Bradshaw, whom we naturally consulted first, held out the golden hope of a regular line of land communications through Aleppo, while cn his map a railway route was freely traced; but it was more than doubtful whether all this could be taken literally, and whether the absence of dates and tariffis in the account did not point to the advertisement of some future scheme rather than to a statement of existing facts. At the Royal Geographical Society's rooms, to which we next turned, we were shown the maps and surveys made by Colonel Chesney in 1836, as the latest on the subject, no traveller connected with the Society having visited the Euphrates valley since that date, unless it might be Mr. Layard or Colonel Rawlinson.

We were recommended to take Constantinople on our way, and to consult the British Ambassador there, or, on second thoughts, we might call on Sir Henry himself, who was in London, and would be sure to pay all possible attention to our inquiries. From his long residence at Bagdad he would be the 
fittest person to advise us. Sir IIenry, to whom Wilfrid sent in his card, received him with courtesy and explained that the Euphrates Valley Railray had not yet been opened; that a land journey by that route was impracticable, owing to the hostile tribes which inhabited certain villages on the river; that the usual road to Bagdad lay through Diarbekr and Mosul, an interesting route, but passing too near the seat of war between Russia and Turkey to be recommended at the present moment. Sir Henry, all things considered, thought we could not do better than take the line of Turkish steamer's which made trips weekly from Aleppo to Bagdad. On these we should be safe and comfortable; Messrs. Lynch of Tower Street would give us all particulars, and Messrs. Cook could no doubt supply through tickets if desired. But, though we went away rather crestfallen at so simple an answer from our oracle, Messrs. Lynch could tell us nothing of any steamers but their own, which were on the Tigris not the Euphrates; nor could they suggest any shorter way of reaching Bagdad than by Bombay and the Persian Gulf. The only other person, who gave us information on the subject, was a gentleman who had travelled some years ago in Persia, and who had descended the Tigris from Mosul to Bagdad on a raft. He supposed that something similar might very likely be found on the Euphrates, and described the raft as a pleasant and commodious way of travelling, especially in hot 
weather, as the passengers sat for the most part with their feet in the water.

Besides this difficulty in the matter of correct information about the country we were going to, there were other obstacles, which at the time seemed even more serious. Kars had just fallen, and Armenia was supposed to be full of disbanded troops, flying from the seat of war. Osman Pasha was invested in Plevna, and every soldier and even every policeman in the Ottoman dominions had been hurried away to Constantinople for the defence of the capital. The newspapers were full of sensational tales of massacre, insurrection and disorder in the provinces, thus stripped of their protectors; and it was asserted that a general outburst of Mussulman fanaticism was imminent. English travellers, especially, might be expected to fare ill, for the feeling in Turkey was growing very bitter against England, who had "betrayed" her. At best the whole country was overrun by deserters from the army and by robbers, who were taking advantage of the disturbed times to set law and order at defiance. One paper asserted that a mutiny was hatching in India, another that the plague had appeared at Bagdad. It did not seem to be the proper moment for going to such a country.

Fortunately howerer we are too old travellers to be easily impressed by tales of lions and robbers, even supported, as they were in this instance, by 
the authority of special correspondents of the Times. Wilfrid declared that they were all nonsense, that Aleppo was not in Armonia, and that the last place a beaten army would retreat to would be the Syrian descrt; that if the plague existed at Bagdad so did the small-pox in London, and, finally, that we should "know all about it all in due time." So I was fain to be content with his assurance and to hope for the best; and, as it turned out, no moment could have been more favourable for the journey we were proposing. If the Turks had been victorious they might perhaps have grown insolent and dangerous, but in their misfortune they were only too happy to grasp any hand as a friend's. The conscription too for the army had taken all the riotous youths away from the country districts, fow but old men and women remaining, while, as for the absence of soldicrs and police, it was being hailed by all honest men in Syria as a pleasant respite from most of what made life irritating. Besides, no one in Europe can imagine how very slowly news travels in the East, nor how very suspiciously it is received even when at last it comes. We had finished our journey and were coming home long before the news of the Sultan's disasters was fully known in the desert. It was nevertheless with something like the solemnity of a last farewell that we embraced our friends and finally turned our faces to the East.

The first point for which we were to make 
(guided by the only definite piece of information we had acquired) was Aleppo, of which the seaport, Alexandretta or Scanderoon, may be reached from Marseilles by a line of steamers which makes its weokly tour of the Levant. I will not describe the twolve days of our voyage further than to notice the occasions on which we received intelligence of the mysterious land which lay before us. The captain, honest man, had navigated the Mediterranean for nearly forty years, but had never before heard of passengers landing at Alexandretta on their way to Bagdad. Aleppo he had heard of. It was a hundred miles inland, and there was no roal to it. Tourists gave it a wide berth on account of the button which bears its name, a strange and not rery agreeable malady, which attacks all who stay in or eren pass through the district. Of this he gave us a most alarming account, which I will repeat, deducting his exaggerations and premising only that we neither of us fell victims to its dangerous presence. The Aleppo button is a swelling which comes upon the face or hands or sometimes upon the feet and breaks into a boil. It lasts for six months or a year and then goes away. Except in the case of children or when aggravated by attempts at treatment, it leares hardly a scar, but, while it lasts, it is an annoying disfigurement. Any attempt to dive it away makes the evil worse, and nothing can be done beyond keeping the place untouched and raiting till it heals. Children suffer more severely 
than grown-up people, for it is difficult to keep them patient under the irritation for so long a time; and the conscquence is that nearly all the inhabitants of Alcppo are scarred decply either on the forehead or the cheek. It is not known what causes the button, whether the water or the air; no régime and no care seem able to elude it, neither is there any known remedy. Some ascribe it to the water of a certain stream at Aleppo, but Mosul, Bagdad and indeed all the towns of Upper Mesopotamia are subject to it, under different names and slightly different forms. At Bagdad it is called the "date mark." There are also tcrrible stories of travellers being attacked by it years after they had forgotten their danger. "Quelquefois après dix ans," said the ship's doctor, "le bouton vous vient." But enough of this not very pleasant subject.

At Smyrna a commis-voyageur from the Pays de Taud came on board and added his mite of information. He was "travelling in pills," he told us, and offered to take anything in cxchange for his wares, from a cargo of figs to an ostrich feather. He had seen much and suffered much in the cause of trade, having pushed his fortunes on one occasion so far as Abyssinia and the Blue Nile. IIo had travelled from Tiflis to Bagdad, and from Bagdad to Damascus with a cararan. It had cost lim, he said, £300 and a deal of trouble. He had never heard of any one visiting Bagdad for pleasure, and advised us, if we did go there, to do a little 
business in silk. It might help to pay our expenses. He had seen the Euphrates. It was a large river like the Rhone, but without steamers on it. The inhabitants were "de la canaille." He thought we should do better by spending the winter at Beyrout, where there was a French hotel and a café chantant.

More precise, if not more amusing, informants were a Pole in the Turkish service and a French engineer, on their way to Adana. One had bought horses at Deyr, a town on the Euphrates, and the other had taken part in an experimental voyage made by a Government steamer up the river four years before. Neither of these considered a land journey practicable, except by Diarbekr and Mosul, a five-weeks' march by caravan, and then by raft down the Tigris. Nobody went by the Euphrates, while the other was a post road. "Et fréquentée?" we inquired. "Oui, mais mal fréquentéc." It did not sound assuring.

But, on the 5th of December, our doubts and hesitations, if any we had, were brought to a sudden end by the arrival of the "Alphée" in the bay of Scanderoon; and in the early morning of that day we found ourselves fairly landed in Asia, with our troubles close before us. 


\section{CHAPTER II.}

"My father, jou must know, was originally a Turke, merchant."

Tristram Shandy.

The Port of Scanderoon-Relics of the Levant Company-We agree with a muleteer for conveyance to Aleppo-Beylan ponies-We cross the "Syrian Gates"-Murder of a muleteer - Turkish soldiers-Sport on the Orontes-A night in a roadside khan-Snowstorms-A dead horse-The village of Tokát and its inhabitants-A last day of misery-We arrive at Aleppo.

Alexhndretta, or Scanderoon as it was called in the days of the Levant Company, of which, if I conjecture rightly, the elder Shandy must have been a member, is now little more than a collection of hovels by the sea-shore, surrounded by a marsh and backed by the steep slopes of the Amanus hills. Its position, in a land-locked bay possessing good anchorage, the only good anchorage on the Syrian coast, and at the far corner of the Mediterranean where Asia Ninor and Syria meet, made it a port of great importance once; and for many years it was the chief station of the English trade with India. But the discovery of the Cape of Good Hope brought Seanderoon its first misfortunes, and the orerland route through Egypt its death blow. It is fifty years now since the Levant Company wound 
up its affairs and disappeared (the East India Company, its imitator and rival, has done so since); and nothing remains in token of its former prosperity in this its principal seaport but a pile of ruins, its "Commercial House," and the graves of the many Englishmen who lived, made money and died there. It was certainly a melancholy sight, this commercial house, the haunt of bats and frogs; for the marsh had already reclaimed its prey, and the court yard was now some inches under water. It gave one the ague to look at it. Scanderoon, at the present day, boasts neither inn nor mosque, and its bazaar was burnt to the ground some weeks before we arrived; but it is still the nearest seaport for the Bagdad caravans, and if ever the Euphrates railway is more than a project, may again become the rival of Alexandria. The marsh, they say, might easily be drained, and with it the fevers now common would disappear. The town enjoys about the most beautiful view in the world across the bay to the Caramanian hills, just now white with snow.*

We were lodged comfortably at the Vice-Consulate by M. Catoni, a Corsican by birth, and lately appointed British Vice-Consul, as he had previously been Swedish and Greek. English travellers are rare at Alexandretta, and we were most hospitably entertained by him, all trouble being taken off our hands in the matter of arrangements for our journey to Aleppo. Hadji Mahmoud, a respectable carrier

* This account was written before the annexation of Cyprus. 
of that town, was sent for, and engaged to convey us and our baggage, for four hundred piastres (£3 $4 s$.), and see us safely to our destination. He was a good-looking man, as most of the Syrians are, handsomely dressed in a striped turban, a striped jacket and striped trowsers, with a pair of new red moroceo boots, of which he seemed not a little proud. Three mules would be enough for our baggage, and he would provide horses for ourselves. It seemed a reasonable sum for the four days' journey, as we were in Decomber, and the roads might be expected to be bad. Not that there was any sign of winter yet where we were. Alexandretta with its blue sea and cloudless sky looked the home of an eternal summer; and only the snow, a hundred miles away on the Taurus mountains, showed that winter had begun. We were to take a provision of bread for the road, as none was to be had there; but we should find, it seemed, eggs, and the traditional fowl which waits for travellers in every quarter of the globe. The consular cook went with me to market, and with his assistance I purchased thirty of the flat Arab loares, just as they were turned out of the oven, some salt, pepper, a flask of oil, a frying-pan and a string of onions. With bread and onions one may travel far.

Thus provided, and with a good bag of beshlites, the base coin of Syria, for immediate needs, and spirits rising at the prospect of fine weather and the new country open before us, we rode out at an carly 
hour on the 6th of December, through the swampy streets of Scanderoon, across the marsh and by a rising road towards what are called the Syrian Gates, the mountain pass of Aleppo. It was a warm morning, and we could have almost been persuaded to leave our heary cloaks behind us but for an appearance of wind far out at sea. The marsh was full of kingfishers, sitting on the telegraph wires, and now and then pouncing with a splash into the water. Our ponies, ragged little beasts, stepped out at a good pace, and the bells of the leading mule jingled merrily. There was a sense of expectation in the air with the thought that we were at last fairly on our road through Asia, and that mysterious promise of adventure which makes the first day of a journey only less delightful than the last. Our road now left the causervay, which had crossed the marsh, and wound among the ravines and watercourses of the hill side. We had plenty of fellow travellers, riders on mules, horses, donkeys, and camels, and people on foot, (for this is perhaps the greatest high road in A.sia). But they passed us without remark or salutation, and only one or two exchanged a nod with Mahmoud. As we turned the shoulder of the hill we were met by a violent wind which nearly blew us back over our ponies' tails, and sufficiently explained the "white horses" we had seen out at sea, and the enormous capotes into which Mahmoud and his assistant Kasim had built themselves. Two 
hours' struggle, however, brought us to a place of shelter and a halt in the town of Beylan,* the first station on our road, where the consular carass, who had hitherto led the way on a good-looking white horse with three shoes off and one shoe on, made his salaam and left us at the khan. The khan was a respectable place enough, with a row of empty rooms on an upper floor, bescribbled with the names of sailors and Levantine shopkeepers, mostly French, who had stopped there on their way to or from Antioch; and there we waited half an hour while a kháwaji (coffee seller) fried us some eggs ancl brought coffee from his shop hard by.

We were now fairly left to our own resources; and these, for the moment, appeared very slender. The few words of Arabic we had picked up in Algeria and in Egypt would not at all pass current with Hadji Mahmoud and his fellows, good honest Syrians, quite unused to guessing the meaning of words in an unknown tongue; for we were far away from the region of dragomans, Jew pedlers, and the nimble-tongued donkey boys, who haunt the steps of tourists in those parts of the East which they have made their own. Here all thirgs were as purely Asiatic as if we had been at ilerv $\mathrm{Or}^{\circ}$ Ispahán. Hadji Mahmond however was goodnatured if not quick-witted; and we had the whole stock of our patience yet untouched and were prepared to live as we could till better times should be.

- Beylán, a corruption of the ancient Pylae, or Gates of Syria. 
So we readily consented when he seemed anxious not to lose time and begged us to go on and overtake the mules, which, having had some minutes start of us, were already beyond the crest of the pass. It was blowing a hurricane there, and was bitterly cold. The view overlooking the lake and marshes of the Orontes far away towards Antioch was very beautiful, and we could see where Antioch lay, its position being marked by a pointed hill and the white line of the river to our right.

We had now passed the highest ground and soon began to descend towards the plain, which cannot be many hundred feet above the sea level; but the fall of the hill is gentler here than on the western side. Coming down we met four or fire hundred men on the march from Aleppo,-- soldiers on their way to the war; but very few were in uniform, and at least thirty of them wore wooden handeufis shaped like stocks, and fastened in the same way. These, it turned out, were deserters under arrest. Fifteen hundred, we afterwards learned, had left Aleppo, but two-thirds had managed to desert on the road by paying a mejidie each (four shillings) to their major, and when recaptured, as some of them were later, they had complained loudly of the money not being restored. The soldiers we saw were a fine-looking set of men, in good condition, but in depressed spirits; leaving their homes, poor creatures, for the doubtful glories of war. They talked little either to each other or to us, and only 
a few stragglers inquired how far it was on to Beylan. I was very sorry for the poor fellows, as theirs is a hard lot,-no pay, little food, and a forlorn chance of ever returning. They must hare just heard too the news of the fall of Kars.

We had hardly passed the last soldier when we came to a grove of olive trees. Here about three weeks ago a muleteer was murdered by some Turcomans of Mount Amanus. He was accompanying a rich merchant of Aleppo, who, being an invalid, travelled in a litter. The Turcomans stopped his caravan and demanded $£ 4,000$, the exact sum he had in specie concealed in the litter, but the merchant showed them only bills of exchange, which he told them represented the money. These the robbers would not take, and, turning upon the muleteer, their accomplice, they called him a false friend and shot him through the head. The merchant arrived safely at Aleppo with both his gold and his bills.

The sun was setting as we reached the group of mud hovels where we were to pass the night, and which go by the name of Diarbekrli Khan. I confess that my spirits sank as I peeped into one after another of these most uninviting dwellings; but our tents were in England, and the wind was chilly, and there was nothing else to be done: so we chose the biggest hovel, or the emptiest (for there were ten or a dozen men in each), and made oursolves as comfortable as we could with a barri- 
cade of luggage round the space allotted us on the platform where travellers sleep. The construction of these khans is simple,-four mud walls and a roof of thatch, with a post in the centre, to which a lamp is hung; for floor, the natural earth; for fire-place, a hole in the ground; and for beds, the raised platform I have spoken of, which is exactly the same as that which hounds have to sleep on in their kennels in England. The arrangement is not so bad in practice, however, as it sounds. On the platform you are more or less out of the reach of things crawling and things hopping, and it is wide enough for you to make your bed on it in its breadth. Once there, you cannot be trodden on by accident, or jostled by the people crowding round the fire.

We were tired with our first day's ride, and as soon as we had spread our quilts, slept soundly for an hour or more, in spite of the noise and of the strangeness of our fellow lodgers, who after all, peasants as they were, had better manners than to interfere with us in any way, and who, when we woke up, let us have our share of the fire to warm our bread at, as they had already let us have more than our share of the platform. Only there seemed no prospect of anything to eat beyond what we had brought with us. Everybody munched his bread as we did, apparently well satisfied with that for his evening meal. A little coffee was made and handed round, and about midnight the chuckle of 
cri. II.] A Night in a Roadside Khan.

a fowl announced that dinner was being thought of. But we were then long past caring, and in the land of dreams again. A boy with the whooping-cough on one side of me, and the loud snoring of a muleteer were the last sounds I heard that night. Then the khan and all in it were still, - all but the cats, which prowled about till morning, creeping stealthily round us and snuffing close to our faces.

At cockcrow Hadji Mahmoud aroused the house, declaring that it was time to be off, as we harl a nine hours' ride before us, and long before you could distinguish, as Mahomedans say, a white thread from a black one, everybody had crowded back to the fire to warm their hands, beds had been rolled up, and boots put on.

We were the last to move; and when the baggage, with Hadji Mahmoud, had been despatched, and the other travellers gone, we had a few quiet minutes to ourselves at the fire, where the khanji brought us coffee and his bill. We made him very happy with three beshliks (half-acrown), and so our night's adventures ended.

It had rained since the day before, and the wind outside the hut was chilly. I had a headache; and we both felt tired and sorry for ourselves. But there was no help for it now; and we mounted and rode away, following the edge of the hills in a northerly direction. Our road had now descended almost to the plain; and presently a great marsh appeared to our right, its presence announced by swarms of VOI. I. 
waterfowl, which rose as we came near it--snipes. and plovers and herons, and now and then a flight of ducks. I noticed sereral pochards and teal, just as on our ponds at home; and especially some very handsome red and white ducks, which must have been sheldrakes. This marsh is crossed by an ancient causeway, probably of Roman construction; and along it we passed, turning sharply to the right, and eventually coming to a high bridge over the river Orontes. Here Wilfrid dismounted, anxious: not to lose so good an opportunity of securing us against another dinnerless evening, and was lucky enough to stop a couple of shovellers as they were flying up the river. They fell, too, most fortunately, exactly on the bridge we were crossing, or we could not have picked them up. Then Kasim begged for some coots which were dabbling about close by, and a family double shot brought four to the bag. Encouraged by this, we tried a drive, but it was unsuccessful; and, the weather seeming to threaten serious mischief, we had to be content with what we had got, and make the best of our way to get in before the rain. We must have passed nearly a thousand camels in the course of the day, some driven by Bedouins (probably Agheyl), some by townspeople, and most of them, I fancy, carrying corn for the Gorernment. Some were certainly so employed, for one large cararan was headed by an immense camel bearing the Turkish flag and escorted by soldiers. These were, I think, the finest. 
camels I ever saw, and in splendid condition. We got to Afrín just in time, for the rain was beginning to fall, and before night it came down in torrents. We were lucky besides in being able to cross the ford there that evening, for sometimes caravans are delayed for days by the flooding of the small muddy river, a branch of the Orontes, over which there is no bridge or ferry, and camels are stopped after rain altogether by the marshes.

The khan at Afrín was what they call in Arabic the "brother" of the last, but much more crowded. Amongst others round the fire were some soldiers, who looked at our map and asked us about the war. They seemed intelligent, but with the vaguest ideas: of geography, and they asked particularly about the fall of Kars. We told them the news was true, but that Osman was doing well at Plevna. The little old khanji came up to us during this discourse, and begged us, in French, not to say that things were less than right with the army in Armenia, as the soldiers would be angry. "I am a Christian," ho said, "and am glad the Turks are beaten, but they don't like it." I made him cook the ducks for our" supper, and fry us some onions. The soldier's sat talking politics all the evening, and almost came to blows; but rowdiness in these countries has not the assistance of drink, and seldom leads to harm. Not but what I suspect Hadji Mahmoud of a taste for arrack, or he would not have such a glittering eye, 
or be subject to such sudden fits of cheerfulness without apparent reason. I hope I do him wrong.

We started on our third day's journey, fortified, in all the coats and cloaks we possessed, against the rain, which was falling heavily, and a bitter wind, which was blowing from the north. Our road was one of the most cheerless that can be imagined; a track of rusty mud, winding over a wilderness of low, stony hills, on the crests of which the wind cut keenly as a knife, changing the rain to sleet. In the hollows there was an occasional lull as we laboured, up to our horses' hocks, across what had once been fields, the little beasts going gamely on, in spite of every hideous combination of rock and mud which could bring a creature to its knees. Walking was impossible, though Wilfrid tried it more than once; for the rocks were as slippery as glass, and it was all he could do to keep his footing. My feet were aching with the cold in a more excruciating way than I ever remember to have felt, and my finger's were numbed to insensibility, though I kept them well in my pockets. We sat like patient bundles on our horses, letting them choose their own road and go their own pace, with the reins upon their necks, in trust of Providence and of that excellent good sense it had endowed them with. I think a fall any time that day would have been the end of us, and that neither horse nor rider would have risen 
out of the slough again. Once we passed a dead horse with its owner, an old man, standing orer it, the picture of despair-but it was the retreat from Moscow, and each had to shift for himself. There was no stopping. The camel caravans had already given it up as a bad job, and we occasionally passed a hundred or so of these beasts, grazing in sheltered places, while their masters waited snugly enough under their bits of black tenting, and with the loads piled round them to make a barrier against the wind. It was a wretched ride, and we did not stop for an instant all day long; nor were we able to derive the smallest satisfaction from the thought that we were crossing the battlefield on which Zenobia was defeated by Aurelian, and that the ruined towns, which stood every here and there upon a crest of hill, had been destroyed by Joab in the reign of King David. The whole country seemed to have been populous once; and there were thousands of acres of excellent land lying umploughed there for centuries. Now all was deserted. Once or twice we passed a village, and it was evident that the little plain on which it stood had been under cultivation lately; but this year, owing no doubt to the war and the consequent loss of labour, not a twentieth part had been furrowed. The thistles had it all their own way.

The tenure of land in Turkey is peculiar. Tho soil belongs to the Sultan, who receives rent in the form of a land tax, ten per cent. on the gross pro- 
duce, from any one who chooses to plough it. The act of doing so gives a right of occupation to the farmer, which only lapses if he allows the land to lie fallow during three years. Should he do this, his neighbours may scramble for possession; but, in ordinary circumstances, the tenancy is perpetual. These tenures are bought and sold, just as though they were frechold, or as we buy and sell leaseholds in London. But I fancy there is rery little competition, and that most land in the province of Aleppo has no marketable value whaterer. A. Syrian we met at Aleppo informed us that the best building ground in the city was to be bought for fiftecn piastres the pik, or 1s. 3d. the foot; and that, just outside the town, it might be had for one piastre; in the country, for nothing at all. We hear too that sereral Europeans have tried the experiment of occupying waste land, but none with success. The Government discourages all such schemes. Yet there must be millions of acres of good land in Syria, well watered and in a healthy climate, only waiting to be used.

In gloomy speculations on the miseries of mankind, and the particular misery of having frozen feet, and hands which were long past feeling pain, our day passed by. At last the little town of Tokat came in sight; and we were floundering on its parement in the delightful certainty of shelter, if not of food. Mahmoud had friends at Tokát, and took us, not to the khan, but to their house. It was a square 
building of hewn stone, and apparently of great antiquity, an exact cube of fifteen feet, without window or opening of any sort but the door, which was two steps down from the level of the strect. The inside was vaulted with perfect regularity, and had been freshly whitewashed to an appearance of neatness and comfort we did not at all expect. There was no flooring but the rock; but this was perfectly level, and there were nice clean mats spread over half of it. Four huge sepulchral chests, containing corm, occupied the corners; and a sarcophagus, as linen cupboard, stood in an arched recess opposite the door. On one side was a fire-place, on the other a thing looking like a dove-cote, apparently of earthenware, and designed, as pigeon-holes are in public offices, for holding rubbish. The whole place, cupboards, pigeonholes, sarcophagus and all, was beautifully white, and looking as if cut out of one picce. Indeed it was an extremely pretty room, off the floor of which you might, as they say, have eaten your dinner; and that is what we were soon doing. A tidy woman with a little boy received us, and welcomed Mahmoud with a torrent of amiable inquiries. She brought a brasier with a live ember in it, and lit a fire of sweet-smelling twigs, at which we thawed our hands, and helped us to take off our wet things and lay out our beds upon the floor. But, alas, there was no coffee, nor anything to eat but half a dozen eggs, with our bread and the remains of a 
fowl from Afrín. But, all the same, it was a delightful meal, and there was a jar of water in a corner with a tin cup where we could drink.

Our hostess was a good honest body as one would wish to meet, who spent her time spimning cotton with an old-fashioned wheel and rocking the child's cradle with her foot, like any English labourer's wife of fifty years ago. On little Akhmet, or as his mother called him Akhmet Beg, she spent a deal of affection, and everybody who came into the house was called upon to do his share of nursing and amusing. Mahmoud was made comfortable with a dish of eggs and a pile of quilts on the floor, and we in our corner did our best to get warm. But it was terribly cold, in spite of the brasier, and we were chilled to the bones. We tried to converse with Aclóuba, as the woman was called; but her Arabic and ours did not agree, and we could not get far. Indeed we found our few words of the Egyptian dialect quite unintelligible, and we had to begin everything afresh. The accent and eren the words were all changed from those of Cairo. This was very vexatious. Adóuba went on spimming while there was light to see; the spinning-wheel was like a drum, and to the droning sound of it I went to sleep at dusk. I woke up again just before the lamp was put out, and saw that the husband, Halíl, and his wife had rolled themselves up in a heap by Akhmet's cradle on the fire-place side of the room. Hadji Mahmoud lay comfortably snoring, 
a shapeless lump of quilts, on the arch or sarcophagus side. We had possession of the space commanded by the row of pigeon-holes, really the best part of the room; but we could not sleep for the cold, and remained shivering. Outside, the rain pattered and the wind blew all night.

I hurry over the remainder of our road, as in fact we did the next day, chasing the minarets of Aleppo, which we had caught sight of five hours before reaching the city. It was still raining heavily as, at the turn of a hill, we suddenly came upon Aleppo with its border of trees and gardens, and its fortress, towers and minarets, making one of the most agreeable sights in the world. We did not stop to admire, but, with a crowd of other travellers and mules and horses and asses, hurried into the city, and were soon at the lokanda door and at the end of our troubles. Well,-as Bewick says, "Good times and bad times and all times get over." 


\section{CHAPTER III.}

"Set you down this, that in Aleppo once

SHAKESPEARE.

We are entertained by a wise man-Tales of my landlord-How Jedáan laughed at the Pasha's beard, and made his friend Ahmet happy-The Anazeh and their migrations-We are inspired with the idea of visiting the Bedouins-Seyd Ahmet and the Jews-A sturdy beggar.

I sHaLl always consider it a fortunate circumstance, little as we thought it to be so at the time, that the severe storms, for which the winter of 1877-78 will long be remembered in Syria, held us for a whole month weather-bound at Aleppo. Not that the town itself particularly interested us, though it is an excellent specimen of a purely Oriental city, but because the delay gave us time to look about us, and to get some idea of the country we were going to, and of the manners and customs of its inhabitants, all of which information was, later on, of the greatest possible service to us.

We had hardly been more than a few hours at our lokanda, a poor cooped-up place with a courtyard like a well, before Mr. S., the British Consul, 
to whom we had letters, called, in company with his amiable wife, and hospitably compelled us to exchange our dismal lodgings for his own comfortable house. The Consulate, though partly ruined by an earthquake five years ago, is an attractive building, set on solid stone arches across a river. There is a pleasant sound of water underneath the rooms, and a pleasant look-out over market gardens from the windows, just the sort of place Orientals choose, who have more love of trees and rumning water than fear of damp. The house was a convent once, and still has a cloistral look. There is a grotto in the garden where the nuns used to be buried, with graves cut in the rock containing bones. I found part of a skull there and some ribs, lying in one of them uncovered,-but these things are common in the East. Close by, like a fortress of hewn stone, stands a mill; and there are a few willows and mulberry trees which, with the water, attract crowds of holiday makers on Friday afternoons, making the river bank a country imitation of the Sweet Waters at Stamboul.

Here we found, besides the bodily comforts of food and shelter, ample entertaimment for our minds, hungry for knowledge of the lands which lay before us. Our host, a man of sixty, with nearly thirty years' experience of Eastern life, was in truth an authority on all matters comnected with Turkey, and, what interested us far more, the Desert and its strange inhabitants. Here, for the first time 
we learned the truth about the Euphrates valley, and Mesopotamia, and the caravan roads practicable and impracticable for travellers. Mr. S. had been himself, in his younger days, a bold and enthusiastic explorer of the desert. He had made friends with the Bedouins, and passed among the tribes almost as one of themselves. In him we found at last an intelligent sympathiser with our love of adventure, which the rest of our world had been at such pains to discourage ; and we owe it to him that our vague scheme, of spending the winter in the neighbourhood of Bagdad, took definite shape, and resolved itself into the plan of which this book is the result.

It was, as may be imagined, a delightful surprise to us to find thus, at the very threshold of the East, so excellent an expounder of the Asian mystery; and, when the north wind blew day after day more furiously, and the rain changed to snow, and reports reached us of caravans brought to a standstill in the mud or snowed up in the mountains, we were easily persuaded to stay on, listening to the "tales of our landlord," and always with increasing interest. These turned, as I have said, principally on Bedouin life and manners, things at which we had hitherto looked with the half contemptuous ignorance with which the European world regards them, but which we now found set before us under a new and fascinating light.

The Euphrates ralley, we discovered, was neither an absolutely impracticable route nor a mere every- 
day excursion, to be undertaken with a light heart and a handful of Cook's coupons. No line of steamers ran as yet on the river, though one had been projected and a Government boat had occasionally made the voyage and even taken passengers on board. There was, however, a caravan road, more or less protected by a series of small forts and patrols of soldiers, which in winter time was used by the more adventurous merchants of Bagdad and Aleppo for the purposes of trade. Down this we should in ordinary times run no serious risk in travelling; and, even now, though the war had stripped the forts of their garrisons, our host was of opinion that we might safely venture. The only risk to which we should be exposed, would be that of encountering roving parties of Bedouins; and these $\mathrm{Mr}$. S. represented to us in a less alarming light than they are generally shown.

The politics of the deserts bordering the Euphrates he explained to us thus:-The left bank of the river had from time immemorial been inhabited by the Shammar, a numerous and powerful clan of pure Bedouins, who exacted tribute from the tribes of Mesopotamia, while the right bank was tyrannised in like manner by the Ánazeh, a still more numerous and more powerful clan, which held the whole of what is called the Syrian desert, from Aleppo in the north to Nejd in the far south. These two great tribes were constantly at war, and marauding parties from either side occasionally crossed the 
river to plunder and ravage the enemy's territory. Travellers, who should come across such a party, would run a certain risk of being plundered, though there was no fear of their suffering personal violence. The valley itself was inhabited by a number of peaceable shepherd tribes, tributary to the fighting tribes; and from these there was nothing to fear. About twenty years ago, moreover, the caravan road had been occupied by the Turks; and these small tribes were now to a certain extent under Government protection. Of the Shammar, and the country east of the river, our host knew nothing, but with the Ánazeh he was on terms of familiarity, and, from the fact of his having often rendered them little services with the Government, had claims upon their good will. To them he promised to give us such introductions as should secure us from harm.

The Consul was an excellent narrator ; and some of his stories seemed as though fresh from his countryman Walter Scott. Among others we were struck by those relating to a certain Jedáan, one of the Ánazeh Sheykhs, who at the present moment figured as the Rob Roy of the Desert. This Jedáan, it appeared, was to a certain extent a soldier of fortune, - that is to say, he did not belong to any of the "noble" families of the Ánazeh, but had worked his way up from a rather obscure position, by his military skill and courage alone, to the rank of supreme leader of the most powerful section of the 
Ánazeh. A few tales of this hero may not be out of place here, and will serve as an introduction to him and his fellows, when they come in their turn in person on our stage. The occasion on which the Consul made his acquaintance with Jedáan was as follows:-In 1857, when Ásmeh Pasha was military commander of Aleppo, being a man of some energy of character and desirous of distinction, he made an expedition against the Fedáan tribe of Ánazeh, of which Jedáan is Sheykh. Its head-quarters at that time were on the plain of Melakh, by the Euphrates. Mr. S. was asked to join the expedition, as the Pasha wished to have a European for witness of his skill. Ásmeh himself commanded the party, which consisted of two battalions of rifles, two squadrons of cavalry, and four guns. They had about sixty miles to march, and bivouacked the first night on the hill above Jabúl. There was no moon, and the sky was cloudy, and in the morning it was discovered that the mules, which were used for the artillery, had disappeared. Cavalry horses were however impressed into the service of the guns, and a second march brought the Turks to within ton miles of the plain, where they expected to meet their enemies. But again, and in spite of extra watching, a panic occurred among the animals at night, and many were missing next day. Ásmeh Pasha was exceedingly angry at this, but continued his march undaunted, arriving early at the edge 
[CH. III.

of the cliffs which overhang the valley of the Euphrates. In the plain below a camp was visible, with a tremendous stir going on in it. It was the Ánazeh hurriedly crossing the river. They had fancied that the troops would have gone back, after losing their horses, and were now retreating with all speed. Only a herd of some five thousand camels remained undefended. These the Pasha determined on securing.

The army was accordingly marched down to a point on the plain where a little tell, or mound, offered a strategical position on which to place the guns; and a party of cavalry was sent to intercept the camels from a possible retreat in the direction of the Euphrates. The manœurre was well executed and the camels surrounded; but, while all attention was being directed towards these animals, a party of eight horsemen appeared swimming the rirer, which was then low ; and, before the lieutenant in command was aware of his danger, the leader of these had galloped up and run him through with a lance. The soldiers, scattered and taken by surprise, gave way; and the whole party, soldiers and Bedouins, came straight towards the mound, where the main body of infantry and the guns were posted. The Pasha ordered the artillerymen to fire, and himself pointed one of the guns, but the result of the discharge was only that one of his own men was brought to the ground. The noise, moreover, of the guns occasioned a stampede among the 
camels, who went off in a body, trampling down all that were between them and the river, while the Bedouins, calling out as they do "haú-ó-hać-ó," led the way and succeeded in taking the whole herd across. The leader of this successful rescue was Jedáan, whose brilliant exploit ended the expedition. Ásmeh Pasha returned to Aleppo without other trophy of his valour than the loss of two men.

This incident gave Mr. S. a great curiosity to see more of the hero of the adventure, and circumstances favoured his wish. Not many weeks later he received a message from Jedáan, begging him to intercede with the Pasha, as he was desirous of peace and of the privilege of trading with the town;-at least, he urged, the Consul might give him a safe conduct, when he came to make terms at Aleppo. Such an appeal to a foreign Consul is not an unusual proceeding with the Bedouins, who are always alternating between the pleasures of war and the advantages of peace, and who are afraid of negotiating straight with the Turks, on account of their notorious ill faith. Mr. S., however, though wishing to see Jedáan, could not guarantee his safety in Aleppo, and declined to give him the safe conduct. But either the letter was misinterpreted, or Jedáan would not be refused; so one morning without further announcement the Sheykh appeared at the Consulate. He was asked what brought him there. "Your letter," was the answer, "and I claim your protection." The case 
required some consideration, but in the end it was: decided that though he could not remain under British protection, protection to return should be granted him. The Consul bade Jedáan be off, if he valued his life, but, ordering his own horses to be saddled, mounted with him and, escorted by the Consular cavasses, rode with him through the town. In such company Jedáan was safe from the police, and once outside was too well mounted to be in any langer. At a mile from the gate they parted. But Jedáan, with a feeling of gratitude not common among the Bedouins, or in the expectation, if you will, of future favours, did not forget the benefit, and has remained the Consul's faithful friend through life.

Mr. S. returned the Sheykh's visit soon afterwards, when the usual bribe had secured to the latter a deed of amnesty; and the first thing Jedáan took him to see in the Fedáan camp was a troop of artillery horses in their equipments, his trophy from the war.

Jedáan since then has been sometimes outlawed, sometimes amnestied by the Gorernment, but he has never put his neck again in jeopardy by entering a town. He is now the leading warrior of the Sebáa, who have accepted him as their military chief, and he has the reputation of being the longest headed of all the Ánazeh Sheyhls.

On another occasion, tired of war and listening to the intrigues which the Gorernment is always at 
pains to work among the tribes, the Fedáan agreed to acknowledge another Sheykh in Jedáan's place, a cousin of his own and recommended by the Pasha. Jedáan found himself deserted by his followers, but would not accept the deposition they had voted. He rode alone into his rival's camp, met him at his tent door, and killed him in the presence of all his men. Nobody after this disputed his right to be leader.

At the time when we first heard of him, he was carrying on war with the Roála, the most powerful tribe of the Ánazeh, and every day brought in news of his valiant deeds. Of these I will give an account later, when I come to speak of the desert feuds and politics in which we came to be mixed up; but I have mentioned these incidents as an explanation of the interest which this picturesque outlaw inspired in us. What wonder that it was soon our principal desire to make his acquaintance?

Another of the desert heroes was Akhmet Beg. He was Sheykh of the Moáli, a tribe founded according to tradition in the eighth century, by Theodora, wife of the Emperor Justinian the Second, in honour of a son of one of the Ommiade. Caliphs of Damascus, to whom she was attached.*

* Justinian the Second fled " to the horde of the Chozars, who pitched their tents between the Tanaïs and Borysthenes. Tho Khan entertained with pity and respect the royal suppliant; Phanagoria, orice an opulent city, on the $\Lambda$ siatic side of the lake Mrotis, was assigned for his residence, and every Roman prejudice was stifled in his marriage with the sister of the barbarian, 
The tribe originally consisted of slaves, bought by her, and from this circumstance is known as the Moáli, or "property" tribe, and as such are held in but moderate estimation by the pure Arabs. But their Sheykhs, being descended from the Caliphs, hold a great position, and are always given the title of Beg, unknown, except in this instance, in the desert. Akhmet was a man of herculean strength and, standing over six feet high, was considered a giant by his fellows. He was handsome and brave, and we have often since heard him spoken of as the "properest man" ever seen among the Bedouins. "Ah," they say, "you should have seen Akhmet Moáli" (for the name of the tribe is often added to that of the individual). He had a passion for "great horses," or rather for great mares to suit his size and weight. The appearance of him alone would put thirty men to flight. The shaft of his spear too was sixteen feet long, "like a weaver's beam." He was covered with the scars of old wounds, and had sworn not to "die in bed like a gentleman of Aleppo." He was moreover an honest and an honourable man, unlike Jedáan, who was always a "wild fellow." On one occasion he had rescued Mr. S. and his son from a band of Shammar by whom they were surrounded. The sudden charge of Akhmet on his great white mare,

who seems, however, from the name of Theodora, to have received the sacrament of baptism." Gibbon, "Decline and Fall of the Roman Empire." 
had put them all to flight, and he had even pursued the party and recovered the Consul's horse, which they were carrying off. In this affair he had dropped his lance, and used only a dabuis or mace studded with nails, and had brought this down on the head of the man he was pursuing and killed him on the spot.

This honest giant was once in love; and his conduct of his affair of the heart, with its unromantic ending, is a good trait of desert manners. There had been an old alliance between Akhmet and Jedáan, and they had taken the oath of brotherhood, which binds the swearers to give mutual aid and protection in time of war; so the Moáli and the Fedáan had for some years fought side by side. But it happened that, in one of Jedáan's numerous quarrels, he was left to fight it out alone, although he had sent word of his difficulty to Akhmet. As soon then as the fighting was over, he dispatched a messenger to ask explanations of his brother, and the answer he received was as follows: "Akhmet refuses to fight for the husband of a woman he loves." This was the first news Jedáan had of his brother's displeasure on account of his marriage with a Moáli girl two years before, and by whom he already had a son. Jedáan's conduct on the occasion was characteristic. "This is too small a matter," he said, "to stand between friends. Take her. She is yours," and he sent the woman to the Moáli Sheykh's tent. She is still 
living, I hear, with the Moáli, and has children by both husbands.

Akhmet Beg got his wish of not dying in a bed only two years ago. He was run through the body in a mêlée with the Shammar, and died without a word. His place is now held by his cousin Mahmoud, who has spent some years at Constantinople, and is supported by the Turkish Government. Mahmoud Beg is, however, unpopular with the tribe, who are said to be only waiting to depose him till Akhmet Beg's son, now fourteen years of age, shall be old enough to take his legitimate position as Sheykh.

With such tales as these our December evenings passed pleasantly cnough; and the original plan of a mere journey down the river to Bagdad expanded into the wider scheme of a systematic progress through the Bedouin tribes. A page from my journal will show how the idea first took a definite shape :

"December 15th.-Wilfrid was talking to-day with Mr. S. about the Ánazch, and their annual migration towards the Nejd; and a discussion arose as to the limit of their wanderings southwards, Mr. S. asserting his belief that these occasionally extended even to Jebel Shammar and the Nejd. No European, however, he admitted, had ever accompanied the Ánazeh on their journeys, and he himself had visited them only in their summer quarters, the upper desert of Syria. It 
would be very interesting to solve this problem; and Wilfrid, without thinking that the answer would be an encouraging one, asked whether it would be possible for a European to tack himself on to the tribe, and so make the journey with them. Mr. S. to his surprise answered that it certainly could be done, and why should not we do it? According to him it would not even be a dangerous experiment; and only tact and patience would be required, in enduring the tedium of Bedouin life during several months, and the courage to be all that time beyond the reach of Christian help. Wilfrid is now full of the idea. For me I an only afraid of being away from England longer than we intended; and we should get no letters all the time. Otherwise the plan seems agreeable enough. The actual travelling would not be tiring, as the Bedouins when on the march go quite slowly; ten or twelve miles a day; and we should have an opportunity of seeing, what has always interested me, the original home of our English horses."

It was settled then that we should start, as soon as preparations could be made for so serious an expedition, and join the Ánazeh wherever they might be. They had already departed from the neighbourhood of Aleppo and were supposed to be somewhere to the south-east, between Palmyra and the Euphrates, and Mr. S., as a first step, sent at once for a certain Scyd Akhmet, the Sheykh of a 
[CH. III.

small tribe living on the borders of the desert, to get more certain information of the strength of the Ánazeh and their proceedings.

The next thing, and this was my especial business, was to have a tent made, for the only tents procurable at Aleppo are the round Turkish ones, which are quite unsuited for an expedition in light marching order, such as we intended to. make. A Turkish tent is a very cumbrous affair, requiring half a dozen people to pitch it and a camel to carry it. It is besides easily blown down and is miserably draughty in cold weather. So. we agreed it would be better to have a tent made on our own plan, a plan which had stood the test of more than one campaign, and always satisfactorily. It is low, but covers for its size a great deal of ground and can in wet or windy weather be made. almost air-tight, while under a hot sun it is transformable into a gigantic umbrella. But I will not: deseribe it further, although, as it was in great measure the work of my own hands, I took some. pride in it when it was finished, with its red lining; bound with white braid. The actual sewing was done by three Jews, who came every day to the Consulate and stitched from dawn till dusk at the rate of half-a-crown each, sitting cross-legged on the floor in an outer room; very honest workers and careful of every shred of stuff given them. As I was standing by them, giving directions one morning and showing them how to turn the edge 
of the outer seams, so as to kecp the roof waterproof, a strange figure suddenly strode into the room with a loud "Walláh," which made the Hebrews start. This was Seyd Akhmet the Sheykh of the Hannády, and, as he was the first Bedouin we saw, I will transcribe my impressions. of him as I wrote them :-

"Seyd Akhmet is a rough-looking ugly man of fifty-five or sixty, without other distinction than what his Bedouin cloak gives him, and his goodnatured countenance, considerably tempered with craft. He is just what they used to call in England, in the days of loncly farm-houses and unfrequented roads, a "sturdy beggar," - a mixture of good humour, effrontery, and servility, neutralising each other perpetually, and preventing you from either wholly respecting or wholly despising him. You are forced to laugh. I confess I am not displeased with his face. I am delighted to find, too, that I can understand his Arabic a little better than that of the scrvants here. This is, I suppose, because he comes originally from Egypt. He pronounces the g's or j's hard. The Bedouins, too, speak more distinctly than the townspeople, who clip their words and leare out their k's, just as Londoners do their h's. Seyd Akhmet's words come rolling out one by one, and we have time to recognize at least some of them.

"He informed us that the Ánazch left the neighbourhood of Aleppo some weeks ago, and are at the 
present moment congregated at the foot of the Bishari hills some twenty miles north-west of Deyr, a village on the Euphrates; but, as he expressed it, they all have their heads now turned towards the south, and may be expected to start in a few days for the Hamád or Great Desert. There they will linger perhaps for another few weeks, and then move altogether southwards. We asked him about Jebel Shammar and the Nejd, but he does not seem to know much about this. His own tribe never moves far away from Aleppo. After telling us all he knew, he began to grow plaintive, asking in a begging voice whether we were going to give him 'nothing to eat' (a Bedouin paraphrase for money). He had been sent for, he said, from a long way off and was hungry. He even performed the little pantomime of pulling an empty purse out of a corner of his shirt sleeve, to show that he was penniless. It must have been put there on purpose. He was very funny with Mrs. S., whom he pretended to be much afraid of, fearing her evil influence with her husband; and creeping up, when she was looking another way, he suddenly tied a knot in her shawl. This, it seems, is a form of appeal among the Bedouins when they would seek protection, and signifies that the supplicator appears as the 'individual' of the person he would propitiate, 'sa chose,' as one would say in French. All this was not very dignified, but there was a good-humoured twinkle 
in the worthy man's eye which half redeemed his action from servility, and he took the matter with the best possible temper when Mrs. S. sent him about his business."

I have given this description as that of the first Bedouin we saw, and, though poor Seyd Akhmet was not a very distinguished specimen of his race, it will give an idea of the common Bedouin way. The Hannády it must be remembered are not a "noble" tribe, being in fact of Egyptian origin, and they have been contaminated by their long connection with the townspeople of Aleppo. No Ánazeh Sheykh would condescend to such manners. But as yet we knew nothing of this.

Thus started, the idea of visiting the Ánazeh rapidly grew into a settled plan, Mr. S. promising to see us, at least some part of the road, on our way. 


\title{
CHAPTER IV.
}

\author{
"En la ciudad de Xeres \\ Se crió un zapatero, \\ Llamado Curro Lopez. \\ De nada tuvo miedo."
}

Andaltsian Ballad.

The Castle of Aleppo-Inscription relating to King David-Legend of St. Zacharias and the Muédin-The prisons of Aleppo-Strange justice-Curro the Kurd-We give half-acrown to a murderer, and offend public feeling.

Alu this while I have said nothing about the town of Aleppo, which was to have been the subject of last chapter, but the fact is both Wilfrid and I are extremely poor sight-seers and care for anything better than looking at mosques and monuments, and it was with difficulty that at the end of a fortnight we summoned up courage to pay a visit to the citadel. It would certainly have been foolish to omit doing so, for the fortress of Aleppo is probably unique in the world as a purely artificial place of strength. It consists of a circular mound half a mile across at top and some three hundred feet high, cased with smooth stone after the fashion of the pyramids. Around it runs a broad ditch, about sixty feet deep and cut in the rock, to which time has given all the appearance of a natural ravine. The summit is crowned with massive 


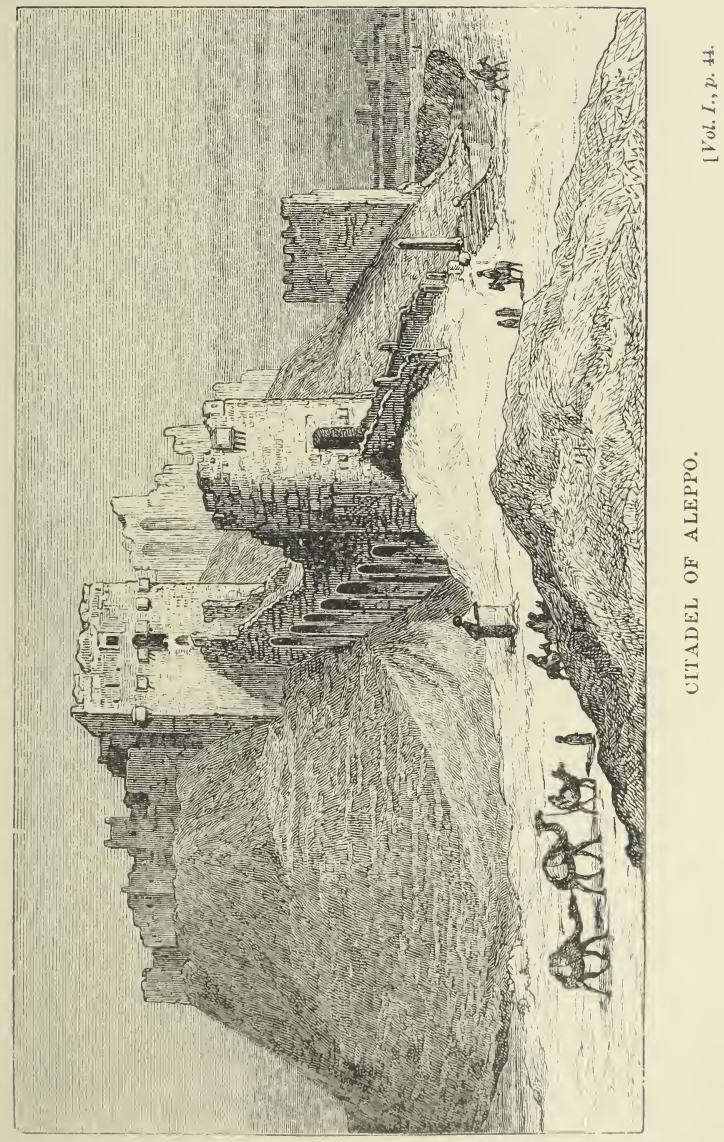




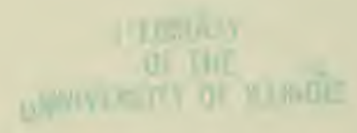


walls of red sandstone, and is reached by an imposing gate and covered way containing a staircase. There is one clear unbroken face of masonry two hundred feet sheer, and an arch spans the moat at little less than that height. Who first made the mound nobody knows, but the existing walls of the fortress were built by Khosroes, king of the Persians, in the sixth century. Saladin took it June 12, 1183, and Malek-ed-Daher, his son, possessed it after his father's death in 1189.* A rampant lion, Khosroes' device, may still be seen on the walls. The whole is much rent and dismantled by the earthquakes, which have visited Aleppo at intervals of about fifty years ever since the time of Justinian. Nothing less could have touched such masonry. It is strange that in these rlays, when everything is known, so grand a monument should have so little notoricty; but Aleppo lies out of the track of the Syrian tourists, and to more serious sight-seers, fresh from Babylon and Nineveh, an antiquity dating from the sixth century seems but a Cockney affair. There was, however, formerly an inscription in Hebrew, pointing to a much older date. It was on a wall, close to the gate of the castle, and was thrown rown and buried by the earthquake of 1822 . It ran as follows:-"Joab son of Zeruiah, in the days of David the king, took this castle from

* See $\Lambda$ bulfeda and Kamel Alterarykh in "Recucil des IIistoriens des Croisades." 
Hadadezer king of Zober, whom he smote in the Valley of Salt." I have this on the authority of the chief Rabbi of Aleppo, who remembers it. It may yet be re-discovered among the rubbish, which chokes up the building, and seems worth recording.

Besides the fortress, there is little of interest in Aleppo, though the town is handsomer than most oriental cities, being built throughout of stone. There is one great square tower, however-the belfry of St. Zacharias-to which a curious story is attached, not yet, as far as I. know, noticed by travellers. It appears that, after Aleppo was captured by Khaled, the general of Omar, the Christian churches were, according to custom, converted into mosques, and a muédin was sent to each tower to give out the daily calls to prayer. But it so happoned that the muédin who first ascended the tower of St. Zacharias fell from the top and was killed. A second met with the same fate, and, when a third was chosen, he, being an old man and frightened at the end of his two predecessors, stopped below in the church to pray instead of going up the stair, and while thus engaged was addressed by an aged man who told him not to fear ; that he, the speaker, was Zacharias, and that he would spare him from the punishment of his sacrilege on one condition. This was that at midnight he should gire an extra call, repeating part of the Greek liturgy. The muédin assented, and the 
Christian call has been repeated ever since, handed down orally from muédin to muédin to the present day, but unknown to the faithful of Aleppo, who hear it but do not distinguish the words. These are "Karchis Allah, Karchis el Káwi, Karchis illési la yemút, erhámna," or in Greek, "Agios "o théos, ágios "o ischyros, ágios "o athánatos, eléison imás." The story may be apocryphal, but the practice is certain, and is the only instance in Islam of a midnight call to prayers. Moreover the words are strange, place and circumstance considered.

"December 29.-We thought we should like to. see the prisons and a certain celebrated robber confined there, of whom we had heard tales which interested us. Accordingly we went to-day to the serai and called on Kiamyl Pasha, the present valy of Aleppo. He received us with the usual Turkish politeness, conversed with us in English and at once granted our request. But first he proposed that I should visit his 'house,' and himself led the way through a couple of rooms where several secretaries sat writing, then along passages, up and down steps, round corners and lastly by a. steep stone staircase into a large square court with a square tank of water in the middle of it. At the door of a handsome room furnished with French tables and chairs we were received by the reigning wife, a young lady apparently about serenteen years. of age and of an agreeable comntenance with almond shaped eyes; she comes of a well known 
family, being the granddaughter of Jessar Pasha. She wore a crimson merino dressing-gown trimmed with narrow black lace; and a piece of gauze passed under her two long plaits of hair and tied in a bow on the top of her head completed the costume. We sat down on chairs and talked, Kiamyl interpreting, for she speaks nothing but Turkish. When coffee was over I thought that the visit might end, but the Pasha would not move until I had eaten some sweets and seen the children. A fat nurse brought in a tray with some bergamot which is better than the name promises, for in taste it resembles clotted cream. The same nurse then fetched the two children, a baby and a boy of three, both dressed in dingy blouses of dark calico, of whom their parents were evidently not a little proud. After sufficiently admiring them I took leave and was reconducted by the Pasha to the reception room, where Wilfrid had been waiting for an hour trying to make the time pass by smoking cigarettes and conversing with Kiamyl's eldest son, a very shy young man who hardly ventured to open his mouth.

"The Pasha then sent an aide-de-camp to show us over the gaol which adjoins the serai or official government house. A prison is not usually a cheerful place, but this was an exception; and if ever it is my fate to be shut up for six months, I trust it may be at Aleppo, rather than at Lewes or Guildford or any other of the well ordered establishments 
of a Christian country. Here the prisoners, apart from the loss of their freedom, have little to complain of. The gaol consists of a great open court, with a row of buildings on two sides of it and a cheerful south-easterly aspect. The walls on the other sides are not so high but that there is a pleasant view of the citadel and part of the town. The cells for common prisoners are on the ground floor, and those into which we looked seemed comfortable enough with carpets and cushions, just like any peasants' rooms in a Syrian village. Three or four men inhabit each; and they enjoy there the full privilege of eating, talking, quarrelling, or sleeping, as it suits them, or of joining in the general society of the prison yard, subject only to the surveillance of a squint-eyed gaoler and the occasional discipline of his stick. An upper storey, with a cheerful balcony, low enough to allow of conversation with those below, is reserved for the more dangerous prisoners, murderers, highwaymen and debtors. Some of these were in chains, but all looked fat and healthy, and, being dressed en bourgeois, were undistinguishable from the most respectable citizens of Aleppo. In fact the prisonyard might, from its appearance, have been taken for a rather animated part of the bazaar, only that there were no shops, and that the honest fellows lounging about were without visible employment or occupation. One of those pointed out to us was a boy of eighteen or nineteen, the son of a former

VOL. I. 
cavass of the English Consulate. He was under condemnation of death, and the history of his trial will serve to illustrate the strange way in which justice is administered in the Ottoman Empire. His father, a very worthy man, was, as I have said, one of the Consular cavasses (armed men who attend on European officials to protect them and add to their dignity). He was a Mussulman, but one day, being jeered at by some ill-conditioned fellows in the bazaar as the servant of an infidel, he had foolishly resented their laughter, maintaining that his service was honourable, and had been hustled by the mob and stabbed to death. The matter was of course taken up warmly at the Consulate, and the murderers were arrested and convicted on the evidence of bystanders. But the execution of the sentence was stayed, on a memorial being presented purporting to have been signed by the principal inhabitants of the quarter where the witnesses lived, and stating that these witnesses were well known as professional givers of false evidence. The men accused were about to be released, but, in deference to a telegram from Constantinople, were detained until a commission should arrive to pronounce upon the case. The commission, under Reshid Effendi, reported the signatures attached to the memorial to have been forged, and ordered a new trial. Now it is necessary in Turkey that, in cases of murder, the nearest relative of the deceased should head the prosecution, and this had 
been done on the occasion of the first trial by Ibrahim, the young man we saw in prison to-day. But, just as proceedings were being opened a second time, another murder, in no way connected with the first, took place in Aleppo. The cavass's son was arrested for this, tried and condemned; and he being, from his present position as a felon, disqualified for prosecuting his father's murderers in the case he was conducting, the trial has fallen to the ground. I think it hardly necessary to make much comment on this, but I will add that Ibrahim's previous character was a good one, and that the evidence on which he was condemned is considered unsatisfactory. I should be very sorry for the young man, if I were not convinced that the matter will be compromised, and that, on his assurance that he will not prosecute his fathcr's murderers, he will himself be released. The story is a curious one, and I should like to recommend it to Lord Salisbury's notice.

We were disappointed of seeing Curro, the picturesque brigand of whom we have heard so much, as he was removed a few days ago to the prison at Jaffa. His history is so like that of his namesake Curro Lopez in Spain, that we might almost suspect him of plagiarism.

He began life as a zaptich (carabinero), succecded to a small property, a vineyard, at Aïntab in this province, and for some years led a quiet uneventful life. Unfortunatcly he had a neighbour, who 
coveted his land and commenced a suit with him for its possession. The neighbour was richer than he and won the case; and Curro, disgusted with law took to the hill ("el jebel," Arabic; "el monte," Spanish). His first exploit was the counterpart of José Maria's. He stopped a captain of infantry on his way to Homs, took from him seven thousand piastres, which happened to be just the price of his vineyard, and sent him to Aleppo with a bill for that sum drawn on the Valy. After this he got together a band of followers. His plan in choosing his men was to run a race with each candidate to the top of a certain hill, and if the man kept near him to enlist him. He was himself an astonishing runner. He generally went on foot, but on festive occasions, such as weddings, feasts of circumcision and the like, he often appeared exceedingly well mounted. He was a little man, but good-looking and excellent company, so he was a favourite everywhere, and might be met at most of the merry-makings in the country. He was polite and brave, but, unlike his Spanish namesake, only shed blood in self defence. This was remarkable in a Kurd, for such he was by birth. He was distrustful of his comrades, sleeping none of them knew where, and joining them every morning at daybreak. His exploits might fill a volume. They were generally of a dramatic kind. He once met a peasant carrying a basket of grapes on his head. "What are you carrying that heavy basket for?" 
he said; "have you no donkey?" "No," said the man, "my donkey died, and I have no money to buy another." "What do donkeys cost in your" village?" he asked. "Five hundred piastres." "Well, here is the money. Get a beast to do your work, or, when I come this road again and find you with your baggage on your head, I will cut it off." Another time he came across a man who had been working in Aleppo for a year, to get money enough to marry a girl he was engaged to, and who was going home to his village with the produce of his year's labour. The man begged Curro to leave him his money, otherwise he said he must go back and begin again. "What," said Curro, "can you be married for six pounds? Nonsense. You can never have dancing at your wedding for that. Here is something to make the sum respectable. I hate a pauper wedding." The man went on his way rejoicing.

A Turkish Effendi travelling from Alcppo to Orfa encamped near the village of Katma. The villagers sent to invite some of his followers to a merrymaking, and the Effendi, unsuspecting, consented. All, or almost all his servants went to the village, the inhabitants of which being Kurds were in league with Curro. In the middle of the night the brigand lifted the flap of the Effendi's tent and requested him to give up his money. This done, Curro looked round and saw several firearms, and among them an English double-barrelled fowling 
[cr. IV.

piece, which he took up and examined. "I must have this," he said. The Effendi in vain besought him not to take away this gun, he should never be able to get another, and being a sportsman should be miserable without it. But Curro laughed, and handling the weapon found it was loaded. "Coward," he said, "and you did not dare to shoot me?"

A Jew of Aleppo, a British subject, was robbed by Curro of some merchandise, and made a claim through the British Consulate of $£ 160$. Curro hearing of this wrote to the Pasha, beginning his letter "My dear friend," and explaining that the total value did not exceed 227 . He enclosed a regular merchant's invoice of the goods, with samples, to show the truth of the statement, and said he felt obliged to do this in the interests of honesty.

Once, meeting a bridal party on the road between two villages, he joined them and introduced himself. They assured him they had no money, being poor people, but he answered that the gold coins on the bride's neck were a legal tender. "What," said the girl, "and you call yourself Curro!" The brigand gave up the coins.

Curro used to go into Aleppo in broad daylight and openly walk about the streets and bazaars, where everybody knew him, yet nobody for a long while betrayed him to the authorities. But fate of course was waiting for him, though he had escaped 
it many times. He was taken at last in a trap laid for him by a miller, a Christian, who was a friend of his, and who used to lodge him at Aleppo. Soldiers were hidden in the mill, and Curro was seized and delivered up to justice. There was no charge of murder made against him, but he has been condemned to fifteen years' imprisonment for robbery. Mérimée would have made a good story out of this.

Before going, we asked to see the prisoner who had bcen longest in gaol. He was called down from the balcony and made to stand in an attitude of attention and display his singularly unattractive features. He had committed a murder eighteen years before, and seemed a brutal ill-conditioned fellow, but we were sorry for his long imprisonment, and Wilfrid gave him a mejidie. (The prisoners have to find themselves in everything but bread and water.) The proceeding, we were sorry to sec, gave offence to the officials present, and we felt rather ashamed at having thus publicly rewarded crime, a feeling which increased when Mr. Nakóus, the Consular dragoman who was with us, took us aside and explained that we had made a mistake. We begged him to assure the Governor of the gaol that our intention was merely a charitable one. "That is very well," said Mr. Nakóus, "and I perfectly understand your feeling; but it should have been a piece of gold, not silver. A crown piece was unworthy of a gentleman of the Bey's dis- 
tinction." After complimenting the Pasha on the excellent state of his prisons, we returned to the Consulate much impressed by all that we had heard and seen. 


\section{CHAPTER V. \\ "Two pairs of boots, lined with fur, were also taken." \\ Cockle's Advertisement.}

We buy horses, being resolved to join the Ánazeh-Hagar-News from the Desert-Wars and rumours of wars-Jedáan at bay -The world is much " mixed up"-A chapter on politics.

IT was now definitely settled that we were to join the Ánazeh, and throw in our fortunes with them for the winter, and that we were to start as soon as our arrangements should be completed, and a break should occur in the weather. But a journey of such uncertain duration could not be undertaken lightly, and there was much to prepare and much to be thought of before leaving Aleppo.

Besides the tent, which was now finished, we had horses to buy and mules to engage. Seyd Akhmet was of use to us in procuring the first; and, as it happened, the moment was a very favourable one for purchasers. There had been fighting in the desert, and nearly every day a mare would be brought in, often with spear-wound still gaping in evidence of her being prize of war. These mares were easily distinguishable from the beasts possessed by the townspeople, by their ragged unkempt appearance and their emaciated state, for 
many of them had been ridden day and night from great distances to be brought to market. I cannot say that in general they were good looking, but, here and there, there was an animal of fine shape and evident breeding, though woefully disfigured, may be, with broken knees or marks of firing.

After much picking and choosing, however, Wilfrid was fortunate enough to secure, for a very moderate sum, one of those mares, rare enough, as we found out afterwards, even among the Ánazeh, which make one understand the relationship existing between our English thoroughbred and the Arabian horse. She was not remarkably handsome, being ewe-necked, and having a strange, wild head; but her depth of girth and her long muscular hindquarters gave promise of what she really possessed in a wonderful degree, speed and staying power. These we might find very necessary in our adventures. Endurance of fatigue on the road and hardiness under want of food are qualities that may always be reckoned on in buying an Arab horse, no matter what his looks or what his pedigree; but speed is exceptional, and confined to the best strains of blood. Hagar, as we called her, was of the Kehîlan-Ajúz breed, the fastest, the stoutest, and the most English-looking of them all. When purchased, she was in very poor condition, having just gone through the severe training of a campaign. She was bred by the Gomússa, the most notable of the horse-breeding 
tribes, had passed from them to the Roála, and had now been captured and ridden some two hundred miles in hot haste for sale to Aleppo. She was a five-year-old mare, a bay with black points. We never met anything in our travels which could compete with her over a distance, and she has often run down foxes and even hares, without assistance, carrying thirteen stone on her back. She was of a mild, gentle temper, and always went smoothly on, without fret or hurry, and with the long low stride of an English racehorse. She never galloped better than when she seemed worn out with work. She had the advantage, too, for Wilfrid, of being tall, fifteen hands, an unusual height among Arabians.

My own mare was to have been a Maneghíeh, also a powerful mare; but, as it turned out, I never rode her, for she got an accidental sore back before we started, and it ended in my starting on a horse lent me for the occasion, which I changed later for something better at Deyr.

The Consul, who was to accompany us for a part of our journey, had provided himself with a sorry-looking, cream-coloured pony, of no pretensions to breed or good looks, but which he knew. It had formerly belonged to the courier who rides with the post from Aleppo to Alexandietta, and was bred at Beylan. It was the type of the lowbred country horse of Syria, resembling very closely the Assyrian war horses on the bas reliefs at 
Nineveh. The likeness is striking, and the form of both animals contrasts curiously with that of the Arabian horse, not known at that time, perhaps, in Assyria.

Then we had a cook to engage, and lit upon a real treasure in the person of Hánna, a Christian of Aleppo, who had never indeed been out of his native town, and who spoke the most mincing of town Arabic, but who proved a faithful and courageous servant in all our subsequent adventures,-this for only two hundred piastres (forty francs) a month.

As for baggage animals, the first part of our journey would be along the Euphrates valley, where the ground in wet weather would not be favourable for camels; and it was agreed that we should engage our old friend Hadji Mahmoud and his mules again, and trust to purchasing camels later, when we should have joined the tribes. In this we broke through our usual practice, which is, to buy everything and hire nothing on a journey; but beasts of burden seemed far from plentiful at Aleppo, and we were assured that we should find a better market for them at Deyr, which was but two hundred miles off, and where we should know exactly what our further proceedings were to be. This, as it turned out, and as we ought to have foreseen, hampered our movements considerably, and obliged us to go, not where we would, but where we could get our muleteers to go. 
Besides these things, we had cloaks, boots, tobacco, and sugar to buy, as presents for the Sheykhs whose hospitality we were about to claim. These gifts are entirely conventional, and do not in any way represent payment for services rendered. The offering of a cloak is a complimentary usage, and its value must be nicely graduated according to the rank of the giver and that of the receiver. As we afterwards found, it requires some tact to know exactly whom to honour and whom not to honour with these presents of ceremony; and an inch or two of embroidery more or less may make the whole difference in your position with a Sheykh you are anxious to oblige, or with his neighbours whom you cannot afford to offend. The boots are less necessary; but they also are usually given to be passed on to servants; while the tobacco and the sugar are offerings which more nearly touch the heart, and are added as something more than a symbol of gooswill. With them the inner tent is propitiated; the screened-off dwelling where the women cook and chatter.

A few more pages from my journal will explain the excitement in which the last few days of our stay at Aleppo were spent:

December 30.-This morning a wild-looking little Arab, in a very tattered cloak, and mounted on a rat of a mare, rode into the garden with Seyd Akhmet and his nephew, Jemáa. He was an Ánazeh, of the Gomússa tribe, who had been sent by Ibn 
Mershid, their Sheykh, with his compliments and a message that, hearing of our intended visit to the Ánazeh, he hoped to have the honour of receiving us. The man had come in from Bíshari, a ten days' ride; and the fact shows that the Bedouins have a well organised system of obtaining news, as it is not three weeks since our journey was first talked of among ourselves, or a fortnight since Seyd Akhmet heard of it. Besides his message, he had a serious piece of news to give. It appears that the Roála are at open war with the rest of the Ánazeh. According to his account, it was begun by their stealing some camels belonging to the Sebáa, a rich but unwarlike tribe, who, in the fighting which accompanied the raid, lost five of their men prisoners to the Roála. These, contrary to all law and custom, and for some unexplained reason, had their throats cut by the victorious tribe; a thing the like of which has not happened for generations, if ever; whereupon, fearing the vengeance which would certainly follow on their crime, the Roála fled to Homs, and put themselves under the protection of Yusef Pasha, the Turkish governor. He, pleased enough to interfere, invested Ibn Shaalán, their Sheykh, with a robe of honour and the title of Sheykh of the desert, and sent a body of troops to help them. In this evil company they advanced against the Sebáa, who retired before them, sending to Jedáan for assistance, which was at once given. The Fedáan 
and Sebáa together now turned upon the Roála, put the soldiers to flight, and captured twenty of their enemies, whom Jedáan at once treated as they had treated the five Sebáa. He then returned to the neighbourhood of Deyr, where he still is, while the Roála have fled south into the Hamád. This is an ugly story in every way, but it need not have any effect upon our own proceedings. The Roála will naturally keep clear of their offended kinsmen, and will not go with them to Jebel Shammar this year; and it may even be fortunate, as their being all in trouble may make Jedáan still more anxious to do a service to so powerful a friend as Mr. S. The Ánazeh, however, are likely to hasten their journey southwards, and we must start immediately if we wish to find them still within reach. Wilfrid sent at once for Hadji Mahmoud, and agreed that he should take us, with five baggage mules, to Deyr, and that we should start on Wednesday . . .

January 3, 1878.-Great news has come from Deyr. The Roála, it appears, upon their defeat by the Sebáa, sent to Ibn Sfúk, the Shammar chief, for help, and he despatched at once his nephew, or cousin, Smeyr, to the Hamád. This Smeyr, after seeing the Roála, went on to Jebel Shammar, to claim the assistance of Mohammed Ibn Rashid,* which in turn was granted; and now the southern Shammar, with Ibn Rashid at their head, are marching with the Roála to attack Jedáan and the * Brother of Telál Ibn Rashid, Mr. Palgrave’s friend. 
rest of the Ánazeh in the north. Jedáan has left Bíshari and has taken a more defensible position at Esseríeh, where the Weldi, a tributary and friendly tribe, are encamped, and where there is a line of hills about half way between Palmyra and Deyr. The latter town is frightened at these preparations for war, and troops are being sent there from Aleppo. On the whole, a pretty kettle of fish; and our prospects of getting to Jebel Shammar this year are growing doubtful. Wilfrid says our best chance is to join Jedáan at once, help him in his fight with Ibn Rashid, and then, if victorious, go down with him south as he pursues the Shammar. But this will depend on the chances of war; and Mohammed has guns, while the Ánazeh have none. Another plan he thinks would be, to join the Roála, by which means we might easily make friends with Ibn Rashid, and go back with him; but our sympathies are more or less pledged to the Sebáa now, and we could not side against them in a crisis like this. Mr. S. is on friendly terms with both; but his principal ally is Jedáan: so to Jedáan we must stick. Besides it is a far cry to Jebel Shammar; and Mohammed can hardly take the field in any great force. The Roála muster perhaps twenty thousand lances; but the Sebáa can bring twice as many into the field; and Ibn Rashid's matchlocks will hardly make matters equal between them. Jedáan, too, has the reputation of being a great warrior and a prudent general, and has 
chosen his ground. Let us hope for the best. If fighting takes place during our stay with the Ánazeh, Wilfrid will be expected to take his share of it. He would not wish to use firearms, unless firearms were used against him; but it is as well to be ready, so we have spent the morning casting revolver bullets and making cartridges. To quote Canon Tristram: "As we dropped our bullets into our fowling pieces, I breathed a fervent prayer that no blood might be shed."

January 4.- Seyd Akhmet came again with confirmation of the war news from Deyr. Everybody is of opinion that Jedáan will be beaten, and perhaps even forced to surrender, at Bíshari; for it is by no means certain that he will be able to make good his retreat on Esseríeh. Ibn Sfúk and the Shammar from Mesopotamia have probably already crossed the Euphrates to cut him off, and, if they succeed in this, he will be isolated, as the Moáli and the rest of his allies are still far to the north. Wilfrid fancies they make too much account of Ibn Rashid's guns, which are no doubt wretched pieces of ordnance, and it appears there are only two of them; but everybody here thinks Jedáan lost. This is likely to be the greatest war ever known in the desert since the Ánazeh drove out the Shammar two hundred years ago. If Jedían has to surrender, the Sebáa, who are the richest and most civilised of all the tribes, will be reduced to poverty and, with them, the Fedáan, 
who have the name of being the greatest warriors. The laws of war will give everything they possess, mares, camels, sheep, tents-down to the pots and pans-to the conquerors; and these great tribes will have to depend on the charity of the Moáli and the Beni Sakkhr, or even their old tributaries, the Weldi, Aghedáat and others.

We had a council of war in consequence of this news,-CSeyd Akhmet, who has agreed to go with us, giving us a lively picture of the state of things in the desert. "The world," he said, "is much mixed up at present" (maliloot, mesclada, mêlé), and it may be better to wait events; "but the Beg, whose servant I am, must decide. When he says the word 'mount,' I am ready." Wilfrid is all for going on at once to Deyr, where we shall be nearer to what happens, and where at least we shall see something new, and be on the spot to act as circumstances may suggest. It may be an excellent opportunity, too, he thinks, for buying horses ; as, after the battle, property will change hands, and is very likely to be sent to the hammer. I hope Jedáan may prove a match for his enemies; but I don't quite like throwing in our lot with him just now.

January 5.- There is a new account to-day of the origin of the war in the desert, which just now interests us a thousand times more than all that is happening in Bulgaria and Armenia. It appears that Meshúr, the young sheykh of the Gomússa, a Sebáa tribe, the very one who sent us the polite invi- 
tation a few days ago, has been the principal cause of it all. There was some dispute about camels between the Sebáa and the Roála, both Ánazeh tribes, but old rivals; and the Turkish government, being on bad terms with the former, supported the latter in its pretensions. Sotámm Ibn Shaalán, the Roála chief, thinking to settle matters, called upon Meshúr, and, contrary to all etiquette, did so in company with some Turkish officers who were staying with him. This Meshúr resented, and, in the dispute which followed, Ibn Shaalán was run through the body by the young man with his sword. Mehemet Ali, a former cavass of the Consulate, and a man who knows the desert well, brought us this news; but he only half believes it, and does not believe at all the story of prisoners' throats having been cut on either side, as it is a practice quite anknown among the respectable Bedouin tribes.

Hadji Mahmoud has backed out of going with us, and insists upon double the usual price for the hire of his animals, on account of "war risks," there being some possibility of our meeting a Shammar expedition on its way to help the Roála. Mr. S. would be no protection to us against these, as he has always been on bad terms with the Shammar, and is known as a friend of Jedáan. We shall probably have to take an escort, after all, from the Pasha, who is sending troops for the protection of Deyr, which place seems to be in danger of pillage by one party or the other. It is tiresome, as we shall lose our 
independence; but we know so little of the country as yet that it is best to be on the safe side."

Thus filled with doubts and fears, and reports of war, and anticipations of adventure, the last days of our stay at Aleppo passed. How little the sequel justified our apprehensions will presently appear. In the meantime, before finishing the chapter, I will explain what proved to be the real nature of this desert quarrel of which we heard so much. We did not learn it with any certainty till long afterwards.

The real history then is as follows:-The Turks have at all times held it as a maxim, in their government of Syria, to keep the Bedouin tribes wholesomely engaged in internecine war; securing, by this means, for the country districts adjoining the desert, immunity from molestation by their unquiet neighbours. It is also a time-honoured practice with the Pashas to remove quietly such of their political opponents as they conveniently can, by any of the old-fashioned methods now disused in Europe; and the result, I am bound to say, generally justifies the means, morality apart. It was thus that, two years ago, finding Súliman Ibn Mershid, the Gomússa sheykh, assuming too powerful a position with the Sebáa tribes, the then gorernor of Deyr, in the interest of the public safety, invited him to dinner, and, having entertained him honourably, sent him back, with presents in his hand, to die of an unexpected and hardly natural death in the 
desert. Súliman's people, who adored their chief, were displeased at so sudden a result of the Pasha's hospitality, attributing the Sheykh's discase to a certain cup of coffee he had imprudently partaken of alone; and a coolness ensued between them and the Turkish authorities in consequence. This was adroitly used to produce further complications detrimental to the Bedouins. The Sebra have, from time immemorial, enjoyed the right conceded to them by desert custom of the pasturage opposite Hóms and Háma; while the Roála, their rivals, have occupied the neighbouring district of Damascus. This year, it happened that the latter, grown rich in camels through a succession of favourable breeding seasons, were looking round them for additional pasturage, when they bethought them of the differences existing between the representatives of Súliman Ibn Mershid and the Turks.

It is the weakness of the Bedouin position, in regard of the Government, that, though quite independent of their control during great part of the year, they are obliged, in spring, to seek a market for their young camels, horses and wool, in the neighbourhood of some one or other of the towns. They also have their year's supply of corm to purchase, dates, coffee, tobacco, and even clothes. For this they depend on the goodwill of the Pasha in power, who always makes them pay a round sum for the privilege of trading; and their necessity gives him the opportunity for any 
intrigues which he may be planning among them. A fixed price was paid yearly by the Sebáa for their privilege, and the use of the pasturage of Háma and Hóms. But Sotámm, the Roála sheykh, came forward, this year, with an offer of nearly twice that sum and, by a private gift of mares to the governor of Háma, secured his support in occupying the pasturage in their stead. The Sebáa, coming up from the south, found the Roála already in possession; and, refusing to retire, were presently attacked by them, and by a body of Turkish infantry, Sotámm's allies. The camps of the Moáyaja and Gomussa, two of their tribes, were sacked, teuts, nousehold furniture, camels and mares taken; and the Sebáa were driven back to the southern desert. These now called upon Jedáan, their new alid or military chicf, to help them with his own tribe; and, thus reinforced, they turned the tables on the Roála, who, deserted by the Turkish Government, which had got all it wanted, were left to fight it out alone. Jedáan defeated them in a pitched battle near Jabúl, taking many mares and killing some fifty of their men (a large number for a Bedouin battle); and they wero forced back in confusion to their old quarters near Damascus. It was then that they sent to Ferhán, the sheykh of the Shammar, and to Ibn Rashid, for help; and that Smeyr, Ferhán's cousin, was dispatched on a diplomatic mission to Hîyel to negotiate matters for them with his kinsmen of 
Jebel Shammar. There seems, at one time, to have been an expectation of the latter's really helping them; but Ibn Rashid never could have seriously thought of dragging his pieces of ordnance five hundred miles across the desert on such an expedition. Smeyr's mission failed ; and the Roála, being still pressed by their enemy, retreated to their winter quarters in the Wady Sirhán, leaving Jedáan with the Sebáa to enjoy their triumph at Bishari till, at the usual time, they followed them in their migration into the Hamád. At the time we left Aleppo Jedáan was still at Bíshari.

This rather long and, I fear, dull account is necessary for the right understanding of the Bedouin politics which so much interested us all through the winter. Later on, and when the chief actors of the drama come upon my stage, I hope to make these matters more generally entertaining. 


\title{
CHAPTER VI.
}

\author{
" Shall packhorses, \\ And hollow pampered jades of Asia, \\ Which cannot go but thirty mile a day, \\ Compare with Cæsars and with cannibals, \\ And Trojan Greeks." \\ SHAKESPEARE.
}

We leave Aleppo--Wandering in the dark-An Arab village-The Desert-First view of the Euphrates-A Weldi camp-Zaptiehs -A melancholy exile and a dish of francolins-Bivouacking by the river.

January 9, 1878. For a party of old travellers, such as we are, our start this morning certainly was disgraceful. Upon a journey, it is prudent to make the first day's march an easy one ; and, for this reason, we had chosen Jabúl as our stage, only fifteen miles from Aleppo, hoping to be in early enough in the afternoon to get our things about us before it should be night. It had been arranged with Seyd Akhmet that he should take us to the house of one of his people there; and we thought that the arrangement would save us trouble, and that we should find food and shelter ready for us on this, the first night of our journey. But all has gone wrong.

Wilfrid of course was up at cockcrow, and had the baggage out in the yard, almost before the sun 
was up; but the rest of the preparations were not so forward, and it was half past nine before the baggage animals could be dispatched. So far, however, so good; but with ourselves it was a different matter. First, a message arrived from the Serai to enquire whether we really intended to start this morning; for, in the East, it is not usual to start on the day fixed, and the escort we had agreed to take was but half ready; then Mr. S. discovered that he had certain matters of business to transact, before leaving the Consulate, and despatches to write; a mare too, which had been purchased to share Creamy's duties, was found, unaccountably, to have a sore back; and Seyd Akhmet had not appeared. Lastly, it was agreed that, so much time having been lost, it would be imprudent not to wait a little longer, and have breakfast first.

In the course of the morning, the zaptiehs, $\mathrm{Or}^{\circ}$ mounted police, four men and a sergeant, arrived, representing, they informed us, the body of fifty regulars promised by the Pasha. The fewer the merrier, we thought; for, in truth, they are not very attractive companions, if looks be any index to character. The sergeant, Súliman Aga, is a broadshouldered, powerful Turk, with a heavy dark countenance made darker by a black head-dress. He wears a sort of military cloak, but is not otherwise in uniform; and his men are undistinguishable from the country people, at least to mupractised 
eyes, except by the colour of their liefinges (handkerchiefs for the head). They seem goodhumoured though, and perhaps will improve on acquaintance. At half past one the horses were saddled; and, a little after, the last adieux made. Then we all mounted; and, accompanied by a crowd of retainers from the Consulate, crying, as the custom is, and kissing the consular stirrups, we rode away, with only four hours of daylight before us, and no chance of getting in before dark. Seyd Akhmet, moreover, had neither come nor sent; and it was doubtful where we should find our baggage, as the house of rendezvous was not exactly in the village of Jabúl.

However, we were too pleased to be off to think much of possible mischances. It was colder than ever; and, as we took our way across the desolate hills towards the south east, the wind was just in our faces. The sky was like lead, and seemed to threaten snow. The track we were following was very like that by which we arrived from Alexandretta, stony and muddy; but I should have proposed a canter, as soon as we were outside the town, to warm ourselves, and make up for the lost hours of the morning, if it had not been that Creamy was hardly equal to it, and could not be left behind.

This, however, is to be our last day in cultivated ground, and we must have patience. To-morrow we shall be in the desert. Every here and there, we passed the sites of old villages, or perhaps towns ; 
but their names are forgotten. Just at sunset, we caught sight of the salt lake on which Jabúl stands, and presently we descended from the upper country into a plain, just now turned into a swamp by the heary rains we have been having. Through this we floundered for an hour or two, Creamy coming even once or twice to his linees, a not very pleasant accident for his rider, as the water was almost freezing; and at one moment there seemed a prospect of our having to spend the night out of doors. At last, however, we heard dogs barking, and then saw a light, which we knew must be a village, though it was not Jabúl; and to this we rode through water up to our horses' knees. It is rather a disagreeable thing to have to ride into an Arab village in the dark, as it is sure to be surrounded by a honeycomb of wells, and holes for storing corn; and, more than once, I found myself on the brink of one of these; but horses seem to see in the dark; and there is an Arabic proverb to this effect; so I let my beast grope its own way with a loose rein. The village was not Jabúl; but its inhabitants directed us on our way, and, half an hour later, we were much relieved at hearing a horse gallopping towards us. It was a scout sent out by our anxious host to show us the way to his house. A wretched place it is, as all the fixed habitations of Arabs are, comfortless as a tent, without doors, or windows, or floor and, being immovable, inconceivably dirty. No wonder the Bedouins refuse to change wandering 
homes for such as these. We were shown into a little room about eight feet square, with a bit of dirty sacking hung up before the door, to keep out the wind, and a bit of dirty carpet laid down on the dirtier floor, and a couple of dirty cushions in a corner. In this our baggage was piled, all muddy and squalid and comfortless. A wretched night, but we have agreed it shall be our last under a roof, be the cold what it may.

After all, Eyssa, our host, received no notice of our arrival till the baggage came; so he has not had time to make us a feast. We have devoured our dinner almost in darkness, the cold legs of a turkey provided, fortunately, by Mrs. S., and are looking forward, with no pleasant prospects, to our night's rest. A girl of fifteen, Eyssa's sister-inlaw, was sent to milk some ewes just now, which are folded in a yard about a hundred yards off from the house; but she did it in fear and trembling, on account of wolves, she said, which the cold weather has driven down to the villages. One came into the yard this very afternoon.

Eyssa's father, Batrán, was sheykh of the Hannády, when they were sent from Egypt by Mehemet Ali; a brave man, but ill-famed for his cruelty. On one occasion, having taken prisoners thirty of the Shammar, he cut their throats and threw them into a cave near here. At his father's death Eyssa was too young to succeed as sheykh, and his uncle, Seyd Akhmet, took his place. We 
asked Eyssa how he could be content with the life of a fellál (or cultivator of the soil) when his father had been a Bedouin. He said it paid better. He was growing rich. The fact is, these Hannády are Egyptians, hardly true Bedouins. No Ánazeh, I suppose, would consent to such a transaction. $\mathrm{Mr}$. S. asked him too what had become of Seyd Akhmet. "What!" he answered, "you have known Seyd Akhmet these twenty years, and you have ever known him to keep his word!"

January 10.-Jabúl by daylight is not more attractive than Jabúl in the dark. Like all the villages bordering on the descrt, it is the type of wretchedness and squalor, and life in such places would seem to have no redeeming feature to make it tolcrable. Pastoral life, to be attractive, needs to be nomadic, and the Arabs, eren after they settle and become ploughmen, insist on kecping sheep. The consequence is, the ground, for some miles round their villages, is poisoned and trodden down by their flocks, and is a barer wilderness than any part of the desert. A fixed sheepfold, especially in rainy weather, is as disgusting as a pigstye. As we looked out in the grey morning and took note of all this, it was not hard to understand the contempt a Bedouin feels for his fellows who have become "felláhin."

Warned by the discomforts of our arrival yesterday, we made an earlier start; and a very fer miles brought us fairly into the desert. The sun came out, 
and there seemed a chance of more genial weather ; and with it our spirits rose. There was at first a kind of road or track leading across a perfectly level plain towards a conical hill between us and the sun; but this gradually disappeared, or we left it, and, as we got beyond the poverty-stricken radius of the village, the ground assumed a more cheerful aspect. The loose stones had disappeared, and our path was over a light crisp soil thinly covered with grass; nothing to break its uniformity but occasional lines of mole-hills straight and regular as if drawn mechanically, and sometimes a couple of hundred yards long, and here and there clusters of jerboa holes, except for these, the most beautiful galloping ground conceivable. At the foot of the tell, or mound, when we arrived there, we found the first tents. Shabby as they were, they had a look of neatness after the houses we had left. They belonged to the Hannady, Seyd Akhmet's people; and in the neghbourhood were flocks of sheep, each with its shepherd. It was an agreeable scene, and made us regret that we had not made a better day's march yesterday and pitched our own tents alongside of these. Wilfrid and I rode up to the top of the tell, from which there is a really fine view of level plain stretching green on crery side. It is interesting too as being the scene of Jedáan's late battle with the Roála; and Wilfrid's mare, Hagar, who probably took part in the fight, grew very fidgety as we got near the place. This may perhaps have 
been an accident, but it helped us to realise the scene of battle. The name of the tumulus is Khsáf.

Some ten miles to the south-east appeared another hill, which was pointed out to us as the next landmark for which we had to steer. We left $\mathrm{Mr}$. S. and the zaptiehs to escort the baggage, and pushed on. Everything was new and delightful to us; and there was a lightness in the desert air which made us long for an adventure, if adventures had been possible in such a place and in such company as the tiresome Turkish police. We rode up to one or two of the shepherds and asked them a few questions, which they answered amiably enough. They were very busy separating the new-born lambs from their mothers; for weaning begins here almost from the day of birth. Then we saw a flock of something we took for gazelles or bustards, but which turned out to be cranes from the lake. There were, besides, rooks, grey crows, kites, and several small hawks. Presently we came to a little stream with a border of greener grass on either side, where there were more shepherds. We let our horses drink, as they had had no water since yesterday. This bit of desert is more attractive than any we have seen in Algeria or Egypt. Any part of it would make a race course.

From the second hill we were to see a guardhouse; but of this there was no sign, so we waited till the caravan came up. It consists of seren baggage beasts (six horses and a mule) driven by 
two kátterjis (muleteers), Hadji Mahmoud's brother and another. Our cook, Hánna, (a Syrian Christian, and not a woman, as his name would seem to imply, for Hanna is Arabic for John,) is mounted on the very pony Wilfrid rode from Alexandretta. He has got himself up in a Bedouin disguise, of which he is as proud as Punch; and Mr. S.'s servant, Júrgy, (George), in similar attire, rides a colt of his master's, and leads the mare with the sore back. Súliman, the sergeant, has a cross-bred Arab which is a good walker, and seems up to his rather heavy weight; and the other zaptiehs have rough-looking beasts, one of them only a two-year-old. Mr. S., in a long black cloak and with a yellow handkerchief bound round his hat, gives dignity to the procession. We have come too far to the right, it appears, and now strike a line due east and follow this all day, till at about three o'clock we come to broken ground, announcing the neighbourhood of the great valley of the Euphrates which we are in search of. Mr. S. enlivens the road with tales of Bedouin life and manners, and relates the story of his rescue by Akhmet Beg (mentioned before), on the spot where the adventure happened. Suddenly we come to the edge of the plain, and the valley is before us. Much as I have expected of this, and often as I have tried to imagine the scene since we first decided on our journey, the reality surpasses all.

The valley of the Euphrates is a deep, broad cutting in the desert, with chalky cliffs bounding 
it abruptly on either side. At the point where we came upon it, it is about five miles wide, and perhaps a hundred and fifty feet below the level of the upper plain. The valley is a long, level meadow, green as emerald, and covered with flocks of sheep. We counted twenty of these, with perhaps a thousand shecp in each. Above, wore the tents of the Wéldi, an honest and thriving tribe of Arabs, who often take charge of sheep for the Ánazeh, when they go south, or for the townspeople of Aleppo, with whom they share the produce. A sheep here may be worth five or six shillings. This part of the valley is called the plain of Mélakh; and it was here that Jedáan had the skirmish with Ásmeh Pasha. We could see the river winding to and fro in this great meadow far away, fringed with a deep, brown belt of tamarisks, in great curves and reaches. It seems as big as the Danube at Belgrade. On our way down the cliff, which was by a side ravine, we passed the grave of Abd ul Áziz, one of the Shammar chiefs, who was killed in battle here by the Ánazeh, ten years ago. It is only a cairn of stones.

After this, we turned to the right and went on close under the line of cliffs, for an hour, to a place where the river, having crossed the valley, sweeps round in a fine bend. Here it has been proposed to make the station for steamers, so soon as they shall run. Indeed, the steamer, which has been occasionally sent up for Government purposes from 
Bagdad, already makes this its extreme point up the river; and a little fort and some buildings have been erected for the protection of the place. It is called Mésquineh, and is not marked on the maps. We found all deserted on account of the war. We have looked inside the huts, and have decided that we will sleep out of doors.

January 11.-Mr. S., who has not been on horseback for several years, was so much fatigued last night that we were really alarmed about him. As soon as we arrived at Mésquineh, he got off his horse, lay down on the grass, and went sound asleep; nor could we wake him even for dinner. $\mathrm{He}$ is well again to-day. I suppose our day's journey yesterday must have been close on forty miles. It was fortunately a warmer night than most of those we have been having lately; for the katterjis arrived so late that we had not time to think of pitching a tent. We only got out our carpets and blankets, and slept as we were-on rather short commons too, for no arrangements have been made for our commissariat; and the remains of the turkey and bread was about all we had. Poor, however, as our night's lodging was, we all agreed that it was far better than another such experience as that of Jabuil.

One advantage of sleeping out of doors is, that everybody is ready to get up in the morning. It was so cold that, long before dawn, the servants were astir, making a fire and boiling water for 
the coffec. There is plenty of good firewood from the tarfa, or tamarisk jungle, which fringes the river; and, as soon as it was light, we had breakfast, packed up, and were off. Our coursc lay along the right bank of the river, which here has a general direction of nearly due east. We passed close to the ruins half way up the cliff of Bállis, or Bállesis, principally remarkable for a very tall octagonal tower of Saracenic architecture; an imposing structure, and giving a notion of the importance of this region in former times.

A little further on, we passed another ruined castle, Dipsi, standing on the extreme edge of a jutting piece of cliff, and secured, formerly, from assault by a decp cleft, cut across the tongue of rock connecting it with the upper descrt. In all probability there was once a drawbridge across this. The river just below gives a sweep right under the cliff, so that there is no means of passing below, and one is obliged to climb to the upper plain again. The cliff here is composed of a substratum of chalk, with a conglomerate crust above. The chalk, being the softer of the two, is in many places hollowed out into caves and recesses, which the conglomerate overhangs. These are much used by birds and beasts. Jackals and foxes occupy the more accessible caves, and hawks, jackdaws, and rock pigeons, the higher ones. I think I noticed a Bonelli's eagle roosting in one last night, but I cannot be quite sure. 
The road now cuts off a bend of the river, crossing a bit of very stony desert, and then goes down again into the valley. From the high ground there was a fine view over miles of tamarisk jungle, in which the river is lost; and on the plain below were a number of mud-huts in ruins, called ÁbuGhréra. This is one of a series of villages made by order of Áslan, an enterprising Pasha, about four years ago, for the Ánazeh, whom he thought he had persuaded or bullied into abandoning their nomadic life and becoming felláhin. This, of course, they never had the remotest intention of doing, and the huts were never inhabited.

As we skirted the river, we came upon numerous flocks of ducks, geese, plovers, and, in a small lagoon caused by a late flood, some hundreds of coots. The sergeant, Súliman, could not resist this sight, and unswaddling his gun (for he had it well wrapped up in a red leather case, besides other coverings), went off to stalk his game. But the coots would not sit still for him to take aim, and fluttered away; so he prudently reserved his fire. Wilfrid had left his gun with Hánna, which was vexatious, as we were grievously in want of provisions. A little before sunset, we came upon a Wéldi camp, set at the edge of a tamarisk jungle. Some five-and-twenty soldiers were already quartered on the Arabs; and our escort were, of course, delighted at the prospect of talking, which is one of the dearest pleasures in the East. So we were 
made to dismount and accept the officer's hospitality (the Wéldi sheykh being thrust unceremoniously into the background), and sit on his carpets and drink his coffee, while he entertained us with stories of wild beasts, which, he informs us, infest the neighbourhood. Like all Turks in this country, he is very sorry for himself, bewailing his dreary exile from Stamboul, complaining of the Arabs and the place where he is quartered (it seems to us a garden of Eden), and of the boils with which his hands are covered. He is indeed a piteous sight. He was left at this camp when the rest of the troops were withdrawn for the war, and has been here nearly six months, having no occupations, amusements, or what are called "resources within himself." He urged us to spend the night in his tent, instead of sleeping out of doors, as we should certainly be carried off by lions in the night. Only a fortnight before, some mules had been seized and devoured in broad daylight; and a child had been taken out of a tent somewhere close by. He was delighted to see travellers; and condoled with me very earnestly on the hardships of the road, hinting that he was accustomed to quite a different kind of life, comforts and luxuries "such as these poor Arabs," waving his hand, "had never dreamt of." He asked about the war, or rather, about the prospect of peace, and when we told him that this was likely, went on repeating in a plaintive voice "Inshalláh, in- 
shalláh" (please God, please God) for nearly a quarter of an hour.

Hánna had by this time come up; and Wilfrid, taking his gun, went down into the jungle to see if he could get us something for dinner; for he had heard birds calling in the wood, which he thought must be some kind of partridge. He was away till quite dusk ; and we heard him fire several times. I confess that until he returned the lion stories haunted me, and I had not a quiet moment. He came back, however, and told us that he had followed the birds he had heard a considerable way, and had found that they were calling, as pheasants do when they fly up to roost; but he had not succeeded in getting a shot at one. The wood was full of magpies, and it was difficult to distinguish in the thickets what birds the others were. He had killed a magpie in mistake for one, and then, coming to an open space, had sat down. Presently woodcocks began flying over his head, and he had got three. The jungle abounds with jackals, which we heard all the evening whining close to the camp; but Wilfrid neither saw nor heard any other wild beast. We made our bivouac under a bush just outside the camp, where the soldiers talked and sang half the night. This, with the barking of dogs and the fidgeting of the soldiers' horses, made the evening not one of undisturbed repose; but we were tired and slept well. 
Although the nights are cold, we do not suffer, as we have plenty of things-first an oilskin cloth on the ground, then a turkey carpet, then each a cotton quilt folded double, to serve as bed. Over us we spread our eiderdowns ; and, over these again, a Turcoman carpet, and another oil-skin over all. In this way we do not feel even the heavy dews which fall at night.

January 12.- It was a bright morning; and across the river there was a beautiful view of Jaber, an ancient castle, and once a place of importance.* We had no sooner left the camp than we saw a pair of francolins enjoying the sunshine, just outside the jungle; and Wilfrid was fortunate enough to get them both. The cock francolin is certainly one of the most beautiful birds in the world; and seems to stand about half way between the partridge and the pheasant. He has a magnificent plumage, black, spotted with white; his back and wings russet, and his legs red. The hen is plainer, and might be taken for a hen pheasant that had lost her tail. Like pheasants, they seem to roost in trees, and they were, no doubt, the birds that Wilfrid heard calling last night. Hánna was in ecstasies at the sight of such capital provisions, and has given us a dish this evening worthy of Brillat-Savarin. Indeed the

* Kalat Jaber, besieged in 1146 by Zengui, ruler of Mosul. Ho was assassinated, and his army retired. Jaber sustained several other sieges. See Abulfeda (Recueil des Historiens des Croisades); Benjamin of Tudela (Charton, Voyageurs Anciens ot Modernes). 
francolin seems to realise the poet's dream, who wrote,

"If the partridge had the woodcock's thigh It would be the best bird that ever did fly."

Besides these birds, of which another brace was brought to bag, Wilfrid got three or four rock pigeons, than which there is nothing better for the cooking pot. So we are now in clover." 


\section{-}

Intatis

1

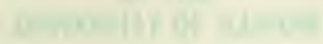




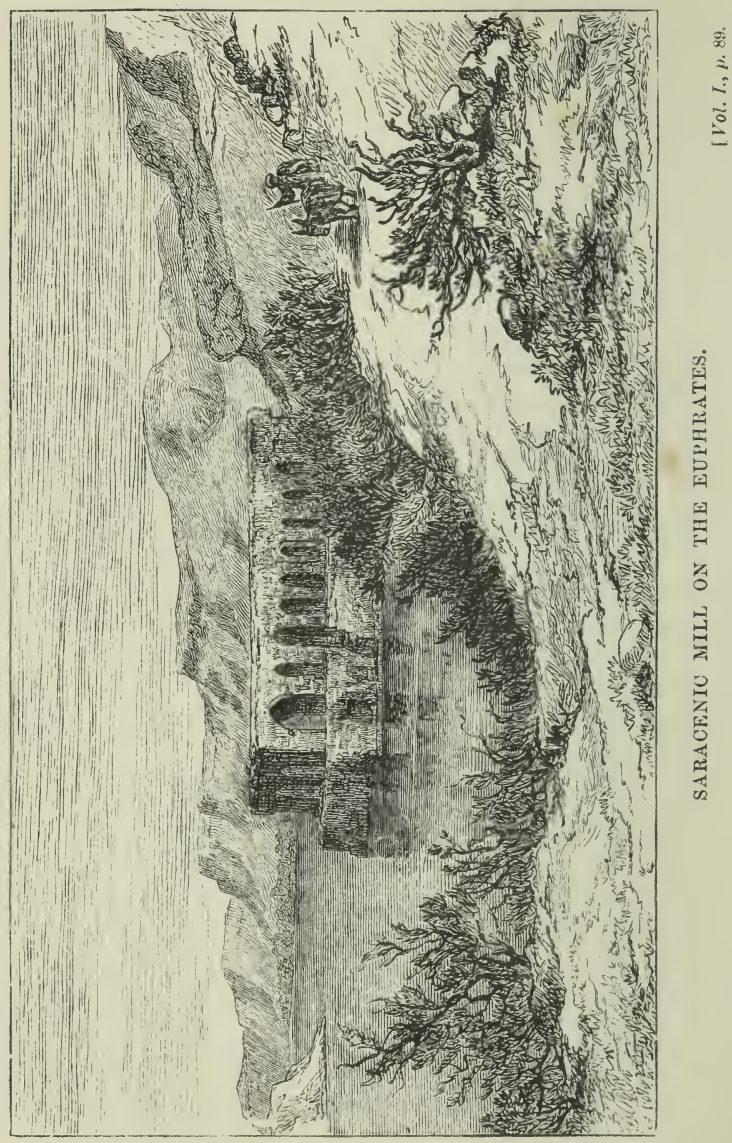




\section{CHAPTER VII.}

"Now the hungry lion roars,

And the wolf behowls the moon."

Lion district of the Euphrates-The Afuddli hunters-A Bedouin Barnum-The Kaimakam of Rakka-A wild ass-Sport in the tamarisk jungle-A wonderful horse-We arrive at Deyr.

"WE have been riding to-day along a narrow track between the cliff, which is here very abrupt, and composed in part of white marble, and a dense jungle of tamarisks, overgrown and matted together into huge thickets by brambles and honeysuckles. This seems to be some miles deep, and is said to be much frequented by wild beasts. It was just here that, three years ago, a Bedouin of the name of Bozán was killed and eaten by a lion. The lion of the Euphrates, or Babylonian lion, is not usually a dangerous beast; but every now and then there is one, which, having accidentally tasted human flesh, becomes a man eater, just as tigers do in India. These are much feared by the Arabs; and, on this particular occasion, the friends of the man killed seem to have behaved with great cowardice. They were Khryssa Arabs, an Ánazeh tribe, and were riding home one evening, in a party of half a dozen, 
when they observed a lion following them. Bozán was the only one of the party with fire-arms, the rest carrying the usual Ánazeh lance; and he, out of bravado, fired his pistol at the lion, who growled and disappeared; and the party went on their way, without hurrying or indeed thinking anything more of the matter; but, about half an hour later, it being then nearly dark, the Arabs heard a shriek, and found that Bozán, who was riding last as they were going along the narrow track in single file, was missing. They were frightened, and, without more ado, galloped away. In the morning however, they returned to see what had happened, and found the remains of their companion's body about fifty yards inside the jungle. I was rather glad when we were well out of this disagreeable neighbourhood, and in a more open country.

The valley was here again very broad; and there were wide grassy plains, interspersed with tamarisk bushes. In some places there were acres of land furrowed up, as if with the plough, but in reality by the wild boars, which must be very numerous. No wonder the peasants, in cultivated countries, dislike them. Here there is nothing to be injured. The sun was getting low, as we passed some ruins, Greek or Roman, which are marked on the map as Zenobia's baths. They are of flat bricks and concrete, mere bits of ruined wall, still called el Hámmam (the baths). Near these we found a camp of Afúddli Arabs, a low tribe, but interesting as 
having the reputation of being brave men and lion hunters. Their camp is peculiar and unlike any other we have seen.

The Afúddli are hardly nomades, as they only occasionally move their camps, and never leave this jungly district of the river. They have no sheep and but few ordinary cows, but keep great herds of buffaloes, on whose produce they live. The buffalo, they say, is not afraid of the lion, and so can inhabit even the thickest parts of the tamarisk wood, without danger. The herdsmen always go armed with guns, as well as short spears, and are said to be good shots. The Afúddli have no tents, properly speaking, but make themselves huts out of the tamarisk boughs, laced together while still growing, and roofed with a bit of tenting. The camp, near which we now are, is about two hundred yards inside the jungle, and is reached by lanes, or passages cut through it, and fenced with a kind of wattle made by interweaving the branches. These lanes twist and turn about so as to form a labyrinth, which it is difficult to get into or out of. The huts thus become an irregular village, connected by streets, and in front of each there is generally a small clearing of half an acre or so. We rode in just before sunset, pell mell with the cattle, which were cantering home for the night with their tails in the air. The people were hospitably anxious that we should sleep in their huts; but these were not inviting; and the open spaces in front of them 
were covered with the sharp points of underwood which had been cleared, and would have made but uncomfortable lying; besides, there was not a blade of grass there for the horses, which are now reduced to what they can pick up. So Wilfrid decided that, lions or no lions, we should sleep in the open tonight. We have chosen our bivouac on a high bank, where there is grass, and with a deep hollow between us and the jungle. Wilfrid has taken his gun and gone for a walk, while Hánna and I have been very busy getting dinner ready, -and a very good dinner, I think, it will be.

Mr. S. has quite recovered from his fatigue now. The Afúddli have been telling him how they shoot the lions. Whenever one is heard of, they try to surround him, taking their buffaloes with them, and, if they manage to wound the lion, these soon trample him to death. The Turkish Government has offered lately a reward of $£ 3$ for every skin brought into Deyr; and the people here have claimed it several times.

Only a fortnight ago they managed to kill two lions under the following circumstances: A cow had been found one morning killed and partly eaten; and, a man of a neighbouring tribe, the Súbbkha, volunteering to make the attempt, a pit was dug near the carcase and the man left in it to watch by night for the lion. He was partly covered over with tamarisk boughs, and when his friends came in the morning they found a lion sitting on 
the top of these, apparently in his turn watching the man. The Arabs fired, and then rushing in with their spears managed to kill the beast, and brought it to the little fort we passed to-day for the reward. Then, they assure us, during the following night, while the dead lion was lying in the yard of the fort, a hideous roaring was heard outside, and presently a lioness appeared and made an attempt to get inside. But the door was fast, and, after firing a great number of shots with no effect, they at last killed her too.

Both these lions were skinned and stuffed and are now being carried round among the tribes on a donkey by an enterprising Barnum, who, they assure us, is making his fortune by the show.

This is of course the Babylonian lion, whose peculiarity is that he has no mane. He is, I should think, one of the rarest of beasts.*

Sunday, January 13.-A wet and heavy fog. Got some good buffalo milk from the Afúddlis, and were off by eight o'clock. The sun rises now about half-past seren. Ali Beg, a Circassian, the new Mudír of Palmyra, overtook us this morning. He is well mounted on a handsome brown Segláwi Jedrán horse, and left Aleppo two days after we

* Three of these lions were shot from the English steamer which plies between Bagdad and Bússora, only three years since. One of them, when wounded, charged into the water, and attempted to board the boat. This happened on a part of the Tigris where there is no jungle. 
did. He is on his way to his post, to which he is just appointed by his brother-in-law, Kiámyl Pasha. He gave a heart-rending account of the night which he passed in an Afúddli hut. This is the first bonâ fide traveller we have seen on the road.

The country was much like that of yesterday until, after crossing a bit of desert to cut off a bend of the river, we came in sight of Rakka, the only inhabited place, since Jabúl. From a distance, we supposed it to be a large town, and indeed it was so once, but now there are but half-a-dozen inhabited houses. It stands on the opposite shore of the river, in Mesopotamia, and has to be reached by a ferry two miles below it. We should not have gone across but that Súliman was anxious to show us a mare there, which had a great reputation; and we were a little curious to see the place nearer. We left our horses with one of the Zaptiehs, and were ferried to the opposite shore in an unwieldy boat, something like a Noah's ark cut in two. The Euphrates is about a quarter of a mile wide at this point; and there is a sloping beach on either shore, which is unusual on the river. I thought I should have had to walk up to the town; but Súliman, in the high-handed way common to Zaptiehs, took possession of a mare and foal tethered hard by, and impressed her into our service. Wilfrid walked, and shot a good many francolins, which abound here. Mr. S. rode the sergeant's horse, which 
he had managed to bring over with him in the boat. There is some cultivation here, and we met a number of Arabs, men and women, on their way to the ferry; the former I thought very goodlooking, with regular features and teeth dazzlingly white. The women, who were driving donkeys before them loaded with brushwood and looking at a distance exactly like porcupines, stopped us to ask news of the war. "El Sultán mansír?" ("Is the Sultan victorious?") "Shuéya," we answered ("Not very"), and they burst into roars of laughter. The fact is, there is little love lost here between the Arabs and the Turks. This was when Súliman was out of hearing, or we should have said "inshalláh," the proper way of turning an indiscreet question.

Rakka was a Saracenic town, built, it is said, by the Caliph Haroun al Rashid as a summer residence. The walls only of the city are standing, with two gates, in what we call the Moorish style of architecture-that is to say, they are built of brick, ingeniously and fantastically arranged about a horse-shoe arch.* They are crumbling away at the base. All ruins seem to perish in this way, like trees, at the root, I hardly know why.

We were disappointed at finding no houses within the walls, nothing but a few tents. The Kaimakam received us with much formality, and

* Zengui, son of $\Lambda \mathrm{k}$ Sonkor, assassinated before Jaber, was buried at liakka. 
96 Bedouin Tribes of the Euphrates. [он. vi.

the usual cups of coffee, and a narghileh for $\mathrm{Mr}$. S., who conversed with him in Turkish. He was a little man, in a loose, wadded smoking-coat and worked slippers, European trousers and a fez. He had a fair complexion and rusty beard, untrimmed and very dirty. He seemed stupid and, like all the Turks in this country, supremely wretched. A little bright-eyed secretary, probably a Greek, explained to him all he was too slow to understand; for the talk was of politics and the war. After this he took us out to see the mare which had been sent for, a Seglawíeh Jedrán, own sister, they told us, to a celebrated horse we had seen at Aleppo. She was a handsome bay, but without action; and her hocks were badly capped. We had thought of exchanging the Maneghíeh with the sore back for her; but the negotiation did not proceed far. Some other mares were then driven in from below the town, and came galloping up, headed by a little wahásh, or wild ass, which had been caught as a foal. It was now a year old, and seemed tame enough till touched; then it lashed out furiously. In colour it was ruddy, with a broad dark line down the back. It had short ears, a drooping hind-quarter, and legs like a deer. The Kaimakam complained of its mischievous disposition and of a trick it had of biting the tails of the mares it was with. We asked for news of Jedáan and the Ánazeh; but nobody could give us any information, so we wished the official and his 
friends good-bye, and departed the way we had come. Once over the ferry we had a long gallop to find our caravan, which had stopped at some tents on the plain opposite Rakka.

January 14.-Hagar, who is generally "as good as gold," played us a trick this morning after she was saddled, by galloping off to some mares, which were grazing on the plain half a mile from where we - had camped. It was a brisk morning, and, I suppose, she wanted to warm her limbs, poor thing; besides, she had had a good feed of barley overnight, instead of the usual millet. Súliman and I set off in pursuit, but she would not let him get near her, and I had a good deal of cantering about too before I could persuade her to let me take the rein. This delayed us, and we made but a short day's journey, nothing more remarkable occurring than a successful stalk of pigeons, which brought eight to the bag at a double shot. We are of necessity "pot-hunters," and Wilfrid has no cartridges to waste on fancy shooting. It was a desolate day's ride, or else the sameness of the river scenery is beginning to tell on us; and we have been glad to stop at the first pleasant spot we came to early in the afternoon. This is a little different from the camps we have chosen or had to choose lately. The cliffs on the side of the valley here give place to green slopes, not unlike downs; and in the hollows of these, a little way back from the river, we found a camp of Subkha Arabs with 
their flock of lambs, which never goes far from the tents, in a circular depression, well sheltered from the wind and green as a spinach bowl. Here we have stopped, and laid our beds out on the slope, where they look most comfortable. Wilfrid is off, as usual, to the river and the tamarisk woods, where he likes to wander till it is dark. I have asked him to write a description of one of these woods. It is as follows :-

"The tamarisks are about as high as a ten years' growth of alder copse in England, and stand about as close together. They are generally open at the stem, so that you can make your way through them with a little stooping. There are paths, too, made by the wild boars, which it is easy to follow; and the ground is clear of rubbish, so that you need make no noise in walking. It is as well, before plunging in, to take your bearings by sun or wind, as the jungle is lower than the surrounding land, marking, in fact, the high water level of the river in times of flood; and you cannot often see more than a few yards bofore you. The boughs above are thick with magpies' nests, the accumulation of years, and their owners chatter and scream at you as you pass. You go forward cautiously, recollecting the wild bcast stories the Arabs told you, and at which you laugher a little while ago. Now the snapping of a twig makes you look quickly round, half expecting to see the quiet eyes of a lion glaring at you through the underwood. But this 
is soon forgotten; for you hear bircls calling, about fifty yards in front of you, apparently from the trees. The francolins are just beginning to roost; and you stop, and listen till they call again. A bird seems close to you, and yct you cannot see him; and, at last, he flutters down from a great thicket, where he had his perch, and is hidden again before you can get your gun to your shoulder. While you are looking into the tangled mass of brambles and honeysuckles around you, out jumps a pig with a great rush, and you fire without sceing him. It is just as well to miss, for if you chance to wound him, and he turns, he has you here at his mercy. Your shot, however, has probably flushed the francolin, and you get a snap shot at him as he rises. You wander on and on, still lured by the expectation of something new; and, following a fairly straight track, well trodden by the feet of pigs, you come suddenly on the river flowing silently and swiftly, a mass of turbid water, some dozen feet below you. There you see geese, if there happens to be a bit of backwater, or maybe a pelican. You are glad, at any rate, to correct your dead reckoning here by a look at the open sky; and you generally find that you are considerably out. But the sun has set, and it is time to go home, in as straight a line as you can keep. The jackals are beginning their whining chorus; and far away across the river you hear a roar. Is it a lion or a camel? Most probably the latter. On your way back, you 
come to an opening cut by the Arabs for firewood, and sit down to take breath. A bird flits noiselessly past you, and alights on the ground almost at your feet. It is joined presently by another, and, for an instant, you think they must be owls. You. jump to your feet and fire. They are woodcocks. You wait for another flight, but cannot wait long, for it is getting dark. You are afraid now of being benighted, and stumble back through the wood as. fast as you can, coming now and then upon a jackal slinking across the path. You look with some. anxiety for the watch-fire your friends will have lighted on some high ground to guide you back. The moon begins to show, and by its light, just as you are at the edge of the wood, you perceive walking parallel with you, and apparently intent on cutting you off from the open ground, a gaunt, red beast, moving swiftly through the trees. Your" heart jumps to your mouth, as it stops with a loud impatient roar, and you feel that you have been a fool to stay out so late-only an instant, and it moves on, and you recognize a belated cow hurrying back to her calf, tied up since morning in the camp where you have stopped. So, as romance writers say, you 'breathe once more,' and follow her. Then, in another minute, you are emptying your pockets, amid the 'mashallahs' of Hánna, Jurgy, and your other friends."

January 15.-In the middle of the night we were. woke by a startling clap of thunder just over our 
heads, and by the horses breaking loose and careering wildly about. Another flash and a clap almost together sent Hagar right over us; and it is lucky nobody was hurt. Then the rain came down. We thought that we were in for a regular ducking, but fortunately it did not last long enough to wet us through, and we slept on again quietly till morning. We resolved, however, to take this as a warning, and to pitch our tents for the future. They will save us, at least, from the heavy dews, which are almost as bad as rain.

At daybreak we heard cries and lamentations in the Subkha camp. A man had died in the night, and they were taking him to the top of the hill to bury him. We asked how old he was. They said "His beard was not yet white."

This has been a short day's journey; a good deal of time wasted stalking red geese, only one of which was bagged. While waiting for the bird to be blown on shore (for it fell into the river) I saw three enormous wild boars on the opposite bank, up which they presently scrambled and disappeared in the tárfa. About midday we came to some lagoons, or perhaps inlets from the river, quite covered with ducks and coots; and seeing this we agreed to halt for the day. We have been very busy putting up the tents. Ours looks very comfortable with its red lining; and the prospect of slceping in it seems an unheard-of luxury after all these nights spent out cf doors. It is just as well though, for the sky 
IO2 Bedouin Tribes of the Euphrates. [сн. v⿴.

is very threatening, and it is very cold. Wilfrid came back from exploring the lagoons and a peninsula beyond them, with ducks and woodcocks, and is so pleased with the place that we are to stay here the whole of to-morrow We saw a good-looking mare to-day hobbled, some way from any tents. She has probably been left on account of some defect by the Ánazeh, when they went south. They often do this, it appears, if for any reason their mares cannot travel, giving part ownership in them to some Subkha, Weldi, or other low Arabs. The new owner has a right to the first filly born. This mare was very like an English hunter, but with a better head. She may have been fifteen hands high.

January 16.-A nice quiet day in spite of the high wind blowing. - Wilfrid out shooting most of the time. I give his bag:- nine francolins, one duck, one teal, one pochard, and three wood pigeons. He also saw a couple of wolves and an infinite number of waterfowl, but had more walking than shooting. However, our kitchen is now in fine order. Hánna has turned out to be a capital cook, and he is very careful of the provisions given him. Our Aleppo bread still holds out well, and is eatable enough when toasted. We had it baked hard to start with, which is the best plan.

I forgot to say that yesterday we passed the graves of two Germans, murdered four years ago on their way up from Bagdad to Aleppo. They 
had started, we were told, without any baggage, but were well mounted. The people of Deyr, desirous to get their mares, followed them when they had passed through the town and waylaid them. I suppose they made some resistance; anyhow, here by the wayside their journey ended, and their lives.

I woke in the night, hearing a sound of lapping in the tent, and found a four-footed animal close to my pillow, with its nose in the milk pail. I had no time to think what it was, but caught it by the hind legs and drove it out. Some think it was a jackal, others a dog.

January 17.-A wild morning, flights of geese passing overhead at daybreak, and immense flocks of rooks and jackdaws, wheeling and clamouring, as they do in England before a storm. We were half inclined to put off our journey again, especially when rain began to fall; but the tents were soon down, and we started, wrapped in our thickest cloaks and overcoats. The road to-day led up the cliffs, and over a long tract of desert, across which the wind blew pitilessly, and presently it began to snow so thickly that we could only see a hundred yards or so in front of us. The wind was fortunately at our back. There was no track visible; and it seemed doubtful whether any of the party knew the right direction; but we came upon a shepherd who put us right, and by degrees tho storm abated, and before midday the sun struggled 


\section{IO4 Bedouin Tribes of the Euphrates. [сн. vir.}

out, and then we got down into the valley again, and halted some minutes under the lee of the cliffs. However, it was no use stopping, as we hope to get to Deyr to-morrow; and we pushed on all day till near sunset, when we came to a ruined wall at the edge of a tamarisk wood, where there were some tents and a flock of kids feeding under shelter of the wall. We were soon busy making a fire and warming, at least our fingers, if no more. I don't think I ever remember such a piercing wind, except perhaps when we were snowed up on the Shótt el Sherghi in Algeria four years ago. It was quite dark before the kátterjis arrived, and we were frozen to the bones. Now we have got the tents up and are out of the wind. There is nothing so snug as a tent in windy weather, for there are no draughts. It is nearly full moon, and the sky is clear. The tent is already frozen stiff. So are my hands.

January 18.- The water in the pail under the eaves of the tent had an inch of ice on it this morning; and a rope, which had given way during the night, still stuck out straight and stiff where it had broken. Hánna has enlivened the morning by a little theatrical scene about a piece of cord, secreted by some of the Arabs who have supplied us with milk. These are Aghedáat, another low tribe; and small thefts must, I suppose, be expected. However, Hánna insisted upon the lost article being restored, and appealed to Mr. S. 
Seeing that the matter was becoming serious, the Aghedáat began to accuse each other, and at last gave up two men as the culprits, and with them the lost cord. It was amusing to hear Hanna lecturing these poor thieves on the folly and wickedness of their conduct; and to see him theatrically fastening horse hobbles to their ancles. Súliman, more practically inclined, gave each a sound box on the ear; and there the matter ended.

These Aghedáat, it appears, have some good mares, which they get from the Anazeh; and thero had been some talk over night about an extraordinary horse of the Máneghi Hédruj breed to be seen somewhere in the neighbourhood; so when, shortly after starting, we met some men who offered to take us to see this beast, we readily agreed to go with them. The Máneghi breed, though much esteemed, is not usually handsome; but this they declared was an exception. "Máneghi ibn Sbéyel" * they kept on repeating, in a tone of tenderness, and as if tasting the flavour of each syllable; for the reverence of blood here amounts to fanaticism. We turned out of the track, and went for a mile or so through brushwood, coming at last to an open space where some women were rolling up a tent they had just pulled down. The "goodman" was away, they said, on his horse, gone to borrow

* Ibn Sbeyel, of the Gomussa, a tribe of Scbáa Ánazeh, possesses tho most estecmed strain of Mánegli IIédruj. 
106 Bedouin Tribes of the Euphrates. [сн. vir.

donkeys to move his camp with to fresh quarters. A horse of the Máneghi's nobility could not of course be used for baggage purposes. We had hardly done talking, when Mohammed appeared, driving half-a-dozen asses in front of him, and mounted on a meek-looking little black pony, all mane and tail. This was the celebrated sire of which we had heard so much; and I feel sure that the people about had a real belief in his good qualities, and could not understand why we should find fault, merely on account of his looks, with an animal so nobly bred. We did not stop long, but, excusing ourselves for our lack of enthusiasm by saying that black was not our lucky colour, we departed.

We were now determined to reach Deyr to-day, so, leaving the baggage to follow, and sending Súliman forward to announce our arrival, we pushed on. It seemed a long way to our impatience, but at last from some rising ground we caught sight of a point on the horizon which we knew must be the minaret of Deyr. A little later, we met three travellers, merchants of Bagdad, the only wayfarers except Ali Beg whom we had met with in our ten days' ride, who told us the town was close at hand. Then, as we were crossing a little plain, behold a cavalcade of horsemen advancing towards us, and in their front, an elegant young gentleman in European clothes who introduced himself as the Pasha's secretary, and delivered a polite message 
from his master entreating us to honour him with our company at the Serai, where the oxen and fatlings had been killed for us, and all things were ready. This we were not at all prepared for; and we at first hoped that some compromise might be come to in the way of pitching our tents in the Pasha's neighbourhood; but the young man was inexorable, and would hear of nothing less than an. unconditional acceptance. So we consented, and Wilfrid, rising to the dignity of the occasion, assumed all possible gravity in answering the salute of the fifteen men, who represent the military force of the Pashalik, drawn up by the roadside in our honour. Next, a deputation of the principal townsmen, on their best horses, and in fact everybody who could get up a four-footed beast, came out to escort us to the town, forming a cavalcade of some forty or fifty horsemen. These from time to time, and instigated by the young man who again led the way on his sorry nag with his trowscrs much tucked up and showing a pair of neat "sidespring boots," started to perform the fantasia, the common form of polite welcome among Turks and Arabs alike. This I need not describe. Lastly, at the first house of the town, mounted on a handsome black mule with trappings and tassels of black and gold, and attended by half a dozen servants, stood His Excellency Húseyn Pasha waiting in state to receive us. There was no refusing such noble offers of entertainment, so we are now at the Serai, not 
altogether loath, after all, to exchange our rough life out of doors for clean rooms with carpets spread, and, oh luxury ! in an inner chamber the paraphernalia of an almost Christian bed!" 


\section{CHAPTER VIII.}

"This accident may, at least, serve as a warning for us all, to let well alone."... MaBIA EdGEWORTH.

Húseyn Pasha's paternal government-The Ottoman policy in the Desert-“Divide et impera"-We are placed under surveillance, and hospitably thwarted in our design of visiting the Ánazeh-Deyr, the best market for pure Arabian horsesFirst talk of the Shammar-Their hero, Abd-ul-Kerim, his adventures and death-They threaten Deyr-A dishonest zaptieh-I fall into a well, and am rescued-Wo depart for bagdad.

Húseyr Pasha, Governor of Deyr, is a man of fifty or thereabouts, with a dignificd exterior, and decidedly handsome features, in spite of a grizzled beard and of the incvitable button which afflicts all faces in these regions. He is an Aleppine by birth, and in sympathy is an Arab rather than a Turk, being only Ottoman in so far as he represents the traditional policy of the Empire by paternally misgorerning his province. I do not say this to his discredit, for I believe him to be as honest an official as can be found between Aleppo and Bússora ; but the Turkish Government has never sanctioned any other system of administration in Arabia than one of oppression towards the weak and deceit towards the strong. This Húseyn loyally carries 
IIO Bedouin Tribes of the Euphrates. [\%н. viI.

out. In manner he has all the courtesy of the Turk joined to something of the Arab frankness, which impressed us very favourably, and made us hesitate in the final adoption of a title for him which more than once suggested itself to us, that of the faux bonhomme. I am still ashamed to say anything but what is good of a host so hospitable and a protector so lavish of kind protestations as was this amiable mutesherif; and, if it were possible to dissociate his early reception of us from the tiresome insincerity of his subsequent behaviour, I should say that he was one of the best and kindest friends we met with on our travels. A disagreeable suspicion, however, recurs, as I write, that from the first his hospitality was not altogether without motive. I sometimes fancy that, even before our arrival at Deyr, he must have had notice of the object of our journey, and received a hint to throw pleasant obstacles in our way, and that, being a shrewd man, as Orientals are shrewd, he had resolved on a little plan of action which should load us with civilities and polite attentions from the outset, and conduct us in the end with all honour and dispatch to the nearest point of his frontier. Nor is this improbable.

The Turkish Government has always been very jealous of foreign intrigues among the Bedouin tribes, whom it is their policy to keep as children in ignorance of all that passes in the outer world. It has equally been their policy to sow dissensions among them; and, as I have already described, by 
good fortune or good management, the most dangerous tribes were this winter hotly engaged in civil war. It would be a pity, the authorities doubtless thought, that so satisfactory a state of things should be interfered with by mere busybodies from Europe, who might possibly inform the Bedouins of the ill turn things had taken for the Sultan in Bulgaria, and of the denuded state of the garrison towns and military roads of Syria. "Divide and rule" was an cxcellent motto; and Europeans had before now attempted to unite the tribes against Ottoman rule, or patch up peaces between them out of foolish humanitarian motives. Moreover, any day might bring the news of a crisis in the affairs of the Empire; and England was known to have her eye on the Euphrates. What then more likely than that ours should be a semiofficial mission, to spy out the nakedness of the land? A British Consul would hardly have come so far from his post without political motive; and Mr. S. was with us. Húseyn, wise in his generation, may well have argued in this way. Only he would have becn wiser still if he could have guessed that honesty in dealing with us would be the best policy, and that, by sending us under pledge of silence to the Arabs, he would have gained all his object. The details of his plan, if plan there was, were ably carried out. His hospitality was absolute and complete, as that of any clescrt Sheykh. He would allow no word or 
suggestion of our occupying any other house but his own, or of our pitching tents and living outside the town. "That would do him too great dishonour." He had already abandoned his own apartment to us, and had hired a room for himself elsewhere. We should stay a week, ten days, a month, the whole winter, with him, and he should still be less than satisfied. He was our servant and vakil (agent) in all that we might require at Deyr, whether horses, if we wished to buy them, or mules and provisions for the road, when the time should come. But of this he would not speak. A feast was ready for us indoors, and the wind was blowing furiously down the street. Even Wilfrid allowed that our row of spending the whole winter out of doors must be broken here. "No hay rimedio." We consented, and were at once installed in our honourable captivity. Once within the walls of the Serai, we were of course under our host's eye, and nobody could come in or go out without his sanction. It would be difficult for us to communicate with the townspeople of Deyr, except through the Pasha's servants; and no agent of Jedáan's was likely to renture inside His Excellency's courtyard to give us information. Mr. S., fatigued with the journey, would be only too willing to stay quietly indoors; and we were strange to the ways and language of the place, and could not go about alone asking questions in the bazaar. All information, then, could be cooked for 
us, before being served up, and we were practically helpless. That this was the case we afterwards had ample proof. All the Sheykhs of importance have spies and correspondents in the town, who, if we had been encamped outside the town, would at once have come to us, hearing the report of our intended journey; but Húseyn, as we discovered later, gave orders to have strange Arabs carefully "consignés" at his door. It was impossible to get anyone to speak on the subject of Jedáan.

Húseyn himself was an agrecable talker, but conversed more readily with $\mathrm{Mr}$. S. in Turkish, the official language, (no employé, were he from Nejd, would speak Arabic) than in Arabic on the subject of our visit to the Ánazch. He could not recommend our even attempting it in the present state of things. War, as we knew, was raging in the Syrian desert, which was infested with gha:us, or marauding parties, of forty or fifty men each, over whom Jedáan himself had no control. From these the Pasha could of course give us no security. It was all he could do to preserve his communications with Bagdad. Moreover, Jedáan's position was exceedingly precarious. He had beaten the Roála; but these had gone to the Jôf to get help from Ibn Rashid, who might any day appear in the Hamád. The Shámmar of Mesopotamia were in arms, and sure to attack him as soon as they saw their opportunity ; and lastly, there was a split among the Sebáa themselves. Besides all this, it was too 
114 Bedouin Tribes of the Euphrates. [он. vir.

late. Jedáan was gone from Bíshari, "and who" knows where the Bedouins are, when once they move?" They were probably by this time far away south pursuing the Roála. We should do better to stay quietly at Deyr with him, the Pasha, for a month, when the Ánazeh would be coming north again, during all which time he would be our solicitous and grateful host. Then, when the tribes: had renewed their rayaman with the Government (an annual convention for trading purposes), he would, inshalláh, take us himself to Jeckáan. "Inshalláh" was all we could answer, thanking the Pasha for his kindness.

In the meanwhile, we were treated with almost royal honours. A guard of honour had orders to attend us wherever we should go, on foot or on horseback. outside the gates of the Serai; and the inhabitants of the town, little inclined as Arabs are to show respect to persons, were constrained to stand up as we passed in the streets, a rather tiresome piece of ceremony to us, who would rather have made friencis with them. We felt inclined to say, en bons princes-"Thank you, good people, for" your loyalty, but do sit down."

Our first day was devoted to receiving deputations, always however in presence of our host. First there were the town councillors, grave elderly Arabs in Bedouin dress (for here the Syrian tunic and turban are unknown), who came in barefooted, and sat uncomfortably on the edges of the Pasha's 
chairs, or on the ground, according to their rank on the "local board." From these no information could be had, except that Jedáan was "beyíd, beyícl, and" el Hamád" (far, far away in the descrt). Then there were Christians, of whom there is a population of about a hundred at Deyr, headed by their priest, a long-nosed Chaldean from Mósul, who were more familiar and more talkative. These all had gricvances. They had come from their homes at Aleppo or Mósul to make money, and had not made enough. They sought our protection for the recovery of bad debts. Then there was the army, represented by a licutenant; and a man who had farmed the taxes of last year, and could not get his arrears paid on account of the war; and women, -but here our patience was exhausted, and we begged that the rest might come another day.

In the afternoon we rode a little way from the town to exercise the horses, who scemed to be as much in want of fresh air as we were ourselves. My horse had broken out into a sort of rash caused by the hot stable, and Hagar seemed to have caught a cold. We went towards the hills, which are here about a mile back from the river, and got what view was to be had of the town. Deyr is built of mud and, like most of the villages on the upper Euphrates which we afterwards saw, stands in a dreary wilderness. The river, picturesque as it gencrally is, with its wild tamarisk woods and glades of grass, is bare and hideous wherever the 


\section{Bedouin Tribes of the Euphrates. [ni. vir.}

Arabs have made a permanent settlement. The sites also are usually the least interesting, being chosen for some agricultural advantage, an island, or a low alluvial tract near enough to the river level to be easily irrigated. The ancient cities, as we see by their remains, were, on the contrary, perched on commanding positions on the cliff; and this probably represents a difference in circumstances between the past and present dwellers in the valley. Formerly, as I imagine, the towns defied the Bedouins of the desert round them; now they pay them tribute and live on sufferance. This was certainly true till a few years back. The consequence is, the villages lie undefended and without regard to strategical position. They seem to depend on their poverty for protection. Deyr is especially uninteresting. Even the river loses its dignity there, being in fact but a narrow branch, the main channel passing on the other side of a low flat island, made hideous by rude attempts at cultivation. All is bare for miles round, except where the ground is broken by patches of ill-ploughed, illsown, ill-watered fields of barley. Nature may be hard-featured in the desert, but here it has been made repulsive, as a plain face is by painting. The town itself stands on a little eminence, its own ruins ; for there is evidence of its antiquity in the mounds and traces of canals which extend behind it, while the wilderness of graves around is that of a large city. 
Deyr has been further disfigured by the embellishments of an enterprising Pasha, who gare it, some few years ago, a grotesque imitation of a European faubourg. That is to say, a broad straight road was traced, with a barrack, a "public garden" enclosed with an iron railing, and half-adozen houses with a second story: The principal of these is the Serai. Outside the town, among the graves, if the evening is fine, women walk or sit; boys throw stones, or play at rounders and hockey, while young men ricle about cantering in eights, to break in the colts they have bought from the Anazeh, and teach them to change their leg easily. This is the only checrful sight.

Deyr is well known as a horse market, and is perhaps the only town north of Jebel Shammar where the inhabitants have any general knowledge of the blood and breeding of the beasts they possess. The townsmen indeed are but a single step removed from the Bedouins, their undoubted ancestors, and have preserved all the prejudices and beliefs common to the desert tribes almost untouched. They usually purchase their colts as yearlings, either from the Gomussa or some other of the Sebáa tribes, and, having broken them thoroughly, sell them at three years old to the Aleppo merchants. They occasionally too have mares left with them in partnership by the Ánazeh; and from these they breed according to the strictest desert rules. It is therefore, for a stranger, by 
far the best market for thoroughbreds in Asia; and you may see some of the best blood at Deyr that can be found anywhere, besides having a guarantee of its authenticity, impossible under ordinary circumstances at Damascus or Aleppo. There are, I may say, no horses at Deyr but thoroughbreds. We made several purchases, a chestnut mare, Sáadeh Togán, well-known, as we afterwards found, in all the desert round as one of the handsomest and best but thought to be barren; a three year old bay filly, Maneghíeh Slaji, which beat Hagar over a half mile, and a pony mare, also Manoghíeh, for which we exchanged the horse I had becn riding, as it was thought more convenient that we should have only mares upon our journey. All these at very moderate prices, thanks to the penniless state of the country, the scarcity of purchasers, and our friend Húseyn's kind authority. Súliman, the Turkish zaptich, negotiated the purchase of the first, which gives too good a trait of manners to be omitted. The mare belonged to a hojja, or learned man of the town, who had had her some years, but could not ride her on account of her high spirits; and who, finding that she had failed the last two years to produce a foal, was anxious to sell her.* . Súliman, without letting him know the name of the purchaser, agreed with him on a price; the money named was paid, and he was sent to hand it over to the owner. But the Turk could not find it in his heart to

* This is almost always a reason for selling. 
let him have all the money, and kept back five pounds. The hojja complained, and came to us for the mare, saying he would have her back; whereupon it was discovered that another fraud of ten pounds had been committed on ourselves, the man having, in fact, received fifteen pounds less than the sum we had given to Súliman. This tale is typical, not only of the dishonesty, but still more of the stupidity of the ordinary zaptieh. If Súliman could have been content with cheating us, nothing would have ever come to light about it; but his greediness spoilt all. The Pasha was fery grave when he heard what had happened, saying that it brought disgrace upon his house; and he made the sergeant refund the money. Súliman did this reluctantly, pleading that he had a wife and children to support. Wilfrid would have given the ten pounds to the poor man who had been cheated, but Húseyn begged that the matter might drop there. The man had had his money. So we were fain to be content, and even to forgive Súliman, who came next day with ashes on his head and a face of repentance. I am sorry we did so, as he afterwards proved quite unworthy. Dishonesty in money matters is not confined to Turkey, I fear; but less shame is attached to being found out there than with us. We afterrards discovered that the miserable sergeant had not only made this large coup about the mare, but had kept most of the small sums, mejidies and 
beshliks, which we had entrusted to him during our journey from Aleppo, as payment for milk and bread, in the places where we had stopped.

Húseyn had several horses and mares in his stables which he was proud to show us; but, except on such occasions, they never left their mangers, as he is a timid rider, and afraid to trust others on their backs. Among the rest, he had a fine Hamdani Simri, badly broken-kneed; but broken knees are a defect no one here considers of consequence. I suppose the horses who have them are thrown down as colts; for, when full grown, no Arabian ever falls, however careless he may be about tripping. During all our travels we never saw an accident of this sort. Now I return to my journal.

Sunday, January 20.-New plans. The Pasha assures us that it is quite out of the question our going to the Ánazeh at present, and proposes. instead that, as we are unwilling to stay longer than need be at Deyr, we should pay a visit to the Shammar in Mesopotamia. We are loath to abandon our original plan; but the main feature of it, the visit to Jebel Shammar, is at any rate impossible this year; for, whaterer else is doubtful, it seems certain that Jedáan cannot now go nearly so far south. Indeed we are beginning to think that the tale of the Ánazeh going there at all is untrue. For myself, I am quite as ready for the new plan, thinking that we should be doing a 
foolish thing to entangle ourselves just now in the Ánazeh disputes.

The Pasha has explained to us the political position of the Mesopotamian Shammar. They are a large and powerful tribe, indeed the only fighting tribe east of the Euphrates; and have been the rivals and enemies of the Anazeh ever since they first came into the country. Their Sheykh is Ferhán ibn Sfúk, in whose family the dignity of chief is hereditary. $\mathrm{He}$ is on good terms with the government, and has lately been made a Pasha, with an allowance from the Pashalik of Bagdad of about $£ 3000$ a year. In consideration of this, he has engaged to keep his people quiet and, if possible, to induce them to settle down as cultivators in the valley of the Tigris, giving the example himself by living at Sherghát, a place about sixty miles south of Mósul. Húseyn however thinks that there is more show than reality in the arrangement, as far as Fcrhán is concerned. It is certain that the Shammar are not at all pleased with the Sheykh's submission. They look upon him with some contempt even, as he is the son of a Bagdad woman, and talks Turkish, which he learned at Constantinople many years ago, when he was hostage there. The more independent members of the tribe seceded long ago from Ferhán, and put themselves under his half brother Abd ul Kérim, about whom we have already heard many stories. 
As Abd ul Kérim is a great hero in recent Bedouin history, I may as well put down here all we afterwards learned of him. His mother was of the Taï, a tribe held to be most noble by the Bedouins, though tributary to the Shammar; and on this account he was preferred by his people to Ferhán. He led them in all their wars; and, as long as he lived, his elder brother had no authority out of Bagdad. He appears to have been of that chivalrous type so much admired by the Bedouins, openhanded, generous and brare. He never would make peace with the Turks, and they often suffered severely at his hands. He and Jedáan had known each other as children, being of the same age, and Jedáan had been sent during one of their truces (for the Shammar and Fedáan are always enemies) to stay some months, as a sort of pledge of peace, in the tent of Abd ul Kérim's father Sfúk. Abd ul Kérim had indeed been a sort of patron of Jeckáan's in early life, having given him money and camels, and set him up, more than once, when Jedáan had got into difficulties; but afterwards the hereditary hostility of their tribes made them enemies. Jedáan, from having been a poor man of no particular account among his people, rose, through his skill and bravery, to be leader of the Fedáan, and then of the whole Ánazeh clan; and consequently, he and Abd ul Kérim were at constant rivalry and war. On one occasion, Jedáan with fifty followers was surprised and surrounded 
at nightfall by a large body of Shammar, who, as the custom is in the desert, waited till daylight to make their attack. The Fedáan had little chance of escape, and were resigning themselves to capture and spoliation in the morning, for their mares were tired and the enemy was fresh, when, in the middle of the night, a man came to them from the Shammar with a message to Jedáan from Abcl ul Kérim. He was riding a white mare; and the message was to the following effect: "Abd ul Kérim, in token of their ancient friendship, sends his own mare to Jedáan, begging that he will ride her to-morrow. She is the best in all the Shammar camp." Thus mounted, Jedáan fought his losing battle the next day, but escaped capture, thanks to Abcl ul Kérim's mare, his men being all taken prisoner's. The story takes us back to the days of Saladin.

Abd ul Kérim was a proud man, and took every opportunity of insulting and annoying the Turks, sending the Valy of Bagdad back without receiving him, one day when he came out to visit him. He was therefore looked upon as a mere outlaw at Bagdad. To this he owed his death. The circumstances, as I heard them related, were as follows:

Abd ul Kérim was in love with a cousin of his orrn, a claughter of his mother's brother, and consequently a Taï, * who was equally attached to him;

* The Taï women are reputed the most beautiful of any in the Desert. 
I24 Bedouin Tribes of the Euphrates. [cr. vir.

and he had intended to marry her; but, for some reason not explained, she was given by her father to another suitor. The girl sent a message to $\mathrm{Abd}$ ul Kérim, telling him what had happened, and begging him to take her away from her new husband. This the lover made haste to do, arriving with all possible speed, and followed by twenty horsemen. But the plot was discovered; and, when Abd ul Kérim arrived, he found the husband there with his friends, who, drawing his sword, cut the girl in pieces before his eyes, calling out to him, "You wanted her. Look, she is yours to take or to leare." What happened at that moment I do not know; but Abd. ul Kérim seems to have gone crazy for a while, and to have roamed about the country for several days destroying everyone he met. They say (but this of course is an exaggeration) that he sacked forty villages. On this the governor of Mósul sent out a large army to attack him, and he was driven south across the Euphrates, into the Móntefik country, where he took refuge with Nassr, the Montefik Sheykh, who, being on good terms with the Government, sent him prisoner to Bagdad. He was forwarded thence to Mósul, where the Pasha hanged him publicly on the bridge, like a common felon. The news of Abd ul Kérim's death spread consternation through Mesopotamia; and, for a time, the independent Shammar seemed permanently broken; and, there being no other of the Sfúk family old enough to be their leader, Ferhán regained his 
credit, and was once more acknowledged Sheykh of the whole tribe. Meanwhile the Taï woman, Abd ul Kérim's mother, a person of great dignity and influence, fled with her youngest son Faris and the rest of her belongings, into Nejd, where they remained two years or more. Now, however, they hare returned, and Faris is gradually resuming his brother's position, all the more warlike of the Shammar having joined him. But of this later.

Faris, it appears, is a young man of high spirit and of great personal attractions, "a great schemer," the Pasha says, and has succeeded in getting together a large number of followers who live independently of Ferhán and of all other control, in the northern half of Mesopotamia. He would be an interesting person to see, especially as he has probably never spoken to a European in his life. The Pasha thinks he might send a message to him proposing a visit. That would be much better than going to Jedáan, and I think it probable we shall do it. Otherwise there seems nothing possible but to go to Bagdad. The difficulty is to get started with the tribes, as without help or introduction of some sort, it is impossible to go to them. Whatever we do had better be done quickly, as Wilfrid is fretting at this life indoors.

January 21.-A new complication has arisen, and I really begin to suspect that the Pasha does 
I26 Bedouin Tribes of the Euphrates. [нH. vim.

not intend us to go anywhere but back to Aleppo. A man came in this morning with news that a band of Shammar have made a pounce on the Buggára, a small pastoral tribe occupying the left bank of the Euphrates, just opposite Deyr, and have carried off eightecn mares and fire thousand sheep. It sounds. rather like an excuse for putting off our new cxpedition; but the Pasha appears really frightened. He. talks of Deyr being sacked, as indeed it might be any day by the smallest tribe in the country, and has. sent off a messenger to Aleppo threatening to resign his post if not speedily supported by troops. He. has got just fifteen men here, including Súliman. and the others who came with us, and, though he has plenty of arms and ammunition, he cannot get any of the townspeople to come forward and help in the defonec. He has sent a message to the town council offering arms to all who will enroll themselves; but the councillors have prudently sent no. answer. I suppose they are not so frightened as thePasha. Wilfrid suggests ditches being dug across. the ends of the strects, or still better, that negotiations be entered into at once with Faris, who is only fifty or sixty miles off. It appears that it was not his men who took the Buggára shecp, but peoplefrom the south under Mijucl, one of Ferhán's sons, who are on bad terms with Faris; and $\mathrm{Mr}$. S. thinks that Faris might be induced to help the. Gorernment against his nephew, if properly applied to. 


\section{January 22. - Another story of marauders.} Míjuel, according to report, came yesterday and claimed tribute from some tents close to Deyr. Each tent had to give a carpet, a sheep, or a sack of barley. The Pasha is more than ever frightened and perplexed. Wilfrid suggests that we should go on a mission to Faris ; but this Húseyn will not hear of, without first sending a messenger. He sent for Beder Aga, the captain of the zaptichs, and told him, in our presence, to get ready for a long ride, and then wrote a letter to the effect that, "if Faris wished to gain favour in the eyes of the Government, now was his time. Deyr was just now without troops; but some were expected, and, in the meantime, Faris would do well to keep the country quiet; he would be paid for it, and would earn the Pasha's gratitude." A postscript was added, so Húscyn assured us, informing Faris of our desire to make his acquaintance and intention of paying him a visit.

Beder Aga took the letter, and then sat down, as if awaiting orders. "You understand," Húseyn saicl, "you are to take it to Faris." "Yes, Effendi." "And you are to go at once." "Yes, Effendi." "Now directly." "Yes, Effendi." "Then why don't you go?"-Beder Aga made no answer, but held out his right hand, moving the thumb and fingers suggestively, as if counting money. The Pasha was silent. "How am I to go?" says Beder Aga. "Why, on horscback, to be sure," says His Excellency. "And my wife 
I28 Bedouin Tribes of the Euphrates. [cH. vir.

and children, are they to go too?" "Of course not." "They must have something to eat then. Give me a month's pay of my arrears, and a month for each of my men." Húseyn seemed embarrassed. "Nonsense," he said, "what do you want with so much ? Take a week's pay." The captain saluted and went out in silence.

Wilfrid has been shooting to-day on a small island, and came home with a dozen francolins. He saw several boars.

January 23.-I have just had a wonderful escape. We were all riding quietly down the high street of Deyr this morning with two zaptichs following; when, without the slightest warning, and in view of everyone, I disappeared, mare and all, into the ground. It was like the stories of people being swallowed up in earthquakes. I had no time to think or to call out. Down we went with the soil from the street above pattering on my head, as it seemed to me, into the bowels of the earth. It was a well which Omar Pasha, in his modern improvement of widening the street, had lightly bridged over with planks, and left, a pitfall for the unwary. The planks had rotted away and we fell through. Fortunately the well was not dcep, and the recent rains had filled it with mud. With my arms stretched up, I could just reach the hands which were stretched down to me from above, and was out in an instant. With the mare it was a more difficult matter. Poor beast, she was wedged 
so tight that she could not even struggle, and had to wait there an hour or more before she could be dug out. A sloping way was made to the bottom of the well, and then ropes were passed round her, and she was dragged up the incline by main force. When untied, she jumped to her fect and neighed, having till then made no attempt at struggling. A human being could not have shown greater scnse. In the midst of our anxieties, the good Pasha arrived, shaking his head ruefully with an expression of being dreadfully shocked at such an accident having occurred under his jurisdiction. "Wah, wah, wah!" he repeated, holding up his hands "Oh dear, oh dear, oh dear !"

The Pasha's house is certainly very well ordered. He has a capital butler and a capital cook, and all his other servants are attentive and polite. The stable is liberally provided with all that horses can want, and our mares are getting fat and frisky. We keep them out of doors, in spite of the cold weather, snow and rain, much to the horror of the headgroom; but they certainly do better so when well clothed, and ours have three blankets, the outer one reaching to the heels. In travelling it does not do to let beasts slecp out of doors one night and in the next. The open air is always best for them; but they ought, except in very hot weather, to be thickly clothed. Want of sleep at night makes horses thin sooner than want of food. Besides the blankets, our mares have coats of their 
I30 Bedouin Tribes of the Euphrates. [сн. viा.

own a good inch long, and we never clean or dress them in any way. They look rough, but they keep in health.

January 24.-Beder Aga has not returned, if he ever went, nor has the Pasha alluded in any way to his message to Faris. I think the whole thing was, perhaps, a mystification, to turn our attention from Jedáan and the Ánazeh; or he may have repented when he saw that we took the proposal seriously. Now he only talks of our going on to Bagdad, and even Mr. S. thinks this will be best. He cannot himself go further with us, as his consular district ends here. It seems an "impotent conclusion" to our vast ambitions; but we console ourselves, as the French did after the battle of Worth. "Nous reculons pour" mieux sauter." The Pasha thinks of nothing but the possible sack of Deyr and his own forlorn position far away from house and home. He has none of his family with him here, and is a true Aleppine in his horror of the desert and fear of danger. "Why, why did I leave my home?" is the burden of his complaint. "What false ambition lured me, what love of the name of Pasha? Woe worth the day, woe worth the hour when I turned my face from Aleppo and came out to die in this wilderness." We know not how to comfort him, our hearts being all in the desert and not at all in the town. He talks of packing up and going, if not speedily relieved from anxiety by the arrival 
of troops. We and our affairs are quite forgotten in this deeper grief.

January 25.-A caravan, escorted by some soldiers, has arrived from Aleppo. It will go on to-morrow for Bagdad, and we, in despair of anything better, have agreed to travel with it. We cannot stay all the winter at Deyr,-it is too terribly dull;-and we may as well occupy the time, between this and the return of the Ánazch northwards, in seeing the lower portion of the river and the city of the Caliphs. Mr. S. will at the same time return to Aleppo, promising to meet us here again the first week in March, and this time really take us to Jedáan. We are to try in the meanwhile to get to our friends, the Shammar, through Colonel Nixon's help at Bagdad. The Pasha there must have troops to send with us, if he likes to do so. It seems a roundabout way to go to work through Bagdad, which is three hundred miles away from the direction we wish to take; but I have some confidence that, when thrown entirely on our own resources, we shall manage better than now when we are under tutelage. Wilfrid, of course, has hitherto left all arrangements to the Consul, who knows the country, which he does not; but, when shifting for ourselves, we have never yet been prevented from going where we had a mind to. So we hope for the best.

Now that it is settled we are to go to Bagdad, the Pasha is most energetic in hastening our pre- 


\section{I32 Bedouin Tribes of the Euphrates. [लn. vir.}

parations of departure. We have hired two mules for the baggage and a pony for Hánna, paying a thousand piastres, $\&$, for the whole journey, half in advance. We would gladly buy beasts instead of hiring, and be independent; but we promise ourselves that luxury at Bagdad. There we shall get camels and go where we like and do what we like. The great thing now is to escape from Deyr, where we feel as in a prison.

A colonel of regulars, with twenty men, mounted on mules, has arrived from Tudmor to reinforce the garrison here; so Húseyn Pasha is happier again. He will also be able to send three or four men with the caravan, which starts to-morrow morning. We are leaving our heavier luggage here, many of the things required for our expedition to the Jebel Shammar being now unnecessary. Mr. S.'s tent too will stop here, and our own things go into two large bags we had made in England for the purpose, - just a mule load,- the tents and provisions on the second mule, and Hánna on the pony. He, Hámna, is very doleful and out of heart at the prospect of going on with us alone, and he has an attack of fever; but we must get on as we can. Súliman begs to be taken on; and, having forgiven him, we have not been able to refuse. I fear he is a bad man; but at least we know him.

January 26.-A false start. The katterjis, instead of coming at eight o'clock, came at twelve, and then only brought one mule. Wilfrid insisted 
upon the other two animals being produced, and had the baggage taken down into the yard. A deputation from the caravan waited on us, begging us to put off going till to-morrow; but Wilfrid had the luggage loaded, and then only yielded to the entreaties of our amiable host. Indeed it was too late to start at two o'clock now, in the winter ; but, without some show of determination, one might be put off from day to day for a week, before getting away. This has occupied us the whole day; and now I am too busy to write more. I feel as if I should never wish to see Deyr again. Yet we are to be here again in six weeks-inshalláh! 


\title{
CHAPTER IX.
}

\author{
"While you and I, within our cots, \\ Are comfortably lying, \\ My eye! what tiles and chimney pots \\ About their heads are flying."
}

SeA Song.

A fresh start-We join a caravan bound for Bagdad-The son of a horse-Turkish ladies on a journey-How to tether a fidgetty horse-Salahiyeh-An encampment of Agheyl-The Mudir of Abukamál-Wolves at night-Wild boars and others-The Boatswain's log-Palm groves-We arrive at Ana.

January 27.-We have left Deyr, and are once more comfortably housed, thank God, under our own tent roof! It has, all the same, been rather a trying day, though the sun was out, and we had our faces to the south. Mr. S. has left us, and we are at last thrown upon our own resources. We feel now for the first time the miserable deficiency of our Arabic; and already Súliman, relieved from the control of Consular authority, shocks us by the lightness with which he bear's his disgrace. He has assumed a patronising, half contemptuous tone, which makes us look forward to a long journey in his company with anything but pleasure. Even Hánna, the precious Hánna, looks very green and gloomy, complaining of a swimming in his head, the effect of twenty grains of quinine he took this 
morning. At any moment, we are afraid, he may break down.

The caravan with which we are travelling, consists of some thirty mules and horses laden with square bales of cotton goods, probably from Manchester, and half a score of katterjis dressed in gay Syrian tunics of red and gold, partly on foot, partly mounted on diminutive asses, which they use as a sort of extra set of legs, their own touching the ground as well, the whole led by a jaunty pony with bells on his neck, whose evidently superior breeding carries him in front under a load which might crush two animals of meaner spirit. We could see at once by his face that he was born for better things, and the poor little beast seems to feel it too, for every time we pass the caravan he makes prodigious efforts to join us, moving thereby the wrath of his masters, who decline to have the caravan put out of its pace for any one's whim. "6.A pretty beast" we remarked, the first time we went by. "Praised be God!" answered the man, completing our sentence, which to conciliate ill luck should by rights have ended so, "his father was a horse." "Ibn hosán" "the son of a horse" is a term used when the dam is less than thoroughbred, and though complimentary enough to a baggage pony, is an insulting expression when used about an animal of more pretension. A little apart from the rest of the caravan, and forming a conspicuous feature, there is a tall mule carrying an immense pair of hooded panniers, led by a 


\section{I36 Bedouin Tribes of the Euphrates. [CI. Ix.}

countryman in breeches open at the knee, gaiters, a red sash, a jacket, and a handkerchief twisted round his head, who might very well pass in Andalusia for a native arriero with his hat off, for the costume is the same. He would be called there an "hombre de confianza," for he is in charge of two Turkish ladies who sit in the panniers. They are the wife and mother-in-law of a major of regulars at Bagdad, and have undertaken this very serious journey, I am sure, without the least suspicion of what they were doing; for it is impossible to suppose that any amount of devotion to the major, could have faced the thought of a four weeks' journey, penned up in this way like fowls in a coop, and looking out from a pannier, lurching all day long like a ship at sea on a world darkened by a thick cotton veil. Or why do people say that there are no real domestic ties among Mahometans?

There are four zaptichs with the caravan besides Súliman; and one of them, Mahmoud, being an Aleppine, has made friends with Hánna. He seems a good sort of man, and has helped us with our tents and mares. We are encamped about half a mile from the village of Miéddin, in a sort of peninsula where there is grass, and where, from its position, we are not likely to have any attempt made to steal our mares. The caravan and Súliman and the rest of the zaptiehs, all but Mahmoud, are gone to spend the night in the village, and we are here at last in peace and quietness, the Mudír of the 


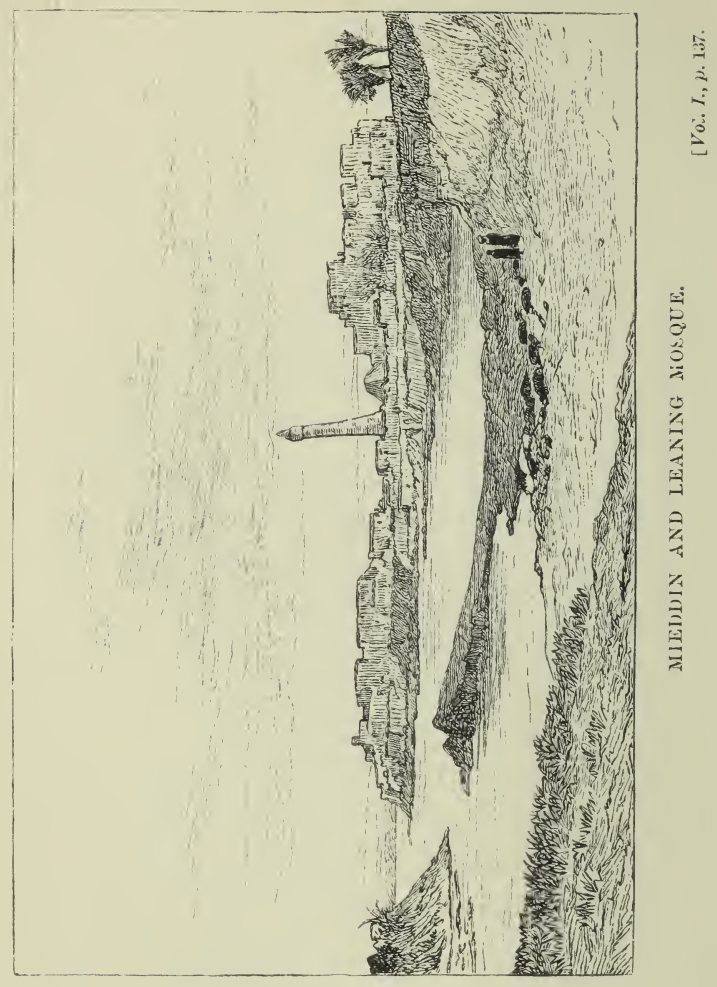


village with his friends, who came out to pay their respects, having been politely got rid of. The sky is clear, the night starlit, and we can plainly see Mieddin with its leaning minaret. Our mares are tethered close to us, with their noses inside the tent, being prevented from coming inside altogether by heel ropes. They are enjoying a huge feed of corn, after having picked up all the grass they could get for a couple of hours. We have only got Hagar and Tamarisk (my new pony) with us, the rest having gone back to Aleppo with $\mathrm{Mr}$. S. Mahmoud, the zaptich, rides a little grey colt not two years old, which is very playful and frisky, and manages to break away from its tether every five minutes. Tamarisk, too, is very fidgetty.

January 28.-A cold and frosty morning. Súliman, though he had spoken very wisely over-night about the advantages of early rising, did not appear till eight o'clock, and even then the katterjis had to be waited for. As we were at last riding away, the Mudír joined us with as much of a cavalcade as he could get together to do us honour. There was the usual fantasia, in which we especially distinguished a bay mare, an Abeyeh Sheraák they told us. It is curious that all the best gallopers are bays.

A very pretty filly was brought to us, by the way, yesterday, a "mahwardi," or rose-coloured "Kehîleh." She was so handsome that we entered into negotiations with the owner, who was probably an Aghedáat or Buggára. He could not, 
I38 Bedouin Tribes of the Euphrates. [сн. Ix.

however, tell us anything more of her breeding than that she was "Kehîleh" without any additional name, which is as much as to admit that she is not "hadúda," * so we did not pursue the matter further. This is a good instance of a fact we have already once or twice tested, namely, that Arabs, except in the towns, will not tell a falsehood about their horses' breeding. There was nothing but principle in this case to restrain the man from lying, for there were no lookers-on; and by his honesty he lost a good price for a beast he was anxious to sell. This is the more remarkable, as in all other matters, truth is the exception, not the rule, among the Arabs. $†$

To-day's march was through a cultivated district, and consequently uninteresting, except from the large flocks of sand-grouse $\ddagger$ we came across from time to time. These birds are too well-known to need description, and the variety we here find is not different from some that we have seen in Egypt and elsewhere. Wilfrid got a family shot from his mare as a large pack rose in front of him, and brought down five. Though pretty birds, they are poor eating. At about mid-day we came to a large

* Hadúd, or fit to breed from.

+ Compare practice in Great Britain and elsewhere, and see chapter on horses.

‡ Sand-grouse. Gutta. Kata, "a partridge-like bird," according to Palgrave. Compare Narco Polo's account of birds: "grands comme des perdrix, ont les pattes faites comme les perroquets, la queue comme les hirondelles, et volent moult bien." 
lagoon covered with wild-fowl, but there was no cover near it, and no chance of shooting. We wasted so much time here that the caravan passed us, and before we caught it up it had come to a halt at some Aghedáat tents, in the middle of a barley field.

This camp had probably becn there all the winter, and was disgustingly dirty, and full of noisy dogs; so, to the gricf of our followers, zaptiehs, kattcrjis, and eren Hámna, we insisted upon procecding. In vain Súliman, with a mixture of impertinence and entreaty, assured us that there was neither grass nor water on the road before us, and that, horror of horrors, we should have to sleep in the berriye (descrt). We told him to mind his own business, and to come on or not as he pleased. He followed us sulkily. Before long we came to a very nice place just under the cliff, with plenty of good grass, bushes for firewood, and a little pond where there were ducks and teal. Here we have stopped; and a very pleasant place it is, far from all sounds of man and beast. Already Hánna has got a capital fire lighted, and the sand-grouse and pigeons cooking.' The two zaptichs are in good humour again, as I hear them laughing and talking' incessantly. But for the red sunset, which threatens rain, we should have not a care in the world beyond that of digesting Hínma's immense dimner.

Jamuary 29.-Tamarisk was a great trouble to us all night, stamping and pawing and breaking away 


\section{I40 Bedouin Tribes of the Euphrates. [сн. Ix.}

in spite of all her feet being hobbled. This was perhaps on account of the jackals, wolves, and hyænas which cried and howled round us so as to frighten Mahmoud into keeping up a fire. He remarked very ruefully in the morning that it was a "terrible thing to sleep in the desert among the wolves." I confess I like them better than I do the Arab dogs and fowls, and the incessant talking of the men. My mare is certainly a very tiresome creature, and in spite of her good looks I cannot get fond of her. She is full of "tricks and subterfuges," and seems to have a fixed determination to go back to Deyr. This may account for the story we heard of her when we bought her. She was stolen about six months before and was away nearly two months, but appeared one evening at the ferry opposite Deyr, and insisted upon being taken across. She had a Bedouin pad on her back and had no doubt been among the Shammar, but had given them the slip as she is trying to do with us now. Though tied and fettered hand and foot she manages repeatedly to draw her peg; but Wilfrid has hit upon a plan which seems to be effective. It is to shackle the fore feet and then pass the head rope loosely through the fetter before tying it to the peg. This gives her nothing fixed to pull against and she seems much disconcerted.

Towards sunrise a bitter wind rose and blew into the tent freezing us to the bone as we were packing, nor could we get off till the katterjis came, for they 
had gone back to the caravan to spend the night. This is one of the miseries of travelling with hired animals, but they shall not be let out of sight again. We had two or three hours to-day of descrt and passed the ruins of Salahíyeh, a town of the same date and much the same size as Rakka. It has a fine gate in the middle of the west front, called the "Bab esh Sham," the Syrian Gate. Salahíyeh was probably the town where the Damascus road formerly branched off from the Euphrates, after following the river westwards from Ána. All is deserted now. On returning to the valley we found a large plain of green barley before us, interspersed with thorn bushes, which the Arabs had not thought it necessary to clear away. Across this we went for a mile or so without following any track. Indeed, the path we have so long pursued has now disappcared, except in places where there is a narrow passage between rocks or some other natural feature which compels the few travellers to tread in each other's footsteps. In many places, too, the track has been broken into by the river, and an incautious person going along it in the dark might very well be led, before he knew what he was doing, over the bank, which is very abrupt, and into the river. This portion of the valley is much the most thickly inhabited and the best cultivated that we have seen yet. After the barley ficlds we found ourselves in a sort of open wood of large tamarisks, each tree growing on a separate mound of sand. It 
is difficult to know whether the mound causes the tree or the tree the mound. We found some Agheyl encamped here with their camels, and stopped to drink coffee with them, which, as usual, they hospitably offered. They were on their way from Bagdad to Aleppo.

The Agheyl are a peculiar race (perhaps I should say tribe), for they are pure Arabs, though not "noble," whose head-quarters is Bagdad. They never seem to stay much at home, but travel backwards and forwards on the great caravan roads. They go very slowly, so as not to tire their camels, eight to ten miles a day, and carry goods "à très petite vitesse" between the towns. They have the reputation of immaculate honesty and seem good friends with everybody, townsman, Turk, and Bedouin. They do not carry tents, but pile their camel loads in a circle at night and sleep inside. They are cheerful, good-natured people and very hospitable. They leave their women and children at home at Bagdad, and only the men travel.

We passed through the wood till the sun was getting low, and still there was no sign of ÁbuKamál, where we were to pass the night. If the katterjis had been with us, we should have stopped and camped where we were, but now that the track had ended we did not care to risk missing them altogether by waiting for them to come up; so after Wilfrid had climbed to the top of a tell or tall mound, where there were four graves, and 
which overlooked a large tract of country, and scen nothing of the caravan, we agreed to gallop on and get into the fort before dark. Wilfrid had caught sight of it about three miles off in front of us. This we did, and had a delightful gallop, Tamarisk keeping up with Hagar much better than I had expected. The zaptiehs were soon left behind, and in about a quarter of an hour we found ourselves at the fort of Abu-Kamál. The man in charge, who has the rank of Mudír, reccived us with much amiability, and immediately had a lamb caught for us and slain. He took us on to the roof, and tried to make us come inside a little pepper-pot of a turret where he lived and in which a huge fire had been lit. We proferred stopping outside and lying down on the roof, where we were soon sound asleep, for we have had a very long march to-day. When we woke, it was nearly dark, and the moon and stars were out. Hánna had arrived with some rugs, and his cookingapparatus, which never leaves him. There is no wind, and we have got a candle on the terrace, so that I can write; and now dinner is ready, three dishes, all made of the same lamb, while our host, who will not sit down, stands shivering by to wait on us. The night looks frosty, but the katterjis are announced, so we shall have our beds and not be obliged to take refuge in the turret.

January 30.-These forts on the Euphrates all consist of a square courtyard enclosed by a mud 


\section{I44 Bedouin Tribes of the Euphrates. [сн. Ix.}

wall twelve feet high, and without other opening to the outer world than a single gateway. Inside are low rooms along three sides, used by the zaptichs or by travellers, the flat tops of which make a terrace, where there is generally an upper chamber like a box in which the head man lives. From this he looks down on all the country round, and spends his time watching for caravans which do not come. A dull life. Our host informs us that after all the Ánazeh are still in his neighbourhood only two days off! So we have been befooled by the Pasha. He tells us, too, that Jedáan passed by here quite lately, with one hundred and fifty horsemen, coming back from across the river, where he had been on a camellifting raid against the Shammar. It is very provoking, and too late now to change our plans.

Our road to-day was through a pleasant country, no more cultivation or inhabitants of any kind except birds and beasts, - great ponds surrounded with brushwood, where Wilfrid got some shooting. One drive which I made on Tamarisk was especially successful, producing five ducks of different sorts. This is much the nicest part of the whole river, and would be a capital place to make one's headquarters for a shooting excursion, as there are pools and marshes with plenty of geese, ducks, snipes, and other aquatic birds, while the big tamarisk woods are full of francolins, woodcocks, and wild boars. Wilfrid saw several of these, and had a 
snap shot at a wolf, who went away with a broken leg.

It is a great comfort to have got rid of the caravan, which stayed behind somewhere yesterday. We are now encamped at a place called Gáyim, where there is a little stream of running water (the first we have crossed) and a nice open plateau of grass above it, with a fine view of the river and of the tamarisk wood below. There is another guardhouse at a little distance, to which we have sent for corn. The guard-houses on this side of Deyr are most of them still garrisoned in spite of the warthat is to say, they contain two or three zaptichs each, and it is considered prudent to encamp more or less in their neighbourhood, as there are ghazús (marauding parties) about, and Jedáan is close by. The caravan itself would not, I am sure, for any consideration spend the night outside their walls; $* * *$

I was rejoicing in the solitude and beauty of the place, when lo and behold ! an immense caravan with dates from Ána, which, finding us encamped here under the protection of Súliman, has settled itself down beside us and intends passing the night. There are hardly any camels in this party, but about a hundred donkeys, which bray incessantly, almost drowning their masters' voices, and that is saying a great deal. The blessings of wood, water, and grass are dearly purchased at the expense of a night of noise and watchfulness, for we shall have 
I46 Bedouin Tribes of the Euphrates. [сн. Ix.

now to sleep with one eye open and fixed on our mares, for fear they should be stolen. The zaptiehs. are not of the slightest use as guards, for they sing one half of the night, and then sleep soundly the other half. Howerer, we must make the best of it, and Hánna has made us a capital dinner of teal soup, burghul with little bits of meat in it from yesterday's lamb, and a fowl with fried onions. I hear the howling of jackals and wolves; and doubtless the huge fires of the caravan do much to keep away wild beasts. Mahmoud, like all Aleppines, is very timorous about these, and declares that the mares see them at night whenever they look out into the dark. I now have to alter the stuffing of my saddle, which is not quite right, so I leave off.

January 31.-The donkey caravan was off this morning before we were, and its place was immediately occupied by hundreds of magpies hopping about and looking for scraps.

We have got into a new sort of country. The cliffs on the right bank of the river have entirely disappeared, and low downs intersected with ravines have taken their place, while on the opposite bank there is a fine headland marking the corner where the river, after a good many miles of nearly southerly course, takes a general direction eastwards. The valley has narrowed considerably and is not, I suppose, more than a mile across, while the tamarisk woods have disappeared, they tell us, for good. We- 
have also crossed to-day and yesterday a number of wadys leading to the river, the most remarkable being the Wady Ali. None of these had any water in them, in spite of the rainy winter we are having, and it is difficult to understand under what circumstances they can ever be rivers, though the water marks in their beds attest that they must sometimes be full. It is somewhere near this bend of the river that Colonel Chesney lost one of his steamers in a hurricane when he was surveying the Euphrates. There is a curious entry about it still preserved among the Consular archives at Aleppo. It is the account of the storm given by the English mate of the surviving stcamer, who was in charge when the accident happened. His crew was an Arab. one, picked up, I believe, at Ána. This is all I remember of it: "The windy and watery elements. raged tremenduous, prayers and tears was had. recourse to, but, being of no avail, I up anchor and. round the corner."

In the afternoon, after having again crossed a bit of desert to cut off an angle where we made a successful grouse drive, we came upon a ruined mill built out into the river. At first we could not make out what it was, as the wheels had long ago disappeared. It is probably of the Saracenic period or even later, the upper part seeming to be the most modern. It must have been used for raising water to irrigate the valley, and as I see many mills marked on the map, this is probably the first of: 
several. It is strange that one should find none in the upper part of the valley where the soil seems so much more capable of being cultivated than here, but perhaps they depended there on rain for their crops. There is no cultivation anywhere about here now, or any inhabitants. We cannot make out many of the places marked by Colonel Chesney on his map. Either he put them down wrongly, or the names have changed within the last forty years.

February 1.-A wearisome day. The desert now comes quite down to the river on both sides without any interrening space of green. We were out of sight of it most of the day, stumbling along over a most disagreeably stony tract, both the mares tired. Mahmoud's colt has quite got over his disposition to romp, and has now to be led by the bridle, as have most of the zaptiehs' horses. It was a great relief at last to catch sight of a group of palm trees, the first we have seen, peeping over the horizon and growing, as presently appeared, out of the river bed, which is here very narrow and sharply cut through the rocky desert. These were the outposts of the oasis of Ána. 'Two hours more brought us to the edge, whence. we looked down upon the river, and there lay Ána, a comforting sight indeed to weary eyes. As the view was quite unlike anything we have hitherto seen on our journey, I must try and describe it.

The Euphrates, as I have said, is very narrow here, having cut itself a way through a low line of 
limestone hills which crosses its course at right angles, and so has formed a deep winding gorge a good many miles in length. Along the bottom of this cleft the river runs in a series of rapids, and it is fringed on either side with palms. The town, which is a very ancient one, consists of a single long street of low mud houses with flat roofs, each having its little space of garden, but connected together by a continuous wall, with occasional sidealleys to the river. It is about six miles long, they say, (longer than Brighton), but we have only come through part of it as yet. Opposite the point where we first came upon the town there is a fine reach of water sweeping round a bold promontory, on which a castle has in late years been built. Ána is in the pashalik of Bagdad, and this they tell us is one of a series of castles made by Midhat Pasha's orders to protect the Euphrates road. Though modern it is not in bad taste. It figures prominently in a sketch I made, but I found it impossible to represent fairly the depth of the gorge and the extreme beauty of the dark-green palm groves against the red face of the rocks. To those who have seen Egypt, the character of the scene will be familiar.

After a seemingly interminable ricle along the main street of the town, where the inhabitants had assembled in groups to see us pass, politely returning our salutations, we came at last to an open space fronting the river, where we found a caravan already encamped. Here it was proposed that we 
I50 Bedouin Tribes of the Euphrates. [сн. гx.

should stop, and though we would rather have had the place to ourselves, we had nothing better to suggest, and so have pitched our tents under a group of palms.

The river is very fine here, and the buildings picturesque. Moreover, we are well sheltered from the wind, and though there is no grass for the mares, we have promise of straw and corn in abundance. The Kaimakam of course came to pay his respects to us, and a number of other bores not easily got rid of, but thank goodness they are gone now, and we can eat our dinners peaceably, and, as there is no fear of our mares being stolen here, we shall get a good night's rest, of which we are sorely in need. 


\section{CHAPTER X.}

BerNardo. 'Tis here.

Horatio. 'Tis here.

Marceluts. 'Tis gone.-Hamlet.

A Bedouin foray-We converse with a ghost-Engagement of Zénil Aga-We resolve to depart-The Kaimakam accompanies us-Entertained by Sotámm-A Bedouin meal-News from home.

February 2.-To-day has been one of blessed idleness. First there was a grand inspection of the mares' backs, and the saddles which have rubbed them. Hagar is looking rather wretched with a wrung wither, but I am in hopes that by shifting the stuffing of the saddle, I may have made things right for her. It has fortunately been a fine day, and the sun has been almost hot, which the mares enjoy, rolling on the sand to their hearts' content. While I arranged the saddle, Wilfrid took a walk on the hill with a young zaptich, a native of the place, who has been told off to us as guard while we are here. They came back at twelve with two brace of partridges, little birds of a pale dove-colour, like that of the rocks among which they live. They have yellow legs and orange bills, and orange eyes with black pupils. The hills were quite bare 
and desolate. As he was coming back he met a number of people running towards the top of an eminence, who informed him that a party of Ánazeh had come down and were carrying off some sheep. It is curious how little communication there seems to be between the Valley and the Desert. Except on the occasion of a foray of this sort nothing seems to be known or heard of the Bedouins outside by those who live on the banks of the river. Perhaps at other times of the year this may be different, but now the Berríye seems to be a debateable territory, where nobody goes without fear and trembling. The townspeople talk of the Desert, which is at their elbow, with all the expressions of awe and aversion which ignorant Europeans might have, who had never heard of it except as a traveller's tale.

As we were sitting by the river this afternoon watching the inhabitants coming down to perform their religious ablutions and say their prayers, we were accosted by an ancient mariner, a venerable looking man, with a long white beard and the remains of a green turban on his head. He greeted us gravely, but in a rather singular fashion, with the words "Starboard, port, goddam," and went on to explain that he knew our language, having served in Colonel Chesney's expedition forty years before. He asked with much feeling after the various officers then employed on the survey, and appeared touched at the news that his commander was still alive. He then went down 
the bank to the river, as we thought to wash like the other's, so that our conversation with him was interrupted, and when we looked for him again he had disappeared. Whether he was the ghost of one of those drowned in the hurricane of 1836, or, as is more likely, had simply swum across the river without our noticing it, I cannot say, but his disappearance struck us as mysterious.

We are rid of Súliman at last, to our great comfort and relief. He came this morning to say he could go no further with us, and to ask for the present which is usual in return for such services as he had rendered. Wilfrid gave him more than he had any right to expect; but he went away sulky and dissatisfied, and, as it seems, threw the money down in Hánna's tent, using what is called "abusive language." Hánna came in great glee to tell us this and to ask if he might keep the pieces, but we told him to leave them there. We are to be off to-morrow morning, for though the mares would perhaps be better for another day's rest, it had better be outside the town. We have been much pestered with visitors, who have come with the best intentions in the world and the politest invitations to dinner's and breakfasts; but we are really too tired to pay them all the attention they deserve. A new sergeant has come in Súliman's place, an Albanian, named Záynil, or Zénil Aga. I hope he may be a less disagreeable gaoler. 
Sunday, February 3.-A heavy storm of rain in the night; but our tent is, I am glad to say, waterproof. The katterjis, of course, found it an excellent excuse for proposing another day's rest; and the caravan, which had arrived yesterday, sent an earnest protest, in the name of the ladies in the panniers, who were too much fatigued to go on. The roads, they declared would be impassable, and the baggage was wet through and too heavy for the mules. All just and sufficient reasons, but not ones we could admit. Lastly Zénil, our new chief of the staff, in polite but decided terms, expressed his opinion that the journey should be delayed. To which we only replied by pulling the tents down and ordering the mules to be loaded. Fortune thus encouraged favoured us, for the rain, which had been falling heavily till then, suddenly ceased, and in half an hour more everything was ready and we started. I am bound to say that, from the moment the matter was settled, everybody was quite cheerful and ready to do his work. Indeed, sulkiness is not common among the Arabs. A soft word with them, or still better a merry one, quickly turns away wrath; and the old saying of people not being made of sugar, which we translated into Arabic, had full effect as an original and appropriate witticism. They laughed, and opposition was at an end.

We had not yet started when the Kaimakam joined us and most politely rode in our company 
till we were outside the town, the best part of a Sabbath day's journey, as it took us nearly two hours. The long street was muddy from the rain, and the hog-backed bridges over the water-courses which we had to cross continually, were slippery enough to justify the katterjis in their assurance of danger. But, once outside, the ground was hard enough, and the caravan, which had started because we insisted on going, had nothing more to complain of. The Kaimakam left us at the last house in the town, after having sent to its owner for a breakfast of dates, bread and milk, which we sat down on a cloak and ate. Then, with strict injunctions that we should all keep together for fear of the Ánazeh, who last night had driven off ten cows from this very place, he allowed us to proceed. Lastly, to complete our triumph, the sun came out and we had a very pleasant ride, cantering on and stopping alternately, as opportunity offered, to give our mares a bite of grass here and there while the rest of the party came up.

Zénil has excellent manners and seems anxious to be on good terms with us, giving us information about the tribes and places we are likely to pass, such as Súliman was too stupid or too sulky to offer. We were tired of the monotonous routine of travelling we have hitherto submitted to, and of depending for our society on the zaptichs and stopping each night in the neighbourhood of their guardhouses. We wished to see something new. 


\section{I56 Bedouin Tribes of the Euphrates. [cu. x.}

So when we came at about three o'clock within sight of some tents, we decided on going to them and making acquaintance with their owners. We had been all day on the high ground, and were still some miles from the river, and this is the first camp we have come to fairly out in the desert. Zénil made no objection, and led the way. It has been an interesting evening, and we perceive that it was a great misfortune to us to have travelled so long with Súliman, who was brutal and overbearing with the Arabs, and prevented our ever making friends with them. Zénil, on the contrary, is pleasant in his manners to all alike.

Our new friends are of the Jerîfa, an oldfashioned pastoral tribe, one of those which have lived on here since the days of Job, peaceful, unpretending people, and tributary of late years to the Shammar. They usually live in Mesopotamia, and have only crossed the river for the sake of better pasture. I should think they must run considerable risk here of being plundered by the bands of Ánazeh we have heard of lately; but, as they have no camels and only sheep and cows and a few second-rate mares, perhaps the Ánazeh do not care to molest them.

Our host. Sotámm, the chief man of this section of the tribe, is a great uncouth creature, with no pretension whatever to distinction (indeed, the Jeriffa are evidently a very low tribe) in looks or in manners, but withal a transparently honest man. 
He received us so boorishly that at first we thought we were not welcome, but it soon turned out that this was mere shyness and the effect of the overwhelming honour which he felt was being done him. I suppose he has never entertained so much as a merchant from Bagdad in his life; and a small country squire in Sussex, receiving an mexpected visit from the Pope or the Empress of the French, could hardly display more sense of the solemnity of the occasion than this poor man did in being host to a couple of Franjis. For at least ten minutes he was unable to say a word except to his sons or others about him, to whom he gave orders, in a loud and angry-sounding voice, to have sheep slain and firewood brought, and to his women, who were behind a screen, to make bread for dinner and to bring dates and butter instantly in a lordly dish. Then, without looking at us or answering any of our remarks, he sat down and began pounding coffee as if his life depended on the violence of the thumping with which he thumped it. In the meanwhile we had taken our seats without ceremony on a carpet, which had been hastily spread beyond the fire in the furthest corner of the tent, and were soon engaged in conversation with friends and neighbours, who had flocked in from all sides in anticipation of the feast and who, having none of the responsibility of entertaining us, were communicative enough and even curious. One young man was so familiar in his remarks that he had to 
be silenced by the rest. Presently milk was brought, and dates with fresh butter rather nastily plastered into the dish by the very evident thumbs of the women. Of this we partook, dipping the dates, as the custom is, into the butter. In the meanwhile the coffee-pounding was finished; and, the fire having been made up with a faggot of wild lavender smelling most sweetly, water was boiled in a huge coffee-pot and the coffee finally made in another, all this with the greatest possible solemnity by Sotámm himself. The coffee turned out to be excellent, but too strong to drink more of than the few spoonfuls poured out to each guest in diminutive china cups. Everyone present was treated to a portion, and then the pot was brought round to us again, and so on till the last drop was finished.

After this, Sotámm, feeling that he had done his duty, joined in the talk, which was principally kept up by Zénil, for with our stock of Arabic it is not easy to pursue the few topics of conversation far. Our host, it presently appeared, had a mare he was proud of, or rather anxious to sell, so we all got up and went outside before it was quite dark to look at her. The honest man was very noïf in this, perhaps, his first attempt at horse-dealing, praising his mare beyond any possible merits she could possess, and in a loud whisper constituting Zénil his vakíl (agent) for the price. At last she came, a little clumsy chesnut, with an ugly head and 
defective hoofs, besides the disfigurement of an immense firing operation on her flank. We had out of politeness to admire, and were fortunate enough to be able to cover our retreat from a purchase with the excuse of her want of size. This is an unanswerable argument, and Sotámm accepted it good-humouredly, though he was evidently disappointed. He then sent for a mare of his neighbour's, a Hádbeh, but no better specimen. We were afraid at first that our refusals to buy might diminish the cordiality of our reception; but this was not at all the case, and after allowing us to retire for awhile to our own tent, our host came to announce that dinner was ready.

This is the first really Bedouin meal we have made, and abominably bad it was. The sheep seemed to have been cut up with a hatchet quite independently of its anatomical construction, bones, meat, and all mangled and messed together, so that it was impossible to get at a clean-looking piece free from gristle or splinters. These had been thrown into a pot and boiled without seasoning $\mathrm{Or}^{\circ}$ other ceremony, and then turned out into a great round wooden dish a yard in diameter. Butter had next been plastered round the mass, and flat, half-baked loaves of dough set to garnish the edge of the plate, all damp and clammy and half sopped in the broth. In the middle lay the great fat tail of the sheep, a huge lump of tallow, with bits of liver and other nastiness near it. Though very 
hungry, neither Wilfrid nor I were able to make much progress with such a meal, especially as, being eaten by the fitful light of the fire only, it was impossible to pick and choose our pieces. The darkness, however, was welcome in one way, for it concealed our failure from Sotámm, who stood by watching jealously lest we should prematurely cease eating. He could not guess that our hands dipped into the dish returned empty to our mouths, - a "barmecide" meal, which did not last long, for two or three minutes seem to be the time allowed for each set of eaters. Then the dish was passed on to Zénil, Mahmoud, Hánna, and the katterjis, who as strangers came next, and then, some pieces having been set aside for the host, the remainder was put down to be scrambled for by the rest of the company, Sotámm's friends and relations. A plateful of graves would not have disappeared sooner in a kennel of hounds than this did among the hungry Jerîfa. Meanwhile Sotámm, with his sleeves turned up, set to on his own portion, wiping his dripping fingers from time to time playfully on the heads of his children, among whom he occasionally distributed a morsel. The feast concluded with our all having some milk out of a wooden bowl, and the guests then separated without further ceremony.

We are now, I am glad to say, in our own tent, where Hánna is furtively preparing a more possible meal out of the odds and ends of yester- 
day's dinner. We are alone, but not by any means at peace, for the camp is just now like an English country town on market days, sheep baaing, lambs bleating, and cows lowing, while unseen animals wander round, stumbling every instant over the tent ropes. Our outlandish tent puzzles them. But they are so tame there is no driving them away, and every now and then a mare or colt, with iron shackles clanking on its legs, comes up to make our mares' acquaintance. There seems little prospect of sleep.

February 4.-Long before sunrise the Arabs were up and the sheep and cows driven off to pasture. The camp is restored to comparative quiet for our own packing up and departure. The Jeriffa here have some of the humped cattle found in India as well as the European sort, so that this part of the river seems to mark the line of demarcation between the two breeds. The sheep all have the heavy tails of the Syrian breed, and the goats are much what they are in Italy and Spain.

Sotámm brought us milk and butter for breakfast, and we were rather curious to see whether all this hospitality was to be genuine, or whether he would expect a return to be made for it out of our pockets. But such doubts did him wrong. His only request as we went away was that we should come again; and we, as we wished him good-bye, felt really touched by his kindness, not knowing 
how to acknowledge it except by inviting him, with, his flocks and herds, to spend the summer with us in England, a form of compliment he appreciated at more than its worth. We promised if ever we. came that way again we would not pass his tent without stopping, and, mounting our mares amid a general shower of good wishes, we rode away. We have never met with more genuine hospitality on any of our travels than this. Hitherto our experience of this Arab virtue has been limited to. our purchasing the sheep, and our entertainer's: inviting himself to eat it with us. Here the feast was all his.

The river lately has been very much less interesting than it was higher up. There are now no tamarisk woods, and very few of those pretty spots. we used to find higher up for encamping. The road goes for the most part over desert, and a desert of a very disagreeable stony sort, constantly intersected by ravines. The mares, however, are quitefresh again, and, after a canter we had in the morning, refused for all the rest of the day to settle down into a stearly walk. We have halted opposite the village of Hadíseh, in a walled garden enclosing some fruit trees and plenty of grass for the horses. There are heavy clouds about, and a little rain has fallen. Hadíseh is built on an island, and is picturesque enough with palm-groves and a minaret. There is no bridge to it, and people cross the river swimming on inflated skins, just 
like the figures on the bas-reliefs found at Nineveh.

Hánna has had a fall from his pony, and has bruised his face, and it makes him very doleful; but the accident has, I am glad to say, distracted his thoughts from a pain in the side of which he has been complaining. I have been afraid more than once lately of his breaking down. What does him most good seems to be putting on mustard plasters, but he is very carcless of getting chilled afterwards, and I fear there is something serious the matter with him. I wish the weather would get warm.

February 5.-To-day we passed a large pool of warm water in a wady close to the river, and flowing into it. It was full of fish, and at the point where the warm water met the river we saw several very large ones, jumping like salmon. They may have been ten or twclve pound fish. Later we came to el Uzz, an island and village very like Hadíseh, and remarkable as being the town where Job lived so many years ago. It was easy to imagine the place unchanged. Job must have been a town Arab, as his house is spoken of, but he probably kept flocks and herds over in the Jezíreh (Mesopotamia), and perhaps spent part of the spring with them in tents, as Arabs do ; while the Sabeans who plundered him may very well have been a ghazí, such as we have just had news of. Zénil informs us that fifteen hundred sheep were driven 
I64 Bedouin Tribes of the Euphrates. Lон. х.

off a few days since from the neighbourhood of el $\overline{\mathrm{U}}_{\mathrm{z}}$, and highly disapproves the camp we have chosen to-night, which is a mile or more from the village of Jebbeh. But we are becoming callous to tales of harami, robbers, and even of ghazús. About an hour and a half before we stopped, we crossed the Wady Hauran, said, according to Chesney, to come from the Hauran mountains near Damascus. Its bed was dry. There is a threedays'-old moon to-night.

There are some mills here in working order, and some in ruins. Hánna was in despair for wood to make a fire, when the zaptiehs made a raid on one of these, and brought back part of a wheel with them-a true zaptich proceeding. It was soaking wet, but with lavender sprigs and the roots of other desert plants, burnt well enough for cooking purposes. They brought, too, some desert truffles* they had grubbed up; and Hánna, thus encouraged, has surpassed himself, giving us, Wilfrid says, a dish fit to be served by M. Henri himself, the fat headwaiter at Bignon's. These truffles are white, and much softer than the black sort. They look like potatoes, and, though not so well flavoured, are much more practically useful than the others.

February 6.-The weather has changed, but instead of growing warmer it is only colder. Oh, what a bitter wind! We left the baggage to follow as it could, and galloped on to warm ourselves, 
and have done a really long day's journey in a few hours. We met some people on foot, coming from. Bagdad, who told us that the English and another Frankish nation had joined the Sultan in his war against the Muscóv, and that thirty ships full of soldiers had been sent to Constantinople. They could not tell us who the other nation was. For about two hours we kept by the river, then alternately along desert and river, till about two o'clock we got down from the stony desert on to a very arid plain, with tracts of black sand partly under water. We noticed, as we went across this, a strange smell, like that one perceives in London when a street is being laid down in asphalt; and Zénil, who was riding with us, explained that it came from some wells of black water in the neighbourhood. Presently we came to a small stream of dingy water, the Wady Múrr, and a sort of black morass, altogether the most desolate bit of country I ever beheld, not excluding the bog of Allan. It is quite without regetation, and the plain is only broken by strange volcanic-looking mounds, like heaps of refuse. One might almost fancy oneself in the back yard of some huge gasometer. Across this we galloped, as it was capital ground for the horses, and were soon approaching a palm-grove with a small town beyond it, rising in a cone from the plain, and topped with a minaret. This is Hitt, the city, no doubt, of the Hittites, as Jebbeh, where we were yesterday, must have been the city of the 
Jcbusites. A curious old place, and more interesting than any other of the inhabited towns we have seen on the Euphrates. The black water they talk of must come from the bituminous springs I see marked on the map, and seems to be very nearly, if not quite, the same as asphalt. We see splotches of it all about the streets, while the floor of the guard-house where we are is asphalted like a bit of modern pavement. Hitt, of course, stands on the river, and from the window I can see several enormous barges coated with the same stuff. It is here most likely that Noah built his ark, and "pitched it within and without with pitch," for it is ready here at hand. This lower valley of the Euphrates is just the place where a great flood would have come, so that it is foolish, although it appears to be the fashion, to put down the account of it in the Book of Genesis as fabulous. Noah, by the light of these springs at Hitt, is quite an historic personage, and the beasts he saved with him in the ark were, of course, his domestic animals, camels, sheep, donkeys, and perhaps horses.

The extreme cold, and the fact that our baggage is far behind, has driven us into the guard-house, where we are now waiting. It is better than most of these buildings, having some pretension even to being called a khan. There are two little rooms with carpets and cushions, dirty enough, which we shail clear out as soon as we get our own things. We have made no ceremony with the Mudir, but 
have sent him away. The officials are all alike, and we are tired of them.

February 7.-A terribly cold night, in the middle of which I got up and went down into the yard as I heard the mares moving. I found that Tamarisk, who is the tiresomest animal I hare ever had to do with, had managed to get her rug off and was of course shivering in the icy wind. Horses are the least intelligent of all living creatures. For the sake of a moment's pleasure in rolling she had, without thinking, exposed herself to a whole night of discomfort, and yet people talk of the wonderful intelligence of the horse.

In the morning the violence of the wind somewhat abated, and there was a hard frost. We started the baggage early and went round with Zénil to have a look at the bitumen springs. They were half a mile or so from the town, but you had only to follow your nose to find them. The smell is not entirely caused by the gases from the water, but more from the furnaces in which the pitch is boiled after it is collected. The springs are certainly curious. They rise in craters and the water is perfectly clear at first, but as it runs off a thick black scum collects upon the top, and this is the stuff they skim off and collect. The taste of the water is disgusting, but it is not hot. There seem to have been numbers of these crater-like fountains in the neighbourhood formerly, but now most of them are extinct. We only saw one in active work. It 
bubbled up in a largish volume of water, the fountain being about twelve feet across by three $01^{\circ}$ four deep. The furnaces are set close to it, and are fed partly with tamarisk faggots from up the river, partly with the bitumen itself. A little further on we came to a hot spring steaming thickly in the cold morning air. This was of no value, they said, but as medicine, being in taste like the water at Carlsbad, and producing no pitch. Near to it there were salt pans, but not connected with the spring.

We were glad, after dawdling about looking at these things, to have the excuse of the caravan being in front of us to give our mares a gallop. This they were ready enough for, and we soon joined the rest of the party. We found them crossing a curious. piece of rocky ground which seemed to be a sort of old deposit. It was almost as smooth as glass, and lay in a square pattern like slices of cake stuffed with almonds. A couple of travellers have joined us from Hitt, one mounted on a fast-walking dromedary which moves our envy. After this the level of the plain was broken by a long gravelly ridge, or, as we found on examining it, a couple of ridges. running exactly parallel, and certainly not a work of nature. Wilfrid thought they might be an ancient double wall.* There were bushes near them and some grass, and we sat down awhile

* These, though we did not know it, were the first of the great Babylonian canals, whose remains cover lower Mesopotamia. 
sheltered from the wind, and ate our dates and bread and let our mares feed. There is a good deal of cultivation about here, indeed, I suspect we have got down to the great alluvial plain of Irák, which is said to extend across the Tigris and was once fertile enough. There are numcrous small watercourses through the fields, connected with the river for irrigating purposes, and we had some fun taking a line across these. Tamarisk blundered a good deal, but Hagar is a wonderfully good jumper, taking all the dykes in her stride, and putting down a foot in difficult places, just like an old hunter in England. Next we crossed a low ridge of gravelly desert, but the descrt now is very little. higher than the alluvial valley, and we thence caught sight of Rumády, a largish town with a. minaret standing in the middle of a broad green plain. As we were descending towards this we saw a fox which Wilfrid gave chase to and soon rode down, but he found to his vexation that his. gun was not loaded, so the fox got off. The.sky looks very threatening, and perhaps it is as well that we are to be indoors again to-night. Zénil had sent on a man to announce our arrival, and consequently we were met by a guard of homour outside the village, and escorted at once to the serai; for Rumády is an important place and actually in telegraphic communication with Bagdad and the rest of the world. There is a Kaimakam 
here, a very polite man, who puts himself "into four," to be agreeable to us. Rumády, unlike the other villages of late, has no palm trees, but stands in a large tract of irrigated corn-land. It is a new place made important by Midhat Pasha, who built the serai and barrack. The former is a really handsome building, with an immense courtyard behind it a hundred yards square. Here we are lodged in a very tolerable room, hoping that the katterjis may arrive before nightfall, as it is beginning to snow.

Friday, 8th.-Rumády. There is no chance of our getting away to day, as the snow, which Wilfrid was laughed at for predicting so far south, has fallen. The whole country is white, and very bleak and desolate it looks. When we looked out this morning we found the mares, which we had tied up in a corner of the yard so as to be out of the wind, standing in a pool of half melted slush. Poor creatures, they looked miserable enough, but are really none the worse for it, and are now very happy walking about the yard, where there is some grass to eat, and where they can choose their own shelter, and stand or lie down where they like. If it comes on snowing again we shall put them into an empty shed there is in the buildings, but the stables would only give them colds. Mahmoud the zaptich has imitated our treatment in this, seeing it succeed so well, and now always leaves his colt out of doors. 
The Kraimakam is superior to most officials we have met, and being, as I said, in telegraphic communication with the world, talks very knowingly about the affairs of Furope. He got a telegram this morning to say that peace had been made with Russia, and is in high delight about it, though he has not heard whether the terms of it are good or bad. "But then, you know," he said, "we have got the Broudogoul, and that shows it must be all right. The Broudogoul is the important thing. It was signed yesterday." When we left England people told us that the Mahometans would be very angry with England because she had deserted Turkey in the war, but this was all nonsense. Nobody in the country seems to have the least idea of our being responsible in the matter, and we have been only once or twice asked why England did not help the Sultan this year as she did formerly. The fact is, in this part of Turkey, and very likely everywhere, it is an accepted fact in public opinion that the English king is vassal to the Sultan. We have no difficulty therefore in explaining how it is that the English have not "marched" (rark) with the "Turks. "The Sultan has wished this time to fight the Czar alone," we say; and they accept the account without demur. An attempt to explain the real reason of our not fighting, even if we could give one, would not be taken seriously, and might lead to discussions best avoided. Now, however, England, they tell us, lias been called upon by the 
Sultan, and has come forward. The consequence of which seems to be this glorious peace. I suppose we shall know all about it when we get to Bagdad. The only person who declines to echo the general "inshalláh," when the peace is mentioned, is Zénil, who being an Albanian and a ferrent Mussulman, is still full of bloodthirsty ideas. He is a good fellow though, and far superior to any of the zaptiehs we have had to do with. He will have to leave us here and came to say good-bye this morning. His gesture, in first declining and then accepting the present offered him, would have made the fortune of a French actor in the character of d'Artagnan or some such hero of the great school of manners. He would willingly go on with us, but each district is jealous to have its own men employed on escort duty for the sake of the presents given by travellers. So we are to be handed over to a new officer to-morrow.

To-day has been a day of feasting, the Kaimakam hospitably stuffing us with really excellent food; dishes of stewed truffles, of a sort of celery called beymeh, and of a sort of potato, the name of which sounded like sejjer,* besides the kuléchets or Bagdad cakes (Bath buns), and Bagdad pomegranates, the largest in the world. The mares, too, have had their fill of straw and barley, so if no more snow falls we propose going on to-morrow. The evening has cleared; and I can see against the

* Apparently the same word as that which means "a tree." 
vestern sky, and perched on a high pole in the yard, a large buzzard, who would hardly go there to roost if there was any prospect of wind or bad weather.

February 9.-To-day has been the pleasantest of all our journey,-the mares ready to jump out of their skins with freshness after their day's rest and with the keen air of a frosty morning. At first the road across the plain was very slippery with ice, and then very slippery with mud as the sun thawed it; but later on we got to sounder ground and cnjoyed our ride immensely. We soon came to the Dibán or Wolf Hills, and sure enough the first thing we saw was a wolf. Wilfrid fired a long shot at him as he ran up the stecp side of the hili, and then got off his mare and left her with me while he tried a stalk, for the wolf had stopped when he got to the top. Presently I heard four rifle shots, and Wilfrid returned to tell me that he had seen two wolves just over the crest of the hill, and that he had fired at them from about a hundred yards off, while they ran backwards and. forwards trying to make out where the bullets and the noise eame from. But every shot missed. The wolves, however, had not gone far and Wilfrid proposed riding after them. This we presently did, and found them not a quarter of a mile from the place where they had been fired at, and less than that distance from us. The country on the top of the hills was a sort of table-land of fine 


\section{I74 Bedouin Tribes of the Euphrates. [cr. x.}

gravel, and seemed inviting for a gallop. So wewent after the wolves as fast as we could lay legs. to the ground. They started off when they saw us; but not fast, and looking constantly round overtheir shoulders as they went. As we rushed up to them they separated, and the one we followed then galloped in earnest. Hagar was, of course, soon far in front, skimming over the uneven ground like. a swallow, while Tamarisk laboured with me in the rear. I thought the wolf must have been overtaken, as he was only twenty yards in front of Wilfrid, when suddenly, in crossing a ravine, Hagar was up to her knees in the soft ground and almost on her head. The rain and snow had. undermined the soil, and after struggling a yard ortwo Wilfrid pulled his mare up, firing a parting shot however at the wolf, who swerved as it struck him; but the charge being only of No. 5 shot did not seriously impede his progress. In another second he had disappeared over the brow. This: chase, though unsuccessful, was great fun, and it was curious to get so near a view of a wild beast like this. I shall never forget the expression of the wolf's face as he looked round at us orer his. shoulder.

We saw several more wolves in the course of the day, one especially, which was so much occupied watching the proceedings of a flock of sheep that he allowed us to come within seventy yards of him, sitting down as we were approaching, and scratching. 


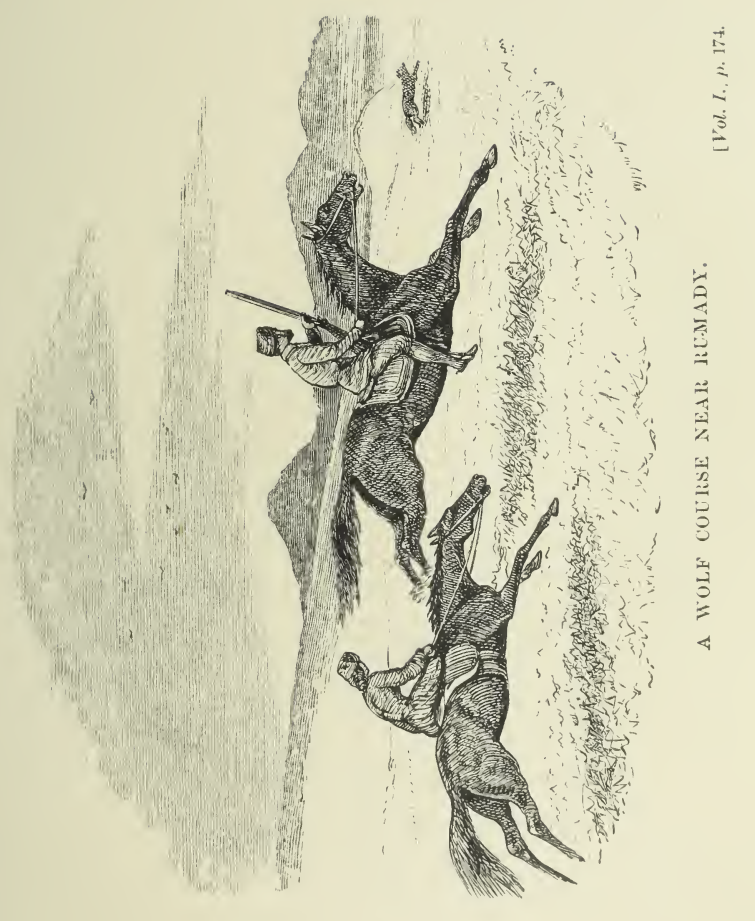




$$
\begin{aligned}
& \text { that, }
\end{aligned}
$$

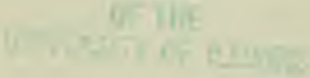


his ear with his hind foot just like a dog. Then he got up leisurely and trotted off up a ravine, where we had no chance of following him.

About two o'clock we came to the river, here again fringed with tamarisks and with a prickly brushwood called sirr. Some francolins, too, got up, the first we have seen since Ábu-Kamál, and while Wilfrid was looking for these he shot a jackal, which jumped up from under his feet. At the river we found the ferry-boat, which was to convey us at last across the Euphrates, for we are now in the latitude of Bagdad, and have only forty miles more to go, across the narrowest part of Mesopotamia, between the Euphrates and the Tigris. While waiting for the boat, the caravan came up, reminding us of the Arabic proverb, "Late and early meet at the ferry." The ladies in the litter here got down for the first time, except at night, during the whole journey. They are very amiable and polite to me; but as they talk no Arabic, and I no Turkish, we don't get on far together. They seem, as far as I can gather, to have got used to their journey, and I expect will be rather sorry to go back to the stupid life of the harem in Bagdad. They may eren some day regret the old mule and the panniers which helped them to see something at least of the world. Their dress is a sort of red and white calico sack, a black cotton veil and European boots; and when set down on the river's bank to wait for the boat, they 
looked just like a pair of bags with something alive tied up in them. The crossing was, I thought, a rather dangerous proceeding, as we were closely crammed, horses, mules, donkeys and all, the katterjis insisting upon jumping beast after beast, in, long after the boat looked as if it could not hold another creature. What with waiting and unloading the mules, and then getting the baggage stowed, we were quite two hours at the river side. The crossing itself occupied twenty-five minutes, and after all some of the baggage was left behind and did not reach us till late at night. Poor Saadún, the katterji, had managed to fall into the river.

We have encamped in a delightful spot, a hollow grown all round with sirr. We have seen a large herd of wild boar close by, and Wilfrid is away getting francolins for dinner. It is a very cold night, but still, and there will be a hard frost before morning. The name of this place is Seglawíeh.

Sunday, February 10.-Indeed it was cold. Here in latitude $34^{\circ}$, and no more than a couple of hundred feet above the sea level,-only forty miles from Bagdad, the city of the simoom and the plague, - a pail of water set inside our tent froze till it was hard as iron, and the tent itself hung stiff and rigid as a board. Wilfrid's beard, too, was hanging in icicles. Where, then, shall chilly people go in search of climate?

This morning our new sergeant of police 
announced his intention of returning home. I think the hardships of a night's watching in the chôl (desert) had been too much for him; and perhaps he reasoned that a backshísh would equally be forthcoming, whether he went to Bagdad or turned back here. But in this he was mistaken, for we dismissed him empty handed. By this time we are heartily sick of zaptiehs, soldiers, mudírs, and all the representatives of constituted government in this country, and are resolved to have no more to do with them. So, telling all who liked to go home, we started without more ceremony, and were soon rid of all our tormentors but one, who, I suppose, has come on to get the sealed paper which is necessary to prove that the escort has fulfilled its duty. Our day's ride was only the more pleasant. It lay over a series of low undulating downs of rery fine gravel thickly interspersed with grass. On these we found several small herds of gazelles, and once we put up a hare. But we are too anxious now to get on to care for sport. We hoped to see the minarets of Bagdad before night. It was certainly an agreeable bit of country, in spite of the line of telegraph posts which crosses it and tries to give it a cockney look. No special incident occurred, but we enjoyed the sunshine which came out and warmed us through, and we had more than one gallop over delightful riding ground.

It was still early in the afternoon when we came to VOL. I. 
a lake covered with a mass of water birds, pelicans, ducks, storks, and presently afterwards to a large camp of what I suppose were at last real Bedouins. At least, they had camels round them as well as sheep, and each tent had its spear stuck in the ground before it. On inquiry we found them to be Zoba Arabs, either allies or tributaries of the Shammar, and come lately from the South. We would willingly have pitched our tents with them, but it was still early, and we were foolish enough to believe the tale of our sole remaining zaptieh, who assured us that the Sheykh of the tribe was but an hour's journey further on and not far from the Tower of Nimróud, which we could already see peeping over the horizon. So instead of stopping we went on, and of course fared worse. In the first place, we have missed this, our first opportunity of secing something really Bedouin, and next, we have had after all to encamp by the tents of a very low tribe, which calls itself Amr or Ábu-Amr. But first we had a long ride of four hours instead of one, and then only accidentally hit upon our present hosts.

On leaving the lake, our course turned a little to the left, in order to avoid some swampy ground which has made the regular track impassable. In front of us was a long line of low hills, which on reaching them we discorered to be a double line of artificial mounds, just like those we saw three days ago, and we suspect that they have something 
to do with ancient Babylon. We passed through one great square space inclosed by these-it might be a couple of square miles_as if it had been a torm. Who knows? Not the zaptieh, and there was nobody else to ask. Our patience was nearly cxhausted when we again caught sight of the tower, and just before dark came upon some Arabs on donkeys, who told us the Amr camp was ncar at hand; so we cantered on, and at last have got to it. The place is called Húrnabat. It is a very dirty camp, and the people are rude and noisy. But of course the Sheykh, a little old man in rags and with a face like a ferret, lias received us with such hospitality as he can show. Only he seems to have no sort of authority over his people, who come and go in his tent, and who asked Wilfrid rude questions, as to the number of his wives, and Hánna and Mahmoud as rude ones about their religious tenets.

These Amr are evidently very low Arabs, far worse behaved than any we have come across on our road, and we wish we had stayed by the lake with the respectable looking Zoba, but it is too late now to regret our mistake. Fortunately, when we had been half an hour in the old man's tent, whose name is Massan, with a young bull tied up in one corner and a rough looking mare in the other, a very respectably dressed Arab arrived and sat down beside us. He seemed to have some authority orer the rest, and at first we thought he was a stranger, 
especially when, after a little conversation, he told us he was an Ánazeh of the Amarát tribe. We were very much astonished at this; and he ther explained that he was the head Sheykh of all these Amr, and that his grandfather had left his own people and settled here as an independent Sheykh. He certainly is quite different from all the other people, as, besides being well dressecl, he has a wellbred look and excellent manners. But we cannot understand why he has fallen foul of Mahmoud. about his religion. This Sheykh Mohammed, while we were talking, suddenly got up on to his knees and began saying his prayers and, when he had finished, cross-questioned our Mahmoud on his reasons for not doing so too, and frightened him out of his wits. The people all seem religious here, old Hassan saying his prayers outside in a loud voice, interrupted now and then by shouting at a mare or donkey, or throwing his stick at a cow.**

With us the Sheykh is very friendly. We asked to have our dinner in our own tent, so as to. be out of the noise, and he came afterwards and smoked a cigarette with us. Wilfrid gave him a tobacco bag, which he fancied, but which he made a great difficulty about accepting, insisting that if

* The half-reclaimed tribes about Bagdad are often fanatical Shías (the M[ahometan sect of Persia) while the townspeople are mostly Súnis, the true Bedouins being nothing at all. Turks, zaptiehs, and people from Aleppo would naturally be Súni. This Sheykh was no doubt a Shía. 
he did so it was on the understanding that he was to be considered as a brother. His own tent, he tells us, is a few miles further on, and he is on his way, "on business," to Rumády, and is to start very early to-morrow, as he does not wish to pass the Zoba tents by daylight. They are his enemies.

February 11.-We did not bargain at all for such a day as this has been, when we started this morning from the Amr camp at Húrnabat. We had sent on our baggage, and intended, after visiting the Tower of Nimróud which was close by, to gallop all the way to Bagdad without stopping, as our mares were still fresh. But the weather disposed of us differently. The Tower of Nimróud, as the Arabs call it, or Akha Kuf as it is written on the maps, is the traditional tower of Babel, though modern writers have transferred its site elsewhere. As seen from the Amr camp, about a mile off, it was very like the top of Mount Cervin, and hardly seemed a building at all; but as we got nearer we could see it was built of bricks. It seems to be solid; and one cannot conceive any possible use it can have been of, except, as the Bible says, to reach to heaven. It only goes a short way on the road to heaven now, being four or fire hundred feet high, including the mound of ruins on which it stands. It has nothing noble about it but its size, and serves only as a gigantic dove-cote for the blue rock pigcons which are so common everywhere 
about. We walked round it, and picked up some bits of blue pottery, and then rode on. The weather looked threatening, and I did not stop to take a sketch; but no doubt it has been drawn and described before.

The rain began to fall as we left the tower, and we went at a good pace to catch up the caravan, but that was just all we could do before the ground became so slippery from the wet, that our mares could scarcely any longer keep on their legs, even at a walk. This is the alluvial soil of Irák we have heard so much of, rich perhaps, but very dirty travelling in wet weather. From the Tower of Nimróud we had already caught sight of the minarets of Kasmeyn, a faubourg of Bagdad, and of the palm grore which borders the city; and we thought to get there in two or three hours at most, but first there was an overflowed lake to go round, and then this horrible mud to flounder through, so that more than once we were in despair of getting in at all. We could not leave the caravan, because there were places where bridges had broken down to be got over, and sloping: banks as slippery as ice to climb along, and the mules were sliding about and tumbling down every minute. At last we came to a place that seemed quite hopeless, as there was a long sort of arrête, like the crest I have heard described of Monte Rosa, to creep along, with an apparently bottomless pool of stagnant water on either side. We dismounted, and with great care got our mares across, and then 
slid them with all four fect together to the bottom of the bank; but the baggage mules, heavily laden as they were, came to the most drcadful grief, and the kattcrjis seemed inclined to give the matter up altogether. Wilfrid, however, managed at last, by wading through the mud, to rescue the animals, and then had the baggage carricd across and reloaded on the other side. This took a long while, and as it was raining still in torrents, we soon had not a dry rag left on us. In the middle of it all, arrived the unfortunate Turkish ladies in their panniers, and when they came to the "mal paso," the mule, which was an old and sagacious brute, refused to advance another yard. So the poor women, who had put on their best clothes to come smartly into Bagdad with, were bundled out into the mud, and had to trudge in their beautiful European boots across the slush, and then sit in the rain till the mule could be persuaded to follow. We had no time to wait to see how they got out of their difficulties, and I have a forlorn recollection of them huddled up under the mud bank,-clumsy and absurd figures, a pitiful sight, with their wretched bedabbled silk gowns clinging to them.

In the meantime, although cheered somewhat by the misfortunes of our neighbours, we were suffering not a little ourselves, wet as we were and chilled to the marrow of our bones. It was worse than even our entrance into Aleppo ; the wind was more searching, and we thought bitterly of the tracts of burn- 
184 Bedouin Tribes of the Euphrates. [cr. x.

ing sand in which Bagdad is popularly supposed to stand. At last the city of the Caliphs loomed through the driving rain, a grimy and squalid line of mud houses rising out of a sea of mud. Even the palm groves looked draggled, and the Tigris had that hopeless look a river puts on in the rain.

Crouched on our mares' necks, a mere mass of mire from head to foot, and followed feebly on foot by our single zaptieh, whose horse had slipped up with him and fallen heavily on his rider's leg, we entered the historical city and inquired timidly for the British residency, the house of the Consul-General. At first nobody moved or answered, but after much asking, we found a young soldier at a coffee shop, who engaged for a recompense to show us the way. First he took us to a khan, where we were to leave our mares,-for we should have to cross the river, and the bridge was shut,-a wretched yard where we tied the poor creatures up in the still pouring rain. Then we followed our guide to the river, got into a grifa, or circular boat, something like a washing-tub, and were ferried across, and at last, after what seemed an interminable trudge along a narrow cut-throatlooking lane, found ourselves at the door of the residency. Here all our troubles are over for the present, and we are sitting clothed and in our right minds close to a table spread with a table-cloth and decked with knives and forks. There are flowers on it and fruit, and on the sideboard I can see a ham. Servants of Indian type and clothed in white 
are running in and out. In a word we are in Colonel Nixon's dining-room, and ready I am quite sure both of us for all the good things he can possibly propose to set before us. There is food, too, for the mind, hungry for news from Europe :- "The Russians are at the gates of Constantinople. An armistice is already signed, and nearly the whole of European Turkey has been ceded to Russia.-Mr. Gladstone's windows broken in London.-Victor Emmanuel and his Holiness dead at Rome." 


\section{CHAPTER XI.}

"I had furnished myself with letters to a rich merchant of Bagdad."

Arabiar Nights.

Modern Bagdad a poor place-Causes of its decay-The PlagueMidhat Pasha takes down its walls and lets in a DelugeDr. Colville's view of the Bedouins-An Indian Prince-Akif Pasha's fortune-His stud-We buy asses and camels, and plan an evasion.

BAGDAD, in spite of its ancient name and of its Caliphs and Calenders so familiar in our ears, is hardly now an interesting city. Compared with Damascus or Aleppo it wants individual character, while Cairo twenty years ago must have been far more quaint and attractive. I suppose, if we had entered it from the north and by the river, we should have been differently impressed from now, coming as we have from the west, where there is nothing in the approach to give one the idea of a great city. The walls have been pulled down, and one enters by scrambling over the mounds of rubbish where they once stood, and then crossing an intermediate space of broken ground, given over to dogs and jackals and gradually abandoned by the town as it has shrunk back from its old circuit, 
like a withered nut inside its shell. One sees at once that Bagdad is a city long past its prime, a lean and slippered pantaloon, its hose a world too wide for its shrunk shanks. Within, there is little to remind one of the days of its greatness. The houses are low and mean and built of mud, and the strects narrow and unpaved as those of any Mesopotamian village. There are no open spaces, or fountains, or large mosques, or imposing buildings. The minarets are few and of inconsiderable height, and the bazaars without life or sign of prosperity. No caravans crowd the gates, and hardly a camel is to be met with in the streets. The rich merchant, like the Caliph, the Calender and all the rest, seems. to have disappeared. I don't know how it is, but these signs of decay affect me disagreeably. Bagdad has no right to be anything but prosperous, and stripped of its wealth is uninteresting, a colourless Eastern town and nothing more.

The feature of Bagdad is of course the river, the Tigris, on which it stands, and that is still beautiful. On either bank, above and below the town, there is a dense grove of palm trees with gardens under them, making an agreeable approach for traveller's who come by water, and setting off the yellow mud houses to their best advantage. Some of these are picturesquely built and cheerful enough, with bits of terrace and orange trees in front of them, but they are pretty rather than imposing, and there is an entire absence of really large 
buildings or even of important groups of houses, while the flatness of the banks and the want of streets leading down to the river prevent one's getting any idea of the depth of the city beyond. The Tigris itself is a noble river, flowing at this time of year in a rapid turbid stream and with a breadth of perhaps three hundred yards. The houses come close down to the water's edge, and there are boats and barges on it, giving it altogether a rather gay appearance, but there are no bridges but a single one of boats, which most of the time we have been here has been taken away in anticipation of a flood.

By far the pleasantest place in Bagdad is the British Residency, a beautiful old house built round two large courtyards and having a long frontage to the river. There is a delightful terrace overlooking the water, with an alley of old orange trees and a kiosque or summer-house and steps, leading down to a little quay where the consular boats are moored. Inside, the house is decorated in the Persian taste of the last century, one of the most elaborate and charming styles ever invented, with deep fretted ceilings, walls panelled in minute cabinet work, sometimes inlaid with looking-glass, sometimes richly gilt. Only the dining-room is studiously English, in deference to Anglo-Indian prejudice,-its decorations, apparently fresh from Maple's, forming a theme for admiration for the Bagdadis who come to pay their respects to Her 
Majesty's Consul-General. Colonel Nixon is hospitality itself, and his doors seem always ajar to take in unfortunate strangers like ourselves, arriving. grimed and weather worn in an otherwise inhospitable city. For there is nothing as yet in Bagdad approaching in character to an inn, not even a house of entertaimment on so poor a scale as the lokanda at Aleppo. As for the khans, they are mere empty barracks, providing nothing but a roof for the traveller and standing room for his beast. Here then in the Residency we have been living for the better part of a fortnight in absolute repose, and enjoying the good things of civilisation, as only those can who have been travelling many days in heathendom and sleeping many nights upon. the ground.

Colonel Nixon has given us much valuable information about the population, history, and general affairs of the town, some of which, at the risk of being dull, I think I ought to put down. It appears that Bagdad is in fact a decrepit, even a dying place, and that its decline, which began long. ago, has quite lately become alarmingly rapid. Its. first misfortune was its taking by the Tartars in the 13th century, * the time when so many great cities

* Marco Polo describes the taking of "Baudac," as he writes it, by the "grand Sire des Tartares qui $\Lambda$ lau avait nom." He gives a minute account of the death of the last $\Lambda$ rabian caliph which put into modern French runs as follows: "Quand il l'eut prise, il trouva une tour, appartenant au calife, toute pleine d'or et d'argent, et d'autres richesses, en si grande quantité que jamais 
in this part of Asia perished; the next, its capture by the Turks a hundred years later, and then another siege a hundred years after that. This seems to have ended its political importance, and about the same time its commerce began to decline. Like Aleppo and Scanderoon, it was half ruined by the discovery of the Cape of Good Hope, which took away its Indian trade, and now of late years the establishment of a line of steamers, from Bombay to the Persian Gulf, has deprived it of nearly all that remained. The great Asiatic caravans have finally disappeared from the gates and caravanserais of Bagdad, and are poorly represented by a home traffic of corn to Syria and of cotton goods from Manchester taken in exchange. How trifling that

on n'en vit tant rassemblé en un seul lieu. A la vue de ce trésor il fut tout émerveillé, et fit venir devant lui le calife, et lui dit: 'Calife, pourquoi as-tu amassé un si grand trésor? Que veux-tu en faire? Ne savais-tu pas que j'étais ton ennemi, et que je marchais contre toi pour te détruire? Et quand tu l'as appris, pourquoi ne t'es-tu pas servi de ce trésor et ne l'as-tu pas donné à des chevaliers et à des soldats pour te défendre, toi et la cité?' Le calife se taisait, ne sachant que dire. Alau reprit: 'Calife, puisque je vois que tu aimes tant ton trésor, je vais te donner lo tien à manger.' Il fit done prendre le calife et le fit mettre dans la tour du trésor en défendant de rien lui donner à manger ni à boire; puis il lui dit: 'Or çà, calife, mange de ton trésor tant que tu voudras, car jamais tu ne mangeras autre chose.' Et il le laissa dans cette tour, où il mourut au bout de quatre jours. Il aurait donc mieux valu pour le calife donner son trésor à des hommes qui eussent défendu son royaume et sa personne que de se laisser prendre et mourir déshérité. Co fut le dernier des califes." This was Mostasom Billah, the last of the Abasside caliphs. He reigned from 1242 to 1258 . Marco Polo dictated his travels originally to Rustician of Pisa, who wrote them in prorincial French. (See Charton, "Voyageurs anciens et modernes.") 
is we can judge by the deserted state of the Euphrates road. Already, the "rich merchants" have fled from a city which can no longer support them, and have set up shop at Bússora, which as a seaport is destined to be the capital some day of this part of the world. Even the Persian pilgrimage, which brought so much wealth to Bagdad in former days, has within the last few years, owing to the ill feeling existing between the Sultan and the Shah, been diverted to another route, so that nothing more is wanted to kill her outright but the opening of the Euphrates Valley railroad, so long talked of, when she would be left out of the track of trade to perish, like all the great cities which have preceded her.* It is melancholy to look down from the top of a minaret, as Wilfrid did, and count the empty spaces already existing inside her ancient walls. This minaret, the name of which I forget, is the one from which in former times criminals used to be thrown, and it is tall enough to command a good view. There are gaunt wildernesses in the heart of the city, where rubbish is shot, and where jackals slink about eren by daylight, and marshes which are forming here and there, through neglect in kecping: out the river. We put up a flight of tcal, only two days ago, within fifty yards of the mosque of Ali. It requires little imagination to picture to oneself

* The recent sanitary measure of forbidling the passage of Persian corpses through Bagdad on their way to burial at the tomb of IIuseyn has been equally unfortunate for tho income of the town. The Persians paid heary transit fees for their dead. 
the day when all shall be desolate, a shapeless mass' of barren mounds and heaps of crumbled brick.

Besides her loss of trade, Bagdad has been desperately treated by the plague. Dr. Colville, the resident physician here, has given me many particulars on this subject, which I think will be new to people in England. The first great visitation of this disease was in 1774 , when, if we can believe the records preserved at the Residency, nearly the whole population of the city perished. Two millions are said to have died here and at Bússora, but that figure must, one would think, include the province as well as the towns. Anyhow, the population of Bagdad has never numbered more than one hundred and fifty thousand souls since. Thirty years later, in 1804, and again nearly thirty years after that, the plague returned. In 1831, one hundred thousand perished in the town, and: the population is now stated at from eighty to a hundred thousand in all. Of these eighteen thousand are Jews, two thousand Armenian Christians, seven thousand Turks, Persians and Indians, and the rest Mussulman Arabs. The plague has existed more or less continually since. 1867, much as small-pox exists in London. It is felt most severely by the Jews, whose houses are. over-crowded and dirtily kept. Dr. Colville does. not consider it a true epidemic, that is to say, a disease communicated by the air, nor yet is it infectious in the ordinary sense. He considers that 
it cannot be caught by passing or brushing against infected people in the strects, as is commonly supposed; but that it attaches itsclf to houses and districts. It would be very foolish to frequent a plague-stricken house and dangerous to sleep in one. It creeps from house to house, being introduced into new ones by infected persons coming to them. The dirtier the house the more liable it is to the disease. For which reason, as I have said, the Jewish quarter suffers generally more than the rest. A European, living in a well-ordered house, runs very little risk, unless the infection is brought home by his servants. The Bedouins are entirely free from it; and in this the plague is in striking contrast with the cholera, which makes no distinction between town and country. About fifty per cent. of those attacked die. The plague first shows itself by a little fever which continues for a couple of days, and then by a glandular swelling on the groin or armpit. Later by high fever, delirium, and cullapse. If the swelling suppurates, the patient recovers; if not, on the fifth or sixth day he dies. There is no known remedy; but, like many diseases, Dr. Colville is of opinion that it is dying out.

Of other maladies Bagdad seems until quite recently to have been singularly free.* Standing

* The Jewish community from its long isolation and the custom of premature marriages is subject to heart disease and consumption, the latter of which the Jews hold to be contagious. They are also very short lived, but their indolent habits may account for much of this. 
in the middle of the desert it always enjoys pure air, and, although the summer temperature * is prodigiously high, is not subject to fevers or to any other epidemic than cholera, which makes no distinction between healthy and unhealthy sites. Unfortunately, however, of late years the marshes which have been forming round the town have introduced ague along with other ill results; but this deserves a more particular account.

It would appear that, besides and beyond its other misfortumes, Bagdad had the ill luck a few years since to pass through the hands of an improving Pasha, Midhat, author of the famous constitution of 1877, which is now regenerating Turkey.

That singularly unhappy statesman (unhappy, I mean, in his plans) was sent by the Sultan Abdul Aziz to try his prentice hand upon Bagdad, before being allowed his way with Constantinople and the Empire. He was an honest man, by all accounts, and sincerely anxious for his country's good, but half educated and belonging to that school of Turkish politicians, which thinks to Europeanise the Empire by adopting the dress and external forms of Europe. He seems to have been allowed almost unlimited credit for improvement and full liberty in all his. sehemes, nor can it be denied that some of them were, in their design, excellent. Only he was

* Dr. Colville, who has kept an accurate register.for several jears, informs me that he has seen the thermometer in the courtyard of his house, a well protected position, marking 122 degrees $\mathrm{F}$. 
incapable of working out the detail of what he planned, or of at all counting the cost of each adventure. They have consequently, one and all, led only to the most impotent if not the most disastrous conclusions. His first scheme was a good one. He wished to establish communication with Aleppo by the Euphrates, and in that riew built the forts we saw at Ana, Rumády and elsewhere, to protect the road, while he ordered steamers from England to navigate the river. The forts, though unnecessarily large, answered their purpose and still exist; the boats, with one exception, have disappeared, either left to rot at Bússora or never fitted out with their engines. The sole representative of the Euphrates fleet draws too much water to ascend the river except at flood, and her regular trips were abandoned. almost as soon as begun. Midhat also established, with some success, a tramway between Bagdad and its suburb Kasmeyn, which still runs. So far so good. But his next venture was not equally reasonable; indeed, it shows the unreality of his claim to be considered a serious statesman. He had heard, or perhaps seen, that the fortifications of Vienna and other towns in Europe had been pulled down, to make room for the cities they enclosed and which were outgrowing them; and, arguing from this fact that all walls were out of date, he procecded to level those of Bagdad. I dare say he thought them unsightly and feared lest they should 
remind strangers of the dark age of the world, before gunpowder and the Ottoman Empire were invented, the age of Haroun al Rashid. He seems, too, to have had a curious idea of occupying his soldiers in this work and of paying them their arrears in bricks, a rather unsaleable article, one would think, in a country where little is built and nothing at all mended. Be that as it may, the walls of the Caliphate were "removed" and the city left open to all who chose to enter, thieves, wolves and Bedouins, for it is but a few years since Bagdad was threatened with sack by the Shammar. The townsmen protested, but the thing was done. Bagdad is now as defenceless as any of the villages near it.*

Not content with this, Midhat conceived the unfortunate thought of benefiting the whole country by a huge canal, in imitation of the irrigating works once fertilising Southern Mesopotamia. Engineers were engaged, labour impressed, a special tax for the cost levied, and Midhat himself, before his term of office came to an end, had the satisfaction of opening the new canal in person, after the fashion of dignitaries in Europe. But, oh cruel fate, at the first flooding of the river, instead of

* The old palace of Ctesiphon, one of the wonders of the world, had almost shared the fate of the city walls when the foreign consuls interfered. Midhat's soldiers were already at work. Yet this is the representative of progress in Turkey, a man of letters, who writes French and English well and contributed his paper lately to the Fortnightly Review. 
a beneficent stream to fertilise the thirsty earth, behold it was a deluge that entered. Midhat Pasha with his spade let in the flood and converted Bagdad into an island, standing in a pestilential marsh and obliged at certain seasons to communicate with the outer world by means of boats. This was enough. The Porte saw the necessity of his recall, and entrusted him instead with the reorganization of the Empire. Yet, such is the power of virtue, Midhat has left behind him not altogether an evil name even in Bagdad. They narrate of him still that he went away without a shilling in his pocket and left his watch in pawn for the sum necessary to hire his horses for the journey. An honest man, in a land of dishonesty; an enthusiast, in fact, not a knave.

Of course our first thought, on arriving at Bagdad, was how to get out of it. We had no sooner changed our wet clothes and eaten our dinner, than we broached the subject of our further progress to Colonel Nixon, explaining that we had come to Bagdad not to amuse ourselves or to see sights, but in order to get introductions to the Shammar and be passed on to them with as little delay as possible. Our host readily agreed to all our plans, though he did not profess to know so much. about the Bedouins as the difference between Shammar and Ánazeh; and he most kindly offered to take Wilfrid to call upon Akif Pasha, the Valy, and promised to further our project in any way that we 
should suggest. In the meanwhile we could not do better than stay on in the Residency, and take full benefit of our rest, until all should be ready for a new start. To this we agreed, and it was settled that Wilfrid should himself open the subject of our future movements to the Pasha, as soon as he should be received in audience. It was most fortunate, however, that for some reason or other this was put off till the third day after our arrival, and by that time Wilfrid had reconsidered matters and made up his mind to dispense altogether with the Pasha's help. I am sure this is a wise resolution.

Dr. Colville has been of immense service to us in all our arrangements and enters most cordially into our plans, only laughing a little at us for what he calls our romantic ideas about the Bedouins. If we are to believe him, there are no such things as Bedouins anywhere nearer than Central Arabia, the Ánazeh and Shammar having long ago given in their submission to the Government and settled down quietly as cultivators of the soil. He knows Ferhán, Sheykh of the Shammar, Nassar, Sheykh of the Móntefik, and Abd ul Mehsin, Sheykh of the Ibn Haddal, of whom the two first are Pashas, and all three are in league with the Government of Bagdad. Of Jedáan he has heard nothing, nor of any independent Ánazeh, while Abd ul Kérim, the romantic Shammar hero, is only remembered here as a robber who was caught and hanged at Mósul some years ago. He had never heard of Faris 
till we mentioned him, and protests that we shall see nothing by going to him that we could not see ten times better with the Móntefik. He took us, however, to call upon an Indian Nawáb residing here, Ahmet Aga, a friend of his, who he believed knew something of the people we were in search of. I will describe our visit as I wrote it down at the time:

"February 13.-Ahmet Aga has a pretty house upon the river bank, nearly opposite the Residency, and we were taken there this morning by Dr. Colville in one of the Comet's* boats. The Nawáb received us on the roof, which is used as a sort of ante-room, and to which one ascends by an outer staircase, and then conducted us with much ceremony to a drawing-room on the same level, which, with another room where the ladies of his establishment live, forms an upper story to part of the house. Here we found two little boys, his sons, who seemed to be eleven and twelve years old, though we have been told that they are really older, dressed in tight-waisted frock coats, and wearing gold embroidered caps on their heads, and polished boots on their feet. They looked very shy, but had good manners. These children, it presently appeared, were married about a month ago to two little girls still younger than themselves, cousins of their own and great heiresses.

* The Comet, a Government despatch boat, attached to the Residency. 
They presently came in, shyer even than their little husbands and, one would have supposed, only old enough to be just out of the nursery, although really ten and thirteen years of age. The younger especially was very pretty. They were dressed alike, in long green dresses brocaded with gold, with gold belts, gold earrings, tiaras of moderately good diamonds, and new nose rings. Their nostrils, poor things, had just been bored for the wedding, and still looked uncomfortable. These little girls invited me to come into the inner room, to pay their mother-in-law a visit. The Begum, it was explained, did not appear in the front room when men were present. So, while Wilfrid and Dr. Colville stayed tallking to Ahmet Aga, I had to make polite speeches to the lady in Arabic, which she did not understand, and listen to her Hindustani answers, still less understood by me. As a refuge from the awkwardness of this sort of conversation, a draught-board was produced, and I was set down to play a game with the Begum, a task which I hope I performed without betraying my weariness.

"Meanwhile, Wilfrid and Dr. Colville had been more agreeably occupied in seeing the Nawáb's stud, and he has some really good horses, the best we have seen at Bagdad. When I joined them they were looking at a chestnut mare, which had belonged to Abd ul Kérim, a Kehîileh Mesénneh, nearly fifteen hands high, and they told us twelve 


\section{ин. хг.] I Relate a Tale of Abd ul Kérim. 20 i}

years old. I was interested in her on account of her former master, and began asking questions about her history and the way she had come into Ahmet Aga's possession. Suddenly Dr. Colville said, 'Here is a man who can tell you all about her,' and pointed to a grave-looking Arab who was standing by. He told me she was the mare Abd ul Kérim had been riding, when he was betrayed by Násser, Sheykh of the Móntefik; and it then turned out that this man was a Shammar and a servant of Taïf ibn Faris, the very person, it would seem, we have been wanting. Here was a wonderful stroke of good fortune, and it was soon agreed that the Arab, Nôman, should come and speak to us privately in the afternoon, and perhaps he would himself take us to his master. Of course it would be easy to get passed on from Naif to his father Faris.

"I liked the Shammar's face, and while we were looking at the chestnut mare, I could not help asking him whether he knew the story of Abd ul Kérim and the white mare he sent to Jedáan. 'Wallah,' he said, 'I remember that,' and I thought his eyes filled with tears, as well they might, considering what a hero Abd ul Kérim was with his people, and how tragical his ending. The Nawáb Ahmet Aga, too, is a friend of Naïf's, and will give us a letter to him. So Wilfrid has decided to say nothing about our journey to Akif Pasha, and to get rearly to start with Naïf's servant as soon as ever the latter's business at Bagdad 
shall be finished. This sounds exceedingly simple, and we shall be independent then of soldiers, police, Pashas and all. The first thing is to get camels; and here Dr. Colville promises to help us, although he tells us it is not the custom to buy but to hire, and that just now there are no camels nearer than those we saw with the Zoba. But he has a friend, a Christian merchant, who employs the Agheyl largely in his commercial business, and who will get us what we want, as well as a couple of trusty men to go with us as camel drivers. This merchant is under obligations to the Doctor, who saved the life of his only son last year, so that he will do all in his power to get what we want. Things are thus suddenly arranging themselves delightfully for us, without any trouble."

On the day after this visit Wilfrid called, with Colonel Nixon, on the Valy and was of course graciously received. Akif Pasha, the same who armed the Mahometans of Sofia at the outbreak of the Bulgarian massacres, is a Turk of the old school, and talks no language but his own. The conversation was therefore carried on through an interpreter, and went little further than the usual compliments, but Wilfrid describes the Pasha as a man of polite manners and apparent amiability. What little talking there was turned upon horses, of which Akif possesses the finest stud that has been got together in Bagdad for a great number of years. Neither he, nor for the matter of that anyone else in Bagdad, 
scems to have the least knowledge of the science of horse-breeding as professed in the desert, and the mistakes they make when they talk about the breeds are, to us who know, exceedingly ludicrous. I heard the other day a mare talked of as a "Kehîleh Jedrán," and the Pasha's favourite at prescnt, it appcars, is a "Kehîleh Simri" ! Akif has the reputation of bcing the most corrupt Pasha that ever ruled in Bagdad, but this is saying a great deal. He has been only eight months in office, yet, according to common report, he has already amassed $£ 50,000$ in money, besides jewelry, horses and much other wealth in kind. Let us hope that the sum is exaggerated. It is difficult all the same to believe that the sixty or seventy Arabians, which compose his stud, have been bought and paid for out of the income of the Valy's office. Indeed, I doubt extremely whether, if he should by any accident hear that I have written this, Akif Pasha would not take what I am saying as a compliment. The Turks do not connect any dishonourable idea with the acceptance of presents by men in office. They hold it to be part of their salary, just as our servants in England do the commissions they receive from tradesmen in return for patronage. The offer of a bribe, in Turkey, would hardly be resented as an insult, even by the most prudish official, while ninety-nine out of a hundred of the men in power look to such offerings as proper tokens of respect from inferiors to their superior. 
To come to a Pasha for justice with " nothing in your hand" would be to treat him cavalierly, and would imply that you thought but little of his power to help you; and it is difficult to decide, whether morality is less outraged by the acceptance of these things, without corresponding return made, or by loyally according support, as modern etiquette prescribes, to whoever brings most. Still there are certain limits to the amount of plunder allowed by public opinion, and Akif would seem to have passed these, for the people he is governing complain. It is said that the new treasurer of the mosque of Huseyn, at Meshid Ali, had to bring $£ 10,000$ to the Serai before being installed, and that every other official act or appointment, requiring the Valy's signature, has been taxed on the same scale; but after all, it is probably the Government at Constantinople which has really contributed the bulk of His Excellency's income.

In return for Wilfrid's visit, Akif sent his secretary, $\mathrm{M}_{\mathrm{r}}$. Reubeniram, with a polite message, begging that we would do him the honour of inspecting his stud, and, this being reputed so fine a collection, we readily accepted the invitation. Mr. Reubeniram is an Armenian of most polite manners and a Parisian education. He speaks French rather better than we do, and is most amiable in his attentions and desire to please. He had got ready for us a kiosque, improvised for the Shah of Persia on one of his risits to Bagdad, in the 
garden of the Serai and close to the Valy's stables. There, sitting in state upon gilt ram chairs, we spent a rery agreeable morning, while the horses and mares were paraded before us. There were fifty or sixty of them in all, fat and beautifully groomed, each led by its attendant-a really charming sight. They were brought out half a dozen at a time and marched past us in procession, each animal stopping to be shown off and to exhibit its merits. The Valy's grooms were much more expert at this than the Bedouins and country people, who had hitherto brought us horses to look at; and I am bound to say that a better looking collection could hardly have been imagined. We were asked to point out those which pleased us most, and for a moment we were afraid that Mr. Reubeniram was going to press them on our acceptance, according to Oriental custom, as a present, but before long it appeared that a more business-like transaction was in view, and that the Valy, who had just been recalled to Constantinople, is anxious to dispose of them either separately or "en bloc," and at a "terrible sacrifice." We had been so imprudently enthusiastic in our comments that, although we knew very well that none or almost none of the animals we had seen were likely to be thoroughbred, and that at best we could have no sort of guarantee of their breeding, we felt obliged to go through the form of inquiring about a fine black mare standing nearly fifteen hands two inches, which secmed the 
handsomest of the lot. Mr. Reubeniram promised that we should have all particulars sent to us, as he himself was not up in the pedigrees of the stud, and the grooms contradicted each other in the statements they made-though "Seglawi Jedrán" seems to be the usual answer made to all inquiries at Bagdad about breed. The fact is, the Bagdadis affect to despise distinctions in breeding, their own stock having long ago been crossed with the Persian and Turcoman breeds, for the sake of increased size, required by the English market in India. The present Bagdad horse, or Iráki as he is called, is a tall, powerful animal with a handsome crest and fine carriage, but, to eyes accustomed to the Ánazeh type, wants distinction. As a cavalry horse or for parade purposes, he is perhaps quite as useful as his better bred predecessor, but is far inferior to him in speed and quality. The best horses seen in Bagdad come generally from the Ibn Haddal and pass there as thoroughbred Ánazehs, although it is well known in the desert that the Ibn Haddal, from their intercourse with Bagdad, have adopted many of the tricks of the trade not tolerated by the rest of their brethren. A few, and these are probably of pure breeding, have been brought in by the Shammar, but the rest come from the Móntefik, the Delím, and other semi-felláhin tribes of the lower Euphrates, if not bred in Irák itself.

The Valy's answer was characteristic, and reliered us from any further anxiety in the matter of our 
purchase. The mare, he informed us, was from Nasser, Sheykh of the Móntefik, and belonged to a celebrated breed known among the Bedouins as "Kehîilan el Ajuz es Simri"; which was much as if in selling a flock of shecp, their owner should describe them as being of the "Rambouillet Leicester" Southdown" breed. Her price was $£ 300$.

Two days later, Akif's stud was sent to the hammer and fetched prices varying from $£ 50$ to $£ 80$, but I believe the greater part of the horses were bought in. There were hardly any bidders. A little Abéych Shcrrák, of whose breeding there wass some eridence, as she had been sent by Fcrhán, Sheykh of the Shammar, to Akif's predecessor, we should probably have purchased but for her colour, grey, which we do not like. A very handsome mottled grey, fourteen hands two inches, went for $£ 50$. He was the pick of the lot. Horses are very cheap in Bagdad just now, an ordinary animal, young and sound, fetching not more than $£ 10$. Mahmoud, the zaptich who came with us from Deyr, took back with him a four-year-old of very respectable appearance, for which he only gare seven Turkish pounds. These, however, are of course leadlishes though far better bred than their representatives at Aleppo and in the north, but it is useless to look for really thoroughbred horses at Bagdad.

I fear we have been very remiss in our sightseeing, and now we are going away from Bagdad 
without having been inside a single mosque, or having visited the site of Babylon, or made any other of the picnic excursions in the neighbourhood, except to Ctesiphon. But everybody has described that, so I forbear. The Tak-i-Kesra is the finest ruin I ever saw. No-all our time and thoughts have been employed on more practical mattersthe details of our new journey. We are going, now, into a quite unknown country, of which even Dr. Colville can tell us nothing, and where there are no villages or guard houses, or markets of any sort to supply our commissariat. Everything will have to be carried with us, bread, rice, coffee, sugar and tobacco, the last two to give away. We have also been purchasing more mashlahs, or cloaks, the conventional robes of honour, with which it is customary to invest the great men of the desert whom one wishes to propitiate, and red boots for their retainers. Nown and Shakouri, Dr. Colville's Christian friends, have been as good as their words in the matter of the camels, and Wilfrid has seen and approved the beasts they have had brought in from the country, four fine young camels, capitally matched and said to be fast walkers, at £10 a-piece, and a delúl, or she-dromedary, for occasional use in relieving Hagar of part of her duties. She is priced at sixteen shillings less than the camels, but Wilfrid thinks she will turn out as well as any of them.

Besides these, we have purchased a white ass for 
Hánna, who, as he will have to carry the cookingpots and a certain amount of provisions with him, must be well mounted. She is four years old, and stands about twelve and a half hands, walles at a prodigious pace and is warranted not to stumble. For a beast of this merit we are supposed to have bought her cheap at $£ 16$. Hanna is of course as proud as Punch at the thought of riding a white donkey, which at Aleppo is considered the ne plus ultra of fashion, being indeed the way of going abroad reserved for Pashas, Imams, and the richest of rich merchants. These donkeys are bred in el Hása, on the south-western shore of the Persian Gulf, and are brought to market at Queyt. They sometimes fetch as much as $£ 40$ a-piece, their value depending on their size, pace, and above all sureness of foot, for many of them stumble. A she donkey will fetch nearly a third more than her brother ass, because he is likely to prove a nuisance with his braying.

In all other respects we are starting, rather like babes in the wood, on an adventure whose importance we are unable to rate. It may be perfectly easy, as Wilfrid thinks, and it may be as dangerous as others would have us believe. We have after all got nobody going with us who knows anything of the Shammar or of the road more than a few miles out of Bagdad. Our Shammar friend, Nôman, Naif's servant, has turned out to be a humbug if not an actual rogue. When it came to 
really treating with him and settling matters in black and white, he backed out of it, asking the absurd price of $£ 20$ for his services, and, moreover, to be paid in advance. This was as much as admitting that he was not what he had represented himself to be. Either he is not Naif's servant at all, or he could not guarantee our safety to his master. We cannot make out what Faris's position really is. At Deyr we heard of him as quite a young man and on ill terms with his brother Ferhán. Here they talk of his having a son of twenty-five, and will not admit that there are any dissensions among the Shammar. But we shall see. On the other hand, we have secured the services of a couple of Agheyl as camel men, at the very moderate rate of sixteen shillings a-month, engaging to keep them two months and to pay half in advance. This we have readily agreed to, as all Agheyl are honest men; at least such is the popular belief.

We have said nothing to anybody, except Colonel Nixon, Dr. Colville and one other person of where we are going; and Mr. Reubeniram is under the impression that a shooting excursion to Babylon is contemplated. The one other is a distinguished personage and necessary to our plan. $\mathrm{He}$ is the good old Nawáb Ikbálet Dówlah, formerly King of Oude, and now living in exile at Bagdad. With him we have made great friends, and he is to aid in our plan of evasion by inviting us to his country 
house at Kasmeyn, whence, without any ceremony or asking leave of Pasha, secretary or chief of police, we shall slip away into the desert and trust to Providence for the rest. 


\title{
CHAPTER XII.
}

\begin{abstract}
"Il finissait à peine de parler, que les principaux habitants du village, réunis chez lui pour nous voir, commencèrent à nous raconter des histoires effrayantes. L'un nous dit qu'un colporteur, venant d'Alep et allant au désert, avait été dépouillé par les Bédouins, et qu'on l'avait vu repasser tout nu. Un autre avait appris qu'un marchand, parti de Damas, avait été tue. Tous étaient d'accord sur l'impossibilité de pénétrer parmi les hordes de Bédouins, et cherchaient, par tous les moyens possibles, à nous détourner d'une aussi périlleuse entreprise. Je voyais $\mathrm{M}$. Lascaris se troubler; il se tourna vers moi, et me dit en italien, pour n'être pas compris des autres personnes, "Cosa dite di questa novità, che mi ha molto scoraggiato?"-" Je ne crois pas," lui répondis-je, "à toutes ces histoires; et, quand même elles seraient Traies, il faudrait encore persévérer dans notre projet."
\end{abstract}

Récit de Fatalla-Sayeghir, quoted by Lamabtine, Voyage en Orient.

The King of Oude and his "Desert-house"-We are sent away with gifts-The Mesopotamian desert-Pleasures of freedomHow to navigate the desert-Alarms and false alarms-Stalking a wolf-We reach the Shammar.

Kasueyn, February 24.-Bagdad is an abode of political exiles from India, Mussulmans who dislike living under Christian rule, and who have settled here as the nearest place of refuge in Islam. Their position is a pleasant one, for they enjoy the double advantage of religious agreement with the Bagdadis and of foreign protection as British subjects. Many of them are very well off, living on the revenues of their lands in India, and a few are on excellent terms with the Consul General. Of these the most remarkable, by his birth, his wealth, and still more by the dignity of his private 
character, is the Nawáb Ikbálet Dówlah, the dispossessed and pensioned king of Oude. With him we are now staying, at his " descrt-house" near Kasmeyn, the first step on our journey northwarcls. I hardly know how to speak of the Nawáb without seeming to say too much. He is an old man now and a philosopher, and he would not care to have his good dceds paraded, and yet I cannot help recording what I feel about him, that, little as he affects the character of ex-king, he is the most truly dignified personage I ever met. In manner and way of living he is rery simple, having something of the Beclouin contempt for appearances, along with the more real absence of pretension of a well-bred Englishman of fifty years ago. He has travelled much and seen much, and understands the European way of thinking as well as that of eastern people, having besides considerable originality of his own independent of any school of icleas. In conversation he is most agreeable, constantly surprising one with unexpected turns of thought and new ways of saying things, and, if we had been able to understand him better, I am sure we should have found him full of the best sort of wit. He is besides a kind and charitable man. His position in Bagdad is a great one, so great, from a moral point of view, that it may well console him for the loss of his former sovereignty and the splendours of his court at Lucknow. Here at bagdad he has real power, the power of doing 
214 Bedouin Tribes of the Euphrates. [сн. хII.

good, and real freedom to say what he thinks right to consuls, pashas, doctors of divinity and all alike, down to the poor Bedouins who live at his gates. I fancy his advice is asked on most of the political difficulties of the Serai, where his knowledge of men and cities, so essential a part of wisdom in the East, and his wit in expressing his ideas, enable him to speak without offence more truth than is often heard in those high places. The consequence of this is that his name is a power in Bagdad, and that he has made himself friends in all classes of society. Amongst the rest, Ferhán, the Shammar Chief, is his sworn ally; and, whenever the Sheykh comes to town, it is to the house of his brother the Malek el Hind, or King of India, as the Arabs call the Nawáb. This circumstance is most fortunate for our plans, as now we shall start for the desert with letters of recommendation, which ought to give us the best possible reception there.

The "desert-house," where we are enjoying so pleasant and so unceremonious a hospitality, is one of the many owned by the Nawáb in and about Bagdad. It stands quite alone, in the barren plain which surrounds the town, and is about half a mile distant from the mosque of Kasmeyn. The townspeople, who are very timorous about venturing outside the city at night, think the Nawáb foolhardy in the extreme to live in such a spot; but to him, as to us, the isolation of the house is its principal charm. He generally, however, lives in Bagdad, 
but comes here from time to time to make a retreat, partly philosophical, partly religious, among the ílemas and doctors of theology of Kasmeyn, for the mosque is a sanctuary and place of repute among pious shíahs.

The house itself is as original as its situation, and was built from the Nawáb's own designs. It is constructed like a fortress, with high walls and a single entrance, a very necessary precaution against common robbers as well as marauders from the desert. Above, on the upper story, the rooms are placed, some with the windows facing outwards, after the fashion of Turkish rather than of Arab buildings, others looking on to a terrace, over which there is yet a second story. The entrance is through a courtyard, with stables on either side and dovecotes inhabited by thousands of white pigeons. The ground-floor is merely a basement, and stone steps lead up from the court to the apartments. These consist mainly of small rooms, furnished with carpets only; but the drawingroom is large, and is so peculiar that I have made a plan of it. Its shape is that of a cross, each of the three shorter ends being occupied by a window, so that the upper half of the room is almost a lantern. The recesses are filled up with broad divans, on which it is pleasant to sit and look at the view. On one side is the Mosque of Kasmeyn, with its golden cupola and four minarets, embowered in palms; on the other the desert with its 
immense horizon, broken only by the far-away tower of Nemroud. The sun is setting nearly behind this, and all the desert is painted a beautiful pink colour, the dome of the mosque being quite ablaze. It is a most agreeable prospect, giving promise of fine weather for to-morrow's start.

We came to-day from Bagdad, riding quietly out at about two o'clock, and leaving the camels to follow us with Hánna and a cavass, lent us by Colonel Nixon, so as not to provoke any inquiries as to our journey. We have not said a word to any one of where we are going, beyond Kasmeyn, and are starting without even a buyuruldi, the customary permission of travelling in the province; but to-morrow we hope to be out of the reach of questions, and to-night the Nawáb's house is a sanctuary no zaptieh would dare invade.

Nine o'clock.--There are a few families of a very low tribe of Arabs, encamped quite close to the house, the Chakukh, a fraction of the Butta tribe, some of whom we have already made acquaintance with at Ctesiphon. They are living in temporary huts, built of tall reeds from the Khor or lake, which encloses this side of Bagdad, and roofed with the ordinary tenting, so that their abodes pretty closely indicate the life they lead, half settled, half nomadic. They have a few sheep and goats, which they pasture by the Khor. After dinner this erening, the Nawáb sent for some of these Arabs to sing and dance before us, a performance which I 
could willingly have dispensed with. The music consisted of a drum and a double pipe, eight inches long, and sounding in its best, the deepest, notes rather like a hautboy, the upper notes being out of tune and bad, while some double notes, fifths and sixths, were better. The voices were very bad indeed. As to the dancing the less said about it the better, and we were very glad when it was at an end and the Nawáb, who had sat through it all absolutely unmoving except when he fingered his rosary, bade them be off. The Arabs around Bagdad are probably as low and degraded a set as can be found anywhere in Arabia, having been col'upted by the neighbourhood of this old city of pleasure, or I am sure such an exhibition could not have been produced.

This over, the Nawáb made us an affecting speech of farewell, wrote with his own hand the letter he had promised us for Ferhán, and added a basket of oranges and pomegranates, to give him with it. Then he had another huge basket brought, containing provisions for ourselves, and a third which he filled himself with cakes, macaroons, preserves and fruit from the dinner-table, and an earthen bottle to hold water, and then, before I could take breath from surprise, a beautiful Persian rug "to put on my dromedary," and a little silver bowl to drink out of, whenever I should come to a fountain, pretty gifts in themselves and doubly so from the way in which they were given. It was impossible 
to refuse or be otherwise than delighted to accept them. Now for a last sleep under a roof, and tomorrow at daybreak for the desert.

Monday, February 25.-We got away from the Nawáb's house only a little after sunrise, and at first followed the caravan road which goes to Hitt, our host and Dr. Colville riding a mile or so with us on our way, and giving us a few last words of encouragement and advice. It was a delicious morning, clear and bright, and the soil of the desert sparkled under our feet as if it had been strewn with salt, while a light wind from the northwest blew freshly in our faces. We were in high spirits, as was natural, for what can be more physically delightful than a ride on such a morning, or what more inspiriting than the thought of being fairly away upon an adventurous journey!-and this time I think we may consider ours a serious one. To say nothing of the dangers, in which we only half believe, there are all sorts of uncertainties before us, from the fact that we are entering an unknown land. Mesopotamia, at least this part of it, has never, as far as I know, been crossed by a: European in its whole breadth, or in modern times even by a townsman from Bagdad or Aleppo; and the desert south of the Sinjár hills is quite new ground. It is there that we shall have to go, if we want to find Faris and the independent Shammar,and who knows what adventures may befall us on the road? At any rate, we shall be left entirely to 
our own resources now till we get to Deyr, a journey of nearly 400 miles, for we shall not meet with a village or even a house in the whole distance, except perhaps Tekrit, on the fourth or fifth day from this. Colonel Chesney's survey is our only guide; and, but for a ruin or two marked near the river, and such remarks as "horsemen seen on this hill," "large herds of gazelles," or "a newly-made grave," on Lieutenant Fitzjames's route in 1836, and on that of the Expedition returning in 1837, the whole of the map north of Bagdad is a blank space. Our plan of campaign is this: we are to take a straight line north-north-west, for fifty or sixty miles, till we hit a bend of the Tigris; then follow the right bank of the river for ninety or a hundred more, as far as Sherghát, the head-quarters of Ferhán, the Shammar chief. There we are to deliver the Nawáb's letter, and get him to send us on to Faris, wherever Faris may be. From Sherghát to Deyr it is about a hundred and sixty-five miles as the crow flies, but if, as is probable, we have to go as far north as the Sinjár hills, our journey will be considerably longer. The chief difficulty seems to me to be in getting from Ferhán to Faris, for, in spite of what they say at Bagdad, it is impossible the two brothers can be on very good terms. However, the thing must be done by hook or by crook, and we must be at Deyr to meet Mr. S. on the 15th of March, for this is a positive engagement. 
As to the danger of meeting ghazús, the only real risk we run, Wilfrid and I have had a serious conversation, for it is well to be prepared with a plan before the thing happens. We ourselves are so well armed that, though the rest of the party cannot be expected to help us much, we ought not to be afraid of less than fifteen or twenty men. The Bedouins are only armed with the lance, and their pistols, by all accounts, never go off, so that Wilfrid's double-barrelled gun and the Winchester rifle, which fires fourteen shots without reloading, ought to make us far stronger than any small party of Arabs. We are, therefore, to hold our ground and trust to their being too prudent to push us to extremities. If, however, we meet a large party, such as, it seems, sometimes goes about, of fifty or a hundred horsemen, it will be no use fighting; and then, if they refuse to listen to terms of capitulation, we shall have to abandon the camels and baggage to their fate, and trust to our mares to carry us out of the difficulty. We are well mounted, and ought not to be overtaken easily. At the worst, according to every account, there is no fear of being personally ill-treated, for the Arabs only care about plunder, and the utmost misfortune that could happen to us, if captured, would be to be stripped of some of our clothes, and left to find our way on foot to the nearest inhabited place; not a cheerful prospect certainly, but still not altogether desperate. 
I do not think, though sometimes I feel nervous about it, that we really run much risk of meeting anybody evilly inclined. In the first place we have the Nawáb's letter, which, though they could not read it, the Shammar would probably respect, and in the next we know how Jedáan and the Ánazeh are engaged at present, and how little time they can have to spare for expeditions of this sort in eastern Mesopotamia. Hanna and the rest of the people with us are, of course, timorous, and talk incessantly of these ghazús, but fortunately they have no property of their own with them, except the clothes they stand up in, and they know that if they lost these we should give them new ones instead. Hánna, I am bound to say, puts an excellent face on the matter, and has full faith in the Beg and in Divine Providence. Ali, the carass, is a fat Bagdadi, who has to be helped up on to his horse, and does not impress us favourably as a practical traveller, but he seems good-humoured and willing to do his duty. The other two members of our party, the Agheyl, are honest, hard-plodding fellows, who work cheerfully and take great care of the camels, but we can hardly judge correctly about any one of them as yet. The camels are capital walkers, doing their three miles in the hour, a rery unusual pace, and Wilfrid is especially pleased with his delúl. He mounted it to-day for the first time, and intends to keep Hagar as fresh as may be for the accidents of sport or war. 
A couple of hours after leaving Kasmeyn, we stopped at an inlet of the Khor, to let our beasts drink, and to fill the water skins. Then, leaving the caravan road which here takes a turn westwards, we struck out across the plain, going in a straight line north-north-west, with only the sun to give us our direction. In this way we travelled on all the morning, watching our horses' shadows as they crept round from the near to the off side, and not stopping even for a minute. We were still on the alluvial soil of Babylonia, which at this time of year is more bare than the desert itself, the only vegetation being a dry prickly shrub called aghuil, which the camels snatched at greedily as they went along. The ground was full of deep cracks, which made it rather dangerous going for horses, and, relying on this perhaps, gazelles are to be found here very plentifully. We saw a good many during the morning, but did not give chase. Every two or three miles we came to long double lines of mounds, the remains of former canals. These have all the appearanee of natural hills, and rise to a height of twenty or thirty feet above the level of the plain. We put up numerous flocks of larks, and Wilfrid shot a Norfolk plover, but otherwise there was not much life on the plain. Once or twice we came across small parties of Simmím Arabs, with donkeys, bringing in firewood. This they told us was shôk; the word merely means "thorn," I believe it was camel-thorm. It grows in large 
bushes and burns, like all desert shrubs, as well green as dry.

About midday we came to gravelly soil and more undulating ground, the edge of the real desert. The camels were very hungry, not having had a proper meal yesterday, for they will not eat corn, and the country round the Nawáb's house is as bare of all pasture as a turnpike road. We accordingly ordered a slower pace and allowed them to feed as they went, and at three o'clock, coming to a place where there is some grass and a pool of rain water, we have stopped. There are some tents about a mile from us belonging to the Meshaabe, a halfpastoral, half-felláh tribe, harmless good people who have brought us milk, not as a matter of hospitality, but "minshan flús" (for money). We have only come about sixteen miles to-day, but I am tired, I suppose from the change of life to our travelling rations, after the four full daily meals of the Residency. Wilfrid is perfectly happy, being once more "in his own tent," and having, besides, his own camels now and his own servants, and no guards or policemen to rex him. Those, who have lived all their lives in Europe, don't know what a luxury it is to feel oneself "free from the police."

Febuary 26.-Wilfrid has had to speak scriously to Ali, who seems inclined to require more waiting upon than we can spare him. He is very fat, and really has some difficulty in climbing into his saddle, but it is necessary he should understand that the 


\section{Bedouin Tribes of the Euphrates. [сн. хи.}

Agheyl cannot be called away, from their business of driving the camels, every time he wants to get off or on his horse, nor made to tap the water-skin for him every time he feels thirsty. The fact is, every one of us has quite enough work to do, and we cannot afford to have idle hands in the caravan. This little matter settled, all has gone on well, and we have made a good march to-day of twenty-seven miles, according to Wilfrid's dead reckoning. At starting, we passed through the Meshaabe camp, and stopped at the principal tent, to ask a few questions and drink some fresh goat's milk. A building three or four miles off to the east they say is the Khán Suadiyeh, on the old caravan road to Tekrit. The Meshaabe, like all the other small tribes, have no camels, only sheep and goats, and some of them cultivate land near the Tigris. They are reckoned at a thousand tents, according to our Agheyl Nejrán, who puts the Bútta at half that number.

We kept the same course to-day as yesterday, north-north-west, crossing tracts of fine gravel in some places, and in others of alluvial soil, with numerous Babylonian mounds and canals. The whole district is in fact cut into regular squares by them, so that one travels with the feeling of being in an enclosed country. It is all desolate enough now, inhabited only by gazelles, of which we saw great numbers, and by birds of prey. We passed close to a pair of fine golden eagles sitting on one of the mounds. In one place, where there was a little 
pasture and shôk bushes, we found a pit dug as a hiding-place for gazelle hunters, but except this there was no trace of inhabitants.

We had seen nobody all the morning, when about noon we suddenly became aware of some horscmen, bearing down upon us. We could see the points of their spears glittcring in the sun, and as they were evidently coming up at a gallop, Wilfrid ordered a halt. There were four of them, and when they came within half a mile of as they stopped and dismounted, waiting, I suppose, for others to come up. Two or three more straggled in, and then they cantered up together towards us. Wilfrid, who had becn riding the delúl, now mounted his mare, and went to meet them with Ali and Nejrán, while I stayed with the camels. I soon saw that it was all right, for the men dismounted, and the whole party came on together talking and laughing. It was a false alarm. They were not Bedouins at all, but a party of Government people, who had been out collecting taxes from the shepherds of the district, levying, they told us, half a beshlík, fivepence, on each sheep or goat. They had with them a man on a mule, who was making his way to Samára, a village beyond the Tigris, and who, hearing we were going more or less in that direction, tacked himself on to our party when the rest went away, as they presently did, after the usual amount of talking. Talking is a pleasure no Arab, whether from town or country, ever neglects an 
occasion to indulge in. We did not want the man's company, but there was no getting rid of him, as it seems to be a sacred privilege in the East to join company with anybody you may meet on the road. "The more the merrier" is a proverb all accept. So he followed us.

A little further on, on some higher ground, we came to several people wandering about on foot, apparently with no object but that of examining the ground and stopping now and then, as if to pick up a stone. We found on inquiry that they were hunting for the white truffles, kemeyeh, which I have already mentioned, and which are very common here. These people belonged to Suméycheh, a small village, the palmtrees of which they pointed out to us far away on the horizon to our right. It stands on a sort of side channel of the Tigris. The Agheyl were anxious to go towards these trees, though out of our course, for they do not at all approve of our way of going in a straight line and keeping in the open desert, and they have all along shown an inclination, if I may use a sea phrase, to "hug the shore."

Wilfrid when he is on his delúl is obliged to keep with the camels, and then I have to ride in front and give the direction. This requires a good deal of attention in a country where there are so few landmarks, but it is not really difficult as long as there is sun or wind to go by. The shadow of one's horse's neck makes an excellent dial, and, with a 
little practice, it is easy to calculate the rate at which it ought to move round, so that the course should be a straight one. The wind, too, in this country almost always blows north-west, and does not shift about in the plain, as it would among hills. Wilfrid has made so many journeys now without guides that he at least feels quite at home in the desert, and I, though my experience is more limited than his, have seen enough to know that one is far less likely to lose one's way there than elsewhere. The weald of Sussex is ten times more puzzling to get across.

Early in the afternoon, we came to an immense double row of mounds, running in an absolutely straight line north-north-west. This is by far the largest Babylonian canal we have yet seen, and we are surprised to find no mention of it on our map, as it is a considerable feature in the landscape, and no doubt comes from the Tigris. The Agheyl and the man on the mule call it Cherrisáda. There are groups of mounds here and there in its neighbourhood, showing where villages once stood, and in one place we came upon a perfect square which may have been a fortress. In deference to the entreaties of the Agheyl, backed up as they were by the man on the mule, we altered our course a little and followed the line of the canal. This led us to lower ground, on the edge of which we have encamped, not more than a mile from a kubbr or tomb, which Ferhán recognises as a landmark he 
has seen before and calls Abu el Mehásin. About two miles off to the east, we can see some tents, and Ali has been dispatched with the delúl to see if water can be got, or milk or eggs. The man on the mule, who, by the way, was kicked off and hurt this afternoon, says that Jisr Harba is only three miles from the canal; this fixes our position, as "Harber bridge" is marked on Chesney's map.

This is ideal camping ground, a beautiful hollow, full of good grass and. shôk bushes, where the mares are feeding, while the camels find pasturage they like better on the upper ground. Our tents are pitched on gravel, and we have no neighbours to bore us. One of the charms of tent life is the feeling of absolute ownership one has in each spot of ground one camps on-the right to do precisely all one likes with it, to cut down, dig up, or leave alone, without permission of any landlord or liability to land-tax, tithe, rating, or other burden, such as limits every form of ownership in England. Here it is absolute and complete, even to the closing up of rights of way, for one is at liberty to treat all comers, if one likes, as enemies, and to bid them be off. Not that at present we have hostile feelings towards anyone. Only it is nice to think that even the keeping of the peace depends on our good will and pleasure, not on the law of the land. Liberty, in spite of the crimes of nonsensical talk which have been committed in its name, is the greatest 
of all blessings, and in its perfect form is not to be found in Europe.

Ali has come back with water and other good things, and has brought a couple of Arabs with him (Kasaréj, they call themselves), who confirm the man on the mule about the position of Jisr Hárba. They talk of their tribe having twenty thousand tents; but that of course is nonsense. Nejrán says, however, that they are more numerous than the Butta or Mesháabe. All these tribes are alike, half shepherds, half ploughmen. The Kasaréj have some fields below us, irrigated from the "little Tigris," and I can hear a faint quacking of ducks, which proves that water is not far off. A square tell (mound) about two miles west of us is Abu Raséyn.

February 27.-Another good day's march has brought us to the Tigris. We lost time, however, by listening to the man on the mule yesterday, for in order to cross a branch of the Cherrisáda canal called Ferhatýeh, about which there would have been no sort of difficulty where we first came upon it, we had this morning to go a considerable way round. The Kasaréj still make use of this canal for some miles of its course, and the ditch (it was no more) was just too wide for the camels, though of course our mares hopped over it without difficulty. After that, the piloting of the caravan was very troublesome and reminded Wilfrid, he said, of riding a horse which bores towards one side. Every moment 


\section{Bedouin Tribes of the Euphrates. [сн. хII.}

that our attention was taken off their movements, we found that the camels had been headed away to the right, and we had to go back and insist on their following us. The Agheyl and the man on the mule could not understand how we should know anything about the direction, and maintained that we were going away from the river "into the Jezíreh, into the Chôl," they said, and put an accent of terror into the words. It was, therefore, no little triumph when, about one o'clock, a speck appeared on the horizon exactly in front of us, which the man on the mule admitted was the tower of Samára. It seemed at first but a very few miles off, but turned out to be at least fifteen or sixteen, as it stands on high ground and is a very lofty building. It is on the other side of the Tigris. Presently afterwards, we passed some tents, where there were a mare and foal, and riding up to them, we found their owners were Delím. We were surprised to find any of this tribe so far from their head-quarters, the Euphrates, but they told us they came across the Jezíreh every year. With this exception, we met nobody all day, but saw numbers of gazelles and bustards, also two foxes almost white. Most of our journey was over the gravelly desert. About midday, we crossed another long: line of mounds, where we stopped to let the camels feed, as there was éshubb (camomile), which the Agheyl declare is "as barley" to camels.

As we came nearer the tower of Samára, we saw 
several other large buildings, apparently ruins, at different points to the right of it. In fact the left bank of the Tigris, opposite where we now are, seems to be an immense cemetery of cities, extending for many miles. These would be most interesting to visit, but we cannot get the camels across the river, and we dare not leave them unprotected. We console ourselves with the conviction that these sites have all, no doubt, been thoroughly explored. The names given them by the Arabs here are Jadsíeh, Gáyim, Melwích, el Ashid, none of them inhabited, mere "bcyút kadím," they say contemptuously, "ruins." Only one old town is found on the right bank of the river, Istabilat, which Wilfrid thinks must be Greek. We rode through it, as it lay in our way, and a very interesting place we thought it. It is laid out in squares, with a fine street fifty yards broad down the middle, and the houses, though all of them in ruins, are still standing. They are built of good brick, as is the city wall in a fairly perfect state, flanked with round towers. In the evening light the place looked almost as if still inhabited, and it is much more attractive than the tiresome Babylonian mounds. A canal passes right through the town, and the buttresses of a bridge over it can still be seen. It is dry now and half filled up.

A broad caravan road, apparently long disused, led from the gate of the town to the northwest. Following this we came rather suddenly on 
the Tigris, which here makes a fine sweep close under a steep cliff. We were some time looking for a way down this, as we thought it would be pleasant to camp near the river, but at last we found a very nice place, about half way from the top, for the tents, and a passage for the unladen camels down to the tamarisk beds below. The Tigris is here an exact reproduction of the Euphrates, only that its valley is not on so imposing a scale. The volume of the two rivers I should say was about equal, but the Tigris strikes me as being the more rapid. It is called in Arabic Dijleh, the Euphrates Fratt.

The Arabs here belong to the Jemáa tribe. They have a story of about twenty of their sheep having been driven off three days ago by some men from the Delím, the same I suppose as those we passed this morning. They talk a good deal about ghazús from the Anazeh, and I suppose it is for this reason that they are encamped in the tamarisk woods. There are francolins again here and pigeons and wild boars and jackals, so that, if one were to turn oneself three times round, as children say at blind man's buff, one might fancy oneself on the Euphrates. The place at which we have encamped is called Sheriét el Ghazál.

February 28.-We were disturbed about midnight by a cry of thieves. Our own mares, who sleep with their noses in our tent, were safe enough, and the camels were squatting composedly 
in a circle outside them, but Ali's hor'se was gone. This horse, I must say, has been the greatest possible nuisance to us from the day we left Bagdad, fidgetting and neighing and breaking loose night after night, so that our sympathy with his disappearance was not altogether unmixed, but there was not long cause for sorrow. Our position, on the ledge of the cliff, was one not over favourable for a thief to get away from with his prize in the dark, and after stumbling about and creeping with our heads near the ground to get a sight of him against the sky, we found the horse at the edge, over which the thief, disturbed by our alarm, had no doubt just slipped. It was not far to fall, and we heard him scuttling away through the tamarisks below. This put all the camp on the alert, and most of the night was spent in talking and singing to show we were awake, Ferhán keeping it up long after the rest had dozed off again, by whistling a long plaintive note like a marmot's.

The sun rose red and threatening from behind a thick bank of clouds, and just as the camels werc loaded a gust of wind from the south-cast struck them, which nearly tumbled them over the cliff and sent the lighter luggage flying. The air becane full of sand, and a few drops of rain fell, but nothing came of it. Only the wind continued. Our route to-day was across part of the 'Tigris valley, where there was cultivation in patches. We marched slowly, letting the camels feed as they 
went, and making the castle of el Ashid our point, for we find that this is after all on the right bank of the river. Samára, on the opposite bank, about two miles from us, looked an interesting place with a fine mosque, gilt like the mosque of Kasmeyn, and two minarets (they say it is a "holy place"), while the tower which we had seen so long yesterday, is really grand. Its height must be very great and its construction is most peculiar, reminding one only of pictures of the tower of Babel, which very likely it originally suggested. It is round and tapers gradually almost to a point, having a spiral staircase outside. It stands in an enclosure, with very high walls which must be nearly half a mile square. If we had not been afraid of getting into some difficulty with the authorities residing there, we should have tried to pay it a visit, as there must be a ferry, though we did not see one, our man on the mule having left us to go across.

Except this view of Samára, and a singular rock of conglomerate jutting out into the valley like a bit of masonry, we passed nothing of interest till we came to el Ashid, or as it is marked on the map Kasr Bint el Khalifeh, the Castle of the Caliph's daughter. This is a most picturesque and interesting ruin. It stands on a promontory of the cliff and overlooks an immense length of river up and down. It is square and, as we found, still sufficiently well preserved to make us rather doubtful how to ride our horses in over the crumbled walls. 
But a breach had been made on one side, and there we got in. It was a more difficult matter to stay, however, when we got there, for in such an exposed place the wind nearly blew us away. The castle is built of burnt brick, and there are remains of rather elaborate architectural mouldings in this material. It is undoubtedly Saracenic. Wilfrid, while I tried to make a sketch, managed to get a brace of partridges and a pigeon, very much wanted for the pot.

Rain was now falling heavily, the first we have had since we left Bagdad, for the weather has hitherto been quite hot, and we agreed to stop as soon as we could find a sheltered place, although we had only marched some twelve miles. There is capital grass everywhere. We are accordingly encamped in a little side valley, where there is a convenient screen from the wind in the shape of a low cliff, and we have changed our wet clothes and a fire is lit, and dinner getting ready. It threatens to be a wild night, but we hope the rain will kecp robbers away. We have arranged a cord round the exposed side of the camp, to trip up intruders.

March 1.-In the night the wind changed suddenly round to the north-west again and nearly blew the tents down, bringing March in indeed like a lion. It is bitterly cold, but the rain has ceased. Wilfrid took some observations from the cliff, and finds that El Ashid, Samára, and the kubbr, Imám Dúr, which is opposite us, are all marked wrong on the map. Indeed, it is difficult 
to make out at all what Colonel Chesney can have been thinking about here, for on the Euphrates he was very accurate.

While we drank our coffee before starting, we saw a wolf come over the brow of the hill behind us and sit down very composedly to watch us. Wilfrid determined on a stalk, and did so most successfully, getting within twenty yards of him and shooting him through the heart. Only (I grieve to say it) the wolf turned out to be a jackal. In the morning light he had looked unnaturally large, and we had not been able to see his tail, which is the only difference in shape between the jackal and the wolf.

We have been much discomposed to-day by a report we have heard repeated several times by Arabs we have met, of a ghazú of seventy horsemen, said to be Ánazeh, which passed along here yesterday. Very likely it is exaggerated; but there must be some foundation for it, as the people who told us were evidently alarmed, and it has made us very cautious in keeping a good look-out. Wilfrid and I ride on about a mile in front as advanced guard, while Ali, who has better eyes than most of the people here, guards the rear. It is curious how much nonsense is believed in Europe about Arab eyesight, the fact being that it is not particularly good. We always see things long before the others do. To-day, for instance, we caught sight of a wavering bit of light and shade, much distorted by mirage, which we could see very 
well was a distant range of hills, but which the Agheyl declared were clouds. They are no doubt the Hamrín hills, marked on the map as about fifty miles from where we first saw them, and interesting as becoming further eastward the boundary between Turkey and Persia. We made them out quite distinctly by riding to the top of a tell.

We passed to-day through a camp of Suámra Arabs, and at a little distance further on we put up an immense wild boar out of a patch of tamarisk and argál. He trotted past quite close to me. Wilfrid shot some francolins and partridges and a hare, the first we have got on the whole of our journey. Hánna's delight may be imagined. "We shall eat tonight," he said, "what would cost half a mejidié at Aleppo," —and half a mejidié to Hánna's economical mind is an enormous sum. The reports about the ghazú have becn conflicting, one man telling us it had gone on to Tekrit, another that it had passed over the hills westwards, while half a dozen villagers from Tekrít itsclf, which is not far off, say that they have met nothing on the road, and believe it was not a ghazú, but a band of robbers. These would perhaps be more disagreeable still to meet, but, please God, we may yet escape. Wilfrid has gone shooting in a wood of argál, a thorny bush with green fleshy leaves, which here takes the place of tamarisk. We are cncamped under a very fine cliff, with plenty of natural barley and rye for the mares and camcls, 


\section{Bedouin Tribes of the Euphrates. [сн. хи.}

and on this account have stopped early, after only sixteen or seventeen miles' march. Wilfrid's bag to-day is:-four francolins, five desert partridges, one large red-legged partridge, two teal, one hare, one jackal.

March 2.-We left the valley, and, climbing by a rather steep track up the cliff, found ourselves at once, as it were, in another world, the world of the desert. This change was of course nothing new, but it affects me as strange every time it occurs, - the difference which these few feet make being so absolute. It was not long before we caught sight of Tekrit, a miserable looking hamlet something in the style of Deyr, but without even a minaret, and we made a detour to avoid it, as we are not in want of provisions and wish to see nothing of mudírs, kaimakáms, and zaptiehs. We then crossed a road leading, Ferhán informed us, to Ána, but not used now, as there is "khóf" (fear or danger). A little further on Nejrán, who happened to be some way in front, turned round and called out that there were Bedouins coming. The ground was undulating, and they were already close to us before we saw them; but there was nothing to fear. There were nine of them, mounted on delúls, but unarmed, and they informed us they were going to Tekrít on business from Ferhán ; still they were the first Shammar we had seen, and we looked at them with interest, almost with awe. They had a rollicking, devil-may-care way of looking and 
talking, rery different from the manner of the fellahín Arabs we have hitherto had to do with, marking them as men of an almost different race. They asked us a question or two in return for ours, and went on their way without any ceremony.

At two o'clock we came again to the valley, where we found a beautiful green plain, covered with buffaloes and other cattle, and a large camp, the men of which told us they were Ajuári. Across this plain we travelled for a couple of hours, and have now stopped in much such a situation as last night's camp, under a cliff and surrounded with the greenest grass. Our mares have fattened rapidly on the journey, as we have hitherto had corn to give them, as well as what they pick up, and that is not a little. There are still great herds of buffaloes near us, being driven home for the night to a camp not a mile away. The people (Jibúri) from it have come to us, and seem one of the best tribes we have yet met, good-natured, honest folks, as, we have remarked, all owners of buffaloes are, ready to fetch milk, butter, or anything else we want, but sufficiently commercial to expect payment for what they bring. They seem prosperous, peaceable and happy,-felláhin, but of the best sort. They tell us they are tributary to the Shammar, that they are not a fighting tribe, and that the Ánazeh, when they come, as they do most years, to make their raids upon the Shammar, do not meddle with their buffaloes. 'The first Shammar' 
camp, it appears, is only three hours' march from here,-not Ferhán's, however, he is further on at Sherghát, but Ferhán's people's, under a sheykh of the curious name of Múttony, pronounced as written. So for good or for evil we shall see a real Bedouin camp to-morrow : let us hope for good.

We have marched twenty-six miles to-day from point to point on Chesney's map, our position at present being about three miles north-north-west of Abu Reysh, a ruin which we can see very well, and we have done it in eight hours, pretty good going for loaded camels or for any animals, for the matter of that. It is forty-eight miles on now to Sherghat, so that we may hope to get there the day after to-morrow. A traveller on foot has come to our camp with two little bags slung over a stick on his shoulder. He is a pedlar, selling tobacco to the Arabs. He has a rough pair of wooden scales, and a pebble which he uses as a weight. A funny old man, good-humoured, and asking for nothing. There are some other guests, too, in the shape of some little dish-washers, which are tame enough to come almost inside the tent.

Sunday, March 3.-We were in no hurry to start this morning, having only three hour's' march before us, and I had time to take a sketch from the top of a high mound, while Wilfrid made a discovery of refuse glass, showing that at some period of history there must have been a glass foundry here. The cliffs are of sandstone, and fifty to a hundred 
feet high. The view of Jebel Hamrín was very beautiful, its ravines and indentations furrowing its slopes with a network of blue shadows. We could see the cleft through which the Tigris issues, on its passage from the upper plain of Assyria into the 3ower one of Babylonia. Formerly the Hamrin hills must have been the boundary of the two kingdoms.

My mare, Tamarisk, has hurt her foot, and is so lame that I have been riding the delúl, a most comfortable way of travelling; but it is tiresome to have to keep with the camels, instead of riding to see what is happening. Besides, the motion is so smooth that I get very sleepy. Wilfrid in the meantime was enjoying himself galloping after jackals and foxes, one of which he wounded, but it got away among the rocks of the cliff, and I felt very envious, and tired of seeing Hagar careering away on the horizon, "scarce so gross as a beetle."

After passing some large Jibúri camps, where they gave us milk and lebben, we came to a ruined khan of the Saracenic age, marked on the map as Kerninah, a beautiful building with horseshoe gates. At another Jibúri camp further on, we learned that Múttony and his Shammar were encamped under the hills five or six miles off to the cast of north, while our course, if we wanted to go to Sherghát, should be north-west, for camels camnot get across the range of hills here, and have to go round to a place where there is a pass leading to the Wady

VOI. I. 
Gehennem. This encouraged Nejrán to attempt inducing us to shirk the Shammar altogether, for like all townspeople, he has a wholesome horror of Bedouins, and he proposed that we should make instead for a camp of Zoba, said to be nearer to our line of march. None of our party know as yet where we are bound for after Sherghát, and the Agheyl are under the impression that we are going on to Mósul. Hánna knows in a vague way, that we expect to meet Mr. S. at Deyr, but his ideas of geography do not go far.

It is needless to say that we paid no sort of attention to Nejrán's suggestion, and that Wilfrid struck off in the direction pointed out by the Jibuiri. Ali now for the first time came to the front, and though apparently rather nervous, stuck close to Wilfrid as he galloped on to reconnoitre. Nothing, however, was visible but the desert and the hills for the best part of two hours, until at last a man was sighted peeping over the crest of a tell, and Wilfrid rode up to question him. "Who are you ?" "An Arab." "Where from?" "From the Arabs out there," pointing in the direction we had come from. "Shammar?" "No." "Jibúri??" "No." "Zoba?" "No." "Then whose are those camels?" "The Shammars'." "Where are the Shammar?" "Out there, far away, far away," pointing to the hill. "Come and show us, there's a good man. We are friends of Ferhán's on our way to Sherghát, and we want to speak to 
Múttony." "Very well. I am one of Múttony's men." "And a Shammar?" "Yes." "Mashalláh! come along."

This matter settled, it presently appeared that the Shammar camp was close by, hidden by some rising ground, to the top of which our new acquaintance took us, informing us the while that Múttony himself was not there, being away on a ghazú against the Ánazeh, but that we should find Hatmoud ibn Hîyet at home and very pleased to see us. These Shammar are of the Áslan tribe. We soon saw below us a scattered camp of about twenty-five tents, a great number of camels and a few mares, perhaps half a dozen. I got on my mare so as to arrive with becoming dignity, and Wilfrid gave his gun to Hánna and put on a sword which he has been keeping for state occasions. Mr. S. had told us what to do, and how to behave among the Bedouins, but we both, I think, felt rather shy at this our first visit, arriving as strangers and unannounced. Nobody came to meet us or seemed to pay the least attention to our party, and we rode on without looking to the right or to the left towards the largest tent we could see. There we dismounted slowly and walked into the tent.

The etiquette of an Arab reception is a rather chilling thing, when experienced for the first time, and we have never before been en cérémonic among: the Bedouins, for in the French Sahara, and the Egyptian desert, European travellers are well 


\section{Bedouin Tribes of the Euphrates. [сн. xir.}

known, and are treated after European fashion. Here we are probably the first Europeans ever seen. Nobody moved till we had come inside the tent, and Wilfrid had said in a loud voice "Saláam aleykoum," to which everybody, for there were perhaps a dozen men sitting there, answered also in a loud voice "Aleykoum saláam." Then they rose to their feet and politely made way for us to enter, the principal man bustling about to have a carpet spread and a camel saddle brought for us to lean our elbows on, for such is the custom. We sat down without ceremony, merely making the usual salute of raising the hand to the mouth and head and looking solemn and unconcerned, for so Mr. S. had recommended us to do; but the ice once broken, Hatmoud and his friends seemed willing enough to talk, and anxious to do everything they could to make us comfortable. Ali has come out in quite a new light, for he is very useful in keeping up conversation for us, always our difficulty, and very clever in making any little private arrangements as to the pitching of our tents, and the getting of corn for our mares, and other things which one wants done but does not like asking for. Of course, there is no question of paying for anything here. In this he has shown considerable tact.

Hatmoud's tent is a very poor one, and we are disappointed in finding no external signs of greatness among these Shammar, more than in the tents of their lower brethren Jíburi Delím or Aghedáat. 
Except one carpet and the saddle, there is absolutely no furniture, and the coffec is made in pots no better than Sotamm's among the Jerîfa. The men, however, are better behaved than most of those in whose tents we have been, and have asked no impertinent questions. In a few minutes, thirty or more of them had collected round Hatmoud's fire. They made no secret of their Sheykh's proceedings. Múttony was away towards Ána on a ghazú, with a thousand horsemen from the Aslan, besides what he had mustered from other Shammar tribes, for it would seem he is Akid or military leader of the clan.* This expedition may account for the absence of mares in the camp, or of armed men, for very few of the tents were distinguished by the aristocratic spear. Múttony was to cross the Euphrates somewhere near Rowa, and was to attack the Mehéd, Jedáan's people. The name of the Aslan camp is Howshweysh, a difficult name to pronounce and impossible to write. When we had conversed for half an hour, we retired to our own tent, pitched just behind Hatmoud's, and by Ali's arrangements had our dinner served there, which is a far better plan than eating with the Arabs, and which they made no objection to our proposing. There are a great many dogs about the camp, and a few greyhounds called by the Arabs tazch. Thus ends our first evening among the terrible Shammar, of whom we have heard so many tales,

* All this account was an exaggeration, as we heard later. 


\section{Bedouin Tribes of the Euphrates. [сн. хіг.}

and who have figured as enemies in so many of Mr. S.'s adventures.

March 4.-With regard to our plans, of which it has been necessary that we should say something in answer to the inquiries of our host and others, Wilfrid has thought it best to conceal the exact truth-at least, as far as Faris is concerned-until we have found out what his real position is, with respect to Ferhán and the southern Shammar. We have accordingly talked a great deal to-day about visiting ruins and mounds, which they seem to understand well enough as an object of interest to Europeans. In this way we have hit upon a piece of information which may prove useful to us. We were asking about the "remains" at Sherghát, of which we had been told at Bagdad, as especially interesting, when the man to whom we were talking said, "Oh, that is nothing. If you want to see ruins, you should go to El Haddr, where there are stone pictures (súra hájar) and old houses more than you can count." We asked where this was, and he pointed north-west; which is exactly the direction we shall probably have to take; and Wilfrid asked him if there were any Arabs on the way. "Oh yes," he said, "you will find Smeyr, who is encamped just by the ruins." This made us open our ears, for Smeyr is a name which excites our curiosity on account of his late journey to Jebel Shammar; and we have determined, if possible, to sce him-that is to say, if he is not too far out of 
our road-and get all the information we can from him on so interesting a subject.

Hatmoud proposed in the morning, the very thing we wanted of him, to go with us to Sherghát. It will be a sort of introduction for us to Ferhán, besicles giving us protection on the way in case of an encounter with khayál (horsemen); so we readily agreed, and at eight o'clock we started. It was a white frost, and our tents were covered with rime, which, in spite of a bright sun all day, is still unmelted. At starting, our feet were so cold that we walked for the first mile or two, much to Hatmoud's amiable vexation, for he kept on telling us to "erkob, erkob" ("mount, mount") in a tone of command, as if it were his own mare he was offering us. But it is a way everybody has in this country, where the rule of minding one's own business is not accepted. This, however, is a small matter to complain of. In everything he seems most amiably disposed and anxious to oblige. He and his companion were fairly mounted, he on a bay mare he calls a Seglawíyeh and the other on a two-year-old colt, a Jilfán. They both of them admired Hagar, and when they heard her breed, Kehîlet Ajúz, put their hands to their heads in token of respect. 'They hurried us along, begging us not to let the camels graze, as there might be khayál about,-and they kept a good look-out towards the plain. On our right lay the Makhúl hills, a continuation of Jebel Hamrín, bare 
and red and intersected with ravines, which every now and then extended into the plain, cutting deep water-courses, and putting the camels to some trouble in crossing them. I again rode the delúl most of the day, for Tamarisk limps vexatiously. Hatmoud recommends a wet bandage in the evening of salt and lebben.

A couple of camels appeared in sight, and the follower was sent to reconnoitre, returning presently with two more Aslán, who came on with us. One of these, an old man, saw me eating an apple (one of the Nawáb's) and asked what it was. I gave him a piece, which he ate, and remarked, "Hôsh hada, basal" ("This is capital, an onion"). A little later, a large party appeared on the horizon, which we could not at first make out on account of the mirage. They seemed to be keeping a nearly parallel line with ours, and at first there was a suspicion of khayál, and the usual word "khóf" ("danger") was banclied about freely; but as our lines gradually converged, the cause of alarm proved to be nothing worse than some poor people with donkeys, travelling from Bagdad to Mósul. They had been seven days on the road and had come this way instead of taking the Derb es Sultan or highway round by the Persian frontier, because it is shorter, and they have nothing to lose. They were glad, however, of so good an escort as ours, and proposed to travel with us as far as we should go.

There was a woman in the party, and as we were 
both walking she came to me, and we had a little talk. She told me how tired she was, how she, and her husband Abdallah, and a boy of twelve, and a child of three had but one very small donkey amongst them. I saw Abdallah on it, with the child in front of him. The elder boy was walking, and she begged me to let him ride one of our camels, and seemed very grateful when I consented. She, poor thing, seemed to find life a burden; her feet were hurt by the stones, and she expected to be confined in about two months. The donkey shook her too much, she said, and so she had walked all the way. The thought of going home to Mósul was her only comfort-Mósul, such a beautiful town, her own bélled, far better than that wretched Bagdad, Abdallah's birthplace. The anticipation of home buoyed her up with hope. Two others of the party were Fatma's brothers, with a second donkey between them. One of the Aslán very good-naturedly dismounted to give the brother who was on foot a ride.

So the day passed, a long weary march, perfectly straight, but across a singularly pretty bit of desert, which nobody but I, I am sure, thought so. Wilfrid had ridden on with Hatmoud, and about four o'clock I saw them gallop towards some tents, which appeared still a long way off under the hills. When we came up, the two Shammar had stuck their spears into the ground in a nice wady, where there was grass, a mile or so from the tents. 
250 Bedouin Tribes of the Euphrates. [он. хіг.

This was the sign of our camp being chosen, so here we are pleasantly lodged enough and alone, for the Mósul people have gone on to the Arab camp.

... I am afraid we have made a stupid mistake; and it only shows how careful one has to be, in dealing with Arabs, not to hurt their feelings. We were resting in our tent, rather tired, writing our journals, when Hánna came to say that a lamb had been sent from the neighbouring camp. We had understood from Hatmoud, that the people there were not Shammar, but Haddadín, whom we had heard of as a very respectable, but commercial tribe, which makes its living by taking in sheep to graze from the townsmen of Aleppo and Mósul. We did not then suppose that the lamb came as a present, and having our larder full sent it away. But now several of the Haddadín have come, and with them their Sheykh, the sender of the lamb, who is much distressed at having his hospitality slighted. The Sheykh, a venerable old man with a singularly dignified countenance, was standing unnoticed by us in front of our tent, when Hánna returned with this explanation, and we have had much ado to make him forget our rudeness. We made him sit down by us, showed him our maps and asked him about his tribe. Still he remained grave, as Arabs do when they are offended, and then after a certain amount of talk, in the course of which we were informed, though not by himself, that our visitor 
was Abdallah, Sheykh of all the Haddadín in Mesopotamia, we bade Hánna bring what was left us of the fruit the Nawáb had packed for us at Kasmeyn, and which we had hitherto found a most acceptable present, when presents were required,for fruit is held in great estimation by the Bedouins. This we begged him to accept for " his house," that is to say his wives and family, the usual polite form of offering such a present; but the old man put them aside, not rudely but reproachfully, and saying simply "You would not take my lamb, why should I take these?"

We assured him lamely enough, that we did not know the present came from a Sheykh, (of course we could not say that we thought it had been sent for sale,) that we had no notion that the camp we had seen was that of Abdallah the Sheykh of the Haddadín, or we should certainly have alighted there, * and that in fine the lamb should at once be killed. The bystanders interested in the prospect of a feast, supported us in our explanation, and declared that it was satisfactory, and the good old man has gone away with his oranges and pomegranates. But I am vexed at our having made the mistake. The lamb has been slain and devoured. It is delightfully still to-night, after the Shammar camp of yesterday, with no sound in the desert

* An excuse for want of poiiteness on the ground of ignorance of the rauk of the person offended, though an additional offence with us, is always accepted as valid in the East. 
round us, but that of the camels quietly chewing their cud.

March 5.-The Haddadín, according to Sheykh Abdallah, have five hundred tents, the number, I expect, of those under his direct rule, for Hatmoud assures us that they are a very numerous tribe, three or four thousand tents he says. They have at any rate the appearance of great wealth, for besides a hundred camels which they keep for carrying their tents and other goods, they have a far greater number of sheep here, than we have seen together during our whole journey, except those perhaps on the plain of Melakh. The flocks began to pass our camp before it was light, and some of them must have been already out of sight, yet, counting them as we started, I made out at least twenty separate flocks, which may be reckoned as containing quite five hundred sheep each. In one which I counted there were over seven hundred. This gives ten thousand, in round numbers, as the property of only twelve tents. Some of these were probably only held in part ownership with the townsmen of Mósul; but, even if half were not theirs, this still leaves orer four hundred sheep each, a rery tidy property.

An hour after this, we turned to the right, and began to cross the hills by a well-worn pass in the limestone rocks, two hundred and fifty feet, according to my barometer, above the plain, and six hundred and fifty above the level of the Tigris at 
Howshweysh. We reached the highest point at half-past ten, and from it got a fine view northwards over the plain of Ninevch and the hills beyond Mósul, still white with snow. The descent was not rapid and, after one or two ups and downs, brought us to a smiling valley rejoicing in the quite inappropriate name of Wady Gehennem or Valley of Gehenna. There we overtook a party of Agheyl, with thirty or forty camels, encamped with their luggage in a sheltered place. They were delighted to see their comrades Nejrán and Ferhán, and made us stop and drink water with them. They had no coffee, and Wilfrid was given a narghileh. They were from Bagdad, and had been thirty-one days on the road, taking it easy on account of their camels. They had followed the river all the way. This gave Nejrán, who has begun to complain about our going on every day, and for such a long distance, a text for a sermon on overdriving the camels. But they have shown no disposition yet to give in, and keep well in flesh, so that I suspect it is more on his own account than theirs that he is anxious. He does not do half so much work as Ferhán, and insists upon riding one or other of the camels a great part of the day. He is a very little man, but inclined to be domineering, and to give his advice on all occasions. The other servants don't like him, and Hánna complains of his prodigious appetite. But we cannot afford to quarrel with him here.

The approach to Sherghát is "checrless cnough, as 
254 Bedouin Tribes of the Euphrates. [0I. xir.

is that of every other place with settled habitations in this country. Not that Sherghát has any houses, or anything more than a wretched little guard-house to boast of ; but Ferhán Pasha, as he is styled, has made it his fixed head-quarters now for three years past, and of course, every blade of grass has been eaten down, and every inch of ground trampled and bemired for miles round. A more dismal camp, not even excepting Aldershot, I never passed through, dirty and squalid and hideous. It makes one's eyes ache to look at it. The Pasha's tent is set on the side of a bare heap of refuse, one of the Mounds of Sherghát, and looks uncomfortably askew. It is surrounded by smaller tents, perhaps fifty of them, to give it a countenance, but in such a place a whole army would look mean. Here we have now alighted with the dreary prospect of a two days' sojourn before us, and I can afford to put off describing Sherghát and our reception at the Pasha's tent till to-morrow. 
1.6.14 I

air line

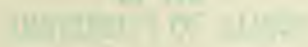




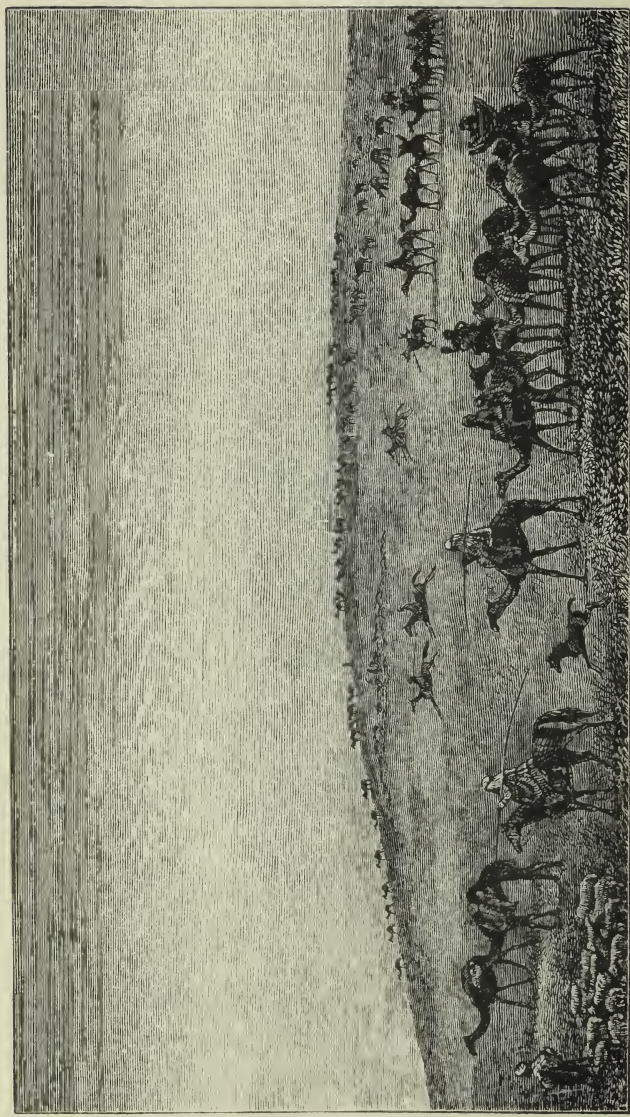

ப்

焉 


\section{CHAPTER XIII.}

"But what on earth brings you to Cub Castle?"

"They're fearless fules the young Osbaldiston squires."

"The sons were indeed heavy unadorned blocks as the eye would desire to look upon."

Rов Ror.

Ferhán's camp at Sherghát-His wives and sons-We diplomatiseWe start to cross Mesopotamia-Ismaill on horseflesh-We are received by Smeyr-His account of Nejd, its rulers, and its horses.

IF I had been born a Sfúk and called myself Ferhán, Sheykh of the Shammar, I would not give up life in the desert, even to be made a Pasha and to have $£ 3000$ a year paid me quarterly. Neither would I condescend to handle a spade, even in make believe, or go about with a tail of ragamuffins at my back, picked up from the offscourings of all the low tribes of the Tigris. I would not ride half bred mares or keep a rascally Mollah from Mósu to instruct my sons in Turkish, and-oh, a thousand times !-I would not live at Sherghát.

Of all wretched places this, I think, is the wretchedest; and it is just possible that Ferhán's residence here may be as much a make believe as all the rest, for he is away on a visit, they tell us, to Naï, that son of Faris to whom we have letters, 
256 Bedouin Tribes of the Euphrates. [сн. xir.

and nobody knows when he will be back. This absence, although at first sight it seemed to us a calamity, is after all perhaps the best thing that could have happened to our plans; for now we shall have the excuse of going after him, to cover our further journey into the heart of Mesopotamia, and once started, it will be hard if we don't go where we like.

We were received at the Pasha's tent with more than the usual frigidity of Bedouin etiquette, the absent Sheykh being represented by his son, a boy of fifteen, who either had not the wit or had not the manners to behave himself politely. He remained sitting when we entered, even after the salaam had been given, and pretended to be unable to understand a word of what we said or to communicate with us except through an interpreter, an empty form, as we do not know a single word of Turkish, and the interpreter's Arabic is in no way different from his own. By preserving a very solemn silence, however, in return for his: and by talking to others instead of to him, we managed to assert our position as people of consequence, and of course, as guests, we had a right to certain honourable forms, which there was no idea of denying us. Indeed, I am pretty sure that the boorish manner of Abd ul Aziz (for such is the young gentleman's name) is due more to stupidity than to any intention to disoblige, for this morning, as we remained in our tent till rather late, he has sent a message to 
Wilfrid to say that he hopes he is not offended and to invite him to coffee. There seems, too, to be every intention of complying with our wishes as to future proceedings, for the Nawáb's letter has been read, and it contains an especial request to Ferhán to forward us to any part of the Shammar country we may choose to visit. It is probable that the present of a cloak and a pair of boots at the beginning would have made all right, but it is rather late now, and Wilfrid considers it would be doing the young cub too much honour to invest him with a robe. Ali advises us to let the matter be, so we have limited our gifts to some sugarplums, sent to Ferhán's favourite wife, the person really in authority here, and who with her children is the only one, besides the mollah, actually living in the Sheykh's tent, Abd ul Aziz and his brother, Abd ul Mékhsin, another cub, being already married and settled in tents of their own.

Ferhán Pasha, because he is a Pasha, has been many times married, and he still has six wives, residing at Sherghát. These ladies have separate tents and establishments, and see no more of each other than relations are bound to do. Fasill, the youngest and the favourite, alone lives with him. She is the daughter of Sheykh Saadóun, a Kurdish chief from Upper Mesopotamia, and has two sons, Hámid and Beddr, three and two years. old. As Ferhán himself is the son of a Bagdadích, these little boys are consequently of very mixed 
258 Bedouin Tribes of the Euphrates. [сн. xiा.

origin and only to the degree of one quarter Arab in blood.

I went, on the afternoon of our arrival, with the Vakíl, or representative of the Pasha, Mollah Abdalláh, to pay the Hatóun Fasál a visit. I found her in the half of the big tent that is divided by an awning from the public part. She is pretty, with brown sleepy eyes and well-shaped, though rather large hands, very much tattooed. Her little boy Hámid, aged three, was playing about with first one, then another, of the crowd of people, men, women, boys and girls, who sat round a fire in a hole in the ground, on which stood a huge copper pot full of rice and meat stewing. Fasál rose and kissed me, and we sat together on a mattrass. Behind her was a cradle, out of which a girl handed her a very small baby wrapped in very dirty rags; she nursed it for a short time and gave it back to the girl. Then somebody uncovered the big pot and pulled out some lumps of boiled meat, which were given to the little boy Hámid to munch. All this time the conversation did not proceed ; the Hatóm seemed stupid, and I could not make much out of the Vakíl, who sat on my left. A little girl, Fasál's eldest child, named Shems, about five or six years old, had a nice face. A stir in the crowd opposite was occasioned by another lady coming into the circle; the secretary said she was Ferhán's sister Ariffa. All the rest of the company seemed to be servants, nurses, and 
inferiors. I was delighted when the moment came for leaving the harém, for the scene was one of squalor and discomfort. The men, uncouth as they are here, have generally something to say, but the women are without ideas, good-natured, but quite uninteresting.

I found Wilfrid sitting talking with a man from Hormuz, a suburb of Mósul, who is here on business, selling tobacco, and who knows all the tribes of this part of the country. From him and the mollah, and two or three others of the Pasha's retainer's he has been making out a list of the Shammar tribes, with an approximate table of their numbers. From this it would appear that the Shammar do not in all number more than eleven or twelve thousand tents, and their fighting allies and tributaries eight or nine thousand more. Perhaps they could bring twenty thousand spears into the ficld, if all could be got together.

Our dinner was served in our own tent, and was both plentiful and good,-búrghul, ragouts, lebben, butter, and well-baked bread. Two lambs were killed for us, Hánna says. After this, except for the incessant barking of dogs, we were left in peace.

So much for yesterday. To-day has been a weary one of idleness. We were taken to see the ruins, or rather mounds, for there is nothing above ground in Sherghát. These, they say, are just the same as those at Nineveh. Indeed Sherghát, 
according to Dr. Colville, is one of the Ninevite cities. To us they were quite uninteresting, though Wilfrid considered it his duty to rummage about in the tunnels dug by antiquarians on the chance of finding something new. These cannot have been made more than thirty years, yet already the history of them is forgotten, and they are held by the Arabs to be as ancient as the mounds themselves. We viewed a wolf away from one of them, but the ground was too broken for coursing him. The two young Osbaldistones rode with us, "Dickon the jockey, and Wilfrid the fool." They could not have been better represented-the one trying to sell us the mare he was riding, the other saying. nothing at all. I will say this however for Abd ul Aziz, that when Wilfrid questioned him about the breed of his mare, he admitted at once that she was. only Kehîleh, and, though the Mosulawi who was riding at his elbow suggested the addition of "Ajúz," the boy said, "No, she is not asíl-she came from Bagdad."

In the afternoon, Fasál returned my visit, while Wilfrid was out for a walk, with her sister-in-law and children, and followed by attendants, who all crowded into the small tent. The rakíl came too. Fasál evidently wished to be amiable, but I found it difficult to talk with her. She only once brightened up, when I spoke of her father, Sheykh Saadóun, who lives near Diarbekr. I offered them some of Mrs. Nixon's diamond-shaped white Bagdad sweets 
- they seemed to hesitate about taking any, when Hánna, who stood outside, said something about the sweetmeats being fit to eat, and the Vakíl Mollah Abdallah put in "shoghl Islam" *_-The children then, especially Shems, pounced upon the box and carried it off. Wilfrid wanted me to give a kefíych, and so I offered it, and by way of talking, said to the hatóm, "Please take it for the boy;" then it was explained to me that children's heads are always dressed in black †-however the kefíyeh was taken. The tent becoming too crowded after half-an-hour, I said I should be very pleased if the hatóun would stay longer, but that being tired I must now sleep, and then they all went away.

Wilfrid, during his walk, had come upon the Agheyl we had made the acquaintance with in the Wady Gehennem, and had sat down with them and eaten some lentil broth they had ready for their dinner, much to the disgust of a negro slave of the Pasha's who was with him, and who thought himself degraded by such company. The people here are a mongrel set, very few indeed of them real Shammar. We see no sign of the cultivation supposed at Bagdad to be flourishing here, but Abd ul Fettakh, the man from Hormúz, says there is plenty between this and Mósul.

All is, I believe, arranged for our journey to-

* Literally, "Mussulman lusiness."

+ For fear of the evil eye. 
morrow. The Mollah is evidently the man in authority here, and we have succeeded in making friends with him, at least to the extent of getting; him to help us in our plans. We have not said much about Faris, except in the way of inquiring his whereabouts. Nobody seems to know clearly about this, and, although they will not admit that he and Ferhán are otherwise than friends, there is certainly some mystery connected with him. Besides, it now appears that there are at least three Farises, and that the father of Naif is Ferhán's uncle, not his brother, and consequently not the one we want. We wish, however, to get away from Sherghát without delay, and have worked the ruins of El Haddr as a first stage on the road. These we declare we must and will see, and have appealed to the Nawáb's letter for assistance in doing so. Ferhán, too, is somewhere in that direction, and we talk of going on to him when we have seen the ruins. So it is settled that a man of the name of Ismaïl is to go with us, and see us safely to the Pasha, passing through El Haddr on our way. There has been the usual talk about Khôf, danger, and harámi, robbers, and ghazús, war parties, and if one were to take this literally, one would suppose the Shammar here, at their head-quarters on the Tigris, lived in daily terror of the Ánazeh. But we have long left off believing anything that we hear on this score.

March 7.- It was raining hard this morning. 
when we got up, but we would not be baulked of starting, and then Tamarisk was discovered to hare something the matter with her. Every two minutes she lay down and rolled, and then got up again. The Arabs said she was "mamósa," and that it came from eating too much barley after too much grass. It was probably a colic. They prescribed many remedies, and tried two or three; first a ropo was tied tight round the loins, then she was walked and run about, and then her tail was tied up with string, and lastly Ismaïl whispered a verse of the Koran into her ear. This secmed to do her good, and we started.

The people of Sherghát are fond of saying their prayers, a habit they have learned from their Sheykh, whose half-Turkish education scems to have affected the whole of the people about him. Our Agheyl, Nejrán, on the strength of this has become very obnoxiously pious, saying his prayers in and out of season, and giving us quite uncalledfor advice. He is also an idle fellow, leaving everything to Ferhán who loves hard work, insists upon riding instead of walking, eats till he is ill, and, what we most dislike, is always hanging about listening to what is going on in our tent. Ali, on the contrary, is growing more and more in our estimation, though less and less in fiesh. He keeps strictly to his place, does what he is told, and is clever in the little bits of diplomacy we trust him to manage. Hánna shows no sign of giving in, 
264 Bedonn Tribes of the Euphrates. [cr. xin.

and has lost all his fear of the Bedouins, if not quite of the desert.

Ill as we had been received, great difficulty was made about our going away, now that there was the excuse of the rain, but Wilfrid was firm, and Abd ul Aziz had his mare saddled and brought round to accompany us. I think, after all, they are not a bad sort of boys, only ill-educated and a little spoilt by their father's position. They don't like the Turkish language they have to learn, or the half-bred horses they have to ride, and would be glad to join their elder brothers, Eyssa and Mijuel, who scom such things and live in the desert like gentlemen. So there is hope for them yet. Abd ul Aziz managed even to get out a complimentary speech, at leaving us, in answer to one made him by Wilfrid, and smiled and looked gracious, as we rode away.

We have been travelling over a table land, on beautiful undulating soil thinly corered with grass and thickly with flowers, and intersected by deep ravines, at the bottom of which there is usually rich meadow pasture. Our course is due west, which answers exactly to the position of El Haddr on our maps, only that Chesney's general map of Arabia and Syria makes it fifty, and his particular survey* of the Tigris describes it as only twenty-eight miles from the river.

We have with us, besides Ismaïl, a black slave * By James Claudius Rich, British resident at Bagdad. 
and a boy and an old man in a turban on a donkey, all on their way to Ferhán, and taking advantage of our journey to get an escort. Ismail is very communicative. He tells us that it is perfectly true that Smeyr went to Jebel Shammar this winter, but he doesn't know what came of it. He says that the relationship of the Shammar in Mesopotamia and the Shammar in Nejd, of whom Ibn Rashid is one, is always kept up, and he seems to know all about the country, though he has not been there himself. He says that Ibn Rashid has thirty cannon and any number of guns, and is so rich that he sent three camel loads of gold to Mecea as an offering. There is no water in Jebel Shammar except in wells, nor grass nor corn nor anything but dates. The wells he said are as deep as from "here to that camel," eighty yards off, or, stretching out his arms, "forty times that." He says also that certain ties of relationship exist between the Jerba Shammar, his own tribe, and the Roála, and that the late Feysul Ibn Shaalán's mother was a Jerba. This would account for the proposed alliance of Ibn Rashid, Ibn Shaalán and the Mesopotamian Shammar.

Ismaïl is surprised at my linowing so much about the breeds of horses, and we had a long talk about them. I find he is quite as fanatical as everyone else about blood, although he says the Pasha and some of his followers affect to despise it. This is because Ferhán is a Turk and has spent eight 
years of his life at Constantinople, always talking Turkish in preference to Arabic, whenever he gets the chance. His sons were brought up in the same ideas, but the elder ones have broken loose and live away with the Arabs down towards Ana. The Turks have no thoroughbred horses of their own, and know nothing about those of the Arabs. He told us, however, that the Abéyeh Sherrák we had seen at Bagdad had really come from Ferhán and was really asíl. Formerly, Ferhán or his father had possessed a strain of Seglawi Jedrán blood, but it had died out. Ibn Shaalán of the Roála was now the only possessor of that strain, * and he appeared surprised and rather incredulous when I told him, what we have constantly heard, that Ibn Nedderi of the Gomussa and Ibn Sbeni of the Mehed both retain it. I then told him the story of the Valy's mare at Bagdad at which he laughed so loud and so long that I thought he would tumble off his horse. He lept on repeating at intervals during the day "Kehîlet Ajúz es Simri," "Irehîlet Ajúz es Simri," and every time with new bursts of delight. I wish Mr. Reubeniram could have heard him.

Having brought Ismail in this way to a high pitch of good humour we began to open ground with him about Faris. Here he was more reticent, and only answered our question, as to whether Faris and Ferhán were friends, by saying " they are brothers.

* This is incorrect. Ibn Shaalán's breed is Seglawi el Abd. 
Ferhán is Sheykh of all the Shammar, all, all!" One thing, however, we have ascertained, and that is that our Faris is not at all the same as Mohammed el Faris, Naïf's father, or Faris ibn Mohammed, Naîf's brother; so that we have been at cross purposes all along about him, and, even if Nôman had come with us from Bagdad, he could have been of no use to us. Faris too, it appears, is on the Khábur, not near the Sinjár hills; but we did not press the matter, as we must see how the land lies a little further yet.

The rain stopped soon after we started, but there has been a violent wind all day. Now we are snug enough in a deep wady, where there is grass and water, and where Wilfrid has got us some ducks and teal and snipe for dinner. There is no sign of inhabitants, and we are happy. Talking of Naïf, we mentioned Ahmet Aga and the letter we had from him; but Ismaill begged us to say nothing about it to the Pasha, as Ahmet Aga and he were "dushman," "enemies," linking his little finger's which is the Arabic sign for enmity, as putting the forefinger's side by side is that of friendship. "Enemies?" we asked, "and how?" He then told us that Ahmet Aga (a thoughtless young man) had, in attempting to cure Ferhán of shortsightedness (a common complaint among the Arabs), put the eye out altogether. He had poured sulphate of zine, or something of the sort, into the eye, without adding any water, and the eye was 
268 Bedouin Tribes of the Euphrates. [сн. хіI.

gone. I remember having heard the story at Bagdad. Now for a quiet night's rest.

March 8.-I suppose we did not manage more than twelve miles yesterday, but to-day we have marched nearly twenty. Wilfrid began the morning by pulling the tent down over the servants' heads, for, with the black man and boy, and the man from Mósul, and a shepherd impressed on the road yesterday as guide, there are rather more than he can manage quietly. This set them all in a bustle, and we got off at seven o'clock, the earliest start we have made yet.

We were no sooner out of the wady, and on the table-land again, than we found ourselves in a thick fog, which would have obliged us to stop if we had been without a compass. By the compass we determined the direction, and then kept to it by the wind, which blew from behind upon our right ears. It is curious how little faculty the Arabs have of finding their way. Their course seems to be directed entirely by what, I believe, sailors call "rule of thumb." Once out of their own district they are incapable of pursuing a straight line by the sun, or the wind, or any natural instinct. They travel from landmark to landmark and almost always in a zigzag, which costs them many a mile. Here they had to depend entirely upon us for the direction of El Haddr, a place we had never seen, or heard of till two days ago; and our knowledge of its position, though simple enough 
to us, secmed very marvellous to them. When the fog cleared, as it did in the course of the morning, they saw to their surprise El Haddr straight in front of them. It was still many miles off, but our course had been correct. I think this fog has been a fortunate circumstance, as it has raised us in the eyes of all our following, who now profess full faith and confidence in the Beg.

Soon after this, we descended to lower ground, and came upon a spring of rather bitter water and some Haddadín tents, where they gave us milk and told us Smeyr was straight before us, in the valley of the Sersár or Tharthar. These Haddadín are certainly one of the best-mannered tribes we have met, and are always hospitable and friendly; you are sure of a pleasant reception in their tents. All the country between the Scrsár and the Tigris is intersected with ravines and deep wadys, well watered and rich in grass. It surprises one very much to find it so thinly inhabited, but the population of the desert is no doubt fixed, not by what it can maintain in good years like the present one, but in seasons of drought or blight. The Sersár, howerer, is a perennial stream, and quite unlike any other we have seen in Asia. It flows down a well-defined valley meandering through rich pasture, and its banks are fringed with pollard willows, just as one may see many a stream in England, where it would have an evil reputation among sportsmen as a "stopper" in the hunting field. Sluggish and 


\section{Bedouin Tribes of the Euphrates. [cr. xir.}

deep, and with rotten banks, the Sersár is twentyfive to thirty feet wide and, at the ford where we crossed it, about five feet deep. There are very few places where camels can get across. Hagar went boldly in, without making any fuss, and my mare followed, and was off her legs and swimming for a moment or two. Hanna with his white donkey and Ali long stood shivering on the bank, and I have not yet heard how they managed to get over. We did not wait for them, but pushed on with Ismaïl to Smeyr's camp, which lay just beyond.

We stopped at the principal tent, where a little spare man of fifty, with grizzled beard, pale cheeks and an anxious expression of face, received us. At first, we doubted from his manner whether we were altogether welcome, but he made us sit down, and had carpets and cushions brought, and presently, after a few words in his ear from Ismaïl, among which I distinguished something about "bint el malck" (daughter of the king), his features relaxed, and his manner became more amiable. This was Smeyr, of whom we had heard so much as Ferhán's envoy to Ibn Rashíd. We then began to talk, first making the usual compliments of asking after our host's health and hoping that all was going well with him, and then inquiring about the ruins of El Haddr, which we professed a great curiosity to see. He said that he understood them to be interesting, and had heard that they contained sculptures and inscriptions, but he had nerer looked at them 
cir. xir.] I am the Danghter of a King. ' 27 I

himself, except from a distance. He should be delighted to show them to us, and added that we were the first Europeans who had come to El Haddr. He had known Mr. Rassam formerly, the English Consul at Mósul, and he inquired after him and the hatóun, Mrs. Rassam. They had never come to El Haddr.* A European had been sent two ycars ago to Ferhán at Shcrohát on purpose to see the ruins, but had not been allowed to procecd, as he was suspected of being a Muscóv. Europeans, he knew, were curious about such things. He then said rather abruptly to Wilfrid, and pointing to me, "Is it true that the hatoun is "ahsan' (better), than you ?" We did not understand what he meant, but Wilfrid answered, I suppose as a compliment to me, "Oh yes! far better." Whereupon he went on to say that he had heard as much, and that he was rery pleased to have the opportunity of making my aequaintance. We saw that there was a mystification somewhere, and we remembered certain hints to the same effect, which Ismaill had let drop in conversation to-day as we came along, and as soon as we returned to our tent we asked Ismaïl what it all meant. He then told us that he had heard from Nejrán that I was the daughter of a king, $\dagger$ and that, now the Beg

* In this Smeyr was mistaken. MIr. Ainsworth visited El Haddr in 1840 , and $\mathrm{Mr}$. Layard the year following, with $\mathrm{Mr}$. and $\mathrm{M} r \mathrm{~s}$, liassam.

+ The word "malek," though translated king, hardly conveys 
[CH. XIII.

had admitted the truth of it, there was no longer any reason for concealment. He had told Smeyr all about it, and implied that there was nothing to be ashamed of in the matter. In vain we assured him that it was all nonsense. He refused to belicve us, having heard the Beg say it with his own ears. It was not worth while disputing, so a king's daughtcr, I suppose, I must remain. Where Nejrán picked up his information I cannot think, but it may perhaps be accounted for by the presents giren me by the Nawáb. For to receive gifts is always a high proof of merit in the East.

Wilfrid is so much pleased with Smeyr's reception of us, that he has decided on giving him a mashlah, the one indeed he had intended for the Pasha; and he thinks that, by making friends with him, we may very likely be able to dispense with Ferhán's permission to go on to Faris. This would save us time and trouble, and we have no great curiosity to see this half-Turkish Pasha; besides which, if it is true that he is on bad terms with his brother, a visit to him might defeat our object altogether. In any case we don't know where Ferhán is, and a friend like Smeyr in the hand would be well worth two like Ferhán in the bush. With this view Ali has been despatched on a diplomatic mission to the Sheykh's tent, carrying with him a gold embroidered

to Arab ears what it does to ours. Any great independent Sheykh, like Ibn Rashid of Jebel Shammar, might take the title without adding much to his dignity. 
cloak, a pair of red boots, about three pounds of tobacco in leaf, and a box of sugar-plums for the harem.

I was interrupted by Ali's return. He has managed things capitally, having not only sounded the ground with Smeyr, but got him to agree to our wishes. There has been luck as well as skill in this, but I will not go into the details of his negotiation separately, but give the result as it now stands, after a conversation we have ourselves had with the Sheykh. It turns out then that, when he first saw us arriving at his camp, Smeyr was considerably alarmed, fancying that we were a party of soldiers sent to arrest him ; for some years ago, at the time I believe of Abd ul Kerim's death, he or his people killed some soldiers sent by the Government against them, and Smeyr has since then been "wanted" at Bagdad.

The Turkish Government have several times sent orders to their Pasha, Ferhán, to deliver up his cousin to them, but Ferhán has hitherto put them off by saying that he does not know where to find Smeyr. Smeyr, however, evidently mistrusts his chief, and is anxious to come to terms with those in power, fearing some act of treachery which should lead him to the gallows. Now it is a very common thing among the Bedouins, when they wish to make their peace with the Government, to get one of the foreign Consuls to intercede in their

VOL. I. 
favour, and Smeyr had already written to Colonel Nixon on the subject. He had, however, not yet had an answer, and he now fancies that our journey to El Haddr must in some way be connected with his own affairs. Ali, seeing its advantage to our plans, has done his best to encourage the idea. Without going so far as this, we have expressed our readiness to do anything we can for him in the way of interceding in his behalf with Colonel Nixon, or of carrying letters or treating with Husseyn Pasha for him when we get to Deyr. He sees very plainly that we have nothing to do with the Government, as we have no soldiers or zaptiehs, or any representative of authority with us, and that we wish him well and may perhaps be able to help him. He was delighted, too, we hear, with the cloak, the like of which has not been seen in this part of Mesopotamia within the memory of man, and Hánna's description of the way it was handed round in the tent, and felt and tried on and admired, is very satisfactory. Finding him in such excellent dispositions, we have told Smeyr frankly what it is we want, and he has answered, I fully believe, as frankly, - certainly very sensibly.

In the first place, we are to see El Haddr, which it would be a pity to miss, as we are so near it, and then we are to make our way, without turning to the right or to the left, for the Khábur, a small river which runs into the Euphrates below Deyr, and somewhere on the banks of which Faris is 
known to be encamped. This is about a hundred and thirty miles as the crow flies, and of course desert all the way, but he will send a trusty man with us, the same that he took with him to Jebel Shammar this year. With regard to Ferhán, Smeyr insists that we must go to him, if we hear that he is anywhere near our line of march, and this of course we should feel bound in any case to do after having enjoyed his hospitality at Sherghát. We must also keep on Ismaïl, the Pasha's man, as Smeyr is afraid of giving offence by allowing us to send him back. As to his own man, he is to have ten mejídies (£2) as "akhrám" (reward, literally "honour," like the French "honoraires") for the job. To all this we have consented, and have thanked Smeyr most cordially for his help.

We are now on a more confidential footing with him than we have yet been with any of the Arabs, and we have made use of it to ask him for particulars of his visit to Jebel Shammar. With regard to his own adventures, we cannot get him to say much, which looks as if he had not been too well received by Ibn Rashid, in fact we know his mission failed; but he talks freely enough about the country and the people in it, and, what wo most wanted to know of, the horses. I will put down as nearly as I can recollect what he says: Jebel Shammar, he affirms most positively, in spite of what Dr. Colville told us of its being a single conical peak, is a long range of hills 
276 Bedouin Tribes of the Euphrates. [сн. хиI.

higher than Jebel Hamrín,_-"like Jebel Sinjár, only higher still." Rain falls there in the winter and sometimes snow. There are, however, no springs or water of any sort above ground, but plenty of deep wells, and he makes use of the same mode of describing their depth as Ismaïl did, by a distance along the ground, which is curious.* The people of Hîyel and the other towns, and their Sheykh, Ibn Rashid, live most of the year in houses, but during the winter and early spring go out to the mountain, and then they inhabit tents. There is plenty of grass at that time of year, that is to say for three or four months, and the mares then live out as they do here, but for the rest of the year they have to be fed on barley, of which there is but little, or more commonly on dates. There are no trees, if we understand him rightly, but the palms, and no cultivation but the gardens round the towns.

About Ibn Rashid, he said that he was a Shammar, and he talked of him as the Sheykh (not King). He was Vakíl to Ibn Saoud of Riád,_- "as it were, his cavass," - but very rich; and he repeated the story about the three camel loads of gold sent to Mecca. Ibn Saoud was King of all Arabia. We

* Arabs, when drawing water from a well, fix a tent pole or other piece of wood across the mouth and then draw up the leather bucket by a rope over it, not gathering the rope in coils as we do, but running with the end of it as far as is necessary to bring the bucket to the top. They naturally, therefore, measure the depth of a well by the distance the rope is trailed along the ground. 


\section{PEI}

B. - Only those strains of blood which possess dou now used for sing a horse not haduid is disqualified aled hadud. The produce are duce of a hadud hisqualified as thorong The produce of is called Ibn or Bint he out of a disqualified or . The proand is equally disquelifin, the son or daud or kadishe mare

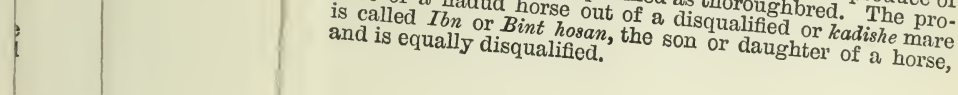

$\mathrm{Ke}$

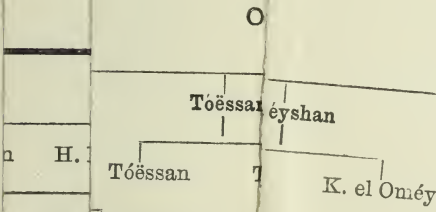

A. $\mathrm{H}$

Bulád, of whis is said was $t$ Arabian, * at im, but in the $m$.
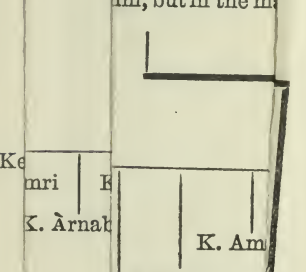

K. Jennáh ed azáli

horoughbred

* The celebr breed. certain this $\mathrm{f}$

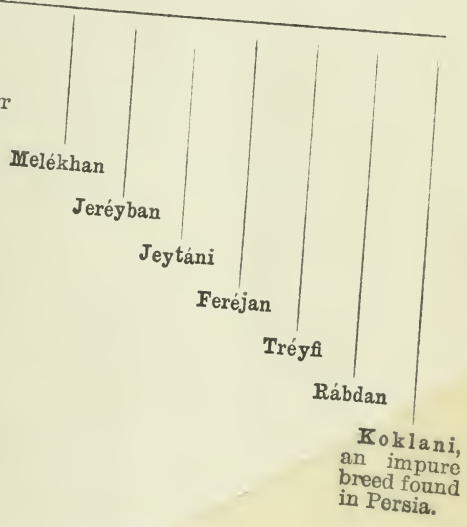

To face Page 276. 


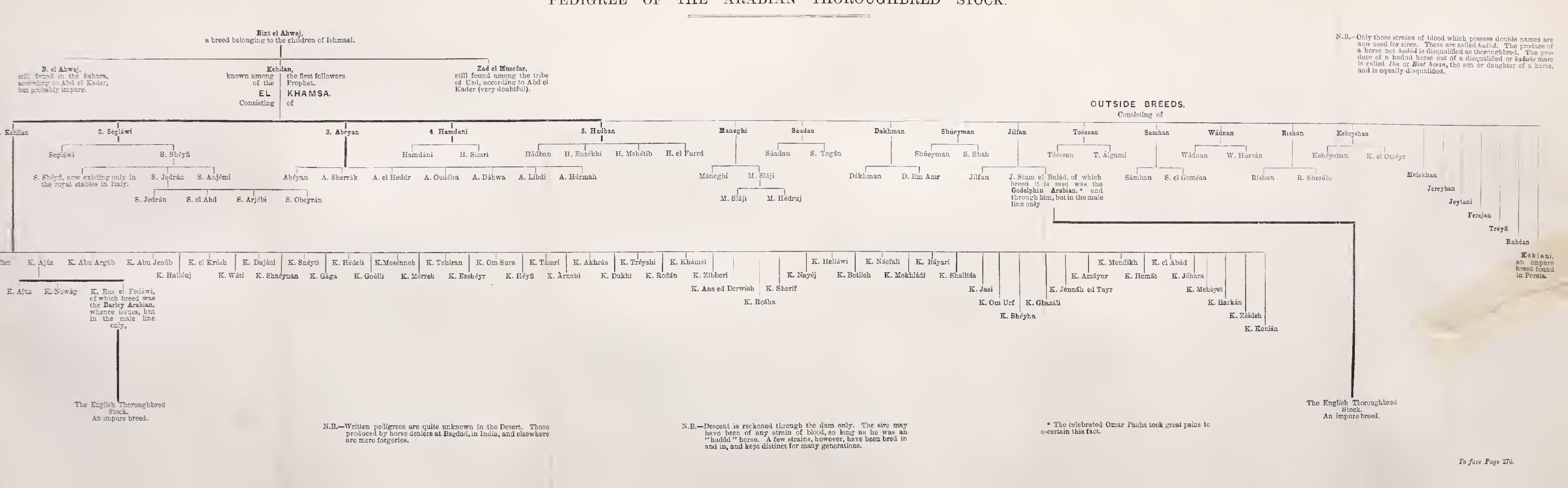


asked him for an introduction to Ibn Rashid, but he is evidently not on such terms with him as to give this. He added to Wilfrid, "If you were my brother, I would not advise you to go near Ibn Rashid. He does not like strangers. If you were to go to Hîyel to look about you (fúrraj), as you do here, he would think you had some evil purpose."

Wilfrid then inquired about the horses or rather mares in Jebel Shammar, and asked if the Arabs. there had the same breeds as the Mesopotamian Shammar. "Just the same," he answered. "They have Keheîlehs and Jilfehs and Dakhmehs and Meleyhas, just as with us. There are not many horses (kheyl) bred there. Ibn Rashid buys all his from the Bedouins-the best from the Ánazeh. There are few horses in Hîyel, and they are dear. This is because there is no pasture for them the greater part of the year, as there is in the North." Wilfrid: "We have heard that in Nejd there are horses of a different breed from any you have here, or rather that the Arabs there make no account of breeds" (alluding to Palgrave's account of the Riád stables). Smey": "Whoever told you that told you 'kidb' (nonsense). There are no breeds in Nejd but the breeds of the Bedouins, Segláwi, Jilfan, and the rest. Ibn Saoud, if he has any horses, gets them all from the Bedouins. There are good horses in Nejd and asíl (thoroughbred), but the Ánazeh horses are the best." He had never heard of any Nejd breed. "All Bedouins have the 
278 Bedouin Tribes of the Euphrates. [сн. хіIr.

same breeds of horses. There are none other asíl." He had brought a mare back with him from Jebel Shammar, a Jilfeh Stam el Boulád, for which he had paid, besides another mare he had had to get rid of, five camels and twenty sheep, but horses were dear at Hiyel. He had known mares from the Shammar fetch as much as twenty camels when sold there. He took us to look at this mare, which was standing just outside. She is a chestnut with three white legs, not particularly handsome or more than fourteen hands two inches in height.

On the whole, we are pleasantly impressed with Smeyr. He is a gentleman, though not of a very refined, still less of a very romantic type. But he has the politeness to perceive when we wish to talk and when we wish to be alone, a thing we have not met before. He has not been inside a town for many years, and seems more like a man of the world who has forgotten part of his manners, than a rustic born and bred. He is quite without pretence, indeed rather less dignified than he should be; but I fancy he is poor and bullied by Ferhán and his sons, at least Ali says as much. I can't quite make out what his relations with Faris are. There is certainly a coolness, if not worse, between Ferhán and his brother. Smeyr is first cousin to them both, his mother having been a sister of Sfúk. He has a younger brother, Ghathban, living here in a separate tent, and several grown-up children, all by the same wife, for he has only one. The men 
here are very different from those in Ferhán's camp, being, I should say, quite pure Shammar. They are well behaved, merry, good-natured people, and do not crowd about our tent or ask tiresome questions. They seem poor, much poorer than the Haddadín, and have but few mares. The only very talkative man in camp is a Mosuláwi, a striking contrast to all around him. He is a young man, fat, smooth-faced and red-haired, with a curious mincing accent, and great play of pudgy white hands in speaking. What he is doing here I can hardly make out. But Wilfrid has bought some tobacco from him, and I see him sometimes writing letters, and sometimes mending clothes for the Arabs. Perhaps he is a general trader. They seem to like him, and sit open-mouthed listening to his interminable stories and accounts of what is going on in the world, tales of the war, the Muscóv and the Sultan. The Shammar are much more "Turkish" in their sympathies than the Arabs we met on the Euphrates, and this, I fancy, is because they are more pious. Smeyr and most of his people say their prayers regularly, and one of the first questions he asked was whether we were Muscóvs.

Smeyr's wife, Sukr (Sugar), is a middle-aged person of well-bred appearance, and possessed of an intelligent, pleasant face. She received me, when I called this evening, with all possible honour's, cushions, pillows, dates, butter and the rest of it. There were with her several sons and daughters, 
a son's wife, a grandchild and a son-in-law, besides a brother who came in while I was there and kissed her, and then sat with his arm round her neck. A huge caldron of camel's milk was simmering on the fire, and rice was being added to it every now and then from a basket. At other fires other caldrons were full of meat. Three large camelsaddles and some dirty mattrasses were the only furniture. I like these people better than those of any harem I have seen. They are simple, merry, and kind.

But this is surely enough for to-day. 


\section{CHAPTER XIV.}

I said to Time, "This venerable pile,

Its floor the earth, its roof the firmament,

Whose was it once?" He answered not, but fled

Fast as before. I turned to Fame, and asked

"Names such as his, to thee they must be known.

Speak!" But she answered only with a sigh,

And, musing mournfully, looked on the ground.

Then to Oblivion I addressed myself,

A dismal phantom, sitting at the gate;

And with a voice as from the grave, he cried,

"Whose it was once I care not ; now 'tis mine."

ROGBRS.

The city and palace of El Haddr-We are mobbed in the ruinsSmeyr sends us on our way-We put our house in order and march westwards-Quarrel with Ismaïl-He leaves us-We discover salt lakes-A wade through the mud-A silly old man-Faris at lìst.

March 9.-We have been spending the day at El Haddr, and have been far more interested than we thought to be. It had been agreed overnight that Smeyr should move his camp, and we ours, to the ruin to-day; so, as soon as we had had coffee and made arrangements with Hánna for the day's march, we started. It was but three miles, and we galloped all the way, leaving Smeyr and a couple of his men who were riding with us far behind. Their mares had lately foaled, and they did not care to press them.

As we came near the ruins, we were surprised to find a really large city in tolerable preservation, with 
282 Bedouin Tribes of the Euphrates. [сн. xiv.

great part of the walls and towers and even some of the houses still standing. Its situation is a charming one, in the desert it is true, but in a desert which might easily be mistaken for one of those great rolling downs one sees in Wiltshire, only that here a multitude of flowers are mixed up with the grass; scarlet tulips the counterpart of our garden ones, purple stocks, marigolds, and a pretty blue flower called by the Arabs bohátteyr. In all the hollows there is now thick grass, pasture sufficient for twenty times the number of flocks there are to eat it; and the ruins rise out of a bed of green, like ruins preserved for ornamental purposes in England. The town is nearly square, and covers perhaps an area of two miles. The walls and fortifications are of massive hewn stones. They seem to have been overthrown, in part at least, by earthquakes, for in many places there are deep cracks in the masonry indicating a "settlement" of the ground beneath them. The houses, such as still remain standing, are merely square blocks without internal divisions or more than a single doorway, and a hole or two high up to admit light. Their roofs are arched, and remind one a little of the more modern houses of Syria. They belong, however, certainly to classic times, and there is little or no appearance of the city having been reconstructed, as so many were, by the Caliphs.

In the centre stands the palace, a really noble building. The outer wall enclosing it, like every- 
thing else in $\mathrm{El} \mathrm{Haddr,} \mathrm{is} \mathrm{rectangular,} \mathrm{and} \mathrm{each}$ face of the square is perhaps a quarter of a mile in length, and as solidly built as the walls of the city itsclf. The courtyard thus formed is perfectly level, and appears to have been paved throughout. Within stand several buildings, temples, arches, and single columns and, towering over all, the palace itself. This, as I have said, is really imposing, and has a façade towards the East, which in the day of its glory must have been the principal wonder of this part of the world. In idea it is not unlike Ctesiphon, except that, instead of a single open court of gigantic dimension, there are here four smaller ones; but the arrangement is similar, and each hall leads by a low door to a suite of smaller apartments beyond. The principal of these halls of audience, for such they undoubtedly were, is ornamented with pilasters, bearing on each of them a group of three human faces carved in stone. Above, runs a cornice of the common egg and tongue pattern, and then there are the remains of a vaulted roof springing from a second cornice. The faces are not in the purest style of art, but are sufficiently well cut for decorative purposes, while the mouldings and architraves of the doorways are more carcfully executed and are very beautiful. I have taken drawings of some of these. They would make beautiful chimney-pieces, if one could get them to England. Three of the faces have been carefully cut away with a chisel and are gone. 
284 Bedouin Tribes of the Euphrates. [0н. xгv.

To me the most interesting part of the palace is the suite of inner rooms, lying behind the halls of audience, for some of these are quite perfect and in such " habitable repair" that, with a little sweeping out and clearing away of rubbish, one might go in at once and take possession. One room in particular would pass without much comment in London as a dining-room, with its coved ceiling, Corinthian cornice, and handsome architraves. One can see that the walls were intended for tapestry, for below a certain height the stones have been left rough, while above it the surfaces are nicely polished. The whole palace is built of a handsome red sandstone,* which is so well preserved, especially in these inner rooms, that the masons' marks are still perfectly distinct. They look like the letters of an alphabet -but what alphabet? On one of the walls there is an inscription in Arabic, and another in a character similar to the masons' marks. The building is admirably finished-each stone beautifully fitted to its neighbours, without flaws or spaces, or any "scamping" of the work. Here we have wandered about all day drawing and taking measurements; but it is impossible to give a correct idea on paper of the beauty of all that we have seen. Nobody here knows anything of the history of El Haddr, neither do we.†

* Brought from the Sinjár hills. The natural rock of El Haddr is a friable limestone.

+ El Haddr is no doubt a Greek city of nearly the same date as 


\section{* $\quad$ * $\quad$ * $\quad$ *}

We were driven from our meditations in the palace, by an invasion of the youth and fashion of Smeyr's camp. They had finished their work for the day, the work of pitching tents and unpacking household furniture, and were now at liberty to spend an idle afternoon in the noisy fun which Bedouins love. At first they left us unmolested, and merely ran about the ruins laughing and shouting, but by degrees they gathered round us, and, as it is not the custom to refuse one's company to any who wish to share it, we soon found ourselves in the midst of a rather uproarious mob.

The men were civil enough, and perhaps the women meant to be so, but they and the children pressed so closely round me that I had to give up my drawing, and escape as I best could to the top of a pile of broken columns under a wall. Even there they followed me. Some of the girls were really very pretty, with bright laughing faces and teeth like pearls. But the old women would insist upon handling and pulling at my clothes, to feel what they were made of, and the children would not be repressed from sitting almost in my lap. Meanwhile, the older boys had begun to throw stones at the carved faces on the wall, great fun

Palmyra. It is mentioned by Benjamin of Tudela as still existing on the road to Bagdad. It was possibly destroyed finally by the Tartars. Palmyra was as uninhabited as El Haddr a hundred years ago. 
no doubt for them, but distressing for us to look on it. Fortunately the natural stone of El Haddr is softer than that of the buildings, and no serious damage was done while we were there. Only the stones began to fall in a rather reckless way, and as the elder people, who might have maintained order, were away, Wilfrid thought it best we should retire before an accident happened. So, putting the best countenance we could on our retreat, we said good-bye to the ruined palace. I confess I was glad when we got back without mishap to the camp. Smeyr excused his people's behaviour, when he heard of it, by remarking, if I may translate it into Scotch, that "it was only the laddies."

He has been asking us for medicine to cure his eyes, which have little the matter with them except shortsightedness, and we have been at some pains to explain that we have nothing which will cure them. He asked us for "sugar of Egypt," meaning, we supposed, sulphate of zinc, which we happen to have; and at first we thought of letting him have some, till it appeared that he intended taking it internally. The word "poison," however, has nearly frightened him out of his wits, and he begs for something else. He complains too, as many do in this country, of indigestion, and no wonder, when one thinks how the lives of Bedouins are spent between starvation and feasting, and of the mass of indigestible curds and ill-baked bread 
they devour. We have compromised matters, and made him happy with half-a-dozen blue pills. Tomorrow we are to bid him good-bye.

Sunday, March 10.-I am afraid we were not altogether as sorry as we should have been when we took leave of our host this morning. Smeyr has been very kind to us and has fallen in with our plans in a way we had no right to expect of him, and which may yet cost him some trouble with his Sheykh,-and all without any clear prospect of return at our hands. Nevertheless, we could not manage to feel regret at going. The fact is, life in an Arab camp is terribly irksome, and the thought of exchanging the forms and ceremonies of Bedouin society for the freedom of the uninhabited wilderness was too much for us. We could hardly conceal our joy. Fortunately gratitude is not an Oriental virtue, and to eat and drink with a stranger, and then to go away without wishing him good-bye, is quite in accordance with the best manners, so a little demonstration in our farewell went a long way. Smeyr's last words, too, relieved us in part of our sense of obligation, for it was a request that we would send him a pistol from Deyr, "to protect him," he said, "from the soldiers, - a revolver with five chambers like the Beg's." This we made him a conditional promise to do,-conditional, that is, on our having a pistol to send and a chance of sending it. At the Pasha's tent we had given liberal tips to the 
servants, as if we had been staying at a house in Bagdad, but here nothing was expected beyond the conventional crown-piece to the coffee-maker and a shilling to the man who held our stirrups. So amid benedictions we departed.

At first our way lay through the ruins, which I find more extensive westwards than I had imagined yesterday, and we may have been half an hour before getting clear away. Our course to the Khábur we knew should be west-north-west or west by north, and towards the latter point we steered, Daëssan, Smeyr's confidential guide, a little old man nearly blind leading the way. The first thing, however, to be seen to was to put our camp in order, for we are now on a serious, if not a dangerous journey, and cannot afford to hamper ourselves in any way, and Wilfrid at once proceeded to weed our party of its useless components. The Kurd, the black man, the boy, and the shepherd still dogged our steps, and showed no sign of an intention to leave us; and leave us we were determined they should. However, on the principle of dividing a bundle of sticks, Wilfrid deemed it best to get rid of them in detail, so, riding up to the four, who were together, he asked them what they wanted and where they proposed going.

"We are the Pasha's servants," they said, "and will travel with you till we get to his camp."

"And this 'felláh," " (pointing to the Kurd) "is he the Pasha's servant too?" 
"Oh no," said the others ; "he is only a Kurdish tájer, a merchant going to sell tobacco."

"A Kurd, indeed!-a merchant!—a felláh! I cannot have such people with me. It is a disgrace to the camp. Let him be off!"

This suited the prejudices of the other three, who, according to Bedouin custom, naturally despised their fellow-traveller for his city origin, and they made no more ado, but abandoned him to his fate. With as terrible a voice as he could command, Wilfrid bade him begone, and the man, after appealing a little and lingering a little, obeyed. As he went he called on the shepherd to follow him, for I fancy the two had come to an arrangement beforehand, and so we got rid of them both. The shepherd, whom Wilfrid had made friends with, and who had been useful to us in naming plants and occasionally lending a hand in loading and unloading the camcls, came very civilly to say good-bye, and Wilfrid made him a trifling present, which he evidently did not expect, for he looked up in astonishment at the piece of silver, and then, invoking blessings on us and ours, kissed our feet and ran after the Kurd. We could see them for nearly an hour afterwards travelling, the one on his donkey, the other on foot, towards the southwest.

The negroes, now left alone, assumed a very humble tone, and for the first time made a show of being of use, and, as the elder is really a servant

VoL. I. 
of Ferhán's, we have let them follow us for "one night only,"-being pretty sure that they will leave us when they find out where we are going. The negro slaves give themselves immense airs. among the Bedouins, affecting, what is quite opposed to their character elsewhere, a grave and solemn demeanour. This comes in part from their having always lived in the tents of Sheykhs and zreat people, and having been generally brought up. as companions to the boys of the house, and partly from their being stricter Mussulmans than their masters. They are treated by these on a footing almost of equality. At any rate, they have considerable influence, and come and go and sit down with the rest just as it suits them, so that, unless we are to quarrel with Ferhán, it will be as well to conciliate his blacks. Still we are travelling. in a barren land, where water has to be carried. as well as food, and extra mouths are a burden. In any other countries but these, parasites of this. kind would endeavour to propitiate those they live on by making themselves useful, but here nothing of the sort can be expected. Neither the black slave nor the Kurd have ever deigned to put their hands to a rope, or so much as minded a camel, while the boy squats in the tent as soon as it is pitched, and laughs impertinently if told to move, and on the march complains loudly if he may not ride one of our camels. Yet this little negro is a mere outcast, left behind by a caravan some 
months ago, and living on charity ever since. He is now on his way, he says, to his friends at Deyr.

This matter of camp followers settled, our next anxicty was to come to a clear understanding with Daëssan, as it had not yet been formally announced to Ismail that the Pasha's camp is but a secondary object in our journey, and that Faris and the Khábur are really our destination. To manage this it was necessary to get Daëssan alone, so I was deputed to engage Ismaïl in conversation and linger behind, while Wilfrid rode on and settled matters with our guide. It is just as well that we did this, for it turned out that Ismail had already been at Daëssan on the subject of our route, and the old man had been half persuaded to give in to him. But, now that he clearly understands what is expected of him and what he has to expect of us, I think we may depend upon his loyalty. He seems, however, to be afraid of Ismaill, who is a great big bullying sort of a fellow, and he requires the constant support of our presence to keep straight upon his course, instead of following Ismaill, who is always edging away to the south. It is lucky that we are accustomed to desert travelling, or we should be entirely in their hands; but, by dint of perseverance and constant attention to the position of the sun, we have managed to make a capital march of it to-day, nearly thirty miles, and all in the right direction.

Objects of interest there were few on the road, an old track leading from Mósul to Ána, and 
another from Mósul to a súbblica or salt lake called Ashgar, being the only interruptions to our pathless course across the plain. A caravan, we are informed, travels once a year along the former of these two roads, accompanied by a mixed escort of Shammar and Ânazeh to protect it, on toll paid, from ghazús; and the latter is an occasional route for parties sent by Government to get salt. Ashgar is three days' journey from Mósul, but long days, as from the point where we crossed the track it was seventy miles as the crow flies. About the middle of the day we sighted some camels on the horizon, and there was the usual alarm of a ghazú ; but the caravan, if it was one, went its way without exchanging signals with us, and shortly afterwards we came to the edge of a large brackish lake, on which immense flocks of flamingo (naaj) were feeding. This, Daëssan informed us, was the Súbblkha Ommuthsiábeh. It is three miles long by one broad, the greater length being from north to south, and we skirted its southern shore. It and another lake, still larger, called Ubuára (twelve miles long Daëssan said), are fed from small streams issuing from the Sinjar hills, and have, except in the driest seasons, water fit for camels, though not for other animals. Not far off we came upon a small camp of Haddadín, where the women gave us milk, their husbands being away. It was the hour of afternoon milking, and the fresh sheep's millk was very refreshing, for we had had nothing all day. 
The women were gossiping, good-natured creatures, and very pleased to get an opportunity to talk.

Still we went on, Ismaïl becoming very restless, and looking out constantly over his left shoulder, and declaring that we were going the wrong way, in spite of all our attempts to engage him in conversation; but fortunately he is mounted on a wretched kadísh and cannot get on ahead of us, so he has to be content with complaining. It rery nearly, howerer, came to a crisis, when, from some rising ground, he caught sight of tents far away to the south-west, which he declared must be the Pasha's. "Ya beg, ya beg," he cried, "they are there, the Jerba, the tents of Naif and Ferhán." But we would not listen, saying there were only fourteen tents, for we had counted them, and maintaining that such a camp could not possibly be the Pasha's. "At least," he pleaded, "we shall have a lamb to eat there and bread and lebben, while further on there is nothing but chôlnothing but chôl"-giving the doleful accent to the word which townsmen use when talking of the desert. Still we paid no attention to his remonstrances and went steadily on, the camels doing their work brarely at the rate of three miles an hour.

The best way to manage camels is to keep them going at a steady pace all the morning, for they do not care to eat during the forenoon, and then, when the sun begins to decline, to let them feed as they 


\section{Bedouin Tribes of the Euphrates. [cr. xiv.}

go. This of course delays them a little, yet our camels will march feeding at the rate of two and a half miles in the hour. At least two hours before sunset they should be allowed to stop, and turned loose to get all they can before it is dark. If there is a moon they will go on grazing half the night, otherwise they must be collected round the tents during the last minutes of twilight, when they will sit quietly chewing the cud all night. They require no water during the winter (ours have not touched a drop since they left Bagdad), or as long as they get grass during the spring; but if fed on beans, as they are in Egypt, they must drink at least every four days in warm weather. Here they get no food at any time but what they can pick up.

To-day we have done much more than a usual march, and it was five o'clock before the tents were pitched. We had some difficulty in choosing a proper spot for camping, as the latter half of our day's journey had been across a barren tract of land; but, just as we were beginning to despair of finding better, Wilfrid espied a tell some way off the road, which he thought looked green, and galloped off to it, and sure enough it was covered with bohátteyr, a green plant with a blue flower, like nemophila, which horses and camels alike appreciate. Here we are now, and a delightful spot it is: a single mound in the middle of the plain, rich in this herbage to the top. Half way up there is a fox's earth, and below, a colony of 
jerboas, which this warm evening are sitting at the mouths of their burrows looking at us in astonishment.

March 11.-To-day matters came to a crisis with Ismaïl, and he is gone. The two blacks also have left us. All last night and this morning Ismail was working the old tales of danger and ghazús, expatiating on the terrible nature of the desert north of us, contrasted with the delightfully inhabited regions of the south-want of water, want of grass, want of "Arabs," of all except plundering bands of Ánazeh, who, by his account, perpetually scour these inhospitable regions, robbing and slaying those who venture there. Ali and Hánna and the two Agheyl were much impressed by these sad stories, and even Daëssan occasionally chimed in, "He did not know the road; he did not know whom we might meet; he did not know where we should find Faris. Perhaps it would be better first to go to Ferhán, or at least to Naï, who would send people with us. It was not all quite right between Ferhán and his brother; the Khábur was clean out of our road to Deyr," \&c., \&c. The weight of public opinion in the caravan was against us; and all we could say in support of our views was, that the camels were ours, and that those who liked might leave us. Of this, of course, there was no question among our own people, and Ismaïl was evidently loath to part with us, not, I fear, from affection, but from love of the backshísh he had so nearly earned. 
296 Bedouin Tribes of the Euphrates. [ci. xiv.

We had no sooner started than it became evident that Daëssan had been "got at" during the night, for he no longer kept his course fairly, but suffered. Ismaïl to lead him astray whenever our attention was directed elsewhere. Excuses were easy to give for this: "There was a súbblha in our way which would have to be turned by a circuit to the southwest; we had come too far to the north yesterday; he must go a little to the left to get his bearings." The contest between Wilfrid and Ismaill soon almost became a physical one for the possession of the little man, one riding on one side and the other on the other, and each trying to edge him off to right or left, like the spirits of good and evil tempting a human soul. At last the crisis came. Ismaïl having stopped behind for a few minutes to say his prayers, Wilfrid profited by this to get a good point northwards, so that when Ismail succeeded in overtaking them he was so much out of temper that he declared he would go no further. The black man and the boy were already gone and out of sight, having made away nearly due south; so a halt was called, and we all sat down on the ground to discuss matters. The strong point of our case was, that physically we could do as we liked, and were free to turn the camels' heads to any point of the compass we chose; the weak one, that we could hardly go without introduction of any kind to Faris, and it was necessary that one or other of the Shammar should remain with us. Ismail's strong point was 
the desire we had always expressed of paying Ferhán a risit, and the shame (aïb) it would be to pass so near his tent without stopping. The conversation, then, was something of this sort. Ismaïl: "You do not wish then to see the Sheykh? Ferhán will not be pleased." Wilfricl: "We wish to see him, but where is he?" Ismaïl: "Out there with Naif," pointing semicircularly round half the southern horizon. Wilfirid: "And Faris, where is he?" "Away on the Khábur, close to Deyr," pointing in almost the same direction. Wilfrid: Nonsense, that is the road to Anah. I have an engagement to meet a friend at Deyr in five days, and I want to see Faris." Ismaïl: "Fire days! it is quite close. The Pasha will send you there tomorrow." "But where is the Pasha?" "You see that hill on the horizon: come with me there, and I will show you his house." "Let us go ; but mind, if I don't see it, good-bye."

There was not much danger in making this promise, and although the hill (or rather the little indentation on the horizon) was some five miles out of our way, we thought it prudent to go so far with Ismaill, that we might not seem unwilling to sce his master, whom we have no wish to offend (and passing close to a great man's camp without stopping is a serious matter), so we altered our course, and now held on nearly straight to the south. Ismaill seeing he had gained his point had become good-humoured, and we, wishing to part 
friends with him, explained the difficulties of our position as to Faris and his master, both of whom we had not time to visit. If the whole truth must be known, one of our principal objections to meeting the great man was, that we had only one gold embroidered cloak left, the one destined for Ferhán having been given to Smeyr, and we did not like to appear empty-handed at his tent. Daëssan followed in silence, for he is not much addicted to words, and Ali and the rest of our followers were of course in high delight. "In another moment we shall see the tents," exclaimed the enthusiastic Hánna, "a lamb will be killed, perhaps a young camel, and we shall at any rate slecp among the Arabs to-night!" "Inshalláh" they all chorused, and so we rode on.

The little hill, on nearer approach, turned out to be nothing but a mound transfigured by the mirage, and made to look great only from the surrounding level of the plain. Beyond it, however, the ground sloped away rapidly; and, in truth, it commanded a very considerable view. Here we halted, straining our eyes in every direction for the vision of black dots which should represent an Arab encampment, but nothing was visible for miles and miles. Ismail, however, was not so easily abashed. On the far horizon, perhaps fifteen miles away, rose a flat-topped hill easily recognisable, and very likely really recognised by him. To this he pointed triumphantly: "There," 
he said, "is the house of Naiff, and there the Pasha abides."_-"A day's journey," we replied; "you will get there to-morrow, but we must go on our way."- "At least," he pleaded, "go a little way towards it, as far as the tent you see down there." We knew there was no tent, but the object he pointed to was not far off, and we agreed to satisfy him, so, bidding the caravan wait, we galloped down the sloping plain. The object, on nearer inspection, proved to be a pile of bushes marking the spot where a tent had been, but long ago.

Just as we made this out, a string of camels hove in sight a mile or two away. Ismail seemed alarmed, declaring there were horsemen with them, but we could see well enough this was not the case, and galloped on towards them, wishing to set the matter at rest as to the whereabouts of the Shammar, for the party seemed to be travelling from the south. We were determined, too, to get our information unadulterated by Ismaïl's colouring, and so let our mares out, and left him on his old kadísh well in the rear. As we rushed up to them at full gallop, with guns in our hands, it is not strange that the people with the camels should have been a little alarmed. They halted and formed squarc, as I may say, to receive our charge. They were ten men on dromedaries, armed with lances, but they had no fire-arms with them. We pulled up a few yards in front of them, and asked them whence they were and whither going; to 
300 Bedonin Tribes of the Euphrates. [сн. хाv.

which they replied that they came from Ferhán, and were on their way to Tell Áfar, a town of the Sinjár, to buy corn. The camels were not laden. They informed us that Naif's camp was, in truth, a little way beyond the flat-topped hill, the name of which was El Melífeh, but that Ferhán had left it, and was with his son Mijuél, a day's journey further still. Ismail came up just as they told us this, and saw that the game was up; so, when the men had ridden away with their camels, he came to us and said, with a rather ghastly smile, that he must wish us good-bye here. He had to be at Naif's tent before night, and, if we would not come with him, why he must leave us to our fate. He couldn't go with us further north. He and Faris's people were not friends. We replied, "So be it," gave him a polite message to his master, and, to his great joy and surprise, a present for himself. We had gained our point, and could afford to be generous. So he wished us good-bye and various blessings between his teeth. Then, putting his kadísh into a feeble canter, he departed.

Circumstances had favoured us, for Daëssan was behind and the rest of our caravan out of sight, so that no discussion with any of our people had been possible, and when we returned we had only to announce Ismaïl's departure as a fait accompli. Daëssan, finding himself relieved from the burden of Ismail's presence, now made no objection to giving us the true direction, and the camels' heads 
were turned north-west, while our followers, after a few expressions of disappointmont, lapsed into silence. We travelled on thus for two hours, regaining most of our lost ground. Wilfrid was then fortunate enough to discover a pool of rain water, the first fresh water we had met with since leaving $\mathrm{El} \mathrm{Haddr,} \mathrm{and} \mathrm{there} \mathrm{we} \mathrm{filled} \mathrm{our} \mathrm{goat}$ skins. We should have liked to encamp beside the precious element, but Daëssan, saying that seriously there was danger in the country we were entcring, begged us to go a little further on. We are now encamped in a wady, far away from all living creatures, and nicely hidden from the surrounding plain. Ali, Hánna and the rest are very serious and quiet this evening, and we hope to have an undisturbed night, having had troubles enough during the day.

We are now in the heart of Mesopotamia (just at the top of the second $O$ in our map). The tents have not yet been pitched, for fear of distant eyes - for this is neutral ground, between Ferhán's people and Faris's, where nobody comes for any good.

March 12.-Ali, who had hitherto supported us loyally in all our plans, came last night to our tent, and sitting down, explained that he considered it his duty to warn us against persisting in our journey any further in the direction we were taking. He was convinced that we were going into an uninhabited region, from which we should find no exit, 


\section{Bedouin Tribes of the Euphrates. [сн. xir.}

and quite in an opposite direction to that which we intended. He remarked, as was perfectly true, that Daëssan was blind, and could not be expected to make a very efficient guide, and that we had only a couple of goat skins with us, and seven people to supply with water, to say nothing of the four horses and the donkey. We had great difficulty in pacifying him, for, in truth, we were a little anxious ourselves; but we got out the map and showed him our position on it and that of the Khábur, which could not now be more than eighty miles off, as, in spite of our loss of ground yesterday, we have been making long marches. He was not convinced, but did not insist with his objections, and I am sure we can depend upon him.

Daëssan, too, was rather gloomy this morning, for the twisting and turning about yesterday had put him out of his reckoning, and he is so blind that he had not been able to see the Tell Melífeh, and had lost his bearings. He was nervous too about enemies, and constantly beggged us to keep a good look-out for khayál. However, we saw nothing but some bustards and a fox. Wilfrid and I rode in front giving the direction, and he followed a little behind, so that the camel division might not lose sight of us. The country now was no longer flat, but rose rapidly before us, and after an hour or two we came to a high position, from which, to our great delight, we could see hills to the north, which we knew must be Jebel Sinjár; while below us, to our left, an 
CH. XIV.

immense lake appeared with some high cliffs beyond it. Here we dismounted and waited for the rest to come up. Daëssan, though he could not see these things, recognised our description of them, confirmed us in our recognition of the Jebel Sinjár, and gave the lake a name, Snéyseleh. He told us we should have to go some way further in order to get round the head of it, and asked us anxiously if we could see no tents.

After a careful examination of the ground beyond the lake, Wilfrid, who is long-sighted, made out some black specks on a sort of plateau, with some lighter specks around them, which by careful watching were seen to move, and he pronounced them to be tents and camels. The encampment appeared to be about six miles off, and we agreed at once to go towards it. It lay to the west. First, however, there was the súbblha to be circumvented, and we were obliged to alter our course northwards and skirt its shore, looking for a place where we could cross, for the upper part of the lake was evidently quite shallow, though about three miles in width. At last we came to the track of a camel leading across the wet mud, which we could trace for a long distance till it disappeared in the mirage, and Wilfrid, impatient to go straight to the tents, determined to follow it, while Daëssan and the rest of the party should go round the head of the lake. I foolishly went with him, and doubting the soundness of the bottom did so on foot, but I had 
304 Bedouin Tribes of the Euphrates. [cr. xiv.

not got more than a few hundred yards before I was quite exhausted, and my boots and skirt were so clogged with mud that I was unable to get any further. I confess that I was rather frightened, for already there was such a dense mirage that we could not see anything round us but the uniform expanse of mud, and we had left the camel track, which meandered about, and I thought we were going to end our days in this miserable place. But Wilfrid would not turn back, and at last I managed to scramble on to my mare, and then found matters less hopeless, for the mud was not really much over her fetlocks, and did not get any worse. Also from the higher position I could see better, and make out the form of the opposite hills wavering through the mirage. So we struggled on for an hour and a half, and at last landed safely on the other side.

As we got to higher ground, we looked back across the súbblha for the camels, but they were nowhere visible, being far away, rounding the head of the lake; but about half a mile in front we saw a man standing, and rode up to him. He had been watching, no doubt, for a long time, and asked us why we had come across the lake instead of going round. He told us, too, after the usual evasive answers Bedouins always begin with, that the tents of his people were those that we had seen from the other side, and expressed surprise that we had been able to count them from so great a distance. As soon as he heard that we were not marauders, but travellers 
on our way to Faris, he became very amiable, and we all three sat down, while our mares grazed, waiting for the camels to appear. This they soon afterwards did, to our no small relief. The man told us he was a Gáët (one of the Shammar tribes), and that his Sheykh, Béddr, was five or six hours further on; that Béddr was a friend of Faris, and that Faris himself was at a place called Sheddádi, on the Khábur, only a day's journey beyond Béddr's camp. This was indeed good news; and great was the rejoicing in our party when they at last came up and heard it.

The man, who was a good-humoured honest fellow, now put us on our road, pointing to a line of hills, from which he declared we should see Béddr's camp. The ground rose rapidly from the lake, and we travelled up an irregular incline for another two hours, passing a nice pool of rainwater covered with ducks, where we watered our mares. The whole ascent above the súbblkha must be two hundred and fifty or three hundred feet; and the line of hills, as generally happens, turned out to be the edge of an upper table-land, from which a really magnificent view southward is obtained, with the súbblkha like a sheet of gold in the middle of the lower plain. Beyond we could still see the Melifeh hill, with its flat top, a very prominent landmark. Northwards and westwards the upper plain also sloped away, an even expanse of down, and about twenty miles off ran the line of 
306 Bedouin Tribes of the Euphrates. [cн. xiv.

the Sinjár hills, and of Jebel Abdul Aziz, which is a continuation of them westwards. We looked in vain, however, for any tents. For ourselves we should have been quite content to stop where we were, having water with us and grass, but Daëssan and the others were in a feverish state of anxiety to get on and sleep at a camp to-night, and again the talk turned on ghazús and other "moving accidents," so that we consented to continue, though it was growing late. We made for a little tell about two miles off, and from it we at last saw tents, but far away to the north. There the camels waited with me while Wilfrid galloped on to a yet further tell, from which he was to signal us by moving to the right or left, or standing still or coming back towards us. He stood still, and we knew by that that he had seen something and that we were to come on. A camp had been discovered, and not more than two miles off.

We are now enjoying the hospitality (if enjoyment it can be called) of one Sayah, Sheykh of a fraction of the Sabit Shammar, a silly old man, with an enormous family of rather ill-bred children, who bores us to extinction. However, he has killed a lamb for us and brought dates and butter, and promises to take us to Sheddádi no later than to-morrow, and our dangers and difficulties at last are over. Yet I regret the calm of the desert in this noisy dog-ridden camp.

March 13.-Sayah's hospitality was after all not 
of the purest kind, for it turns out that he made Hánna give him a mejídie for the lamb last night, and then ate up nearly all of it himself. Our own share consisted of the liver, the heart, and the great fat tail, none of which we could eat. Moreover, his wife borrowed our cooking-pots for the feast, and troubled us with her company after it. But these are things one has to put up with without remark.

In the night there was a hard frost, and some water I poured into a tin cup at six o'clock this morning had ice on it at seven, a difference of climate since yesterday which may in part be accounted for by the extra three hundred feet we have climbed. We left Wady Adíg, for such is the name of the little valley where we found the Sabit camp, at half-past seven, and expected to reach Faris's tents this evening; but Sayah, who volunteered to be our guide, has led us such a roundabout dance all the morning that now, after nine hours and a half of hard marching, we have been obliged to stop.

Of all weariful old geese I think I never met Sayah's equal. When we asked him the direction at starting, he answered in the tone of one putting off the foolish questions of a child, "Never mind (my dears); if you have a little patience, you will soon see. I, Sayah, you understand, I" (pointing to his chest) "will show you the road, and, please God, we shall be with Faris before noon." So off 
308 Bedouin Tribes of the Euphrates. [сн. XIv.

he started due north, and then half an hour afterwards took a turn due west, and then north-west, and then stopped a little to consult with Daëssan, and then appealed to us (for he too is short-sighted), to say whether we could see no tents.

"Whose tents?" we asked.

"Oh, any tents would do. Our object was to go to Faris; and we must find out where Faris: was."

The sun had begun to warm the ground, and there was a strong mirage, so that for a long time we could see nothing further than a few hundred yards any way, and we began to suggest that a straight line might be the shortest way of arriving. somewhere, if not at Sheddádi. But Sayah explained sententiously that we were now travelling "in the desert, which was not at all the same thing as travelling in a town, and that we could not be expected to know the way about as he did. He was a Bedouin, and was used to the desert from. youth upwards. We should soon find some tents, please God, where we should learn the road." We wandered on in zigzags all the morning, and at last, coming to some higher ground, where there were graves, discovered a large encampment of forty or fifty tents, far away to our right under the Sinjár hills. This range is rery beautiful, and not further off now than twelve or fifteen miles, so that we can see or fancy we see patches. of green trees and gardens at the foot of the slopes. 
Sayah tells us there are fifteen villages in different parts of the range, inhabited by a Kurdish race called Zedíchs, * worshippers of Satan, who cultivate gardens of figs, grapes, and pomegranates, and wear black turbans on their heads.

Sayah wanted of course to go to these tents, but we knew they must be far out of our way, if Faris was on the Khábur, and insisted on waiting till something more nearly in our proper direction should be sighted. Presently we came across a large party of Bedouins in marching order, moving camp. It was a pretty sight. First of all came a dozen horsemen with lances; then in a straggling line some sixty baggage camels, some carrying tents and pots and pans, others great hóvelatis full of women and children; then boys and young men on foot driving donkeys and surrounded by camp dogs, with here and there a greyhound; and lastly herds of milch camels and flocks of sheep. They were marching from north-cast to south-west, and so crossed our line at right angles. They informed us that Faris had left Sheddádi and was gone down the Khábur. The tents we had seen to the north were Béddr's. They said there were some 'Taï $†$ nearly west of us, and to them we resolved to go Daëssan informing us that Faris's mother was from these people, and that their Sheykh's name is Abd er Ráhman, and that they number a thousand tents.

* Yezilis; described by Layard and others.

$+\Lambda$ "noble" tribe tributary to the Shammar. 


\section{Bedouin Tribes of the Euphrates. [cr. xiv.}

At half-past twelve we crossed a track said to go from Nisibin to Melkh Ubuára, where the salt is, Nisibin being three days' journey from here.

Soon after one o'clock Wilfrid and Sayah galloped on to get information at the Taï tents, which we perceived a long way off. Sayah is well mounted on a Seglawíd Arjébi, a powerful bay with a good head, but I and my mare were tired and we lagged behind sadly. When they got within three miles of the Taï camp, Wilfrid stopped for me and sent on Sayah alone for information, but, considering on refiection that the old man if left to his own devices would be unlikely to appear again to-day, he galloped on again after giving me instructions what to do with the camels when they should come up. It was beautiful to see Hagar, after all these days of hard travelling, doing these three miles at almost racing speed, for in her anxiety to rejoin Sayah's mare she went off like an arrow. The ground sloped gradually down towards the Taï camp, and I could watch her progress all the way. After I had waited alone for nearly an hour the camels came up, and we went on to a little hill in our line, which we had agreed should be our rendezvous. He joined us there soon afterwards, and said that he had had great difficulty in getting away from the hospitality of the Sheykh Hamid, a venerable old man who appeared to be very rich. His tent was the largest and best furnished Wilfrid had yet seen, not excepting Ferhán's at sherghát. The news. 
learnt there was that Faris, who is this Hamid's nephew, moved down the Khábur in the direction of Deyr this very morning and is not far offbut we have lost so much ground to-day, that we have stopped at the first good camping place we could find after leaving the Taï. It is to my mind a perfect camp, a hollow in a rather high down commanding a splendid view of the Sinjár hills. We have been cutting bundles of green stuff for our mares to eat at night, for the corn has been finished some days. It is a beautiful evening, the moon just entering her second quarter, so that the camels will be able to feed half the night, - an evening which well repays the hours of weariness during the day, and even the miseries of last night's camp among the Sabit dogs and the Sabit women who so pestered us by peeping into our tent. 


\section{CHAPTER XV.}

"'Now therefore swear unto me here by God that thou wilt not deal falsely with me, nor with my son, nor with my son's son: but, according to the kindness that I have done unto thee, thou shalt do unto me, and to the land wherein thou hast sojourned.'

"And Abraham said 'I will swear." "-Gressis.

A gentleman of the desert and his mother, the Hatoun Amsheh -Well-behaved boys-Tellál-Faris goes out shooting-He swims the river-Swearing brotherhood-Rashid ibn Ali and the Sheykh of Samuga-The Yezidis-A raft on the KháburCamels swimming-Farewell to Faris-A gallop in to Deyr.

March 14.-We are with Faris. I write it with some pride, when I think how many "impossibilities" once stood in our way, and how doubtful success seemed even so lately as three days agoyet in point of fact there has been neither difficulty nor danger to encounter. Only a little obstinacy was wanted; and here we are.

At early dawn on the day of our arrival we sent out Sayah, like the raven from the ark, to see what tidings he could bring of the Shammar chief's camp. He came back sooner than we expected, in less than three hours, and announced success from a distance at the top of his voice as he approached us. "Faris was close at hand; he had seen him; he had spoken to him." "Shil, shil" (load up, load up); "we 


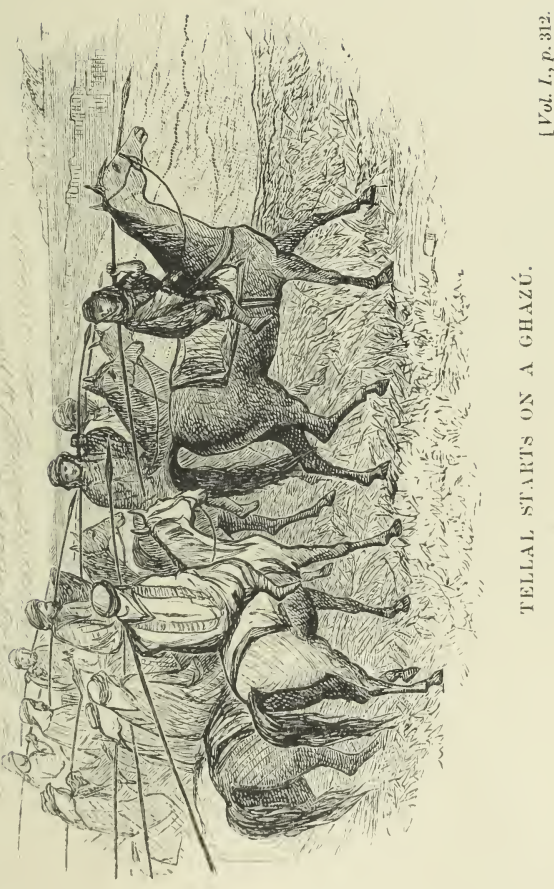

i

$\dot{c}$

$\stackrel{3}{5}$

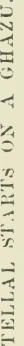



shall be there in an hour." Such was the joyful news; and though, like most Bedouin statements, this one hardly bore out its first promise, for Sayah had not really cither secn or spoken to the Sheykh, having only met a shepherd belonging to his establishment, yet it was little past noon when we rode into the camp we had looked for so long. The first tent indeed would have been visible from the top of the down, not half an hour's ride from where we stopped, if we had gone to look for it last night.

The tents of Faris's people are scattered down a long meandering wady perhaps a mile in length, and at noon, the time of our arrival, had not a very animated appearance. The sheep and most of the camcls were away at pasture, and only the mares remained near the tents. The wady was white as snow with camomile in full flower, the favourite food of camels, and on this account no doubt the spot had been chosen. The mares we passed were not particularly attractive-raw-boned, half-starved creatures with their winter coats still on them. But the Shammar have, I fancy, but few fine horses in spite of Sayah's tales of Faris's stud, " each beast worth a thousand pounds." More attractive were the new-born camels which every here and there peeped out of the herbage, creatures all logs and neck, which when squatting close may well be taken for gigantic birds, so little heads they have and such immense eyes.

At a bend of the wady we came suddenly on a 


\section{I4 Bedouin Tribes of the Euphrates. [cr. xv.}

great tent, with seren peaks, which we knew by its size must be the Sheykh's. It was standing with a dozen others just where the valley broadened out into the plain, and as we rode up to it unannounced, we began for the first time to feel a little anxious about the reception we might meet with at the hands of the man we had come so far to see. But we need not hare doubted. As soon as we were perceived, servants came out to meet us and hold our horses, while all those present in the tent stood up and answerec our salutation in a friendly voice. Faris himself, a young man of most attractire countenance, appeared from the inner tent and greeted us with a smile that had so much honesty in it and good will that we felt at once that we were safe in his hands. He bade us sit down, and made us comfortable with rugs and cushions, and sat himself beside us and listened to our compliments and returned them gracefully and with the ease of perfect good-breeding. He inquired most amiably about our adrentures since we left Deyr, for he had heard of our arrival there and eren of our attempt to pay him a visit last month. He said he had been long expecting us, and now we must stay with him: his tent was our tent, his people our people, and, though these and other phrases are more or less conventional in the East, he put a tone of so much sincerity into the words that they really touched us. His manner is quite different to that of any one we have hitherto met 
in the desert, for it is frank and cordial, as if its owner was sure enough of his orn position to be able to do without the stiffness and false dignity most of the Bedouins affect when they are with strangers. Indeed a better bred man it would be difficult to find. Such are our first impressions, and I write them down while they are fresh. I think we have at last found that thing we have been looking for, but hardly hoped to get a sight of, a gentleman of the desert.

But I am tired and must put off further description till to-morrow, for we are to stay here now some days.

* * * * * * * * *

March 16.-(I must condense what I have written during the last two days; for my journal has become a mere mass of notes, for the most part taken from conversations we have had with various interesting people here, and requires re-writing.)

By far the most important personage in Faris's camp, the young Sheykh himself not excepted, is his mother, the Hatoun Amsheh", better known in the tribe as the "Mother of Abd-ul-Kerim." I think it pretty and touching that they should retain this title for her instead of calling her the Mother of Faris, the rising sun among them, and that they should thus do honour to the dead brother instead of to him. But the fact is, Abd-ul-Kerim was a

* Compare Layard's account of her as a young woman in 1843. 
3 I6 Bedouin Tribes of the Euphrates. [сн. хv.

hero whose name will linger for many generations yet among the Shammar, as that of their greatest man. During his lifetime the tribe was rich and powerful, and enjoyed a prestige in the desert such as it is hardly likely ever to have again; for the unity of the Shammar is broken, and, divided, they never can contend on equal terms with their great enemies the Ánazeh. That he was a real hero of romance it is not difficult to see; for his memory pervades the whole life of the family and tribe he has left behind him, and is the motive of three parts of the loyalty with. which the present Sheykh is honoured. The mother of Abr-ul-Kerim is a sort of holy personage, and object of veneration, with all the tribes of Northern Mesopotamia. She was, as I have already mentioned, a Taï by birth, and sister of the Sheykh Hámid, whom Wilfrid made acquaintance with the day before our arrival; and she must have been formerly very beautiful. The Tai have the reputation of being the handsomest women in the desert. She is now old and fat (fat, alas! is the tomb of beauty); but in spite of infirmities she is a most dignified personage, and her will is law in all the camp. To-day Faris, like the spoilt boy that he sometimes is, amused himself with firing off Wilfrid's rifle close to the tent, and at last took aim at some goats belonging to a neighbour. The old lady very properly thought this undignified behaviour in the Sheykh, and sent to tell him so, and he put down the rifle at once 
without a word. In Faris's tent she reigns supreme, allowing no other woman to share her power over him. Even his present wife, a slave from the Taï, lives in another tent. His first wife was a woman of good birth, but she is dead; and there is one son by her, a pretty boy of nine, named Salfij, who is brought up by the Hatoun, along with Abd-ulKerim's son, Mohammed, and his daughter, Menífeh, ten and thirteen years old, and a charming boy of twelve, Tellál, the son of another brother, Abd-urRaják, also dead.* Both these boys are made more account of in the tent than Faris's own sons, because they are orphans. They are all exceedingly well brought up, and have charming manners, besides being as straightforward, courageous boys as you could possibly find in any part of the world.

I never saw a prettier sight than Tellál on his chestnut mare, the day after our arrival, armed. with a lance three times his own length, doing the fantasia with his uncle and a score of devoted retainers, who, while they admired the boy's courage, seemed terribly afraid he should get hurt; and all the time the boy himself thought nothing, I am sure, of danger, either to himself or to anyone else, in the sport of pursuing and of being pursued, with the steel point of a lance within six inches of his back. He would gallop up to his uncle, as he was riding beside us (for we were all marching in line,

* He was shot by the Turks at the same time that his brother, Abd-ul-Kerim, was captured. 
moving camp) and challenge him, according to Bedouin practice, by pretending to attack us, and then shoot away like an arrow, with Faris, who is a magnificent horseman, thundering close behind, and making his lance quiver over his head, and then twist and turn and double till he managed, thanks to his feather weight, to escape. He often comes to our tent to look at the guns, and knives, and strange European knick-knacks we have with us, and talks as sensibly as an English schoolboy about his amusements and what he is going to do when he grows up, and in just the same frank, outspoken way. He was looking to-day at Wilfrid's dress-sword, a merely ornamental piece of goods, given him by Mr. S. to wear on state occasions, and which Tellál was at first inclined to admire from its being covered with gilding and having a handsome belt; but, having drawn it, and very cautiously felt its edge, and found it as blunt as sword could be, his face put on an expression of unutterable disgust, and he threw it down,- "It isn't fit for the Beg to wear," he said; "feel mine;" and he showed us an old blade as sharp as a razor in a very shabby sheath, which had belonged to his father. Wilfrid has taken a great fancy to him.

Mohammed, too, is a nice boy, but shy, which Tellál is not, and, being some years younger, only rides a pony; while Salfij is still in the nursery. All three boys are, of course, the delight of every 
Arab in the camp; for the men here are goodnatured to children, and these are the children of their Sheykhs.

Among the Shammar there is a strong feeling of loyalty towards what may be called the royal family. It was Faris's ancestor, Faris, who led the Shammar from Nejd at the time of the Conquest, two hundred years ago, and no pretender from any other family has dared to claim the position of Sheykh, to the prejudice of his descendants, since.* These children, therefore, have a double title to the people's regard, as sons of their heroes, and as sole

* The following is Faris's genealogy, which he gave us to-day, correcting it now and then by an appeal to the elder men about him :

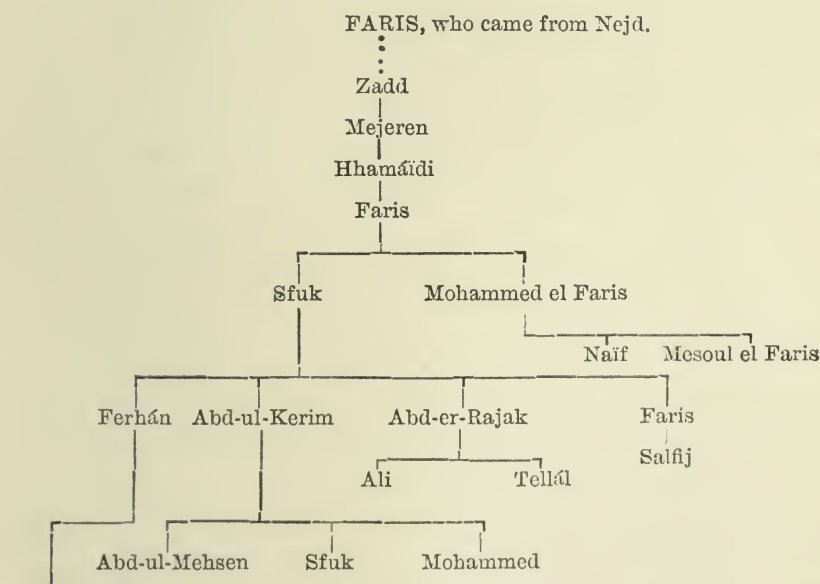

Eyssa Mijuel Jarrulla Muttakh 
representatives, with the present Sheykh, of the family of their chiefs. That Abd-ul-Kerim, the scion of such a family, and their Sheykh and their hero, should have been seized by the Turks and hanged as a common robber on the bridge of Mósul, makes every Shammar's blood boil. Ferhán is not reckoned as legitimate by the independent Shammar, and is despised even by his own followers in the south, because he is the son of a Bagdad woman, "not a Bedouin at all-a mere felláh, a ráyah." Faris's accent of disgust, while using these words of his half-brother, is very amusing. And Ferhán's sons are worse, tainted over and above with Kurdish blood-_"real Kadíshes."

Faris himself has justified all our first impressions in his favour. He is frank, goodnatured, and agreeable; and he and Wilfrid have become the greatest possible friends. From the very outset he took us into his confidence, explaining his relations with Ferhán and with the Turkish Government, and treating us as if convinced of our loyalty and goodwill. His account of the desert politics, in which he is beginning to play a conspicuous part, has especially interested us. I have already mentioned the tragical death of his two brothers, Abd-ul-Kerim and Abd-ur-Raják, and his mother's flight to Nejd, and their sojourn there. On his return, three years ago, he found Ferhán acknowledged by the Shammar as their Sheykh, and the whole tribe in danger of becoming perverted from 


\section{cн. хv.] Domestic Broils of the Ibn Sfikes. 32 I}

their ancient way of nomadic life by this "Bagdadi," who had accepted the rank of Pasha from those very Turks who had hanged his brother, and who, in consideration of a yearly allowance, had agreed to make his people cultivators of the soil, "mere ráyah, and felláhin." This the more high-spirited of the Shammar have deeply resented, and Faris no sooner appeared among them, recalling by his presence the memory of the chief they had lost, than he was joined by nearly half the tribe, and by all those discontented with the new order of things. Ferhán, who cares more for his position at Bagdad than for his real influence in the desert, and conscious, perhaps, of his own inferiority in birth to his young half-brother, has not hitherto made any vigorous attempt to control him; but Faris com plains bitterly of the machinations of the Pasha's sons, Eyssa and Mijuel, who are constantly attempting to involve him with the Turkish authorities, by making raids on the felláhin tribes of the Euphrates and throwing the blame upon Faris's people. 'Though not exactly at war, he and these sons of Ferhán have once or twice come to blows, and on one occasion Mijuel was wounded by his uncle's lance. Their people are not on speaking terms, and the uninhabited region we have just crossed is left by both sides as a neutral zone between tho northern and southern camps.

The very day of our arrival, Faris informed us that he should be obliged to sacrifice the pleasure vol. I. 
of our society to the necessity of heading an expedition against his nephews, for they had attacked a merchant of Mósul, travelling under his safe conduct, and had taken sheep and camels from him. There was a great bustle in the camp; horsemen arriving from all points of the compass to have their mares shod, in anticipation of the ghazú, for the only blacksmith among them lives in the Sheykh's tent. But in the morning a messenger arrived to say that all the stolen beasts had been recovered, and Mijuel driven back to his own country; so Faris has remained with us.

As to his relations with the Turkish Government, he has been equally communicative. From the time of his brother's death he had not entered a town or trusted himself in the power of any Turk until a month ago, when our old friend, Huseyn Pasha, acting, I suppose, upon the advice we had given him, sent him a polite invitation to come to Deyr, offering him at the same time Gorernment pay and support if he would help the Turkish authorities to keep order in Mesopotamia. Faris, being a young man and perhaps a little dazzled at this token of consideration on the part of the Government (for influence "in the town" has a wonderful attraction to the Bedouin mind), went to Deyr, and was received there with all possible honour by the Pasha, who, to do him justice, is a man of great tact and discernment, and, being of Syrian not Turkish birth, has a certain sympathy 
with the people of his district. There it was agreed between them that Faris should keep order in the desert, in consideration of a certain sum of money, to be paid monthly - a not uncommon arrangement, -and that he should receive Huseyn's support and countenance in his quarrel with Ferhán's sons.

We are rather sorry to hear of this ; for, though in theory it would no doubt be an excellent plan for keeping the peace, yet in practice we know that little good ever comes of such arrangements to the Bedouins, and that the less they have to do with pashas and governors, the more easy it is for them to retain their independence. Faris, besides, is too straightforward and simple-minded to engage in diplomacy with Huseyn, and he ought never to put himself into the hands of the official enemy of his house. Huseyn, though with the best private intentions, may find himself any day ordered to arrest the brother of Abd-ul-Kerim, and Faris's position as a guest at the Serai will be no protection to him then. We are glad to see that the elder men of the tribe, who look upon him with as much affection as if he were their own son, are quite of this opinion; and they were delighted when we explained to Faris how dangerous it was for him to go to Deyr. "Has he not his house here," they say, "and his people and his friends, that he must look for them in the town? He should remember the fate of Ibn Mershid." And after all Huseyn's protestations, it appears that the promised money 
has not been paid, insignificant as the sum is, and that Faris's work as zaptieh has been done balásh, gratis. But the Bedouins are like children in their love of silver pieces, and will pursue the prospect of touching a few mejidies like an ignis fatuus far beyond what its worth really is to them. I am sure if Huseyn had offered him a thousand sheep, Faris would not have gone out of his way for them; but the hundred Turkish pounds is quite a different thing, and has just such a magical effect as the fourpenny piece which children claim for having a tooth out. He would not keep the money, probably, if he got it, for a single day, but would distribute it to those about him as he distributed our cloaks and boots; but it would be a vast pleasure to him to think that he had had such a sum in his hands. Wilfrid has given him a deal of gond advice on these matters, all of which he takes in the best possible spirit. "You are my father," he says, " and know better than I." It is impossible not to be fond of so charming a character.

In person Faris is small, as a true Bedouin should be; but he is a model of grace and strength and activity. On horseback there is no one in the tribe who can come near him; and it is a fine sight to see him put his mare to her full speed, and make his lance quiver over his head till it almost bends double; and it is easy then to understand, what his people say of him, that his presence on a ghazú is worth thirty horsemen. He is besides very good- 
looking, with features typically Arabian, a clear olive complexion not darker than that of a Spaniard, an aquiline nose, black eyebrows meeting almost across his forehead, and eyes fringed all round with long black lashes. His smile is one of the most attractive one can see; and, if there is a fault in his face, it is a slight want of resolution in the shape of his under jaw, which makes one fear for him some tragical ending like his brothers', brought on by his own waywardness. He is twenty-seven years old, but looks younger, and every now and then seems subject to fits of boyishness which appear unsuitable to his position, though he can assume the greatest possible dignity on occasion. In his manner towards his people he is especially happy-respectful to the old men, who spoil him, and unpretending with his equals, among whom his personal qualities give him so much ascendancy that he can afford to be familiar without losing any dignity. His people are evidently devoted to him, soul and body, and proud of him as the handsomest man and the best rider in Mesopotamia.

On the 15th, the day after our arrival, the ghazú having been abandoned, we all marched together to fresh camping-ground on the banks of the Khábur, where just now there is abundance of grass and camomile for sheep and mares and camels. It was on this occasion that the fantasia I have mentioned was executed in our honour, and that Tellál made so capital a figure on his chestnut mare. Faris's 
own mare is a tall bay, Shuéymeh Sbáh, with a powerful shoulder, great girth, legs like iron, but a rather coarse hind quarter. She is not goodlooking. Indeed, we have not seen above three good-looking mares in the whole of our journey through Mesopotamia, the only really handsome one being a grey Saadeh belonging to one of Faris's men, four years old, and standing about fifteen hands. I do not, however, see any trace of mixed blood in the Shammar horses, as some people maintain there is. The mares look thoroughbred enough, if the head be an index, but they are defective in shape and beauty. The great strains of blood are among the Shammar.

In the afternoon Wilfrid took the Sheykh out alone shooting, as he wished to see how birds were killed flying; and he showed a childish pleasure in the firing of gun and rifle, aiming sometimes with the greatest precision at a crow a hundred yards off with snipe-shot, and at others playfully letting off a ball at a wagtail perched on a twig of tamarisk close before him. It was dangerous work, but fortunately no accident happened. Wilfrid shot a francolin, which fell in the river, and Faris in an instant had stripped and jumped in. The Khábur is deep and strong, and has steep, muddy banks, so that Wilfrid had some difficulty in getting his friend out again, especially as the water was very cold. But Faris was delighted, and came back in triumph with the bird. It was amusing to see this powerful Sheykh, 
whose word is law in half Mesopotamia, excited like a child with the adventure. But I like him all the better for it.

This little episode, and the help Wilfrid had afforded in getting him out of the river, has made them such fast friends, that this evening, while we were sitting talking in our tent about his early troubles, and his hopes and prospects, and the pleasure our visit is giving him, he said that now he and Wilfrid must be as brothers, "to-day and tomorrow and hereafter," to which Wilfrid willingly responded, for we both of us feel a real affection for him, and his friendship for us has been quite of spontaneous growth; and so without more ado it was agreed that they should take the oath of brotherhood. Wilfrid told him how he was alone in the world without brothers living, just as Faris was, and with few relations that were much more good comfort to him than Ferhán and his sons were to Faris, and he declared that now, inshallah, he and Faris should be brothers for the rest of their lives. Then they took hold of each other by the girdle with their left hands, and, holding their right hands up as appealing to heaven, they repeated the prescribed form of words very seriously, for this is a pledge no Bedouin ever takes lightly. Faris began: "Walláh! Wallahí!" (O, God! O, my God!), and Wilfrid repeated after him, "Walláh! Wallahí! Walláh! Walláhí!" each perhaps twenty times; then "Billáh! Billahí!" (by God, by my God), "Tilláh! 
Tillahí!" (through God, through my God); "akhwan, akhwan, el yom u bokra o baadén, akhwan," (brothers to-day, to-morrow, and hereafter)-an oath as impressive as those of our marriage service, and considered quite as binding by those who take it. This pledge of brotherhood, once taken, cannot be dissolved. It binds the swearers to be henceforth brothers, as though born of the same mother, in all things, except that it is no bar to marriage of the one with the near relations of the other. Personal combat is henceforth not allowed, even if the tribes of the two brothers should afterwards be at war; nor can the property of a brother be seized by a brother or by any of his people. The swearers have, on the contrary, a right to aid and assistance in case of need; and a brother, if called upon, is bound to avenge his brother's quarrel.

There was something so impressive in the ceremony that, for some minutes after it was over, we all three sat without speaking, till Faris, seeming to recollect that something more was necessary, got up and, calling to his mollah, or secretary, who was in the other tent, to come, made him attest the validity of the act by stating to him what had happened. Two witnesses, he informs us, are necessary to make the oath binding; but it is considered sufficient that the second witness should be informed of the fact on the day on which it takes place. The mollah put his hand to his head, and said gravely: "The Beg is now one of our people ; let him come into our tent." 
He went on to tell the news to the rest of the Sheykh's household, and, when Wilfrid entered, they all stood up, and the eldest made him a little speech to the effect that this tent and all the Shammar tents were his, and their camels and sheep and all that they had; and Faris said, "You must stay with us. Our people shall make you tents like their own, and I will give you camels, and you shall live with us instead of going away to your own country." Wilfrid tells me, and I can well believe it, that he was much affected by all this, and that, come what may, he shall always hold Faris truly as his brother, though he may never be able, or be called upon, to prove it.

March 17.-Our relations with the Shammar are now on a quite different footing from heretofore. Before it they were polite and friendly, but now we are shown what is very like affection. The Hatoun Amsheh sent for me and kisserl me, and said that she was now my mother, and that if we were ever in any difficulty, inshallah, her son should help us. I am sure these are not mere empty words. Faris, too, who has up to this refused all our invitations to eat or drink with us in our own tent, we being his guests, and who has always sat at the door instead of coming inside, has now sent a message through Hánna to " his brother," to say that he will dine with us. So we have produced our best curry and búrghul and sweetmeats, and made him sit between us, and poured a whole tin of sugar into his coffee, the thing of all others which he likes 
best ; for the Bedouins, who have none of their own, have a craving for sugar. The dinner has been so successful, that now he says he will take his meals nowhere else, and I am afraid will find it difficult, when we are gone, to go back to the coarse Arab fare of his own tent. I hope Faris will remember his brother and sister as long as we intend to remember him.

Besides the Sheykh's household, there are two most interesting persons, guests of the Shammar. The first is Rashid ibn Ali (mentioned by Palgrave as the only member of the old reigning family of the Sheykhs of Jebel Shammar which escaped the general massacre of the "Beyt Alec," on the conquest of that country by Ibn Saoud). He is a man of fifty-five or sixty, of rather dark complexion, and much muffled up about the face, but of an ordinary Arab type of countenance, and undistinguishable in dress or manner from the other Bedouins here. On better acquaintance, one perceives that he is a wellbred man. He was pointed out to us originally as a man of distinction, by our little old guide Daëssan, who knew what an interest we take in Nejd and in Jebel Shammar, and who informed us that Ibn Rashid had killed fourteen of his relations. We have accordingly made his acquaintance, and have got from him a deal of interesting information. Wilfrid has cross-questioned him narrowly on the subject of Nejd horses, and he confirms everything that has alrearly been told us by Smeyr and Daëssan, 
stating most positively that there is no Nejd breed of horses, ever heard of at Hîyel, nor any horses at all in central Arabia but the horses of the Bedouins, whose breeds are well-known and everywhere the same. He says that no horses are bred in the neighbourhood of Riád, which is a country without pasture, and that in other parts of Nejd the specimens are smaller, and in no way better than the Anazeh horses. He repeats that Ibn Rashid gets all his mares from the Bedouins, mostly from the Ánazeh, and adds that Ibn Saoud gets what horses he has from Ibn Rashid; but the present Imam is not as rich as his father Féysul was, and has not in fact many horses, while nobody else at Riád has any at all. The best horses in Arabia are the horses of the Ánazeh-especially the Sebáa and the Fedáan.

With regard to Jebel Shammar, Rashid says that the hills there are higher than the Sinjár; but he does not talk of snow on them. Hîyel has a thousand houses, walled houses, beyut haggar (he pronounces his g's hard, as in Egypt); but outside in the Gebel there are twenty thousand tents, a few of them only Shammar. Ibn Rashid himself is a Shammar. One or two Franks have been to Hîyel, one last year; but Ibn Rashid had not received them. He assures us that there would be no danger to any one going to Jebel Shammar, but that Ibn Rashid dislikes foreigners, and will have nothing to say to them. If we wish to go there, he will go with us. $\mathrm{He}$ is returning in a month's 


\section{Bedouin Tribes of the Euphrates. [сн. xv.}

time, and we should stay with him at Hîyel as long as we liked. $\mathrm{He}$ is going the way he came, and that is by Húseyn (Meshid Ali). This is an itinerary of the route he has given us, which may be worth transcribing :

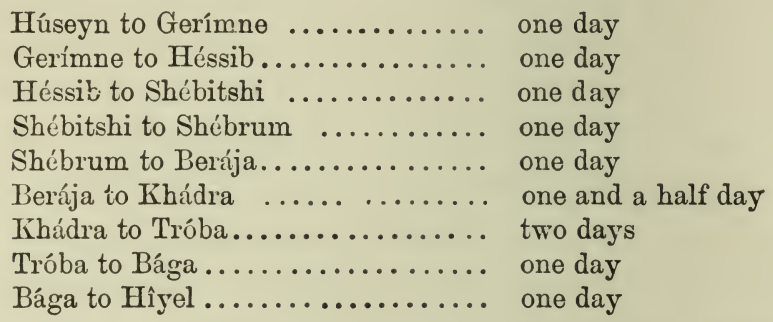

The three principal Bedouin tribes of Jebel Shammar are the Duébi, the Ibn Heyt, and the Firrme; west of it are the Sherarát.

I should like to be able to accept Rashid Ibn Ali's invitation to Hîyel, but we are not professional travellers, and a summer in Central Arabia cannot be thought of.

The other person of interest staying here is Mátu, Sheykh of Samúga, the principal village of the Jebel Sinjár, and, of course, a Zedíyeh. He is here on business with Faris, connected with a quarrel he has with the village of Sekinieh, and I fancy he wants Faris to help him. He is a Kurd, and is quite different in features from the Arabs, and has besides certain peculiarities of dress, the chief being the black head-dress of which we had heard. He also makes us take notice that his shirt 
is cut square at the neck instead of being round; and this, too, we had heard of as a remarkable point of distinction between the Zedíyehs and the Arabs, made almost as much of by the latter as the belief that the Zedíyeh worship the devil instead of God,-for fashions in dress are more unalterable than those in religion. He has told us a good deal about his religion-more, I am sorry to say, than we are quite able to understand. He denies, of course, the worship of Shaictán. According to his account, the Zedíyehs believe in one God and one great prophet, with several lesser ones. They all acknowledge Huseyn Beg,* chief of one of their tribes north of the Sinjár, as the supreme head of their religion. Mátu's words were, "Melek ed Taous, our prophet, is to us as Eyssa is to you, and Huseyn Beg is to us as your Pope is to you." He says that they have two religious books, that of Zabú, or Daoud, and that of Enjír or Eyssa, the former accepted by all Zedíyehs, the latter only by a few, who have it in addition to the first. He adds that they do homage to or worship the sun, "like the Parsees." They have no restriction as to the number of their wives, but usually take four. A rich man, "yakhud ketír amra," takes many wives. The Zediyehs eat the wild ass (wáhash), which is common in their hills, but not the tame ass nor the pig.

There are fourteen villages or places in the Jebel, * Compare Layard. 


\section{Bedouin Tribes of the Euphrates. [сн. xv.}

containing two thousand houses, some of stone, some only tents. His own people live principally in tents. He has given me the names of eight springs in the hills: Bárah, Sekiníeh, which flows to the Subbkha Snéyzele, Jiddála, Gabára, Belád, Shingal, Sulahh, which is the Wady Thathar, and Khersi. There are many sorts of fruit-trees grown in the villages-figs, pomegranates, and others, but no palms.

This morning Mátu came to us, he said, to wish us good-bye, he had had news from home, and must be off. "Good news?" we asked._- "Yes, good news." His brother had been attacked by the Sheykh of Sekinieh, but had beaten him off and killed two of his men, and taken their guns and mares. Faris has promised to send some khayál with him, and he loped to carry on the war vigorously with the Sekinins. He wished the Beg to go with him too, and bring his gun. The offer was very tempting, as Samúga is not more than sixty miles from here, and we don't know how much or how little is known of these Zedíyehs, and their religion makes them interesting, and we should certainly accept it but for our engagement with Mr. S.

Mátu started later with fifty of Faris's men under, whom should you think, but our little friend Tellál, as proud as a midshipman in command of his first cutter, and quite unable, in his excitement, to listen to anything we had to say in the way of 
farewells. Wilfrid had a clasp knife he had been intending for Tellál for some time past, and which the boy had coveted. It was now produced, but the young commander was intent on far more important matters, and had already put away from him childish things. He was looking to his spearpoint to see if it was sharp, and to his saddle to see that it was girthed, and could not be distracted. He gave the knife to an old servant to keep till he came back, and, without bidding us good-bye, jumped on his mare, the old retainers hanging about giving him good advice to the last. And so he rode away. He is to collect a tribute which is due from some tribe or village in the Sinjár and, if it is refused, take it by force with his fifty men. He is only twelve years old, but, I will answer for it, he comes back with the booty.

We are now (March 18) becoming anxious for news of Mr. S. It has been arranged between us all along that we are to meet on the 15th, at Deyr, and he was to arrive there if possible a day or two earlier so as to communicate with us, in case he found an opportunity, at Faris's camp. We are already two days behind our time, and still two days' journey from the town, but we know he will make allowance for our want of punctuality, considering how very difficult a march we have had to accomplish. We cannot without appearing unkind to our host, who is now, our friend and brother, propose to leave him without excuse. To-day, how- 
ever, news came from Deyr, through some wandering musicians, that a great personage was expected there from Aleppo; and we have no longer hesitated to mention our wish to depart. Faris, though sorry that we should leave him so soon, has listened to all we had to say in the kindest and most reasonable way, and, seeing that we really were obliged to go, has done all he could to expedite our journey. In spite of his recent interview with Huseyn, and its friendly termination, none of Faris's people can show themselves at Deyr, without danger, except the mollah, whose clerical character gives him a safe conduct. This person, then, has been appointed to accompany us, and at the same time to do a little piece of business for his master in the town.

The mollah is an important functionary here, not that he has any religious duties to perform, for public prayers are unknown among the Bedouins, but, being the only man of liberal education in the camp, he is made use of to read and write all the letters, and to carry on all the diplomatic negotiations which pass between the Sheykh and his neighbours, and this is no small matter, for a great sheykh's life is one of constant business. The present negotiation Faris has shortly explained to us (for since the oath of brotherhood he has no secrets from us). It is that of getting Huseyn to pay up the money due to him for services rendered, and the mollah is to go to Deyr in the character of dun, and do all he can to squeeze the Pasha. It appears that the whole sum promised 
was only sixty pounds, but money is very scarce in the Shammar camp, and the people are clamouring for their share of the mejidies. Not that any one here would call Faris to account for this, only they consider it an insult to their Sheylh that he should be kept waiting for his money, and an injury to themselves to have been made to do the Pasha's business for nothing. "Here we have been," they say, "for a whole month doing the work of zaptichs, and keeping the peace into the bargain, and all balásh."

Faris asked us what we thought he ought to do, and we advised him if he really wanted the money very badly to march down with all his men and encamp just opposite Deyr, and then send in the mollal, but he said he did not wish to quarrel with Huseyn, if he could help it, and would use friendly meaus first, and thought that we might be able to persuade Huseyn for him to do this act of justice. "You see," he said, "the state of our camp here ; the women have no clothes to their backs, and the coffee and sugar are all done. My people are angry and will not put up with this for ever, and, although I shall do my best to keep them quict, they will be down on some of the Pasha's felláhin before long, just to to do themselves justice. And whose fault will it be then?" He requested us also to explain to the Pasha that some recent raids, of which complaint had been made, were no doing of his or his people's, but of his nephews, Míjuel and Eyssa. We asked him if he could affirm on oath to us that this was VOL. I. 
true and he did so, lifting up his hand and repeating "Walláh, Walláh," after the Arab form of oath. We know that the Pasha would not believe him, if he had simply stated the thing to us without swearing.

It seems a pity that so much trouble should be taken for so small a sum, and Wilfrid asked him whether he could not wait for it, or do without it ; but he said there was a tájer, or merchant, now in the camp, to whom he owed ten pounds, and who had come to be paid. We have seen the man about the camp, in appearance something like the Kurd who followed us from Smeyr's, and whom we sent about his business. We had a few more mejidies with us than were necessary for our journey, for travelling here costs almost nothing, and were glad of an opportunity of returning something of the Sheykh's kindness, so we offered to let him have the sum necessary to pay off his Jew; and this, after the hesitation most people make before accepting help of this kind, Faris agreed to. Ten pounds was not a large sum, but he was very grateful, promising to pay it back whenever he should be in funds, and wishing to give Wilfrid a writing for the money. But this Wilfrid, of course, refused, saying that he was a brother, not a tájer. Indeed the Sheykh's word is far better than his bond, and it will interest us afterwards to see whether he remembers this little debt. At present, the mollah has orders to repay it out of any money he may get from the Pasha, but we have told Faris not to put himself out about it, 
and that it will do just as well next year, when, inshallah, we will return to Mesopotamia. He then began to lament that he had no mokhra, filly, or even a colt to give us as a remembrance of him, but that too, he says, shall be ready for us next year. He would not take the rifle or the pistol, which we tried to make him accept, and which he had amused himself so much with. "No," he said, "I am better, as my fathers were, without firearms, and besides I have no mokhra. All I can do for you is this. My people shall make you the raft you will require for crossing the Khábur. They would not do it for the Pasha, or even for the Sultan, for it is felláhin work, fit only for the Jiburi, but they will do it for you, because, you see, you are one of us." It is agreed then that this shall be done next day, and that the mollah shall ride with us into Deyr.

March 19.-We left the Shammar camp at nine o'clock, Faris and a number of his people riding with us to the river bank-those who remained behind wishing us good-bye, and repeating such phrases as, "Our tribe is your tribe, our tents your tents. Come back to us soon, and we will make you tents and give you camels and mares. You shall live with us every winter, and in the summer, when it is hot, you shall have a stone house to retire to at Deyr." The "old man of the mountain," too, as Wilfrid calls Rashid ibn Ali, took an affectionate leave of us, renewing his invitation to Hîyel.

The river Khábur, which is the only tributary 
the Euphrates receives during the whole of its course through the desert, is a considerable stream, and a difficult one to cross. It is about sixty yards wide, has a strong current, and is very deep, - not an interesting river, at least where we saw it directly opposite a mound called Tell Fúddrumi, as it flows. between deep banks of alluvial soil, and has only a thin fringe of brushwood to clothe its nakedness on either side, with here and there a willow struggling. to look like a tree. To one of these a cord had been tied and made fast to a tamarisk root on the opposite bank; and, floating on the water, we saw the most rickety looking thing ever people trusted themselves to on deep water. It was a square raft, made of eight goats' skins blown out to serve as. bladders and tied together with a slight framework of tamarisk boughs. It was at most four feet six inches square, and lay nearly level with the water's. edge. On this we were expected to embark, and I confess that I had no pleasant anticipations of the voyage. But first there was the baggage to be ferried, and the camels and mares to be swum across.

A camel forced to swim is a very ridiculous. object. He hates the water sincerely, and roars and moans piteously when he is obliged to face it. Ours were of course unloaded, and then brought one by one to the river bank. A man on the back and half a dozen others to push behind were needed to get them down the bank, a steep slide of mud, down which the camels went,. with all their legs 
together, souse into the water. The men, who were stripped, then jumped in after them, and, shouting and splashing water in their faces, forced them on, till at last they were out of their depth and everything had disappeared except the camels' noses. Then they seemed to resign themselves, and swam steadily but slowly to the opposite shore, where, fortunately, there was a better landingplace. One of the camels, however, obstinately refused to approach the bank, and, when other means had failed, was thrown down and dragged by the legs into the water, when it at last made up its mind and followed the rest. Once on shore, they all set off, scampering and kicking up their ungainly heels, at full speed, and were with some difficulty got back again by a couple of horsemen. The mares managed it with much less difficulty.

And now our turn was come. Hánna, inspired by the martial company he has been keeping of late with the Shammar, with whom he has become a great favourite from his good humour and his good cooking, insisted upon being the first to cross, and got over without accident. His vehement thanks to Heaven on landing were greeted with shouts of laughter from both sides of the river: for a number of Jiburi, who are encamped beyond it, had come down to help and to see the fun. Faris was in high spirits, keeping up a fire of small chaff at every stage of the proceedings. The Agheyls went next, prudently taking off most of their clothes for fear 


\section{Bedouin Tribes of the Euphrates. [сн. xv.}

of accidents; and then it was our turn. There was an old man who acted as ferryman, and with ourselves and a pile of luggage I thought it more than a load, when, just as we started, in jumped Faris too; and, before we could stop, we were off, our feet dangling through the framework of the raft, and clinging to each other to keep ourselves balanced. As we got to the middle the strain became too great for the old man, who let go the rope; and in an instant we were swept away down the river, without any means of stopping or guiding ourselves, and expecting every moment to upset. But there was no real danger. As soon as they saw what had happened, every Shammar on the bank jumped straight into the water, and we had hardly gone fifty yards before they were around us and guiding us to shore. There we found Hánna, wringing his hands and shedding floods of tears, after his custom, at our loss-a new source of amusement to Faris, who liad never seen a grown man weep before. The mirth, indeed, was so infectious that everybody was agog for fun, and poor fat Ali was made a speedy victim of, and upset in mid-stream amidst roars of laughter. Fatness is a never-ending subject of joke with the Bedouins, who are lean as whipping-posts themselves, and look upon any other condition as a deformity.

And now the time had come when we were to take leave of Faris, for he could go no further with us, as the country between the Khábur and the 
Euphrates is not his district, and the Government lays claim to it for their tame tribes, the Jiburi, Buggára, and others. The moment was almost affecting; for, though we have known him for so few days, he has become our friend and our relation; and who knows if we may ever see him again? He recapitulated to us what we were to say to the Pasha about his affairs; and he again recommended the mollah to take good care of us. Wilfrid pressed him a second time to keep the rifle ; but, though he evidently would have liked it, he persisted in refusing, because he had nothing to give us in its stear. So we promised to send him one from England. Wilfrid's last words to him were a recommendation to keep clear of the towns. "Huseyn," he said, " may be an honourable man and a friend; but he is the servant of the Turks, who killed your father and your brothers, and who some day may find it to their interest to kill you. Stay at home. You have all you want in the Jezíreh, and you are safe there ; and, if you must see the Pashas, let them come out to you in the desert." The mollah, who stood by, heartily joined in this advice, and Faris promised to be wise. Then they, Wilfrid and Faris, kissed each other, such being the custom between Bedouin relations; and we went on our way.*

* We learned afterwards that ho was nearly drowned going back across the Khábur, for the raft upset with him, and somehow got orer his head, but he was pulled out by his people. 


\section{Bedouin Tribes of the Euphrates. [сн. xv.}

We have camped to-night under the Méze, or "Goat Hills," listening to the cry of the owls in a ruined town close by us, and meditating a rush for Deyr to-morrow morning. Mr. S. must have arrived, for Hánna has heard from the Jiburi, or some one, of a great personage with a white beard having arrived at Deyr.

March 20.-Leaving Hánna and Ali and the rest to follow, we have galloped with the mollah to Deyr. From the foot of the hills to the banks of the Euphrates it is an uninterrupted level plain, without a stone and thinly turfed with grass-the perfection of galloping ground;-and we did the distance, forty-two miles, in something under six hours. The sun was scorchingly hot all day, as it has been for a week past, and the mares were pretty well exhausted at the end of their gallop, for they still have their winter coats on, and are only grass fed. Our supply of corn has been long exhausted. Still we held on, stopping every four or five miles for the mollah to overtake us, for his beast was slow, and could not keep ours in sight; and letting our mares feed a few minutes, and then going on again. We passed several camps on our way belonging to the Buggára, where we got milk and lebben, but we ate nothing all day, so as not to suffer from the heat of the sun.

Once we passed through an immense herd of gazelles, many thousands of them, all moving in the same direction-northwards, and we drove one 
lot before us for a mile or two, coming so near them that if Wilfrid had had his gun (he had left it with the baggage) he could have certainly got several, for they were packed together. Then we came upon truffle-hunters, who told us the town was jerib, jerib,-near, just before us. There are three low, isolated hills which mark the direction from Méze to Deyr, called respectively Hejéf-elZorát, Hejẻf-el-Wustáne, and Hejéf-esh-Shamíye, the last being beyond the river.

We were beginning to get wild for news of Europe, and for the letters which we knew Mr. S. would bring us, for we have had none now for three months; and for the delight of telling to one who would appreciate them our adventures, our difficulties, and our successes. The Consul's arrival, too, has become very necessary to us, for the restoration of our credit with the authorities, a credit rather compromised, we fear, by our flight from Bagdad. Then nobody knows who has not experienced it, the delight of talking again in a European language, after having been stumbling on for weeks in Arabic. This thought carried us on without flagging to the end of our ride ; though the last five miles, which were across the lower valley of the Euphrates, in part cultivated, were very severe upon the mares. I doubt if Tamarisk could have gone another mile, and I rode her straight down into the river and let her drink her fill. Poor beasts! they had carried us well. 
346 Bedouin Tribes of the Euphrates. [cur. xv.

The mollah was out of the race, and far behind; and though we waited two hours on the bank for the ferryman, who would not hear our shouts, he did not appear.

This was the hardest part of our day's work, this sitting on the river-bank from one to three o'clock in the sun; and all the time with the knowledge that there was a cool room waiting for us, and perhaps a table spread in the Seraï not half a mile away. Why did not Mr. S. look out of the window and see us there, and move the lubberly ferrymen out of their mid-day sleep to release us? But it was not to be.

At last we got across, and hurried on to the Seraï. The door stood wide open, and the rooms were as we had left them. The Pasha's servants, too, received us with a smile; but it was evident we were not expected. "Where was the Beg, the Consul Beg ?"-_"The Beg returned to Aleppo the day your Excellencies left this house, two months ago, and has not since been seen or heard of." "And the great personage who has arrived in the town?" - "The great personage is Kadderly Pasha, the new Valy of Bagdad, going to join his post."

We have had our long ride for nothing. Mr. S. is not at Deyr!

END OF VOL. I. 





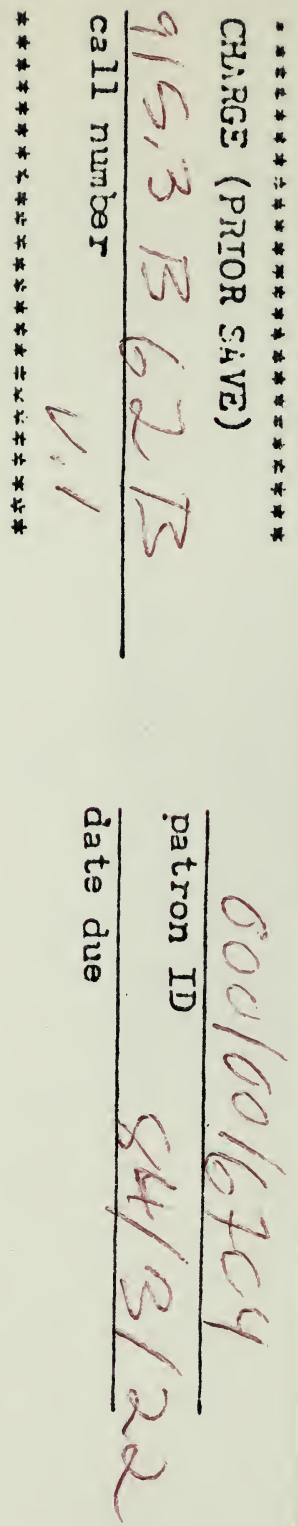


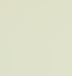

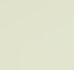
. tan

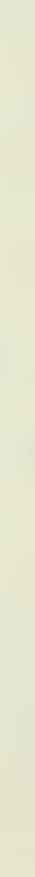


